\title{
The cephalopods of the Boda Limestone, Late Ordovician, of Dalarna, Sweden
}

\author{
Björn KRÖGER \\ Museum für Naturkunde, D-10115 Berlin, Invalidenstrasse 43, Germany. \\ Currently: Museum of Evolution, Uppsala University, Norbyvägen 16, and Department of Earth \\ Sciences Palaeobiology, Villavägen 16, SE 75236 Uppsala, Sweden. \\ E-mail: bjoekroe@gmx.de
}

urn:1sid:zoobank.org:author:72F166B6-51DC-4DD8-9DEE-47EDDEE3D2F2

\begin{abstract}
The late Katian, Late Ordovician Boda Limestone of Dalarna, Sweden contains a rich cephalopod assemblage. The assemblage consists of 61 species, in 31 genera, comprising almost all major Ordovician cephalopod orders. Most common and diverse are the Orthocerida. The Ascocerida are also remarkably common and diverse. The new ascocerid species, Redpathoceras bullatum sp. nov., $R$. depressum sp. nov., $R$. magnum sp. nov., and Probillingsites scandinavicum sp. nov., give reason to revise current hypotheses on the origin and evolution of this group. An ascocerid origin from barrandeoceratids or aspidoceratids is hypothesised. The absence of actinocerids in the Boda Limestone is notable, and is interpreted as an indication of relatively cool and/or deep depositional environments. The dominance of orthocerids is provisionally interpreted as evidence for nutrient-rich waters during the time of the deposition of the Boda Limestone. Additionally, the assemblage contains the new barrandeocerids Schuchertoceras fryi sp. nov., Siljanoceras varians gen. et sp. nov., Warburgoceras gen. nov. (for Cyrtoceras longitudinale Angelin in Angelin \& Lindström, 1880), the new endocerid Cameroceras turrisoides sp. nov., the new oncocerid Cyrtorizoceras thorslundi sp. nov., and the new orthocerids Dawsonoceras stumburi sp. nov., Isorthoceras angelini sp. nov., I. curvilineatum sp. nov., Nathorstoceras adnatum gen. et sp. nov., N. kallholnense gen. et sp. nov., Palaeodawsonocerina? nicolletoides sp. nov., Pleurorthoceras osmundsbergense sp. nov., and Striatocycloceras isbergi sp. nov.
\end{abstract}

Key words. Katian, Baltoscandia, Nautiloidea, Ascocerida.

Kröger B. 2013. The cephalopods of the Boda Limestone, Late Ordovician, of Dalarna, Sweden. European Journal of Taxonomy 41: 1-110. http://dx.doi.org/10.5852/ejt.2013.41

\section{Introduction}

The Boda Limestone comprises geographically limited occurrences of massive carbonate bodies in the Siljan district of Dalarna, Sweden that are of late Katian to Hirnantian (Late Ordovician) age. The limestones represent large, up to $150 \mathrm{~m}$ thick and $1000 \mathrm{~m}$ wide isolated fossil reefs. The processes responsible for the formation of the reefs, and the physico-chemical conditions of their depositional environment remain poorly known, but a consensus exists that assumes that the time at which these 
structures were formed represents an episode of relatively cool climate - the so called Boda Event (Cherns \& Wheeley 2007, 2009; Ainsaar et al. 2010). The general absence of frame builders, such as stromatoporoids, and the omnipresence of large stromatactis structures in the micritic core facies make the Boda reefs textbook examples of carbonate mud mounds (Jaanusson 1982; Suzuki \& Bergström 1999; Suzuki 2002; Suzuki et al. 2009; see Riding 2002 for a definition of a "carbonate mud mound" and "reef"). Large horizontal and vertical crevices and caves form so called "pockets", filled with syndepositional conglomerates and a rich fauna of cave dwellers and concentrated shells (e.g., Suzuki 2002; Rasmussen et al. 2010).

Generally the fauna of the Boda Limestone is highly endemic and very diverse, with more than 90 species of trilobites and more than 100 species of brachiopods described (see review in Ebbestad \& Högström 2007). The best known are the trilobites (e.g., Warburg 1925), brachiopods (e.g., Cocks 2005; Rasmussen et al. 2010) and bivalves (Isberg 1934). Other groups from the Boda Limestone are inadequately known taxonomically and include gastropods, echinoderms, and bryozoans. All are in need of revision. Herein, for the first time a complete description of the cephalopod assemblage is presented.

As cephalopods were the top predators in the Late Ordovician, their taxonomic composition, richness and body size distribution will contribute essential data for understanding the Boda ecosystem and may help to elucidate the conditions under which the mounds formed.

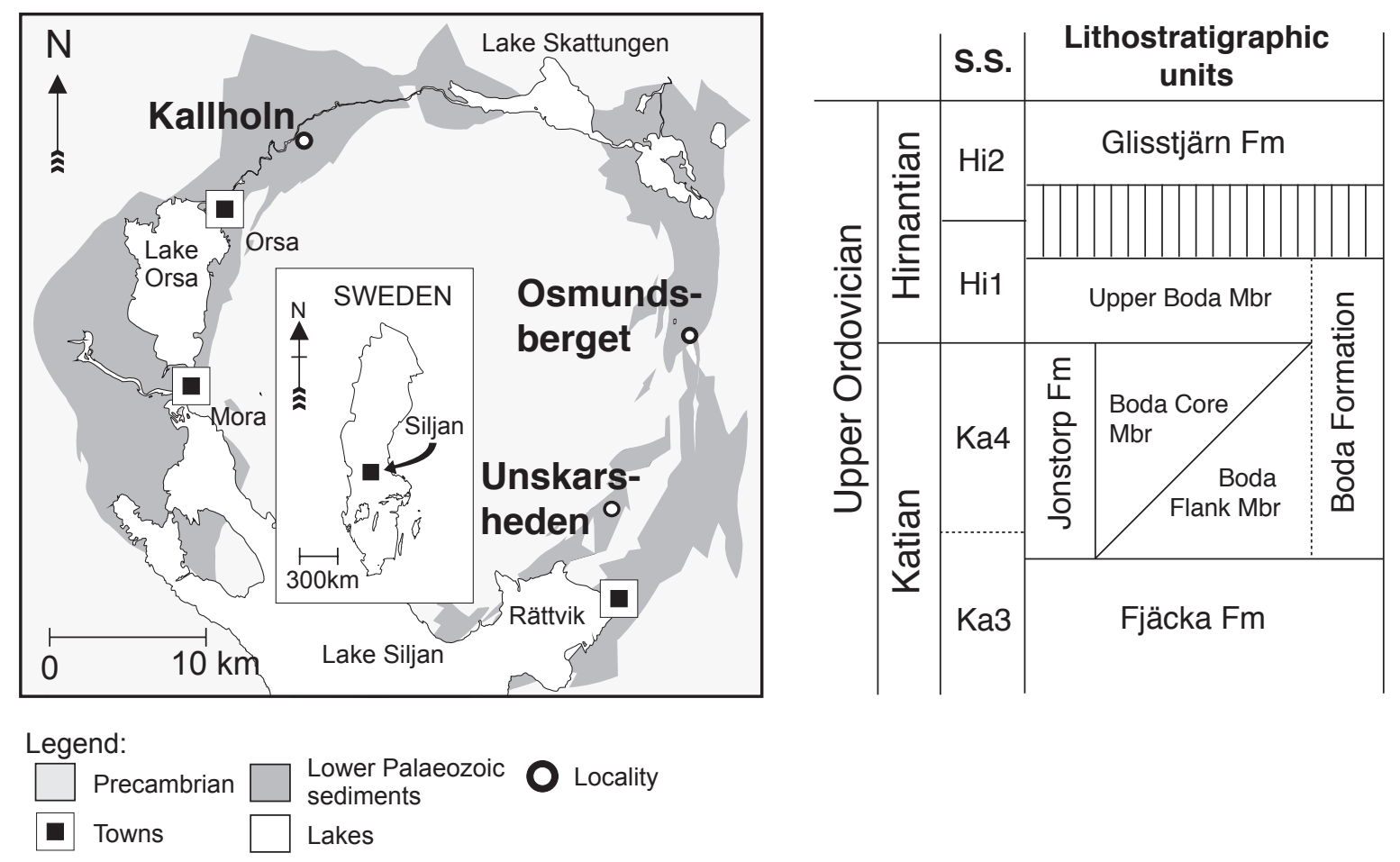

Fig. 1. Map of the Siljan ring structure with Lower Palaeozoic sediments preserved (dark grey), and the three most important localities are marked (modified from Ebbestad \& Högström 2007). Stratigraphical scheme of the Boda Limestone and adjacent lithostratigraphic units (compiled from Suzuki et al. 2009; Rasmussen et al. 2010). Abbreviations: Fm = Formation; Mbr = Member; S.S. $=$ stage slices (after Bergström et al. 2009). 
Cephalopod fossils have been collected from the Boda Limestone for generations, and the Naturhistorisk Riksmuseet, Stockholm, Sweden (NRM) and Evolutionsmuseet of the Uppsala University, Uppsala, Sweden (PMU) hold hundreds of specimens from most of the important Boda Limestone sites. Selected cephalopod taxa of the Boda Limestone were reported by Angelin \& Lindström (1880), who described five species, and Frye $(1982,1987)$, who described a number of ascocerids, oncocerids and coiled forms. Niko (2008) described a single orthoconic species. A complete monographic description of the museum material has never been provided. The work presented herein is the first attempt at a monographic review of the cephalopod assemblage of the Boda Limestone.

This review of the Boda Limestone cephalopods will provide the basis of a comprehensive stratigraphical, palaeobiogeographical, and palaeoecological analysis of the assemblages. The primary aim of this paper is to provide a complete list of cephalopod occurrences from the Boda Limestone for the first time.

The Boda cephalopods are particularly rich in a specific group, the Ascocerida. New ascocerid species and their features, described herein, provide a new perspective on the origin and evolution of this group.

\section{Geological setting}

The Boda Limestone occurs in more than 20 more or less isolated geological bodies around the Siljan impact structure, Dalarna, Sweden (see, e.g., Thorslund 1936; Ebbestad \& Högström 2007). The Siljan impact structure is an almost circular geological structure with a diameter of ca. $75 \mathrm{~km}$ (Fig. 1). The structure is interpreted as the consequence of a mid Devonian meteorite impact (Reimold et al. 2005). The resulting prominent ring graben of the impact prevented Lower Palaeozoic sediments from subsequent erosion. The Palaeozoic rocks in the ring graben are tectonically disturbed, often dipping strongly, locally fractured, and sometimes folded. Nevertheless, the Ordovician succession is remarkably complete and diagenetically little altered (see review in Ebbestad \& Högström 2007).

The stratigraphic succession of the Ordovician of the Siljan district has been studied for more than 150 years. A review of the most important Late Ordovician units was published by Ebbestad \& Högström (2007). The faunal content, facies architecture and chemostratigraphical analyses indicate a late KatianHirnantian age of the Boda Limestone (review in Ebbestad \& Högström 2007; Suzuki et al. 2009; Rasmussen et al. 2010).

The Boda Limestone is composed of a late Katian, Boda Core Member (the mound core facies), which is capped by the Hirnantian Upper Boda Member that undergoes lateral transition to the Boda Flank Member (Suzuki et al. 2009; Rasmussen et al. 2010; Fig. 1). The Boda Core Member and the Boda Flank Member of the Boda Limestone are stratigraphically equivalent to the Johnstorp Formation (Suzuki et al. 2009). Locally, the Boda Core Member is overlain unconformably by the late Hirnantian Glisstjärn Formation (Rasmussen et al. 2010; Kröger et al. 2011). Often large and complex pockets are preserved within the Boda Core Member (see, e.g., Suzuki 2002). The exact stratigraphy of the individual pockets is often difficult to evaluate, but generally the fillings can be regarded as syndepositional with the Boda Core Member or the Upper Boda Member (Suzuki et al. 2009, Rasmussen et al. 2010).

\section{Material and Methods}

Fossils have been collected and described from the Boda Limestone for nearly two centuries (see Ebbestad \& Högström 2007 for a review). Historically, the reefs of the Kullsberg and the Boda limestones of Dalarna are well exposed on small hills and ridges (Warburg 1910). Intensive quarrying since the beginning of the $20^{\text {th }}$ Century created new opportunities for stratigraphical, geological and 
paleontological investigations and comprehensive collections have been accumulated since then (see review in Thorslund 1936). The greatest portion of the collections of the Boda Limestone in the NRM and PMU are mainly the result of the many field excursions carried out by Elsa Warburg (1886-1953) during the first two decades of the $20^{\text {th }}$ Century to the limestone quarries of the Siljan district. The collections amassed a total of more than 500 cephalopod specimens. In almost all cases, the specimens are labelled with a collection date and a locality such as "Osmundsberget" or "Kallholn", but with no detailed stratigraphical or locality information (for a detailed listing of the collection localities see Table 1). The approximate stratigraphical position can be deduced from the matrix lithologies in most specimens. Two lithologies can be distinguished: (a) a massive whitish wackestone or wackestoneconglomerate with brownish to reddish mollusk shells, and (b) a pale grey to brownish wackestone, which is often heavily fractured. The lithologies are interpreted respectively as representing (a) the latest Katian Boda Core Member and contemporaneous void fillings and pockets, and (b) the Hirnantian Upper Boda Member (see Suzuki et al. 2009).

The preservation of shelly material is exceedingly good, with minute details of ornamentation and even color marks occasionally preserved. However, all cephalopod shells are recrystallised and shell structures are generally poorly preserved. Often the chambers of the phragmocones are partially empty or filled with sparite. In one case the chambers are filled with a sequence of a yellowish layered micritic limestone with bird's eye structures covered with an ostracod coquina (Fig. 2). A similar concentration of tiny smooth ostracods in stromatactis cavities of the Boda core facies is reported by Suzuki \&
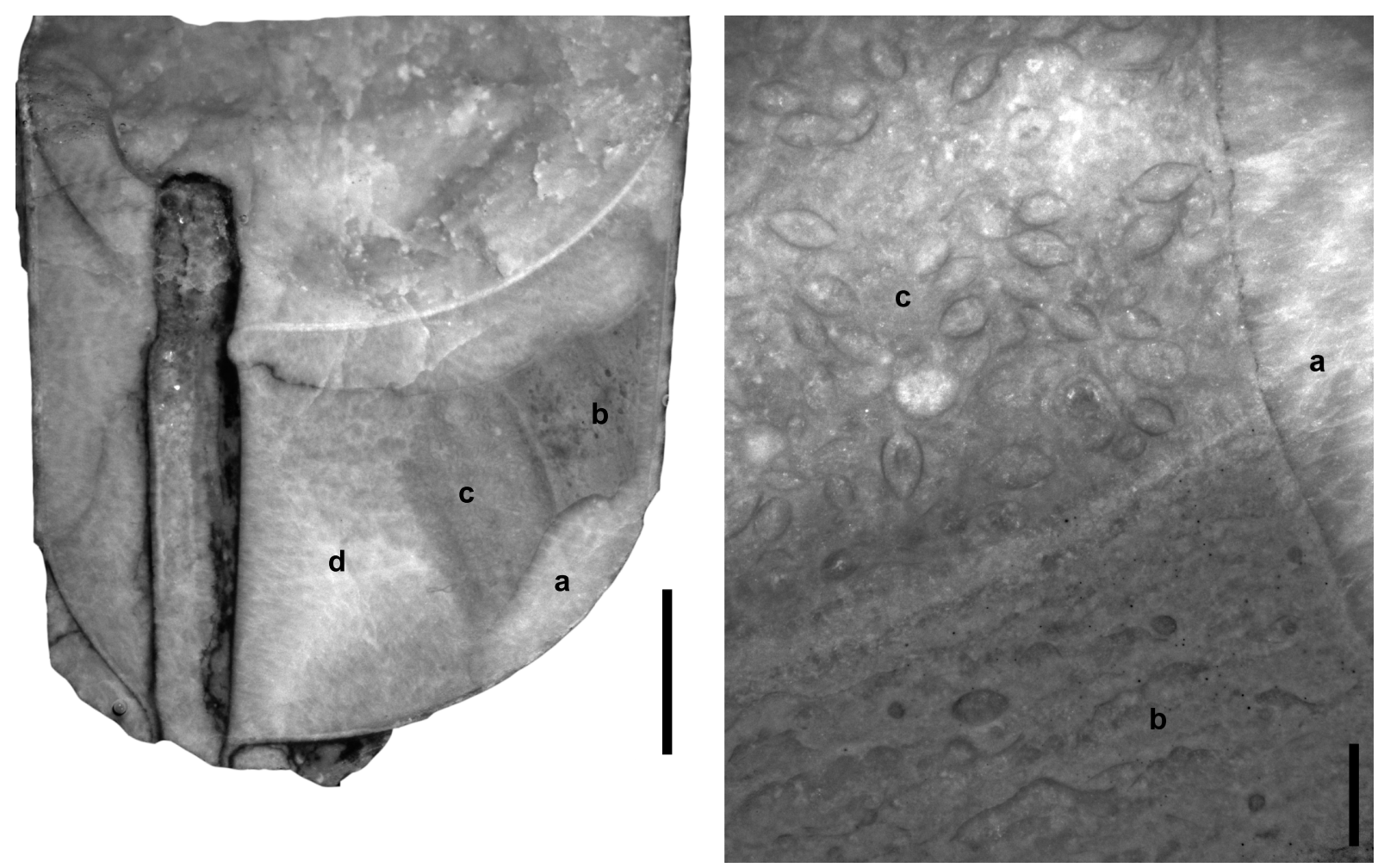

Fig. 2. Polished median section of a fragment of a phragmocone of Geisonoceras wegelini (Angelin in Angelin \& Lindström, 1880) comb. nov., PMU 26747, Unskarsheden. The chamber is filled with epiand hypsoseptal deposits (a), a layered wackestone with bird's eye structures (b), a concentration of ostracods (c) and a sparitic space (d). Picture on the right is detail of picture on the left. Left scale $=10$ $\mathrm{mm}$, right scale $=1 \mathrm{~mm}$. 
Table 1. List of localities of Boda Limestone cephalopods with relevant references to detailed locality descriptions.

\begin{tabular}{|c|c|c|c|c|}
\hline $\mathrm{Nr}$ & Locality & Coordinates $\left({ }^{\circ} \mathrm{N},{ }^{\circ} \mathrm{E}\right)$ & Lithostratigraphy & Important references \\
\hline 1 & Kallholn quarry & $\begin{array}{l}61.167071 \\
14.712925\end{array}$ & Boda Limestone & $\begin{array}{l}\text { Isberg (1934: fig. 1.1); Thorslund (1936: 51, fig. 14); Suzuki et } \\
\text { al. (2009: fig. 1) }\end{array}$ \\
\hline 2 & $\begin{array}{l}\text { Osmundsberget } \\
\text { quarry }\end{array}$ & $\begin{array}{l}61.049173 \\
15.200615\end{array}$ & Boda Limestone & $\begin{array}{l}\text { Isberg (1934: fig. 1.7); Thorslund (1936: 46, figs 21-22); } \\
\text { Jaanusson (1982: 35, fig. 4); Ebbestad \& Högström (2007: 52, } \\
\text { fig. 53); Suzuki et al. (2009: fig. 1) }\end{array}$ \\
\hline 3 & $\begin{array}{l}\text { Unskarsheden } \\
\text { quarry }\end{array}$ & $\begin{array}{l}60.948626 \\
15.103948\end{array}$ & Boda Limestone & Isberg (1934: fig. 1.21), Thorslund (1936: 37) \\
\hline 4 & Rättvik & $\begin{array}{l}60.895269 \\
15.109978\end{array}$ & Boda Limestone & Warburg (1910: 433, pl. 14) \\
\hline 5 & Skålberget & $\begin{array}{l}60.943183 \\
15.096588\end{array}$ & Boda Limestone & $\begin{array}{l}\text { Isberg (1934: fig. 1.21); Thorslund (1936: 37, fig. 14); } \\
\text { Jaanusson (1982: 29, figs 2-3) }\end{array}$ \\
\hline 6 & Östbjörka & $\begin{array}{l}60.977951 \\
15.137615\end{array}$ & Boda Limestone & Isberg (1934: fig. 1.22); Thorslund (1936: 38, fig. 16) \\
\hline 7 & Amtjärn & $\begin{array}{l}60.937079 \\
15.076225\end{array}$ & $\begin{array}{l}\text { Johnstorp } \\
\text { Formation }\end{array}$ & $\begin{array}{l}\text { Bergström (2007: 37, fig. 9); Ebbestad \& Högström (2007: 52, } \\
\text { fig. 53) }\end{array}$ \\
\hline 8 & Jutjärn & $\begin{array}{l}60.983085 \\
15.249453\end{array}$ & Boda Limestone & $\begin{array}{l}\text { Thorslund (1936: 41); Suzuki \& Bergström (1999: fig. 1); } \\
\text { Ebbestad \& Högström (2007: 58); Suzuki et al. (2009: fig. 1) }\end{array}$ \\
\hline
\end{tabular}

Bergström (1999) and Ebbestad \& Högström (2007). Most of the shells are slightly fragmented, partially broken or slightly deformed as a result of the mid Devonian bolide impact, but no evidence of repeated syndepositional reworking or prolonged exposure or extensive bioerosion is apparent. Therefore, the material is interpreted as an autochthonous assemblage representative of the original habitat.

All measurements were taken using vernier calipers or a calibrated graticule inserted into one eyepiece of a binocular microscope. Unless otherwise indicated, the specimens were coated with ammonium chloride and then photographed. Polished median sections of selected specimens were prepared and photographed. Photographs were made with a Leica MZ 9.5 stereo microscope and a Nikon DS-Fi1 camera enhanced by Nikon's NiS Elements software.

Three descriptive indices are used: The whorl expansion rate (WER) adopted from Korn \& Klug (2003) is used for the description of coiled specimens. The whorl expansion rate is calculated as WER = $\left(\mathrm{d}_{\mathrm{ml}} / \mathrm{d}_{\mathrm{ms}}\right)^{2}$ where $\mathrm{d}_{\mathrm{ml}}$ is the diameter of the conch and $\mathrm{d}_{\mathrm{ms}}$ the diameter $360^{\circ}$ preceeding $\mathrm{d}_{\mathrm{ml}}$. The whorl width index (WWI) is the whorl width divided by the whorl height. The siphuncular position ratio (SPR) is adopted from Frey (1995) and is calculated as the minimum distance of the connecting ring from the conch margin divided by the corresponding conch height.

The descriptive terms cyrtochoanitic and suborthochoanitic are often deliberately used; here "orthochoanitic" is used strictly when the angle of the septal neck is nearly 90 degrees; "suborthochoanitic" is used when it is 90-180 degrees; and "cyrtochoanitic" when it is more than 180 degrees. This strict usage in some cases causes deviations from original species or genus diagnoses, which are not evaluated as diagnosis emendations, because they regard the terminology only and not the diagnostic characters themselves. 


\section{Results}

Phylum Mollusca Linnaeus, 1758

Class Cephalopoda Cuvier, 1797

Order Endocerida Hyatt in Zittel, 1900

Family Endoceratidae Hyatt, 1884

Genus Cameroceras Conrad, 1842

\section{Type species}

Cameroceras trentonense Conrad, 1842, Middleville, New York, USA, Trenton Limestone, late Katian; by original designation.

\section{Diagnosis}

Slender, large orthocones with circular or somewhat depressed cross section; sutures simple and straight, or with very slight ventral lobe; siphuncle up to 0.5 of corresponding conch cross section in diameter; mostly marginally positioned; septal necks holochoanitic; endocones simple; endosiphuncular tube narrow, situated in half of siphuncle that is closer to conch margin. (Adopted from Teichert, 1964.)

\section{Cameroceras hasta (Eichwald, 1857)}

Fig. 3

Endoceras hasta Eichwald, 1857: 194.

Rossicoceras pirguense Balashov, 1968: 113, pl. 15, figs 3, 4.

Endoceras hasta - Eichwald 1860: 1247, pl. 46, fig. 7a-b.

Endoceras megastoma - Teichert 1930: 270, 273, pl. 5, fig. 1, text-fig. 2 (with synonymy).

Rossicoceras hasta - Balashov 1962: pl. 4, fig. 4; 1968: 112, pl. 15, figs 1, 2; 1974: 794, pl. 4, fig. 4. Saladzius 1966: 36, pl. 6, fig. 2. — Dzik 1984: 35, text-fig. 7.32.

\section{Diagnosis}

Smooth orthocones with a slightly depressed conch cross section; angle of expansion less than $5^{\circ}$; sutures directly transverse, ca. seven chambers occur on a distance similar to the conch cross section; siphuncular diameter ca. 0.5 of corresponding conch cross section; siphuncle slightly removed from
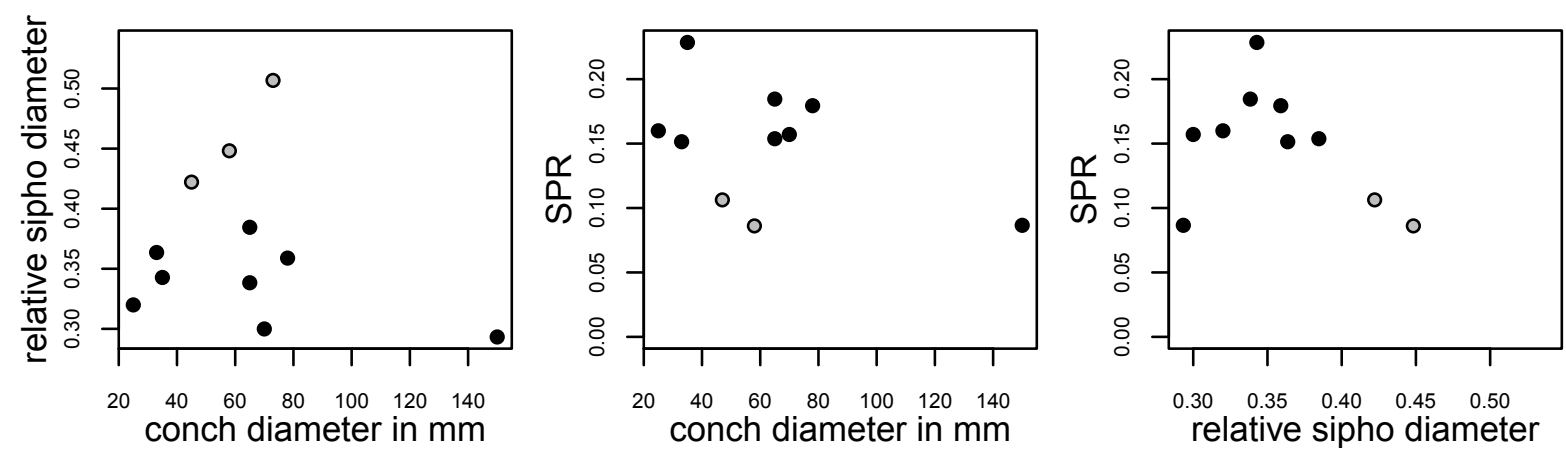

Fig. 3. Variation in relative siphuncle size, position and angle of expansion in Cameroceras hasta (Eichwald, 1860) (grey points) and Cameroceras turrisoides sp. nov. SPR $=$ the minimum distance of the connecting ring from the conch margin, divided by the corresponding conch height. 
conch wall with SPR of 0.1; siphuncular segments slightly concave in longitudinal view; septal necks holochoanitic; endosiphocones form central spiculum (compiled from Balashov 1968).

\section{Type locality and horizon}

Saaremõisa, western Estonia, Vormsi Regional Stage, late Katian Ordovician.

\section{Material examined}

Four specimens (PMU 26609-26612) from Kallholn, Dalarna, Boda Limestone; late Katian, Late Ordovician.

\section{Description}

This species was described in detail by Teichert (1930) and Balashov (1968). The specimen from the Boda Limestone adds some detail with regard to the variability of some characters. The chamber height in the four measured specimens varies from ca. 0.1 to 0.2 of the corresponding conch cross section, the siphuncular diameter varies from 0.42 to 0.5 , and the distance of the siphuncle from the conch margin is $0.09-0.11$ of the corresponding conch cross section (Fig. 3). In specimen PMU 26611, parts of the external shell are preserved, but the preservation is relatively poor and no ornamentation is visible on the surface.

\section{Remarks}

Balashov (1968) distinguished R. pirguense from R. hasta mainly on the position of the siphuncle, which should be closer to the conch margin in $R$. pirguense. However, the information given in the original species description is ambiguous. The measurements provided in the text (Balashov 1968: 113) reveal a relative distance which is nearly identical to that of $R$. hasta. Based on these measurements and the original figures, $R$. hasta and $R$. pirguense are indistinguishable and $R$. pirguense must be regarded as a junior synonym of $R$. hasta.

\section{Comparison}

Cameroceras turrisoides sp. nov. differs from this species in having a narrower siphuncle (ca. 0.3-0.4 of the corresponding conch cross section) and a siphuncle which is closer to the conch center (SPR ca. 0.2 ; Fig. 3).

Cameroceras regulus (Eichwald, 1860) from the Vormsi Regional stage of Estonia differs in having a slightly larger siphuncle ( 0.5 of conch cross section) in contact with the conch margin. Endoceras coxi Foerste \& Cox, 1936, from the latest Katian of Akpatok Island of the Canadian Arctic, is similar to $C$. hasta with respect to the relative diameter of the siphuncle and the relative distance of the siphuncle from the conch margin. Consequently, this species must be assigned within Cameroceras. The chamber spacing of Cameroceras coxi (Foerste \& Cox, 1936) comb. nov. (ca. 3.6 chambers in a distance corresponding to the conch diameter) is not within the range of variance of C. hasta.

\section{Stratigraphic and geographic range}

Vormsi and Pirgu Regional Stage, Estonia, Lithuania (Saladzius 1966; Balashov 1968), late Katian, Taymyr, Russia (Balashov 1968); Boda Limestone, late Katian, Siljan District, Sweden.

Cameroceras regulus (Eichwald, 1860)

Endoceras regulus Eichwald, 1857: 177.

Orthoceras turris Angelin in Angelin \& Lindström, 1880: 6, pl. 6, figs 14, 15.

Endoceras iucundum Stumbur, 1956: 182, pl. 25, text-fig. 3, pl. 1, figs 4, 7, 8, pl. 2, figs 1, 3. 
Endoceras regulus - Eichwald 1860:1248, pl. 46, fig. 8.

Cameroceras regulus - Balashov 1968: 70, 101, pl. 5, fig. 3.

\section{Diagnosis}

Orthocones with a slightly depressed conch cross section; angle of expansion less than $5^{\circ}$; ornamented with fine transverse striae; sutures directly transverse, ca. seven chambers occur on a distance similar to the conch cross section; siphuncular diameter up to 0.5 of corresponding conch cross section; siphuncle marginal, in contact with shell wall; siphuncular segments slightly concave in longitudinal view; septal necks holochoanitic. (Adopted from Balashov 1968.)

\section{Type locality and horizon}

Kõrgesaare, Hiiumaa Island, Estonia; Vormsi Regional Stage, late Katian, Ordovician.

\section{Material examined}

One specimen (NRM Mo 152350) from Ostbjörka, Dalarna, Boda Limestone; late Katian, Late Ordovician.

\section{Description}

The specimen is a portion of a phragmocone with a diameter of $72 \mathrm{~mm}$ and marginally positioned siphuncle $31 \mathrm{~mm}$ in diameter (ca. 0.43 of the corresponding conch cross section). Directly transverse septa are $18 \mathrm{~mm}$ apart ( 0.25 of the conch cross section). The conch surface is ornamented with irregularly spaced, widely rounded striae, and in parts a faint, narrowly spaced shallow longitudinal striation is also visible.

\section{Remarks}

The specimen described herein was first described and figured as Orthoceras turris Angelin in Angelin \& Lindström, 1880; it is the only known specimen of this species. The specimen agrees in general conch shape and in ornamentation with $C$. regulus. The species $C$. regulus is based on a type from the Vormsi Formation, in which the shell preservation is poor compared with that of the Boda Limestone and faint details of the ornamentation are not preserved. Therefore, the faint longitudinal striation found in the specimen from the Boda Limestone is regarded here as a character that does not justify the distinction of two species, and $O$. turris is interpreted as a junior synonym of $C$. regulus.

\section{Comparison}

Endoceras landerense Foerste, 1935 is comparable to Cameroceras regulus with respect to the angle of expansion, chamber height and position and relative diameter of the siphuncle, but the details of the ornamentation of this species are not known.

\section{Stratigraphic and geographic range}

Vormsi Regional Stage, Estonia (Balashov 1968), late Katian; Boda Limestone, late Katian, Siljan District, Sweden.

Cameroceras turrisoides sp. nov. urn:1sid:zoobank.org:act:3166A3D0-2EBC-40C4-AEF2-F6DFF3152F30

Figs 4A, 5, 6, 7D

Endoceras sp. B. - Strand 1934: 10.

Cameroceras sp. - Evans 1994: 16, fig. 6.1-2 (non fig. 6.3). 


\section{Diagnosis}

Slender orthocones with average angle of expansion of ca. $6^{\circ}$, elliptical conch cross section, which is slightly compressed in earlier growth stages and slightly depressed in late growth stages; ornamented with irregularly spaced lirae, which are slightly oblique, shifted toward the apex on the prosiphuncular side and forming very shallow, broad hyponomic sinus; additionally shell is slightly irregularly undulated; sutures directly transverse, with distance (cameral depth) varying from 0.17 to 0.3 of the corresponding conch cross section; siphuncle eccentric with SPR of ca. 0.2 ; siphuncle diameter relatively small with 0.3-0.4 of the corresponding conch cross section; siphuncular segments slightly concave in longitudinal section, septal necks holochoanitic; apex large with angle of expansion of ca. $25^{\circ}$, a length of ca. $50 \mathrm{~mm}$ and a conch height of $24 \mathrm{~mm}$, apically slightly curved with siphuncle on concave side of conch curvature.

\section{Etymology}

Refers to the similarity of this species to the type of Orthoceras turris Angelin in Angelin \& Lindström, 1880 , which differs in having a marginal, slightly wider siphuncle.

\section{Type material}

\section{Holotype}

PMU 26613.
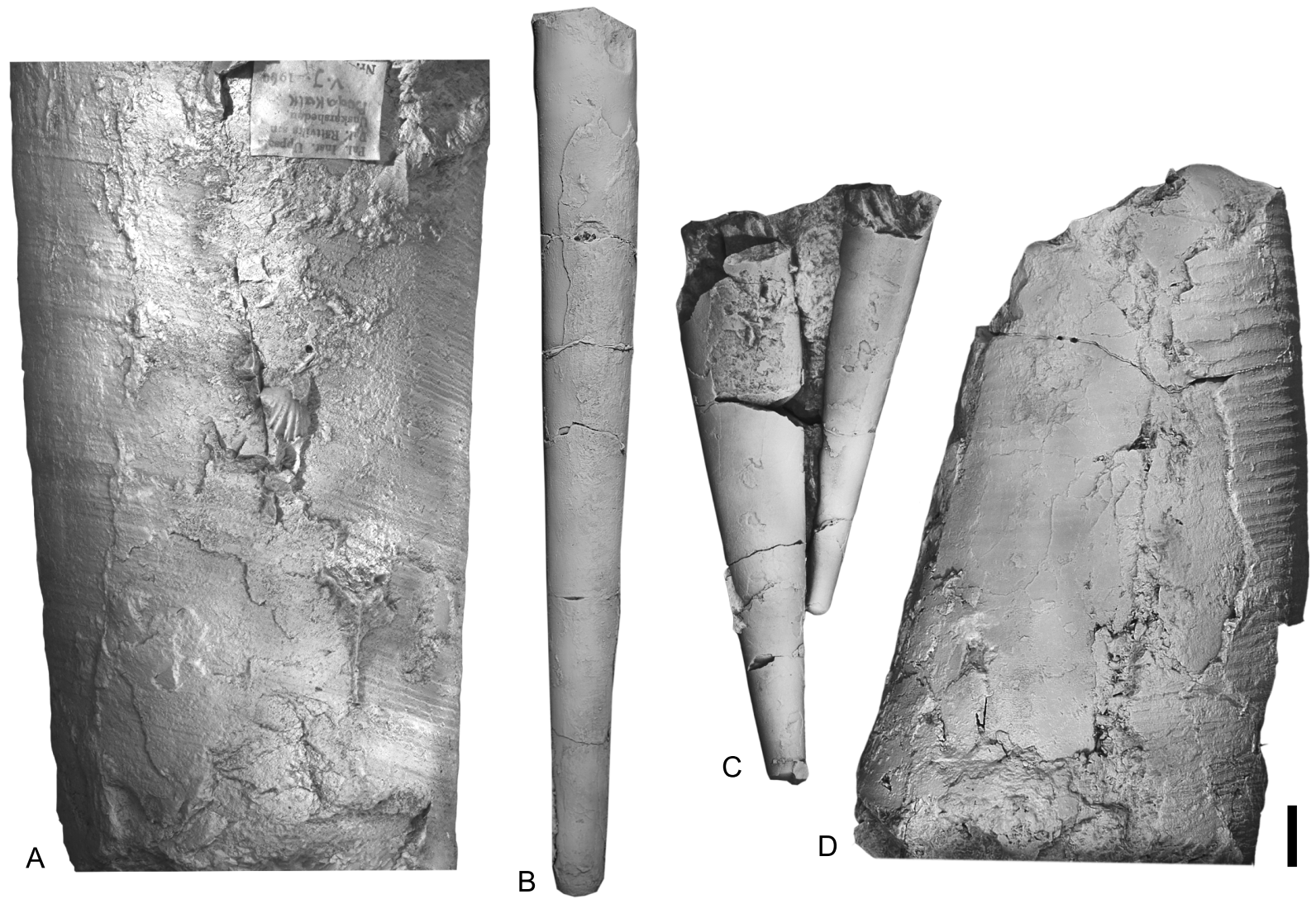

Fig. 4. Orthoconic cephalopods of the Boda Limestone. A. Cameroceras turrisoides sp. nov., PMU 26613, holotype, Unskarsheden, lateral view. B. Isorthoceras dalecarlense Kröger et al., 2011, PMU 26794, Kallholn. C. Isorthoceras wahlenbergi Niko, 2008, PMU 26893 and 26894, Kallholn. D. Order, gen. et sp. indet., PMU 26950, Kallholn, lateral view. Scale bar $=10 \mathrm{~mm}$ for all figures. 


\section{Paratypes}

Fourteen additional specimens (paratypes): seven (PMU 26614-26620, NRM Mo 9264) from Kallholn; three (PMU 26621-26623) from Osmundsberget; and four (PMU 26624-26627) from Unskarsheden, Dalarna, Sweden, Boda Limestone, Boda Core Member, late Katian.

\section{Type locality and horizon}

Unskarsheden, Dalarna, Sweden, Boda Limestone, Boda Core Member, late Katian, Ordovician.

\section{Description}

The holotype is a fragment of a phragmocone with a length of $128 \mathrm{~mm}$, a conch height of $63-77 \mathrm{~mm}$, and a conch width of 68-81 mm (width/height ratio ca. 1.05-1.08, and angle of expansion in width of ca. $2.2^{\circ}$; Fig. 4A). The cross section is elliptical. The surface of the conch is ornamented with irregularly spaced oblique, shallow lirae. Between the lirae are widely rounded, shallow valleys. The ornamentation is slightly oblique, forming a shallow broad hyponomic sinus on the prosiphuncular side of the conch. The siphuncle of the holotype is circular in cross section with a diameter of $26-31 \mathrm{~mm}$ (ca. $0.4 \mathrm{of}$ conch cross section) and eccentrically positioned with a distance of 10-12 mm from conch margin (SPR ca. $0.16)$.

A total of 12 measurements reveals a varying angle of expansion with a mean of $5.7^{\circ}$, and a maximum of $8.8^{\circ}$, without any clear ontogenetic trend, but highest angles occur in intermediate conch sizes (Fig. 3). The chamber distance was measured in five specimens and varies between 0.13 and 0.33 of the corresponding conch cross section without any significant ontogenetic trend. The diameter of the siphuncle varies between ca. 0.3 and 0.4 relative to the corresponding conch cross section diameter. In general, the initial position of the siphuncle is nearly marginal, but during ontogeny shifts toward the conch axis so that the SPR lies between ca. 0.15 and 0.18. However, in the largest specimen in
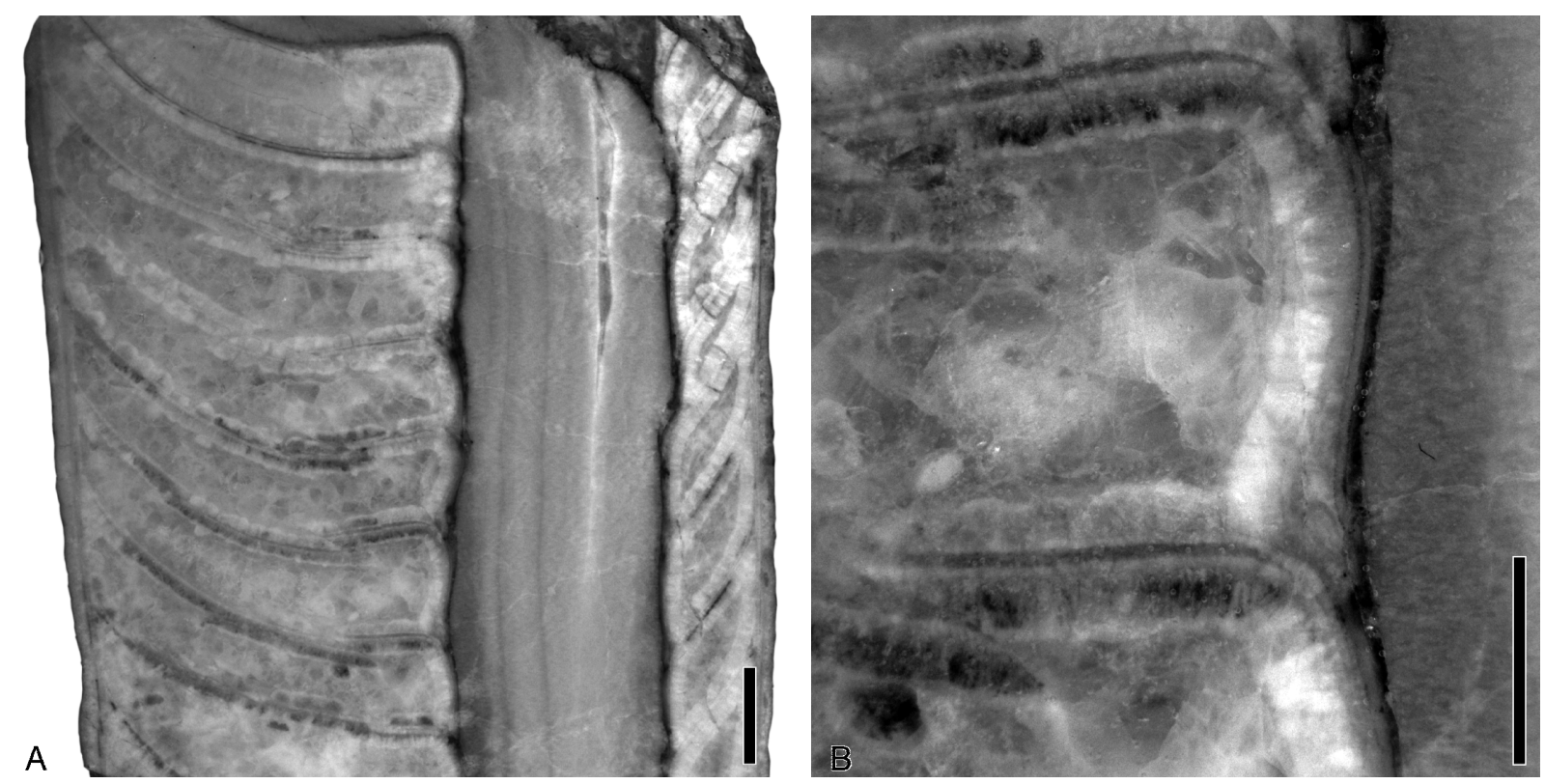

Fig. 5. Polished median section of Cameroceras turrisoides sp. nov., PMU 26624, Unskarsheden, Boda Limestone. A. Total fragment; note that the light, layered, micritic filling of the siphuncle is not an endosiphuncular deposit. B. Enlarged detail of the connecting ring and the holochoanitic septal neck. Scale bars: $A=10 \mathrm{~mm} ; \mathrm{B}=5 \mathrm{~mm}$. 
the collection (PMU 26627), a portion of phragmocone has a maximum diameter of $165 \mathrm{~mm}$ and a siphuncle diameter approximately 0.3 of the conch height, and the SPR is only 0.09 .

The structure of the siphuncle can be seen in specimen PMU 26624, a piece of phragmocone with a diameter of 75-81 mm (Fig. 5). The septal distance varies between 8 and $14 \mathrm{~mm}$ (nine chambers occur in a distance of $97 \mathrm{~mm}$ ). The septal necks are holochoanitic with a concave to s-shaped profile.

The collection includes two specimens representing apical portions (PMU 26623, NRM Mo 9264) with completely preserved shells (Figs 6, 7). Both specimens possess large conical apical parts (maximum diameters ca. $25 \mathrm{~mm}$ ) that differ significantly from the younger growth stages. This apical portion of the
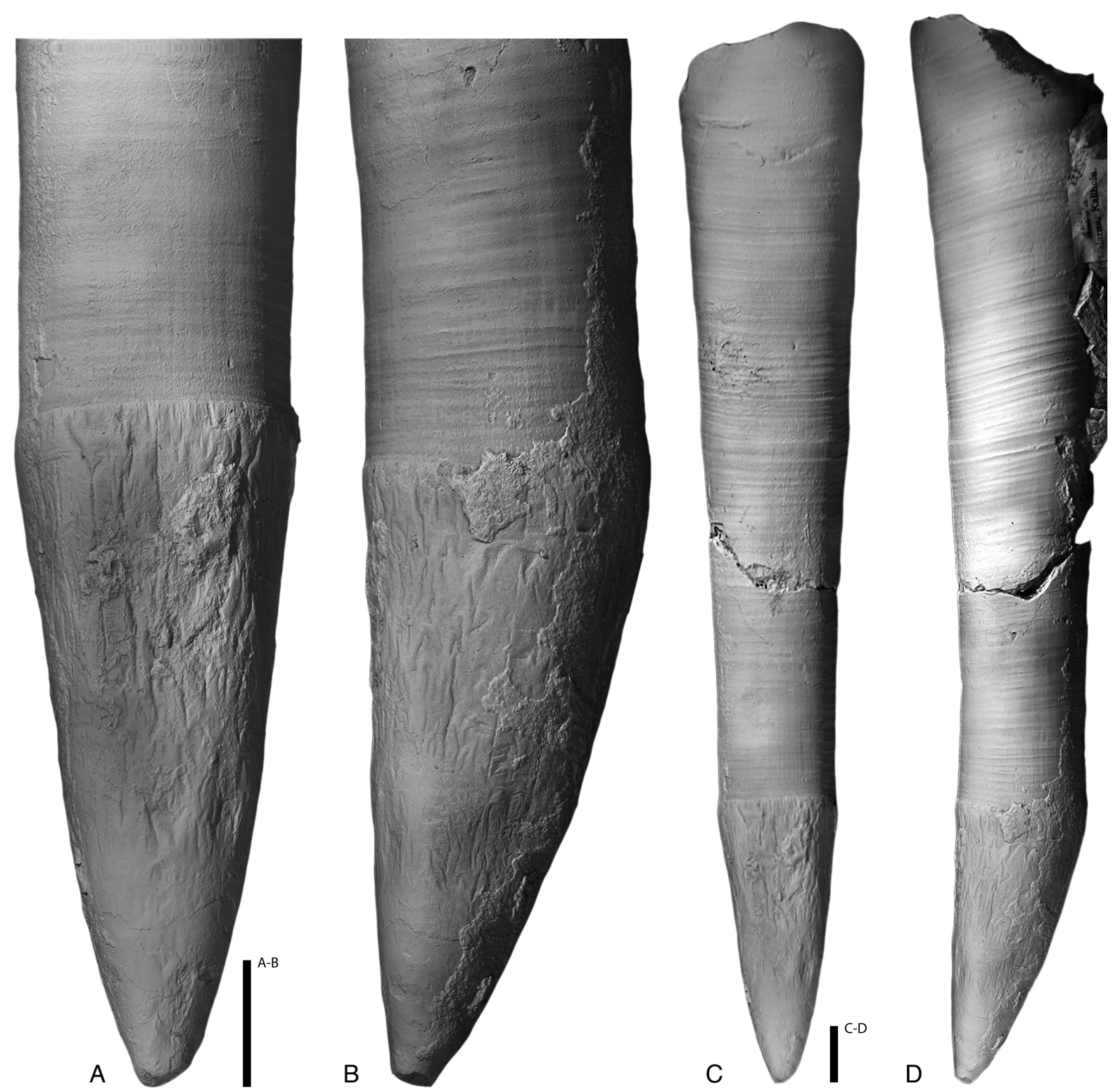

Fig. 6. Apex of Cameroceras turrisoides sp. nov., NRM-PZ Mo 9264, Kallholn, Boda Limestone. A. View from prosiphuncular side. B. Lateral view. C. Complete specimen, prosiphuncular view; note shell repair on adoral part. D. Lateral view. Scale bars: A-B $=10 \mathrm{~mm}$; C-D $=10 \mathrm{~mm}$. 

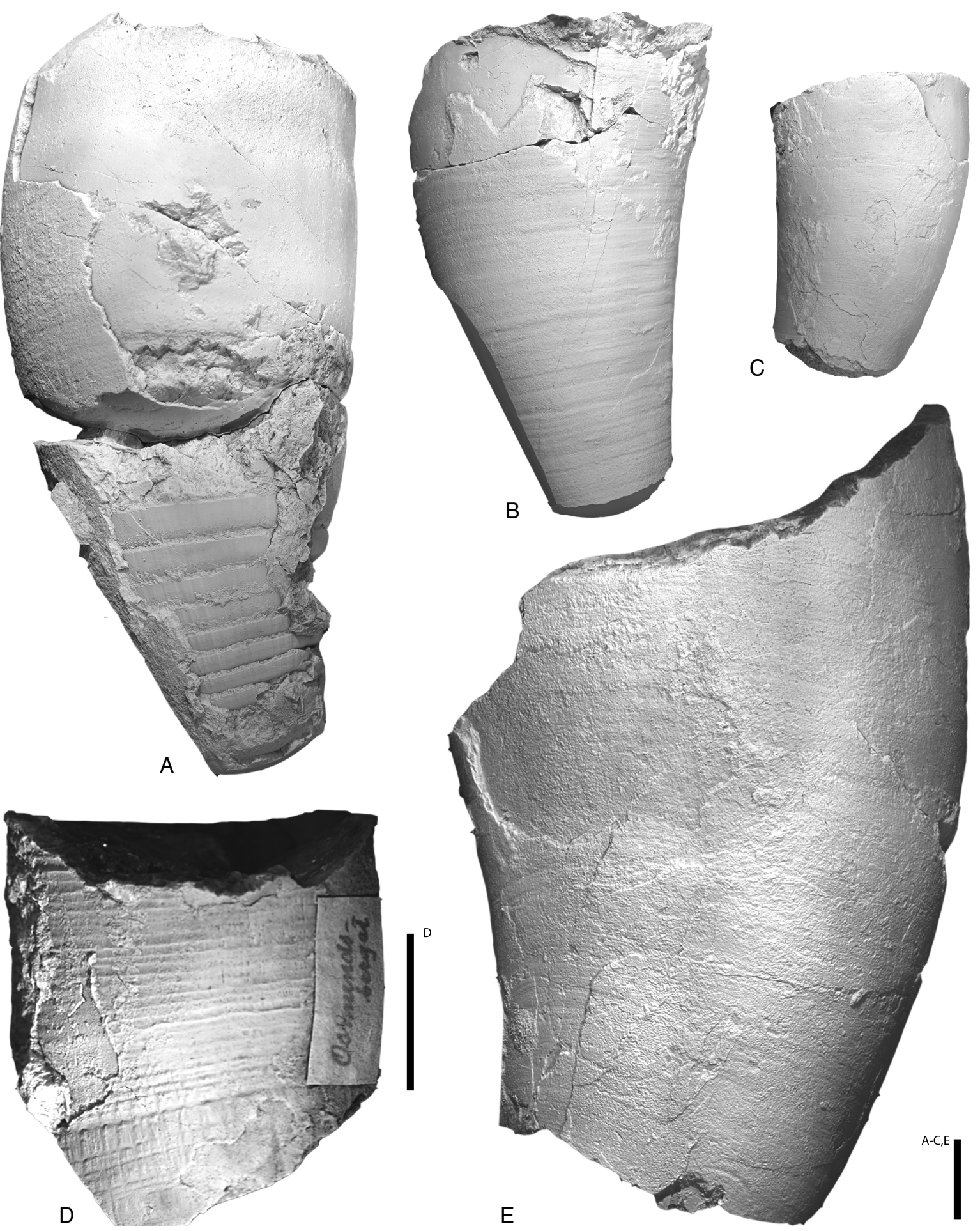

Fig. 7. Breviconic cephalopods of the Boda Limestone and details of an endocerid. A. Dalecarlioceras constrictum Frye, 1987, PMU 24777, holotype, Kallholn. B. Dalecarlioceras dalecarlicum (Frye, 1987) comb. nov., PMU 24774, holotype, Kallholn. C. Cyrtorizoceras thorslundi sp. nov., PMU 26658, Kallholn; note the morphological transition between D. constrictum and C. thorslundi sp. nov.; the adult size increases in Dalecarlioceras and the mature body chamber is gibbous. D. Cameroceras turrisoides sp. nov., PMU 26623, Osmundberget, lateral view of apical fragment with abrupt transition between embryonic and juvenile conch. E. Strandoceras sphinx (Schmidt, 1858), PMU 26629, Kallholn. Scale bars: A-C, $\mathrm{E}=10 \mathrm{~mm} ; \mathrm{D}=10 \mathrm{~mm}$. 
shell is markedly conical (apical angle ca. $25^{\circ}$ ) and has a compressed conch cross section (width/height ratios of ca. 0.88). The shell surface is ornamented with irregular longitudinal grooves and appears thickened and irregularly wrinkled around the circumference in a longitudinal direction. At its adoral end there is a marked change in growth, initiated by a constriction and an abrupt change in the angle of expansion. The conch portion $30 \mathrm{~mm}$ adorally of the termination of the apical part of the shell is nearly tubular and ornamented with the characteristic transverse ornamentation of a more mature specimen. This conch portion is additionally weakly longitudinally ornamented with irregular striae. The change in growth is accompanied by a marked increase in shell thickness. In specimen PMU 26623 the shell adapically of the growth change is less the $0.5 \mathrm{~mm}$ thick, at the position of the constriction it is only $0.4 \mathrm{~mm}$, and rapidly increases adorally to ca. $1 \mathrm{~mm}$. The diameter of the siphuncle at the position of the constriction is $9 \mathrm{~mm}$. There the siphuncle is nearly marginal, only one millimetre distant from the conch margin.

The apex is eccentrically positioned marginally on the prosiphuncular side of the conch. The extreme tip is not preserved, but the slight decrease of the apical angle at the apicalmost preserved part may represent the fragment of a subspherical initial shell (Fig. 6B).

\section{Remarks}

The apex of $C$. turrisoides sp. nov. is exceptional in form and size, but not entirely unknown. A very similar apex was described as Endoceras akpatoense Foerste \& Cox, 1936, from the latest Katian of the Arctic Canadian Island Akpatok. This specimen differs in having even larger dimensions and a less curved extreme apical part. Based on the genus diagnosis of Cameroceras of Teichert (1964, see above) this species must be recombined as Cameroceras akpatoense (Foerste \& Cox, 1936) comb. nov.

\section{Comparison}

This very large species of Cameroceras is most similar to Endoceras windriverense Miller, 1932 (based on the generic diagnosis of Cameroceras, see above, this species must be recombined as Cameroceras windriverense (Miller, 1932) comb. nov.) from the latest Katian Lander Formation from Canada, which has a relative siphuncle diameter of 0.35 and an SPR of 0.18 , but differs in having a lower angle of expansion and in having a nearly circular conch cross section. Additionally, the ornamentation of this species is not known.

Endoceras sp. B. Strand (1934) is interpreted as conspecific with C. turrisoides sp. nov., even though the conch surface of this specimen is not preserved, because it is identical in having a relatively thin siphuncle ( 0.4 of conch cross section), which is positioned at a distance from the conch margin (SPR 0.18 ) which is well within the range of the Boda specimen.

Although the conch surface is not known in the Cameroceras sp. reported by Evans (1994: fig. 6.1-2) from the Bardahessaigh Formation of Ireland, it is synonymized with C. turrisoides sp. nov. herein. This is justified by the size of the siphuncle ( 0.35 of conch cross section) and the relative distance of the siphuncle (SPR 0.14), which are both within the range of variation of the Boda specimen.

\section{Stratigraphic and geographic range}

Bardahessaigh Formation, mid-late Katian, Ireland (Evans 1994); Bønsnes Formation, Ringerike district, Norway (Strand 1934); Boda Limestone, late Katian, Siljan District, Sweden. 
Order Discosorida Flower in Flower \& Kummel, 1950

Family Cyrtogomphoceratidae Flower, 1940

Genus Kiaeroceras Strand, 1934

\section{Type species}

Kiaeroceras frognoyense Strand, 1934, Frognøya, Ringerike, Norway, Sørbakken Formation, late Katian, Late Ordovician; by original designation.

\section{Diagnosis}

Slender brevicones with ovate compressed cross section; a mature body chamber with pronounced constriction somewhat adapical of the peristome; aperture with deep and broad hyponomic sinus; sutures with lateral lobes and pronounced saddle on prosiphuncular side; siphuncle close to conch margin, with broadly expanded siphuncular segments, with prominent bulletes. (Adopted from Strand 1934.)

\section{Kiaeroceras heroyense Strand, 1934}

Fig. 8B-C

Kiaeroceras herøyense Strand, 1934: 99, pl. 9, fig. 5.

Kiaeroceras heroyense - Flower in Flower \& Teichert 1957: 60, text-fig. 17c.

\section{Diagnosis}

Kiaeroceras with strongly compressed conch cross section with width/height ratio of ca. 0.8. (Adopted from Strand 1934.)

\section{Type locality and horizon}

Herøya, near Porsgrunn, Norway; Herøya Formation ("Gastropod Limestone"), late Katian, Late Ordovician.

\section{Material examined}

PMU 26628 from Kallholn, Dalarna, Sweden; Boda Limestone, Upper Boda Member, Hirnantian, Late Ordovician.

\section{Description}

The specimen is a fragment of parts of the phragmocone and the body chamber of a mature individual (Fig. 8B, C). The conch is straight with a compressed cross section. At the base of the body chamber the maximum diameter is reached, with a height of $68 \mathrm{~mm}$ and a width of $55 \mathrm{~mm}$ (width/height ratio 0.81). At a position ca. $40 \mathrm{~mm}$ in apical direction, the conch height is $55 \mathrm{~mm}$ (angle of expansion, $18^{\circ}$ ). The preserved part of the body chamber is ca. $50 \mathrm{~mm}$ long. The conch surface is smooth with faint growth lines. The outer shell is relatively thick with ca. $1.5 \mathrm{~mm}$ at the base of the body chamber. The sutures form shallow lateral lobes, their distance is ca. $7 \mathrm{~mm}$ where the conch height is $60 \mathrm{~mm}(0.12$ of corresponding conch height). The septa are shallowly convex with convexity of ca. 0.1 of corresponding conch height. The siphuncle is marginal with a diameter of ca. 0.15 of the corresponding conch cross section. The siphuncular segments are strongly expanded within the chambers. 


\section{Remarks}

The specimen from the Boda Limestone is nearly identical in dimensions, septal convexity and chamber spacing to Kiaeroceras frognoyense Strand, 1934. However, Strand (1934) distinguished the two species of Kiaeroceras based on the shape of the conch cross section. As the width/height ratio of the conch of specimen PMU 26628 is 0.81 , it is more similar to K. heroyense than to K. frognoyense (with a width/ height ratio of 0.87), with a less compressed conch (Strand 1934: 97).

Kiaeroceras frognoyense and $K$. heroyense probably represent a continuous spectrum of morphological variation or sexual dimorphs. Given the paucity of known material, such speculation cannot be tested and the original species diagnoses of Strand (1934) are accepted herein.

The specimen, described above, is the most complete specimen known from this genus with regard to the phragmocone. It displays a curved lateral outline of both the pro- and antisiphuncular conch margin, an oval conch cross section and details of the shell surface.

\section{Stratigraphic and geographic range}

Herøya Formation, Norway (Strand 1934); Boda Limestone, Upper Boda Member, Hirnantian, Dalarna, Sweden; all late Katian-Hirnantian.
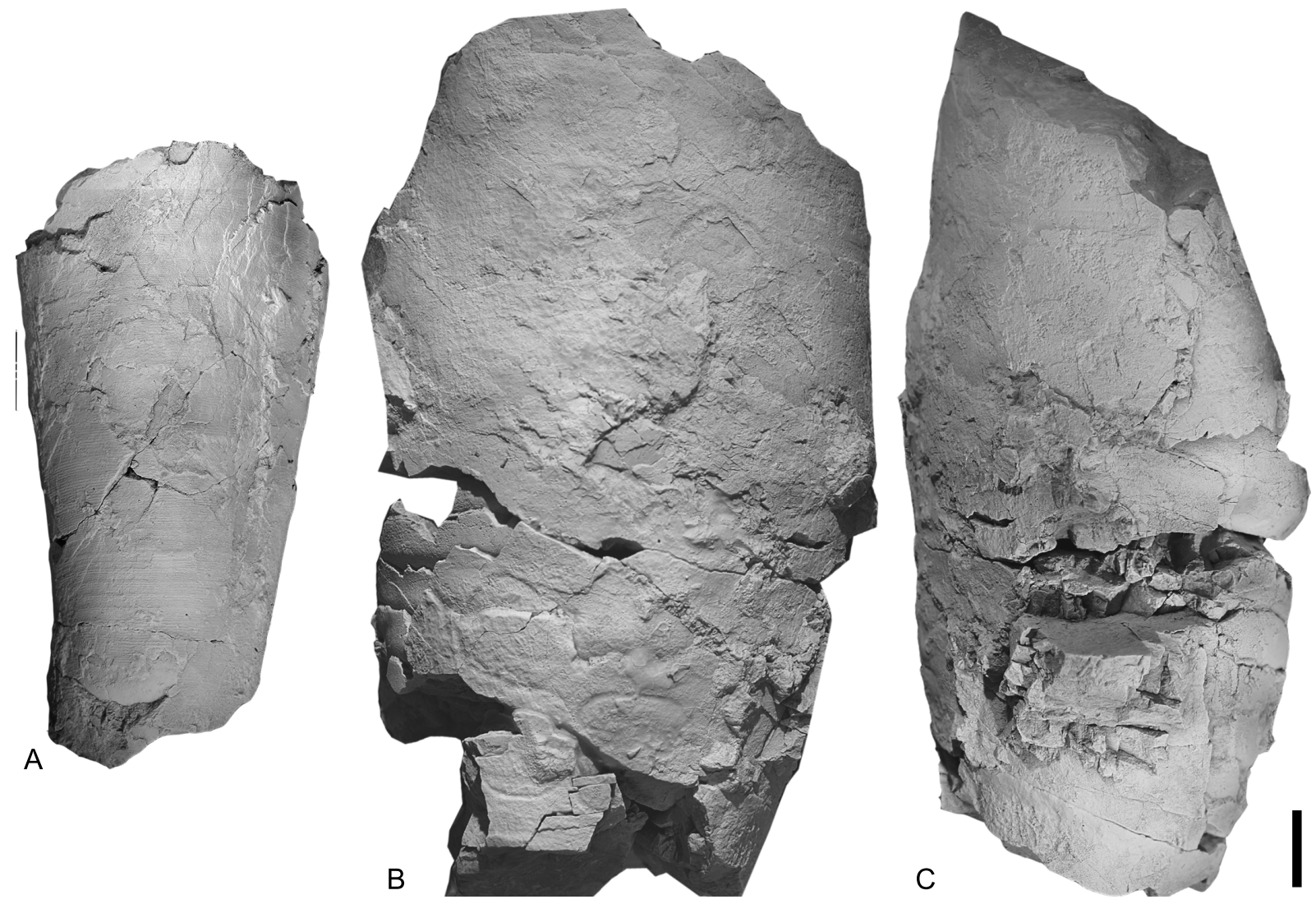

Fig. 8. Orthoconic brevicones of the Boda Limestone of Kallholn. A. Tyrioceras cf. kjaerulfi Strand, 1934, PMU 26897, view from antisiphuncular side. B-C. Kiaeroceras heroyense Strand, 1934, PMU 26628. B. Lateral view, with siphuncle on left side. C. View from antisiphuncular side. Scale bar $=10 \mathrm{~mm}$ for all figures. 
Genus Strandoceras Flower, 1946

\section{Type species}

Protophragmoceras tyriense Strand, 1934, Stavnestangen, Ringerike, Norway, Gastropod Limestone, late Katian, Late Ordovician; by original designation.

\section{Diagnosis}

Strongly compressed cyrtocones with narrowly rounded venter; in conch cross section shallow longitudinal furrow at left and right flank in direct vicinity of siphuncle; siphuncle close to concave margin of conch; sutures with shallow lateral lobe and acute ventral saddle; septal necks are short cyrtochoanitic; connecting ring thick, strongly expanded within chambers; aperture is open with shallow peristomal saddle at flank. (Adopted from Kröger 2007.)

\section{Strandoceras sphinx (Schmidt, 1858)}

Fig. 7E

Phragmoceras sphynx Schmidt, 1858: 200.

Protophragmoceras sphinx - Teichert 1930: 270, 299-301, pl. 7, fig. 20, pl. 8, fig. 24, text-figs 3, 4. Dzik 1984: 48, 52, 65, text-fig.14.5, pl. 7, fig. 7.

Protophragmoceras sphynx - Strand 1934: 93.

Strandoceras sphynx - Flower in Flower \& Teichert 1957: 57, 114, text-figs 15e, g-h.

Strandoceras sphinx - Balashov 1975: 69, pl. 2, fig. 1.

\section{Diagnosis}

Strandoceras with moderate curvature, angle of expansion 16-19 ; compressed conch cross section with width/height ratio of $0.8-0.9$; body chamber long, reaching 0.4 of total conch length; ornamented with distinctive transverse rounded striae, which form shallow sinuses on the anti- and prosiphuncular side of the conch. (Adopted from Strand 1934 and Dzik 1984.)

\section{Type locality and horizon}

"Setlep", Island Vormsi, Estonia, Vormsi/Pirgu Regional Stage ("Lyckholm stage", Teichert 1930), late Katian, Ordovician.

\section{Material examined}

Three specimens (PMU 26629-26631) from Kallholn, Dalarna, Boda Limestone; one specimen (PMU 26632) from Amtjärn, Dalarna, Johnstorp Formation. All late Katian, Late Ordovician.

\section{Description}

The largest specimen, PMU 26629, is a piece of phragmocone, measuring 74-48 $\mathrm{mm}$ in height, and with a maximum width of $63 \mathrm{~mm}$ (width/height ratio 0.85 ) and expanding at an angle of $19^{\circ}$ (Fig. 7E). The conch cross section is broadly rounded on the antisiphuncular side and forms a characteristic narrow subangular margin on the prosiphuncular side. Adorally the siphuncle measures ca. $6 \mathrm{~mm}$ in diameter ( 0.08 of conch height) and is almost marginal in position on the concave side of the conch. The septa are narrowly spaced at a distance of ca. $8 \mathrm{~mm}$ (ca. 0.11 of corresponding conch height) in the adoral part of the fragment. The sutures are directly transverse. The conch surface is ornamented with fine, relatively widely spaced rounded transverse striae, distance between striae is ca. $3 \mathrm{~mm}$ at the adoral part of the fragment. The striae form a broadly curved lateral salient and shallow sinuses on the pro-, and antisiphuncular sides. 
A second specimen, PMU 26631, consists of a portion of phragmocone with a conch height of $16 \mathrm{~mm}$ apically. Shallow rounded striae ca. $0.7 \mathrm{~mm}$ in width are displayed on the apical part of the phragmocone. These are almost directly transverse, but form shallow sinuses on the the pro-, and antisiphuncular sides of the conch.

\section{Remarks}

The specimens from the Boda Limestone are very similar to the specimen described and figured from the Vormsi/Pirgu Regional Stage of Estonia ("Lyckholm stage" of Teichert 1930: pl. 8, fig. 24) which has a width/height ratio of the conch of 0.76 , an apical angle of ca. $16^{\circ}$ and a similar ornamentation and curvature.

\section{Comparison}

S. strandi Sweet, 1958 differs from S. sphinx in its more compressed conch cross section (width/height $=0.68$ ). S. tyriense differs from S. sphinx in its smaller adult size (ca. $60 \mathrm{~mm}$ conch height) and stronger curvature of the conch.

\section{Stratigraphic and geographic range}

Upper Herøya Formation ("Gastropod Limestone"), Skien-Langesund district, Norway (Strand 1934); erratic limestone boulders from Vormsi/Pirgu Regional Stage, Zgierz, Poland (Dzik 1984); Vormsi/Pirgu Regional Stage ("Lyckholm stage"), Estonia (Teichert 1930); Molodov Horizon, Podolia (Balashov 1975); Johnstorp Formation (“Grey Tretaspis Shale”), Boda Limestone, Dalarna, Sweden; all late Katian.

Order Oncocerida Flower in Flower \& Kummel, 1950

Family Oncoceratidae Flower in Flower \& Kummel, 1950

Genus Beloitoceras Foerste, 1924

\section{Type species}

Oncoceras pandion Hall, 1861, Black River Formation, Beloit, Wisconsin, USA; by original designation.

\section{Diagnosis}

Strongly curved, relatively slender brevicones with ovate, compressed cross section. Conch smooth or with fine transverse ornament. Maximum conch diameter situated within adapical half to third of body chamber. Antisiphuncular outline of conch concave over entire length in longitudinal section, prosiphuncular outline broadly convex. Five to eight chambers per distance similar to corresponding conch cross section. Body chamber short with well developed hyponomic sinus at convex side. Siphuncle slender, situated close to convex margin of conch curvature, with subtubular segments. Septal necks short suborthochoanitic to cyrtochoanitic. Connecting rings thin. (Compiled from Sweet 1964b and Frey 1995.)

Beloitoceras sinuososeptatum (Roemer, 1861)

Figs 9A-B, 11

Orthoceras sinuoso-septatum Roemer, 1861: pl. 6, fig. 3a-c.

Beloitoceras heterocurvatum Strand, 1934: 76, pl. 10, figs 8-9.

Richardsonoceras sinuososeptatum - Dzik 1984: 188, text-fig. 16a-b, pl. 8, fig. 1a-d.

Beloitoceras heterocurvatum - Frye 1987: 84, figs 3a-d. — Kröger et al. 2011: 38, fig. 5a-b. 


\section{Emended diagnosis}

Beloitoceras with compressed cross section with keeled conch margins at concave and convex side of conch curvature throughout entire length; in longitudinal section antisiphuncular conch margin concave; angle of expansion of phragmocone ca. $16-17^{\circ}$; depth of body chamber somewhat less than maximum conch height; conch surface ornamented with irregularly spaced rounded striae, which form a shallow sinus on prosiphuncular side and deep v-shaped sinus on antisiphuncular side; about six chambers
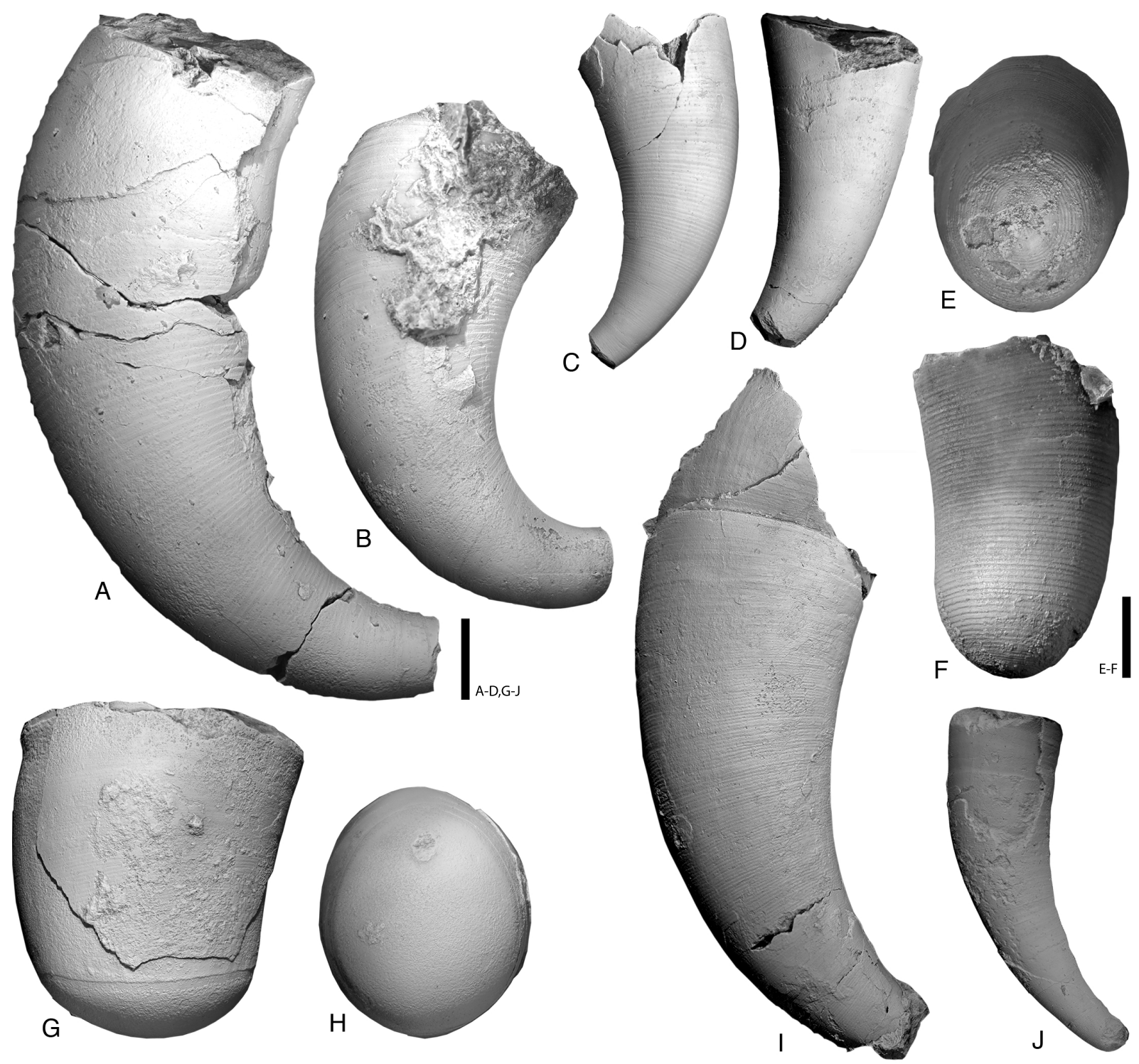

Fig. 9. Oncerida of the Boda Limestone. Note the high variability in conch curvature and angle of expansion in Beloitoceras. A-B. Beloitoceras sinuososeptatum (Roemer, 1861). A. PMU 24769. B. PMU 26638, Kallholn. C-D. Beloitoceras siljanense Frye, 1987. C. PMU 26644. D. PMU 26645, Kallholn. E-F. Apex of Beloitoceras sp., PMU 26646, Kallholn. E. Adapical view. F. Lateral view. G-H. Cyrtorizoceras thorslundi sp. nov., PMU 26657, Osmundsberget, mature body chamber. G. Lateral view. H. Adapical view. I. Beloitoceras siljanense Frye, 1987, PMU 26643, Kallholn, with major conch repair at adoral part. J. Cyrtorizoceras thorslundi sp. nov., PMU 26647, holotype, Kallholn, complete juvenile specimen. Scale bars: A-D, G-J $=10 \mathrm{~mm}$; E-F $=2 \mathrm{~mm}$. 
similar to the height of the conch cross section; sutures with deep lateral lobes; siphuncle situated near ventral margin, segments ca. twice as high as wide, with slightly convex vertical outline.

\section{Type locality and horizon}

Zawidowice near Oleśnica, Poland, erratic boulder of probably latest Katian age, Ordovician.

\section{Material examined}

Thirteen specimens in total: PMU 26633-26642, 24769, 24772, Kallholn, Dalarna; one specimen (PMU 24770), Skålberget, Dalarna, Boda Limestone, late Katian.

\section{Description}

The general features of the conch, the ornamentation and the details of the siphuncle were described by Strand (1934), Dzik (1984) and Frye (1987). These descriptions were based on relatively few specimens. Here, 15 additional specimens are available for measurements and direct comparison. These specimens reveal a high variability in conch curvature and angle of expansion. The conch curvature varies from strongly curved to relatively widely curved (Fig. 9A-B). The angle of expansion varies from $15^{\circ}\left(1^{\text {st }}\right.$ quantile $)$ to, $18^{\circ}$ ( $3^{\text {rd }}$ quantile $)$ with a mean of $17^{\circ}$ (15 measurements) in the specimens from the Boda Limestone. The conch cross section is always compressed with a typical keel at the anti-, and prosiphuncular side, but the rate of compression varies among the Boda Limestone specimens from 0.85 ( $1^{\text {st }}$ quantile) to 0.92 ( $3^{\text {rd }}$ quantile) with a mean of 0.87 (10 measurements). Within this range of variance no distinct groups of specimens can be distinguished (Fig. 11).

\section{Remarks}

In earlier descriptions the variability of the conch shape of this species was not recognized. Additionally, the adult size of different specimen assigned to this species varies from 28 to $38 \mathrm{~mm}$ maximum body chamber height. Because only three specimens from the Boda Limestone possess an adult body chamber (specimen figured in Frye 1987: fig. 3a, b; PMU 24769, 26634), it is impossible to evaluate whether this difference reflects interspecific variability, sexual dimorphism or the presence of more than one species.

The type specimen from Vormsi/Pirgu Regional Stage limestones of the erratic boulders of northern Poland, figured by Dzik (1984, pl. 8, fig. 1a-d), differs from the Boda Limestone specimens in its exceptionally low angle of expansion of only $10^{\circ}$. Moreover, the paratype figured by Dzik (1984), with a width/height ratio of 0.72, and the specimen from the Oslo area figured by Strand (1934: pl. 10, fig. 8) are considerably more compressed than the specimens from the Boda Limestone. Also, these two specimens represent the lower range of the angle of expansion for all the specimens measured (Fig. 11). However, based on the available information it is impossible to distinguish different species of Beloitoceras among the specimens figured and described by Dzik (1984: pl. 8, fig. 1a-d), Strand (1934), Frye (1987: fig. 3a, b) and the material described herein. Based on the available material, B. sinuososeptatum is considered a species of Beloitoceras with a highly variable conch curvature, high variance in the angle of expansion (Fig. 11), and potentially encompasses macro-, and microconch varieties.

An apical fragment, PMU 26646, is interpreted as Beloitoceras sp. (Fig. 9E-F), because of its similarity in general conch shape and ornamentation with the larger fragments. The apex is cup-shaped and reaches a conch height of $4.3 \mathrm{~mm}$ and a width of $4 \mathrm{~mm}$ at a distance of $2 \mathrm{~mm}$ from the tip. The shell of this specimen is ornamented with fine rounded transverse annuli (ca. 8-10 per millimetre), which form a shallow hyponomic sinus on the concave side of the curved conch. 


\section{Comparison}

Two groups of Beloitoceras are distinguishable within the Boda Limestone. According to Frye (1987), B. siljanense Frye, 1987 can be distinguished from B. sinuososeptatum in having an antisiphuncular conch margin that straightens relatively early during growth and remains straight in the mature body chamber. By contrast, in $B$. sinuososeptatum the antisiphuncular conch margin is entirely curved along the entire length of the concave side of the conch. It was emphasized above that the conch curvature and angle of expansion vary strongly between specimens of Beloitoceras from the Boda Limestone. Within this continuous spectrum of variation, the types of both species represent two extremes with a maximum conch expansion in B. siljanense Frye, $1987\left(23^{\circ}\right)$ and a minimum in B. sinuososeptatum $\left(10^{\circ}\right)$. Based on the angle of expansion alone, it is not possible to distinguish between the two species (Fig. 11). $B$. siljanense may be distinguished from $B$. sinuososeptatum in having a finer transverse ornamentation and a less curved antisiphuncular conch margin (compare Fig. 9A-B, C-D).

Beloitoceras landerense Foerste, 1935 from the mid Katian Lander Sandstone of Wyoming, USA is very similar to B. sinuososeptatum in general conch shape and dimensions (Fig. 11). As the details of the ornamentation of this species are not known, direct comparison and synonymisation with $B$. sinuososeptatum is not possible at present.

Beloitoceras whitneyi (Hall, 1861) from the Elgin Formation, late Katian, Iowa, USA is similar to $B$. sinuososeptatum in general conch shape, its transversely ornamented shell, and in possessing a relatively large adult conch height of ca. $35 \mathrm{~mm}$. It may be conspecific with the Boda specimens, but with ca. 9-10 chambers in a length similar to the corresponding conch height, the chamber distance (cameral depth) is significantly lower in Beloitoceras whitneyi than that of $B$. sinuososeptatum (six chambers per length similar to corresponding conch height) and nothing is known about the variability of this character in either species. A synonymisation of this species is very likely, but may only be possible to demonstrate after comparison of the variability of the chamber height in both assemblages.

\section{Stratigraphic and geographic range}

Bønsnes Formation, Ringerike district, Skogerholm Formation, Oslo-Asker district, Norway (Strand 1934); erratic limestone boulders from Vormsi/Pirgu Regional Stage ("Lyckholm stage"), Zawidowice, Poland (Dzik 1984); Vormsi/Pirgu Regional Stage ("Lyckholm stage"), Estonia (Teichert 1930); Boda Limestone, Dalarna, Sweden; all late Katian.

Genus Cyrtorizoceras Hyatt in Zittel, 1900

\section{Type species}

Cyrtoceras minneapolis Clarke, 1897, Minneapolis, Minnesota, USA, Platteville Formation, early to mid Katian, Late Ordovician; by original designation.

\section{Diagnosis}

Compressed cyrtocones with conchs expanding constantly on anti- and prosiphuncular side; body chamber slightly contracted; aperture with deep hyponomic sinus; surface ornamented with obscure or prominent transverse costae; siphuncle close to conch margin on convex side of conch curvature, slender; siphuncular segments slightly expanded, probably empty. (Adopted from Sweet 1964a.)

\section{Comparison}

Cyrtorizoceras is similar to Richardsonoceras Foerste, 1932 in having a gradually enlarging cyrtoconic conch with a curved mature body chamber. Cyrtorizoceras differs from Richardsonoceras in having 
a generally less curved conch, higher angles of expansion and a mature body chamber with a more pronounced, angular sinus on the prosiphuncular side of the mature body chamber.

\section{Remarks}

This is a species rich genus with more than 35 species described, mostly known from the Late Ordovician of North America. The genus is in need of revision, as it probably encompasses several distinct and perhaps distantly related groups of cyrtoconic oncoceratids, all possessing a simple, non gibbous body chamber.

\section{Cyrtorizoceras thorslundi sp. nov. urn:1sid:zoobank.org:act:3B69DD96-E0F9-4516-9383-6DC8FF7D0BFD}

Figs 7C, 9G-H, J, 10A

\section{Diagnosis}

Cyrtorizoceras with adult body chamber height of ca. $35 \mathrm{~mm}$ and angle of expansion of $12-13^{\circ}$; conch cross section compressed, ovate, with slightly angular anti- and prosiphuncular margins and with width/

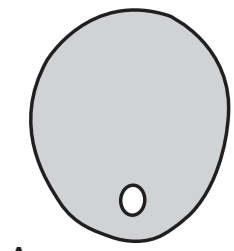

A

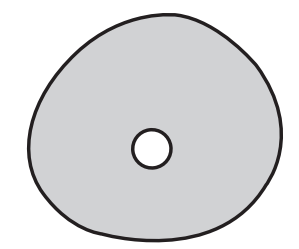

B

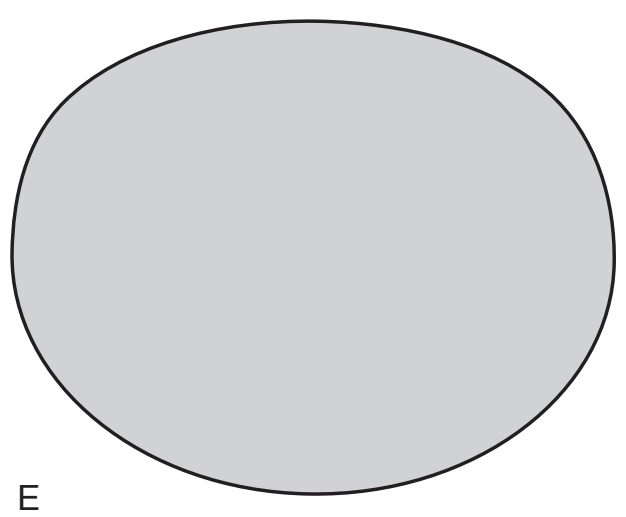

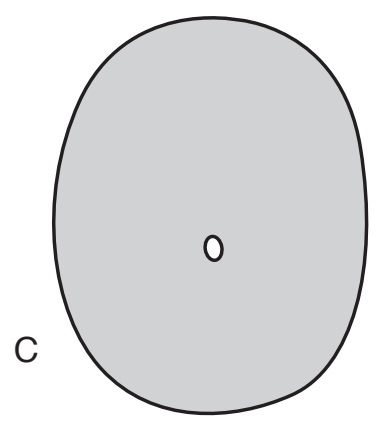

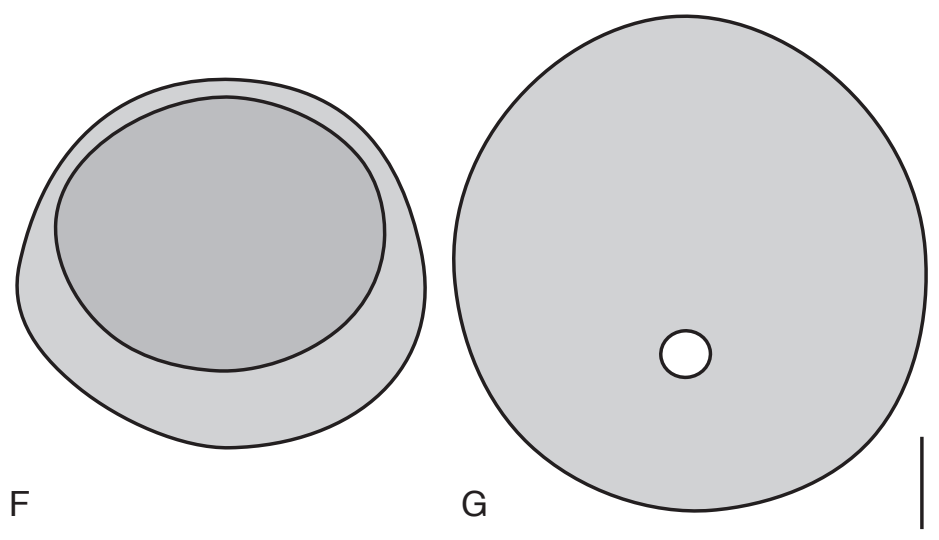

Fig. 10. Camera lucida drawings of cross sections of selected Boda Limestone cephalopods. A. Cyrtorizoceras thorslundi sp. nov., PMU 26657, Osmundsberget, mature body chamber. B. Tyrioceras cf. kjaerulfi Strand, 1934, PMU 26897, Kallholn. C. Nathorstoceras adnatum sp. nov., PMU 26733, holotype, Kallholn. D. Nathorstoceras kallholnense sp. nov., PMU 26729, holotype. E. Redpathoceras depressum sp. nov., PMU 26927, holotype, Kallholn, cross section of base of mature truncated conch. F. Schuchertoceras fryi sp. nov., PMU 24744, holotype, Kalllholn, cross section of mature aperture (dark grey) and body chamber (medium grey). G. Redpathoceras bullatum sp. nov., PMU 26923, holotype, Kallholn, cross section of base of mature truncated conch. Prosiphuncular side directed downward in all figures. Siphuncles shown as white circles. Scale bar $=10 \mathrm{~mm}$ for all figures. 
height ratio of ca. $0.8-0.9$; ornamented with fine, rounded, directly transverse striae; adult body chamber length $30 \mathrm{~mm}$ with angle of expansion similar to premature conch, shallow constriction and adoral widening at adult peristome; shallow angular sinus at prosiphuncular side; mature portions of conch slightly less coiled than adapical parts; apex large, cap-shaped.

\section{Etymology}

In honour of Per Thorslund (1900-1991), Swedish geologist and paleontologist and professor at Uppsala University (1950-1966), for his important contributions on the geology of the Siljian region (e.g., Thorslund 1935).

\section{Type material}

\section{Holotype}

PMU 26647.

\section{Paratypes}

Twelve additional specimens (paratypes): PMU 26648-26659 from Kallholn, Dalarna, Sweden, Boda Limestone, Boda Core Member, late Katian.

\section{Type locality and horizon}

Kallholn, Dalarna, Sweden, Boda Limestone, Boda Core Member, late Katian, Ordovician.

\section{Description}

The holotype is a complete juvenile specimen with a conch length of ca. $40 \mathrm{~mm}$, maximum conch width at peristome $11 \mathrm{~mm}$, conch height $13 \mathrm{~mm}$, a ca. $15 \mathrm{~mm}$ long body chamber and a nearly complete apical portion (Fig. 9J). Apically the conch grows from the absolute tip toward a conch height of $4 \mathrm{~mm}$ within the first $2 \mathrm{~mm}$. The conch surface of the holotype is ornamented with rounded striae, which run straight and form a shallow sinus at the prosiphuncular side; ca. five occur per one millimeter at the adoral parts of the conch.

In specimen PMU 26648, which is a fragment of the phragmocone, the septa and the siphuncle are exposed. The septa are simply curved, and the sutures form shallow lateral lobes $1.9 \mathrm{~mm}$ distant where
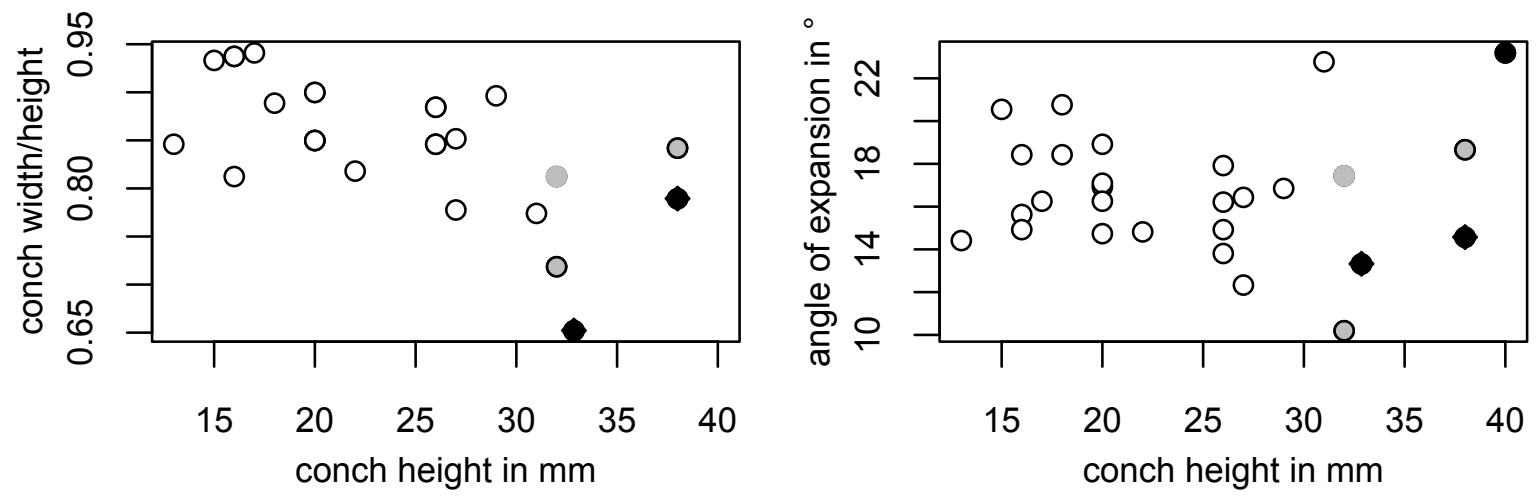

Fig. 11. Morphological variation of Beloitoceras sinuososeptatum (Roemer, 1861). Circles: specimens of the Boda Limestone. Black dot: type specimen of Beloitoceras siljanense Frye, 1987. Black diamonds: types of Beloitoceras heterocurvatum Strand, 1934. Grey dot: type specimen of Beloitoceras landerense Foerste, 1935. A distinction between B. siljanense and B. sinuososeptatum is impossible based on the available material. 
the corresponding conch height is $10.5 \mathrm{~mm}$ ( 0.18 of corresponding conch height). The siphuncle is nearly, but not exactly marginal, its width is $0.6 \mathrm{~mm}$ at a corresponding conch height of $6.6 \mathrm{~mm}$ (ca. 0.9 of conch height). The siphuncular segments are slightly expanded and the connecting ring is comparatively thin.

The angle of expansion varies only very little among the eight specimens, with $11.5^{\circ}$ (PMU 26649) to $13.3^{\circ}$ (holotype).

The adult conch height of $34 \mathrm{~mm}$ and width $28 \mathrm{~mm}$ is indicated by three body chambers of similar size with distinct peristomal shell thickenings (PMU 26656, 26657, 26659; Figs 9G-H, 10A). These fragments of the body chambers are ornamented with fine transverse striae that form a distinct shallow sinus at the prosiphuncular side. The striae are ca. $1 \mathrm{~mm}$ wide.

\section{Remarks}

The material described above consists of eight juvenile specimens and three adult body chambers. No fragments of intermediate growth stages are known. The fragments are assigned to Cyrtorizoceras thorslundi sp. nov. because they have a similar conch curvature and nearly identical angles of expansion, cross section shapes and ornamentation.

\section{Comparison}

This species differs from the type of the genus in having a more slender body chamber, a less pronounced ornamentation and a shallower conch curvature. Cyrtorizoceras thorslundi sp. nov. is unique amongst the other species assigned to the genus in its combination of a fine transverse ornamentation with a relatively weak conch curvature.

The poorly preserved fragment, described by Teichert (1930) as Beloitoceras (?) estonicum from the Pirgu Regional Stage of Hosholm, Estonia, is very similar to C. thorslundi sp. nov. in general conch shape and should very probably be synonymised with the latter. However, better preserved material is needed for a definitive comparison.

The small C. tenue Strand, 1934 from the Gastropod Limestone of the Oslo region is very similar to C. thorslundi sp. nov. with respect to the general conch shape, size and ornamentation. However, in C. tenue the angle of expansion is considerably higher (ca. $17^{\circ}$ ), and the conch is more strongly curved.

The juvenile specimens of $C$. thorslundi sp. nov. can be distinguished from specimens of Beloitoceras in the Boda limestone by its broader conch curvature and low angle of expansion.

\section{Stratigraphic and geographic range}

Boda Limestone, late Katian, Dalarna, Sweden.

\section{Genus Dalecarlioceras Frye, 1987}

\section{Type species}

Dalecarlioceras bodense Frye, 1987, Kallholn, Dalarna, Sweden, Boda Limestone, late Katian, Late Ordovician; by original designation.

\section{Diagnosis}

Cyrtocones with moderate to large angle of expansion, compressed conch cross sections; conch curved with siphuncle close to conch margin on convex side of conch curvature; body chamber gibbous with 
maximum gibbosity at mid-length, becoming compressed orad with profile on antispihuncular side faintly concave, moderately convex on prosiphuncular side; aperture may be constricted with prominent hyponomic sinus; siphuncle small in diameter with tubular, somewhat expanded segments that are empty. (Adopted from Frye 1987.)

Dalecarlioceras dalecarlicum (Frye, 1987) comb. nov.

Fig. 7B

Cyrtorizoceras dalecarlicum Frye, 1987: 88, 89, fig. 6d-f.

\section{Emended diagnosis}

Dalecarlioceras with slightly curved adult body chamber, with maximum adult height/width of ca. $40 / 38 \mathrm{~mm}$, and adult peristome height/width $37 / 33$.

\section{Holotype}

PMU 24774.

\section{Type locality and horizon}

Kallholn, Siljan District, Sweden, Boda Limestone, Boda Core Member, late Katian, Ordovician.

\section{Other material examined}

One specimen (PMU 24775) from Kallholn, Dalarna; one specimen from Rättvik, Dalarna, NRM Mo 150043, Boda Limestone, Boda Core Member, late Katian.

\section{Description}

See Frye (1987: 88-89) for a detailed description.

\section{Remarks}

Dalecarlioceras is endemic to the Boda Limestone. Originally, two species were assigned to this genus: the large $D$. bodense, characterized by a high angle of expansion, and the somewhat smaller, more slender D. constrictum Frye, 1987 (Fig. 7A). Herein, the medium sized Cyrtorizoceras dalecarlicum Frye, 1987 is considered an additional species of Dalecarlioceras. Dalecarlioceras dalecarlicum (Frye, 1987) comb. nov. has an only slightly curved adult body chamber, combined with a slightly irregularly spaced ornamentation with transverse growth lines similar to those of $D$. bodense. The mature body chamber of $D$. dalecarlicum comb. nov. differs from that of Cyrtorizoceras in having a nearly straight, or slightly concave outline in lateral view (Fig. 7B-C); it is clearly compressed at the aperture in frontal view. Consequently, the body chamber of $D$. dalecarlicum comb. nov. is widest approximately at mid-length, like in $D$. bodense. $D$. dalecarlicum comb. nov. is considered to represent a transitional form between D. constrictum and Cyrtorizoceras thorslundi sp. nov. Together these forms represent a transition from the relatively small and slender $C$. thorslundi sp. nov., with a weakly gibbous body chamber, toward the massive, and strongly gibbous $D$. bodense. This suggests an ancestry or close relationship of Dalecarlioceras to Cyrtorizoceras.

\section{Stratigraphic and geographic range}

Boda Limestone, Dalarna, Sweden; late Katian. 
Order Orthocerida Kuhn, 1940

Suborder Orthoceratina Kuhn, 1940

Family Orthoceratidae McCoy, 1844

Genus Striatocycloceras Kröger \& Isakar, 2006

\section{Type species}

Orthoceras undulostriatum Hall, 1847 from the Trenton Formation, late Katian of Middleville, New York, USA.

\section{Diagnosis}

Slender, circular or slightly compressed orthocones with asymmetrically curved septa and straight transverse or slightly oblique sutures. Sutures parallel, or nearly so, to the annulations; annulations slightly irregularly spaced, with fine transverse ornament; siphuncle eccentric, narrow, tubular or slightly expanded within the chambers; septal necks orthochoanitic. Cameral and endosiphuncular deposits not known.

\section{Remarks}

The captions of the figures of the species of Striatocycloceras in Kröger \& Isakar (2006) are erroneous and misleading. The errors must be corrected as follows: Striatocycloceras obliquum (Teichert, 1930) is figured in Kröger \& Isakar (2006: figs 7k, o, 8d, 11), as correctly stated in the text, and Striatocycloceras undulostriatum (Hall, 1847) is also correctly figured (Kröger \& Isakar 2006: figs 71 8e, 10a); other species shown are Striatocycloceras romingeri (Foerste, 1932) (Kröger \& Isakar 2006: figs 7p, 8r-t) and Striatocycloceras foerstei (Teichert, 1930) Kröger \& Isakar (2006: figs 7q, 10h).

\section{Comparison}

Striatocycloceras is similar in ornamentation and conch shape to the dawsonoceratid Anaspyroceras Shimizu \& Obata, 1935, which differs in having short, nearly achoanitic septal necks.

Striatocycloceras isbergi sp. nov. urn:1sid:zoobank.org:act:23541702-00D8-4063-AE65-6799DE63E2AD

Figs 12B-C, 13B-C, 14A

Striatocycloceras foerstei - Kröger \& Isakar 2006: 151, figs 7q, $10 \mathrm{~h}$.

\section{Diagnosis}

Slender orthocones with apical angle less than $10^{\circ}$ and conch cross section less than $15 \mathrm{~mm}$ at maturity; ornamented with eight to ten pronounced, sharply crested annuli at distance equal to corresponding conch diameter; annuli laterally oblique ca. $70^{\circ}$ to growth axis; ca. three annuli in distance between septa; siphuncle slightly subcentral; nearly tubular segments; septal necks orthochoanitic.

\section{Etymology}

In honor of Orvar Isberg (1884-1950), a Swedish paleontologist who published an extensive monograph on the Boda Limestone bivalves (Isberg 1934).

\section{Type material}

\section{Holotype}

PMU 26660 


\section{Paratypes}

Thirty-seven paratypes: one specimen (PMU 26661) from Osmundsberget; 36 specimens (PMU 26662 26698), Kallholn, Siljan District, Sweden; all Boda Limestone, Boda Core Member, late Katian.

\section{Type locality and horizon}

Kallholn, Siljan District, Sweden, Boda Limestone, Boda Core Member, late Katian, Ordovician.

\section{Description}

Holotype is a $45 \mathrm{~mm}$ long, 10-13 $\mathrm{mm}$ wide portion of phragmocone (angle of expansion $4^{\circ}$ ) with a circular conch cross section (Fig. 12B). The shell surface is ornamented with sharply crested annuli, of which ca. eight occur at a length equal to the conch diameter. The annuli form sharp, angular crests with
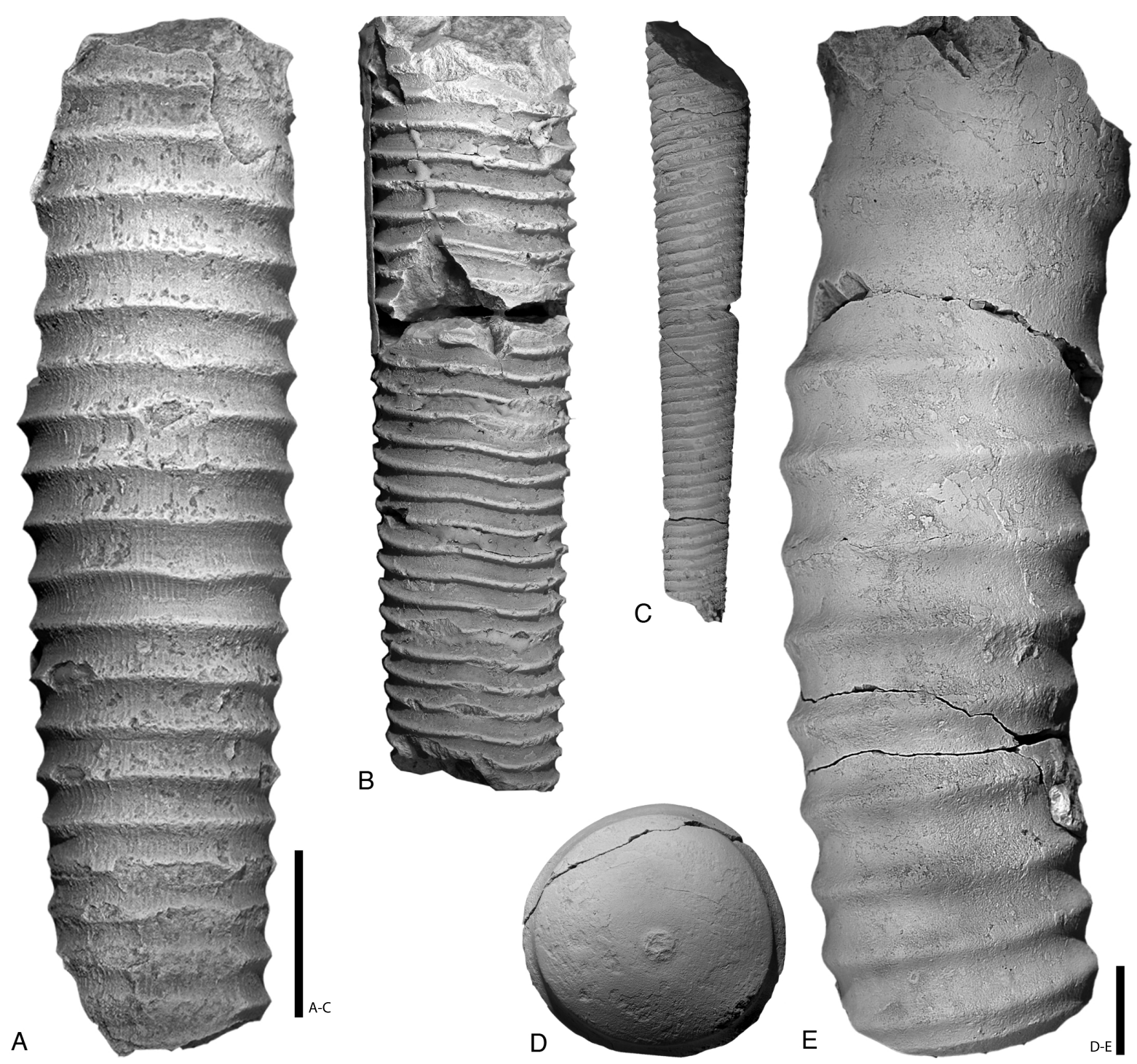

Fig. 12. Annelate Orthocerida of the Boda Limestone. A. Palaeodawsonocerina senckenbergi (Teichert, 1930), PMU 26718, Kallholn. B-C. Striatocycloceras isbergi sp. nov., Osmundsberget. B. PMU 26660 , holotype, Osmundberget. C. PMU 26664. D-E. Palaeodawsonocerina? nicolletoides sp. nov., PMU 26728, Kallholn. D. Adapical view. E. Lateral view. Scale A-C $=10 \mathrm{~mm}$; D-E $=10 \mathrm{~mm}$. 

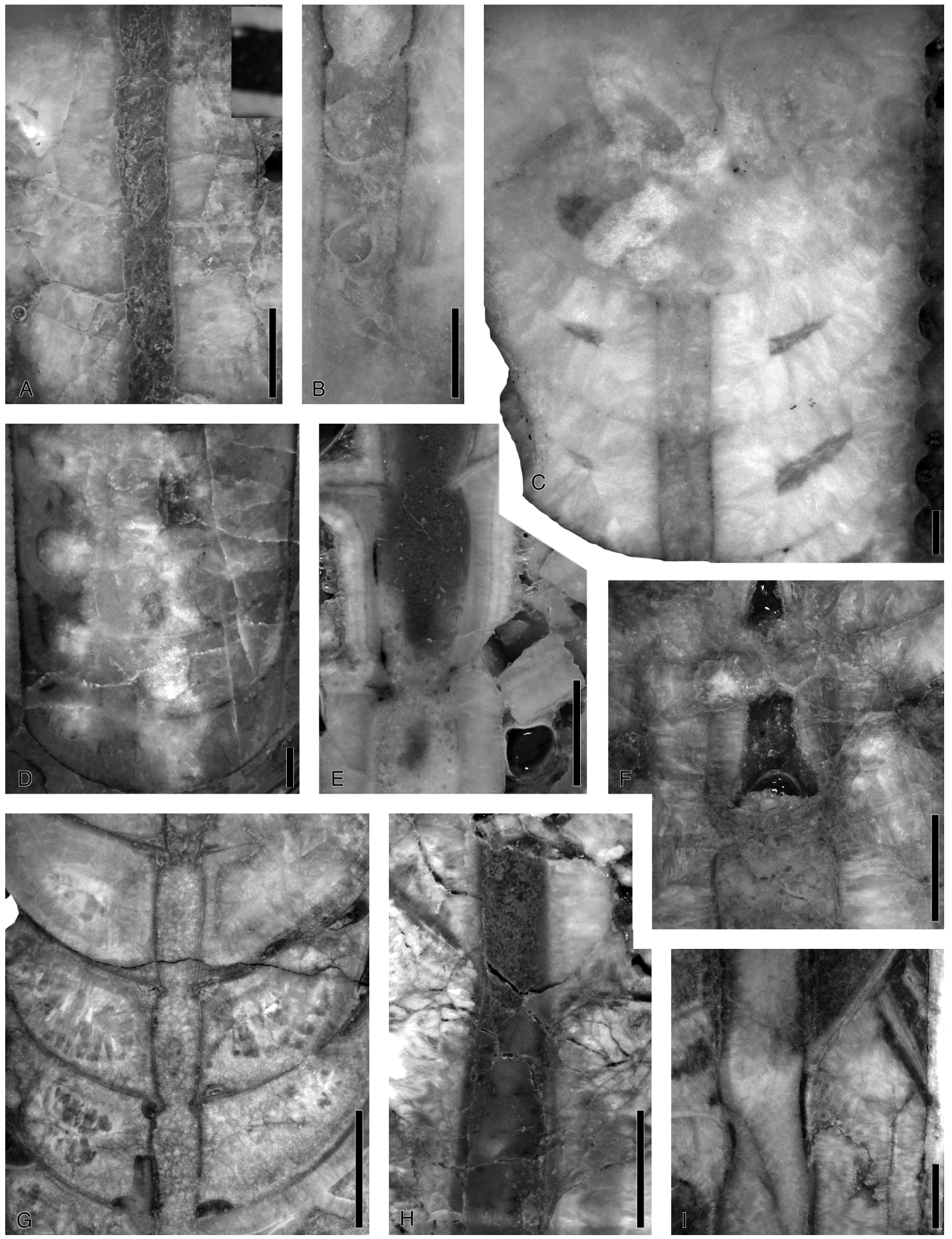

Fig. 13. Polished median sections of Orthocerida of the Boda Limestone. A. Dawsonoceras fenestratum (Eichwald, 1860), PMU 26706, Kallholn. B-C. Striatocycloceras isbergi sp. nov. B. PMU 26681, Kallholn. C. PMU 26661, Osmundsberget. D. Isorthoceras angelini sp. nov., PMU 26784, Kallholn. E. Nathorstoceras kallholnense sp. nov., PMU 26729, holotype, Kallholn. F. Nathorstoceras adnatum sp. nov., PMU 26733, holotype, Kallholn. G. Pleurorthoceras osmundsbergense sp. nov., NRM-PZ Mo, 190102c, Osmundsberget. H. Ordogeisonoceras foerstei (Strand, 1934)comb.nov., PMU 26763, Kallholn. I. Geisonoceras wegelini (Angelin in Angelin \& Lindström, 1880) comb. nov., PMU 26740, Kallholn. Scale bars: A-D, I = $1 \mathrm{~mm}$; E-H $=5 \mathrm{~mm}$. 
wide, rounded grooves. The shell surface is otherwise nearly smooth, with only very faint transverse growth lines visible. The annuli are oblique, at ca. $70^{\circ}$ to the growth axis. In specimen PMU 26661 the sutures are directly transverse and crossed obliquely by the annulations. The septa are markedly convex, being $3 \mathrm{~mm}$ deep at a conch diameter of $7 \mathrm{~mm}$ ( 0.43 of conch diameter). The siphuncle is centrally positioned, with a septal perforation of $0.9 \mathrm{~mm}$ at a diameter of $7 \mathrm{~mm}$ ( 0.13 of conch diameter).

The juvenile specimen, PMU 26664, has a diameter of 2.2-3 mm and a length of $13 \mathrm{~mm}$ (angle of expansion is slightly curved and less pronouncedly annulated; Fig. 12C).

The internal characters are well preserved in specimen PMU 26681 (Figs 13B, 14A), which is a portion of a phragmocone with a diameter increasing from 7.5 to $9 \mathrm{~mm}$ and a length of $16 \mathrm{~mm}$. The chamber height at the adoral end of this fragment is $3 \mathrm{~mm}$ ( 0.3 of corresponding conch diameter), and the distance of the siphuncle is $3.8 \mathrm{~mm}$ (SPR 0.42). In specimen PMU 26661 the siphuncle is relatively well-preserved. There the siphuncle is nearly tubular and the septal necks are orthochoanitic (Fig. 13C).

\section{Remarks}

The larger number of specimens at the PMU permit an evaluation of conch variability and an estimation of the adult size of this species. Based on these new data, the specimen figured in Kröger \& Isakar (2006: figs 7q, 10h) from the Vormsi Regional Stage of Hiiumaa Island, Estonia, must be assigned to Striatocycloceras isbergi $\mathrm{sp}$. nov. It differs from the type specimen of $S$. foerstei in its smaller size and its more numerous, more sharply crested annuli. In this, it lies within within the range of variability of the specimens of $S$. isbergi sp. nov. from the Boda Limestone.

\section{Comparison}

This species is unique with regard to its narrow annulation. The otherwise similar S. foerstei differs in having six to seven annulations per distance equal to conch diameter and a significantly larger adult size.

\section{Stratigraphic and geographic range}

Vormsi Regional Stages, Estonia (Kröger \& Isakar 2006); Boda Limestone, Siljan District, Sweden, late Katian, Ordovician.

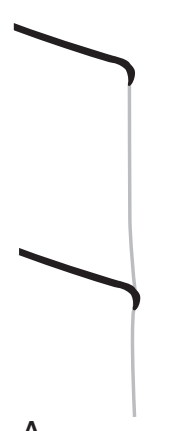

A

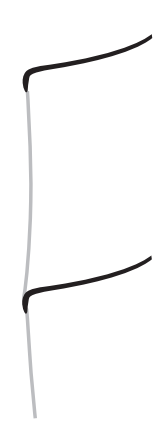

B

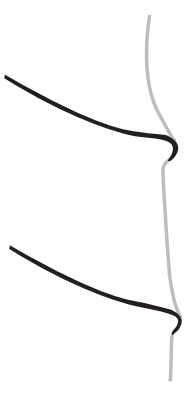

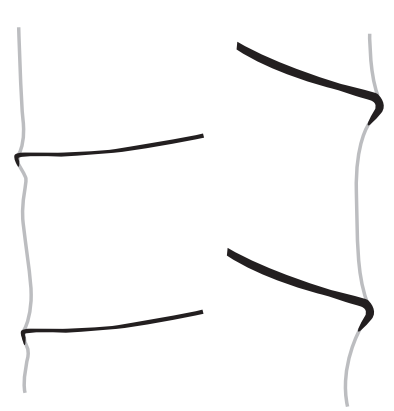

C

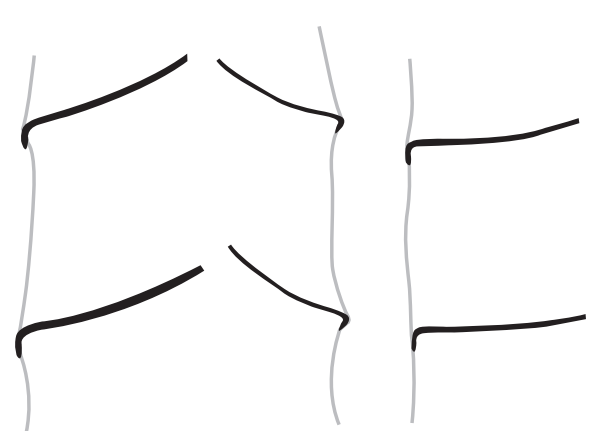

D

Fig. 14. Reconstructions of the details of the septal necks and siphuncular segments of Orthocerida of the Boda Limestone. Note the different septal thicknesses. A. Striatocycloceras isbergi sp. nov., PMU 26681, Kallholn. B. Dawsonoceras fenestratum (Eichwald, 1860), PMU 26706, Kallholn. C. Pleurorthoceras osmundsbergense sp. nov., NRM-PZ Mo 150102c, Osmundsberget. D. Isorthoceras angelini sp. nov., PMU 26784, Kallholn. 


\section{Striatocycloceras? sp.}

Fig. 15

\section{Material}

One specimen: PMU 26699, Kallholn, Siljan District, Sweden; Boda Limestone.

\section{Description}

The $90 \mathrm{~mm}$ long shell fragment consists in part of a body chamber. The maximum width of the fragment is $57 \mathrm{~mm}$, from which a conch of ca. $70 \mathrm{~mm}$ in diameter may be reconstructed, based on the cross section. The conch was slightly curved and annulated with prominent, directly transverse annuli. The distance between the annuli is $10-15 \mathrm{~mm}$, with a tendency to decrease toward the aperture (ca. $0.14-0.2$ of conch cross section; seven to five chambers in a distance equal to the corresponding cross section). The shell surface is ornamented by narrowly, irregularly spaced distinctive growth lines (ca. 4 per one millimeter; Fig. 15). Additionally, on the inner surface of the shell, fine inconspicuous longitudinal lirae are visible (ca. one per millimeter).
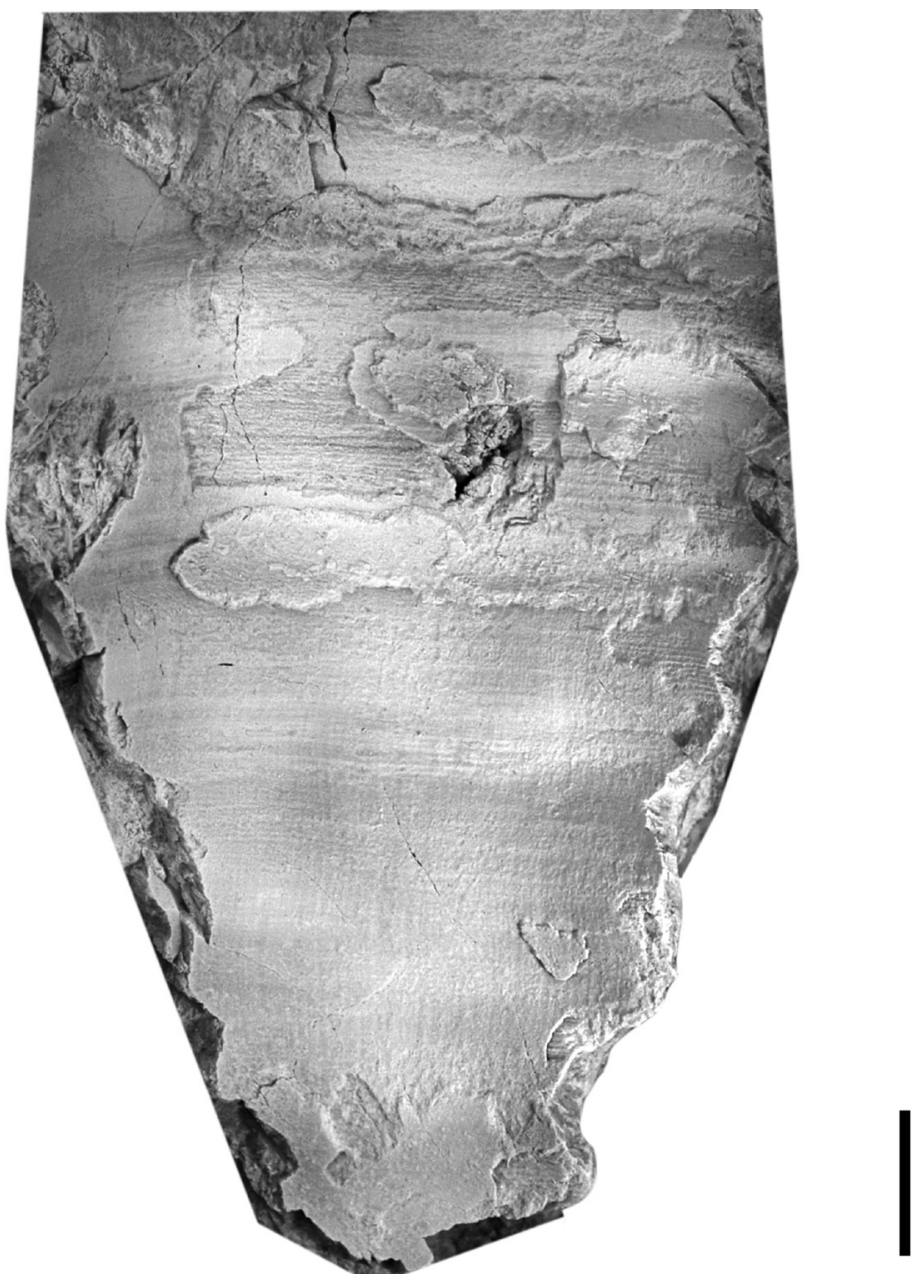

Fig. 15. Fragments of the outer shell and negative shell impression of Striatocycloceras? sp., PMU 26699, Kallholn, Boda Limestone. Scale bar $=10 \mathrm{~mm}$. 


\section{Remarks}

This orthoconic shell fragment is only provisionally assigned within Striatocycloceras. Nothing is known about the internal characters of this specimen. This generic identification is solely based on the annulated orthoconic shell, which is additionally transversally striated, a feature that is known exclusively from Striatocycloceras in the Late Ordovician beds of Baltoscandia.

Family Dawsonoceratidae Flower, 1962

Genus Dawsonoceras Hyatt, 1884

\section{Type species}

Orthoceras annulatum Sowerby, 1816, Wenlock Series, Coalbrookdale, Shropshire, England; by original designation.

\section{Diagnosis}

Slender, circular or slightly compressed orthocones with symmetrically curved septa and straight transverse sutures; sutures parallel to the annulations in each groove of the annulations; annulations regularly spaced, with fine transverse ornamentation or growth lines; growth lines in some species festooned. In some species with longitudinal ridges that may form nodes at the ridges of the annulations; siphuncle subcentral in early growth stages, central in late growth stages, narrow, but expanded within the chambers; septal necks short suborthochoanitic to achoanitic. Incipient annulosiphuncular deposits.

\section{Remarks}

The diagnosis is adopted from Kröger \& Isakar (2006). There the genus was revised and discussed in detail.

Dawsonoceras fenestratum (Eichwald, 1860)

Figs 13A, 14B, 16A-B

Cycloceras fenestratum Eichwald, 1860: 1231, 1232, pl. 48: 14a-b.

Dawsonoceras fenestratum - Kröger \& Isakar 2006: 156, figs 8b, 10b, 12c, f-g (with synonymy). Kröger 2007: 597.

\section{Diagnosis}

Dawsonoceras with angle of expansion of less than ten degrees in juvenile stages. Tubular adult body chamber has diameter of approximately $25 \mathrm{~mm}$; five to six annulations occur at distance similar to shell diameter; approximately 20 longitudinal lirae occur around shell circumference, approximately fifteen growth lines or transverse striae occur per cycle of annulations; septal necks achoanitic; siphuncle subcentral, expanded within chambers. Mural and hyposeptal cameral deposits are known. (Adopted from Kröger \& Isakar 2006.)

\section{Type locality and horizon}

Mõnuste (Kirna), western Estonia, Late Ordovician.

\section{Material examined}

Two specimens, PMU 26700 and 26701, Osmundsberget, Siljan District; fifteen specimens (PMU 26702-26716), Kallholn, Siljan District; all from the Boda Limestone, Boda Core Member, late Katian. 


\section{Description}

The external characters were described in detail by Kröger and Isakar (2006; see also Figs 16A-B). In specimen PMU 26706 additional details of the siphuncle are preserved. Specimen PMU 26706 is a fragment of a phragmocone with a diameter of $18-21 \mathrm{~mm}$ and a length of $28 \mathrm{~mm}$. The chamber distance is relatively constant at ca. $4 \mathrm{~mm}$. The siphuncle is slightly eccentric at the adoral end and ca. $8 \mathrm{~mm}$ distant from the conch margin (SPR 0.38). The siphuncular diameter is $1.3 \mathrm{~mm}$ at the adapical end ( 0.07 of the corresponding conch cross section); there the septal perforation is only $0.8 \mathrm{~mm}$ wide. The siphuncular segments are barrel-shaped; rapidly increasing in diameter close to the septal perforation, the side directed toward the conch center bends inward slightly, forming a shallow concave connecting ring segment (Figs 13A, 14B). The asymmetrical shape of the connecting ring was noted in material previously described by Kröger \& Isakar (2006). The septal necks are short and suborthochoanitic. Shallow hyposeptal deposits occur at the adapical five chambers.

\section{Remarks}

This species was revised by Kröger \& Isakar (2006) and its main features were described based on specimens from the Porkuni Formation of Estonia. Here, additional data regarding the variation of the external characters and features of the siphuncle are noted. The occurrence of hyposeptal cameral
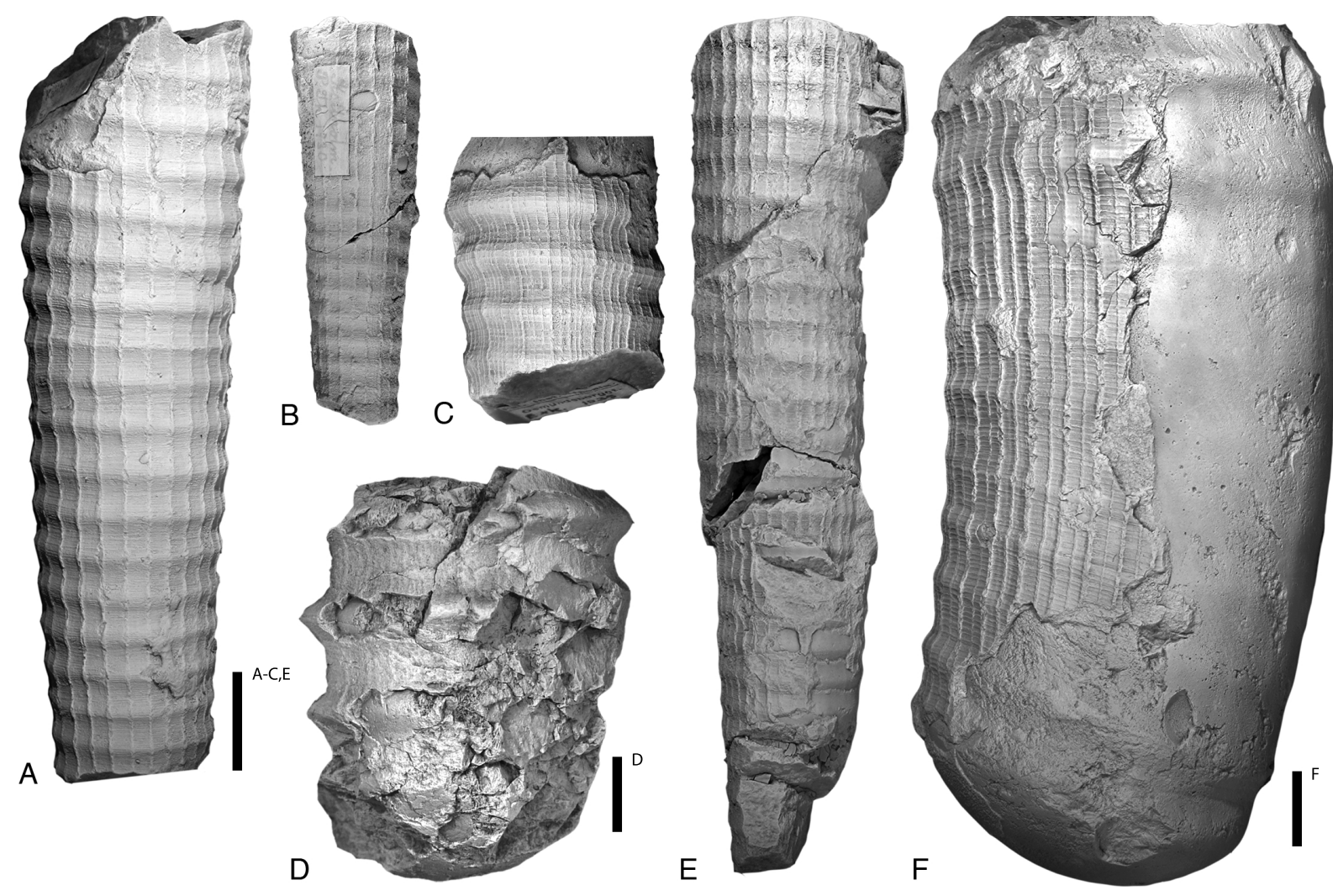

Fig. 16. Dawsonoceratidae and Proteoceratidae of the Boda Limestone. A-B. Dawsonoceras fenestratum (Eichwald, 1860), Kallholn. A. PMU 26702, nearly mature specimen with adorally decreasing angle of expansion. B. PMU 26712, juvenile specimen. C. Gorbyoceras sp. A, PMU 26772, Osmundsberget. D. Goryboceras sp. B, PMU 26773, Kallholn. E. Dawsonoceras stumburi sp. nov., PMU 26717, holotype, Kallholn. F. Gorbyoceras alternestriatum (Strand, 1934) comb. nov., PMU 26771, Unskarsheden. Scale bars: A-C, $\mathrm{E}=10 \mathrm{~mm}$; $=10 \mathrm{~mm} ; \mathrm{F}=10 \mathrm{~mm}$. 
deposits in specimens of Dawsonoceras fenestratum (Eichwald, 1860) from the Boda Limestone (see below) is included within the diagnosis herein.

The conch measurements reveal a clear tendency of a decrease in angle of expansion with increasing conch diameter (Kröger \& Isakar 2006). The mature body chamber of $D$. fenestratum is nearly tubular, whereas in juvenile conchs the maximum expansion reaches $10^{\circ}$ (PMU 26708 with cross section diameters of 9-14 mm; compare Fig. 16A-B). This is in agreement with the measurements listed by Kröger \& Isakar (2006). Additionally, the relative distance of the transverse annuli is highly variable, but lacks a clear ontogenetic trend and varies between 0.16 and 0.3 of the corresponding conch diameter (mean $0.25, \mathrm{n}=12$ ). The number of longitudinal lirae is fixed in each specimen, but varies among different specimens from 20 to 31 .

These external features are well within the range of variability of the Trenton dawsonoceratid Orthoceras beauportense Whiteaves, 1898, from which the internal characters are unknown. It is probable that this species should be synonymized with $D$. fenestratum. Chen \& Zou (1984) reported a similar species from the late Katian Sheshan Formation of North China, which they assign to Anaspyroceras beauportense (Whiteaves, 1898) but provided no details regarding internal characters. This specimen probably should also be assigned to $D$. fenestratum .

\section{Stratigraphic and geographic range}

Nabala/Vormsi Regional Stages, Estonia (questionable, see Kröger \& Isakar 2006); Porkuni Formation, Estonia; Boda Limestone, Siljan District, Sweden; late Katian-Hirnantian, Ordovician.

Dawsonoceras stumburi sp. nov.

urn:1sid:zoobank.org:act:1C1B98BD-F65E-4D72-8A31-203A0730E970

Figs 16E, 17B

Dawsonoceras sp. - Kröger \& Isakar 2006: 157, figs 10e, j, $12 \mathrm{~h}$.

\section{Diagnosis}

Dawsonoceras with angle of expansion of ca. $5^{\circ}$ and circular cross section; ca. five relatively shallow annulations occur at a distance similar to shell diameter; approximately 40 longitudinal lirae occur around shell circumference, more than 10 pronounced transverse striae occur per cycle of annulations; septal necks achoanitic; siphuncle subcentral, fusiform, expanded within chambers.

\section{Etymology}

In honor of Heino Stumbur (Tallinn), an Estonian geologist and paleontologist who first described this form in his unpublished diploma thesis (Stumbur 1955) under the nomen nudum of Spyroceras paulum.

\section{Holotype}

PMU 26717.

\section{Type locality and horizon}

Kallholn, Siljan District, Sweden, Boda Limestone, Boda Core Member, late Katian, Ordovician.

\section{Description}

The holotype is a piece of phragmocone with a length of $72 \mathrm{~mm}$ and a diameter of 14-20 $\mathrm{mm}$ (angle of expansion $5^{\circ}$ ), with a circular conch cross section. The sutures are directly transverse, with a distance of $3 \mathrm{~mm}$ at a diameter of $15 \mathrm{~mm}$ ( 0.2 of corresponding conch cross section; Fig. 16E). The conch is 

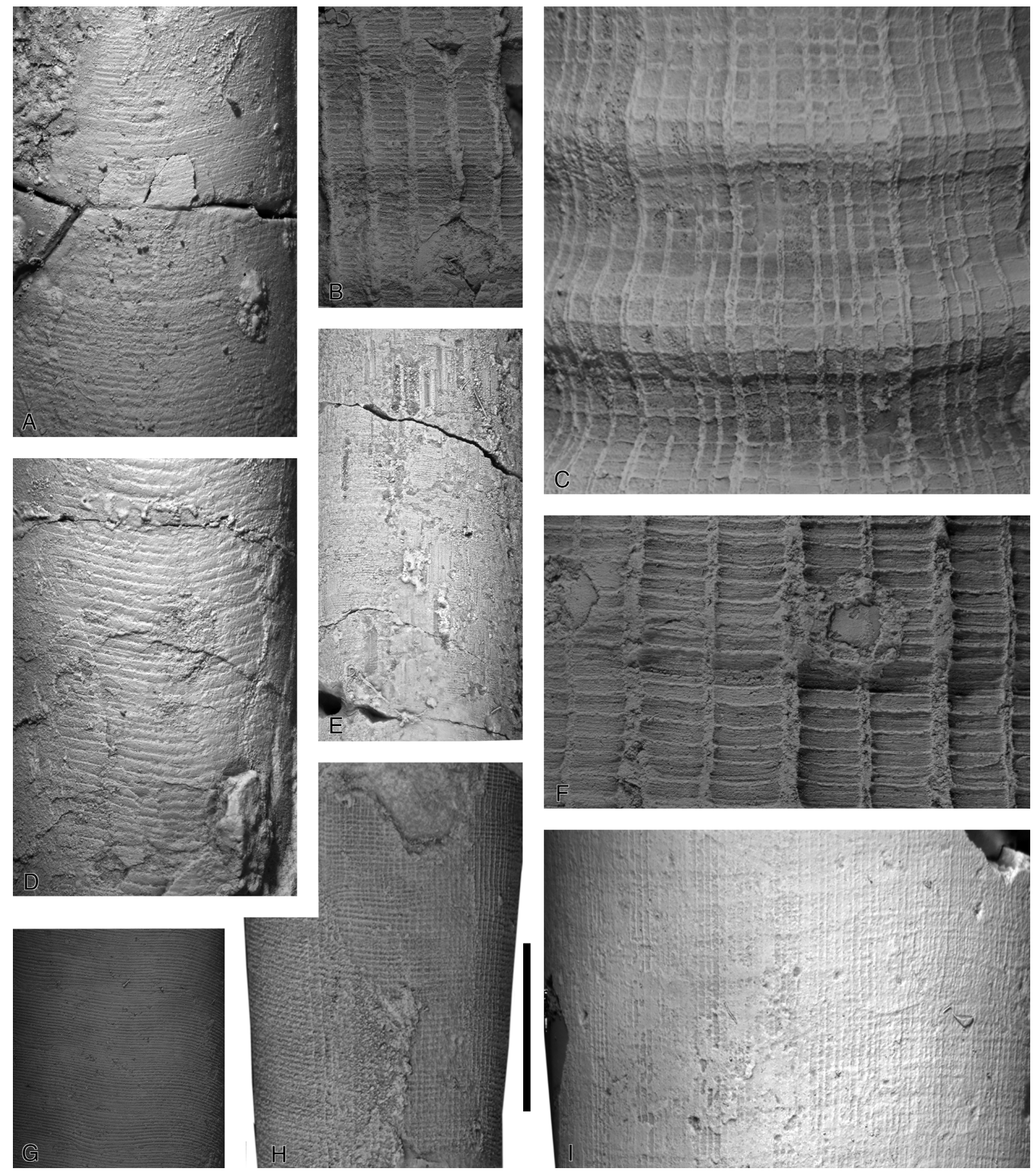

Fig. 17. Shell ornamentation of selected Orthocerida of the Boda Formation. A. Isorthoceras cf. elongatocinctum (Portlock, 1843), PMU 26825, Kallholn, adoral part of the specimen. B. Dawsonoceras stumburi sp. nov., PMU 26717, holotype, Kallholn. C. Gorbyoceras sp. A, PMU 26772, Osmundsberget. D. Isorthoceras cf. elongatocinctum (Portlock, 1843), same specimen as in A, adapical part of specimen. E. Isorthoceras junceum (Hall, 1847), PMU 26834, Kallholn. F. Gorbyoceras alternestriatum (Strand, 1934) comb. nov., PMU 26771, Unskarsheden. G. Isorthoceras curvilineatum sp. nov., PMU 26787, holotype, Osmundsberget. H. Isorthoceras angelini sp. nov., PMU 26774, holotype, Kallholn. I. Isorthoceras suave (Angelin in Angelin \& Lindström, 1880) comb. nov., PMU 26835, Kallholn. Scale $\mathrm{bar}=5 \mathrm{~mm}$ for all figures. 
ornamented with 40 distinctly raised longitudinal lirae around circumference. Additionally, the conch is annulated. The distance between two successive annulations is $3.5 \mathrm{~mm}$ at a corresponding conch diameter of $16 \mathrm{~mm}$ ( 0.22 of distance similar to corresponding conch diameter). Approximately 20 distinct and directly transverse striae occur in a single cycle of annulation (Fig. 17B).

\section{Comparison}

This species differs from $D$. fenestratum in having a higher number of longitudinal lirae (ca. 20-30 in $D$. fenestratum against ca. 40 in D. stumburi sp. nov.). Additionally, the transverse annulation appears to be less pronounced and slightly more widely spaced in $D$. stumburi sp. nov., but the transverse striae are narrower than in D. fenestratum.

The external characters of D. stumburi sp. nov. are identical to those of Orthoceras clathratum Hall, 1847 from the Katian Middleville Formation of New York (see, e.g., Foerste 1928). But a synonymization is at present not possible, as the internal characters of this species are not known.

\section{Stratigraphic and geographic range}

Vormsi Regional Stages, Estonia (Kröger \& Isakar 2006); Boda Limestone, Siljan District, Sweden; late Katian, Ordovician.

Genus Palaeodawsonocerina Kröger \& Isakar, 2006

\section{Type species}

Spyroceras senckenbergi Teichert, 1930, from Lyckholm, Estonia; "Lyckholm stage" of Teichert (1930), Vormsi/Pirgu Regional Stage, late Katian, Late Ordovician.

\section{Diagnosis}

Straight or slightly cyrtoconic, circular or subcircular shell, with prominent, narrowly spaced annulations, growth lines and numerous subordinate filiform longitudinally raised lines, producing a finely reticulate pattern. Siphuncle central or slightly eccentric, slightly expanded, with achoanitic to very short orthochoanitic septal necks. Apex blunt, slightly cyrtoconic, annulated. (From Kröger \& Isakar 2006.)

Palaeodawsonocerina senckenbergi (Teichert, 1930)

Figs 12A, 18C

Spyroceras senckenbergi Teichert, 1930: 280, pl. 5, figs 3, 4.

Palaeodawsonocerina senckenbergi - Kröger \& Isakar 2006: 154, figs 8a, 10i, 12d-e, 12h (with synonymy).

non Spyroceras senckenbergi - Dzik 1984: 122, 125, pl. 35, fig. 5, text-figs 48a, 49.20.

\section{Diagnosis}

Straight, slightly compressed conch with very low apical angle of approximately $1^{\circ}-2^{\circ}$; adult dorsoventral diameter approximately $25 \mathrm{~mm}$; with five to six annulations at a distance that equates to the corresponding shell diameter in adult specimens; annulations straight or very slightly oblique toward the growth direction and regularly spaced; very fine growth lines, about 50 in a cycle of annulation; very fine longitudinal striae or raised lines, about five to seven per millimetre; suture line follows the ridges of the annulations; siphuncle central, slightly expanded within the chambers; septal perforation about 0.07 of the shell diameter. (From Kröger \& Isakar 2006.) 
KRÖGER B., Cephalopods of the Boda Limestone
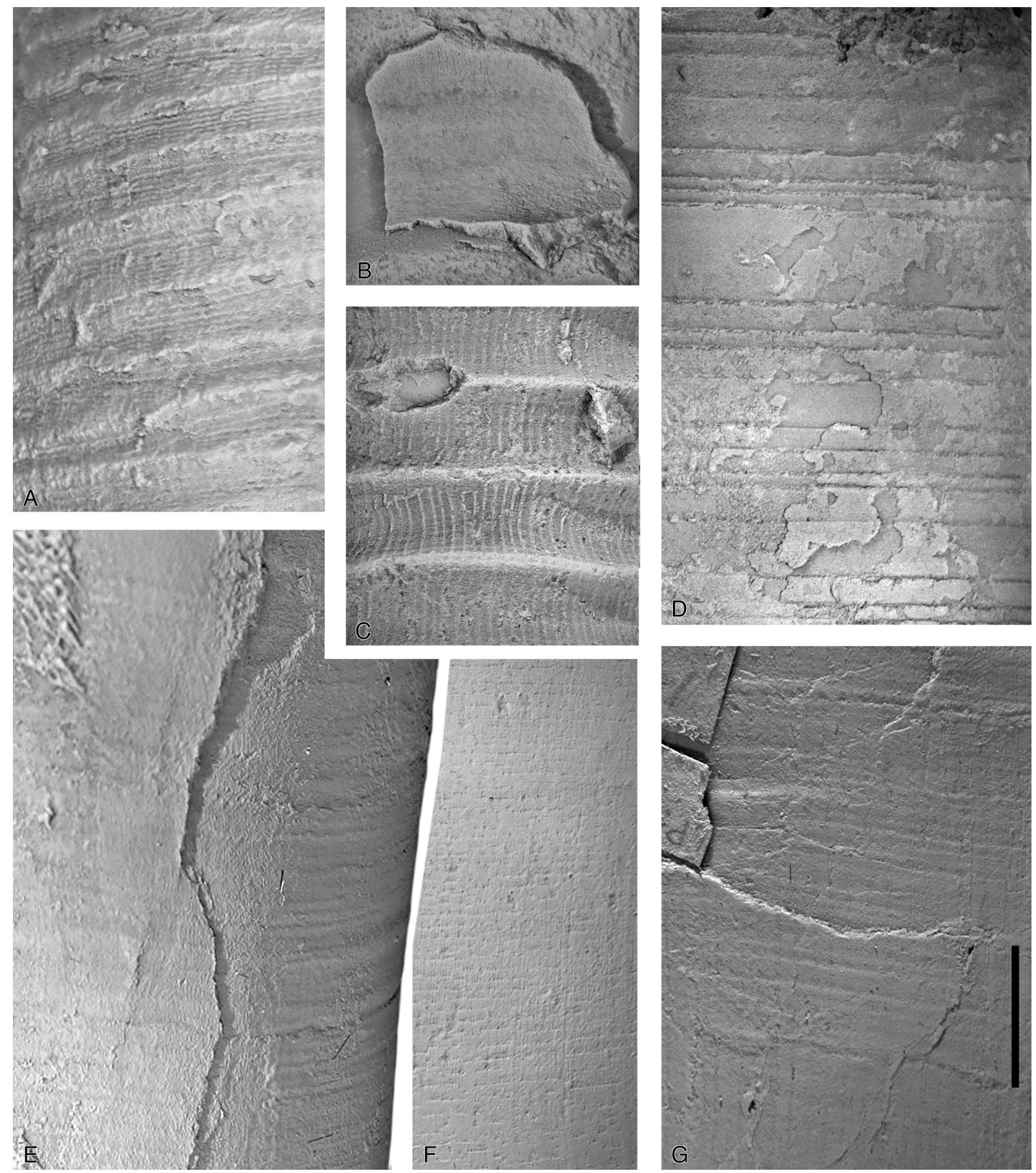

Fig. 18. Shell ornamentation of selected Cephalopoda of the Boda Formation. A. Order, gen. et sp. indet., PMU 26950, Kallholn, lateral view. B. Palaeodawsonocerina? nicolletoides sp. nov., PMU 26727, holotype, Kallholn. C. Palaeodawsonocerina senckenbergi (Teichert, 1930), PMU 26718, Kallholn. D. Geisonoceras wegelini (Angelin in Angelin \& Lindström, 1880) comb. nov., PMU 26745, Unskarsheden. E. Pleurorthoceras osmundsbergense sp. nov., NRM-PZ Mo 150126, holotype, Osmundsberget. F. Warburgoceras longitudinale (Angelin in Angelin \& Lindström, 1880) comb. nov., NRM-PZ Mo 154065, Unskarsheden. G. Redpathoceras depressum sp. nov., PMU 26931, Kallholn. Scale bar $=5 \mathrm{~mm}$ for all figures. 


\section{Type locality and horizon}

Lyckholm, Estonia, "Lyckholm stage" of Teichert (1930), Vormsi/Pirgu Regional Stage, late Katian, Late Ordovician.

\section{Material examined}

Seven specimens (PMU 26718-26724), Kallholn; two specimens (PMU 26725-26726), Osmundsberget, Siljan District, Sweden; all Boda Limestone, Boda Core Member, late Katian, Late Ordovician.

\section{Remarks}

This species was described in detail by Kröger \& Isakar (2006). The material from the Boda Limestone reveals information regarding the ornamentation. PMU 26718 reveals that the annuli are sharply crested and symmetrical in longitudinal cross section (Figs 12A, 18C). The longitudinal ornamentation consists of fine raised lirae, ca. $0.5 \mathrm{~mm}$ apart where the conch diameter is $16 \mathrm{~mm}$. Additional, faint, directly transverse growth lines occur that are more pronounced in mature growth stages. The largest specimen from the Boda Limestone is $25 \mathrm{~mm}$ in diameter (PMU 26724) and supports an earlier assessment (Kröger \& Isakar 2006) that the diameter at maturity of individuals of this species is ca. $25 \mathrm{~mm}$.

\section{Stratigraphic and geographic range}

Keila/Vormsi Regional Stages, Estonia (Kröger \& Isakar 2006); Boda Limestone, Siljan District, Sweden; Katian, Ordovician.

Palaeodawsonocerina? nicolletoides sp. nov. urn:Isid:zoobank.org:act:4E1D7CA7-028A-4174-94DF-D86B525B5F94

Figs 12D-E, 18B

\section{Diagnosis}

Slender, large cyrtocones with a slightly compressed conch cross section and a pronounced annulation; prosiphuncular conch margin wider and more flattened than antisiphuncular margin in cross section; adult conch diameter ca. $30 \mathrm{~mm}$; annuli relatively wide, ca. 4 per distance equal to conch diameter, ridges of annuli sharp and narrow, grooves wider and more rounded; conch surface ornamented with fine longitudinal striae and faint, very shallow, rounded longitudinal ridges; siphuncle eccentric, lying on concave side of conch curvature, septal perforation ca. 0.14 of conch cross section.

\section{Etymology}

The name refers to Orthoceras nicolleti Clarke, 1897, which is very similar to Palaeodawsonocerina? nicolletoides sp. nov. However, this species differs from $O$. nicoletti in having a less centrally positioned siphuncle and a more circular conch cross section.

\section{Type material}

\section{Holotype}

PMU 26727.

\section{Paratype}

One paratype: PMU 26728 from Kallholn, Siljan District, Sweden; Boda Limestone, Boda Core Member, late Katian, Late Ordovician.

\section{Type locality and horizon}

Kallholn, Siljan District, Sweden, Boda Limestone, Boda Core Member, late Katian, Ordovician. 


\section{Description}

Specimen PMU 26728 is a $105 \mathrm{~mm}$ long fragment of a nearly complete curved body chamber, with a diameter that increases from 28 to $32 \mathrm{~mm}$ (angle of expansion $2^{\circ}$; Fig. 12D-E). The conch cross section is nearly circular at the base of the body chamber and slightly compressed at the aperture. The shell is strongly annulate, with a distance between annuli that increases adorally from $7 \mathrm{~mm}(0.24$ of corresponding conch diameter) to $10 \mathrm{~mm}$ ( 0.31 of corresponding conch cross section). The second most adoral of the ridges is significantly lower in amplitude. Generally the ridges of the annuli are sharper than the valleys, which are broadly rounded. The annuli are slightly oblique, inclined adorally on the concave side of the conch curvature.

The holotype (PMU 26727), is a small piece of phragmocone $28 \mathrm{~mm}$ in diameter. The only preserved septum of this specimen is shallow convex (height of curvature $6 \mathrm{~mm}, 0.21$ of conch diameter). The conch cross section is not perfectly circular, but rounded triangular with a pointed antisiphuncular and a broad prosiphuncular side. The septal perforation is $4 \mathrm{~mm}$ wide and eccentrically positioned, with a distance of $10 \mathrm{~mm}$ from the conch margin (SPR 0.36) on the concave side of the conch curvature. The shell is thin, $0.5 \mathrm{~mm}$ in the grooves of the annulation and thickens toward the ridges. The shell surface is ornamented with very fine longitudinal striae (ca. 10 per one millimeter), and very shallow, rounded, inconspicuous longitudinal ridges (Fig. 18B).

\section{Remarks}

The generic assignment of this species is uncertain because only fragments of the mature body chamber are known and internal details are a matter of speculation. However, because the conspicuous ornamentation is characteristic of other species of Palaeodawsonocerina, the species is provisionally assigned to that genus.

\section{Comparison}

The specimens described above are nearly identical to Orthoceras nicolleti from the Platteville Formation, Sandbian-early Katian of Wisconsin (Foerste 1932) with respect to the wide, pronounced annulation and the curvature of the conch. The Platteville specimen is poorly known, as no details of the conch surface are preserved and this is the only known specimen. It differs from Palaeodawsonocerina? nicolletoides sp. nov. in its larger size, central siphuncle and nearly circular conch cross section.

Teichert (1930) assigned a specimen from the Pirgu Regional Stage of Estonia to Syproceras textumaraneum (Roemer, 1861) which can be compared with Orthoceras nicolleti and Palaeodawsonocerina? nicolletoides sp. nov. with regard to its relatively large adult size, curved body chamber and distant annulations. The ornamentation of this specimen is not preserved, casting a degree of uncertainty on Teichert's (1930) assignment to Spyroceras textumaraneum. The specimen of Teichert (1930) differs from Palaeodawsonocerina? nicolletoides sp. nov. in having a narrower and shallower annulation and a larger adult size.

Balashov (1975: pl. 1, figs 3-6) figured several annulated and longitudinally striated orthocerids under the name Gorbyoceras duncanae Flower, 1946. However, conch shape, ornamentation and internal characters indicate that these specimens are better assigned to Palaeodawsonocerina. The ornamentation, annulation and general shell shape of the specimen figured in Balashov (1975: pl. 1, figs 7) is similar to Palaeodawsonocerina? nicolletoides sp. nov., but a direct comparison based on the incomplete material is not possible.

\section{Stratigraphic and geographic range}

Boda Limestone, Siljan District, Sweden; late Katian, Ordovician. 


\author{
Family Eriditidae Chen in Chen et al., 1981 \\ Genus Nathorstoceras gen. nov. \\ urn:Isid:zoobank.org:act:3415D639-EFD4-404C-90EA-DA8AAAA930E5
}

\title{
Type species
}

Nathorstoceras kallholnense gen. et sp. nov., Kallholn, Dalarna, Sweden, Boda Limestone, Boda Core Member, late Katian, Ordovician by montotypy.

\section{Diagnosis}

Straight or slightly curved longicones with annulated or smooth shell, ornamented with transverse lirae or conspicuous growth lines, which form shallow sinus on prosiphuncular side; septal spacing relatively narrow with ca. five chambers per distance equal to corresponding conch diameter; siphuncle subcentral or slightly eccentric on convex side of conch curvature; septal foramen narrow; siphuncular segments abruptly expanded at septal foramen, septal necks achoanitic; epi- and hyposeptal deposits present; endosiphuncular deposits not known at present.

\section{Etymology}

In honour of Alfred Gabriel Nathorst (1850-1921), Swedish palaeobotanist, geologist, and polar researcher, for his pioneering work on the Palaezoic of the Siljan structure (Nathorst 1885).

\section{Comparison}

This genus is unique among Ordovician orthocerids. The rapidly expanding siphuncular segments are similar as compared with late Palaeozoic pseudorthocerids, such as Adnatoceras Flower, 1939. However, characteristic pseudorthocerid endosiphuncular deposits are not known from specimens of Nathorstoceras gen. nov. With its annulate conch $N$. kallholnense sp. nov. resembles Mid Silurian paraphragmitids, which differ in having less expanded siphuncles and suborthochoanitic septal necks. In the Estonian Porkuni Formation smooth orthocones occur, with achoanitic septal necks and broadly expanded siphuncular segments (Eriditidae gen. et. sp. indet. in Kröger 2007). These specimens are poorly preserved or very fragmentary, and it is difficult to compare them with the relatively large fragments of the specimens from the Boda Limestone, but their similarity in the septal neck/siphuncular segment shape suggest that they may represent species of Nathorstoceras gen. nov.

Monomuchites bacotense Balashov, 1975 from the Molodov Horizon of Podolia is known from a single fragmentary specimen only. However, the polished cross section figured in Balashov (1975: pl. 1, fig. 7) shows a marked similarity with the Boda specimens of Nathorstoceras gen. nov. M. bacotense, differs from the Boda specimen mainly in having a circular conch cross section. Herein, it is interpreted as another species of Nathorstoceras gen. nov.

\section{Species included}

Nathorstoceras kallholnense sp. nov., Nathorstoceras adnatum sp. nov., Nathorstoceras bacotense (Balashov, 1975) comb. nov.

\section{Stratigraphic and geographic range}

Boda Limestone, Dalarna, Sweden, late Katian, Late Ordovician. 

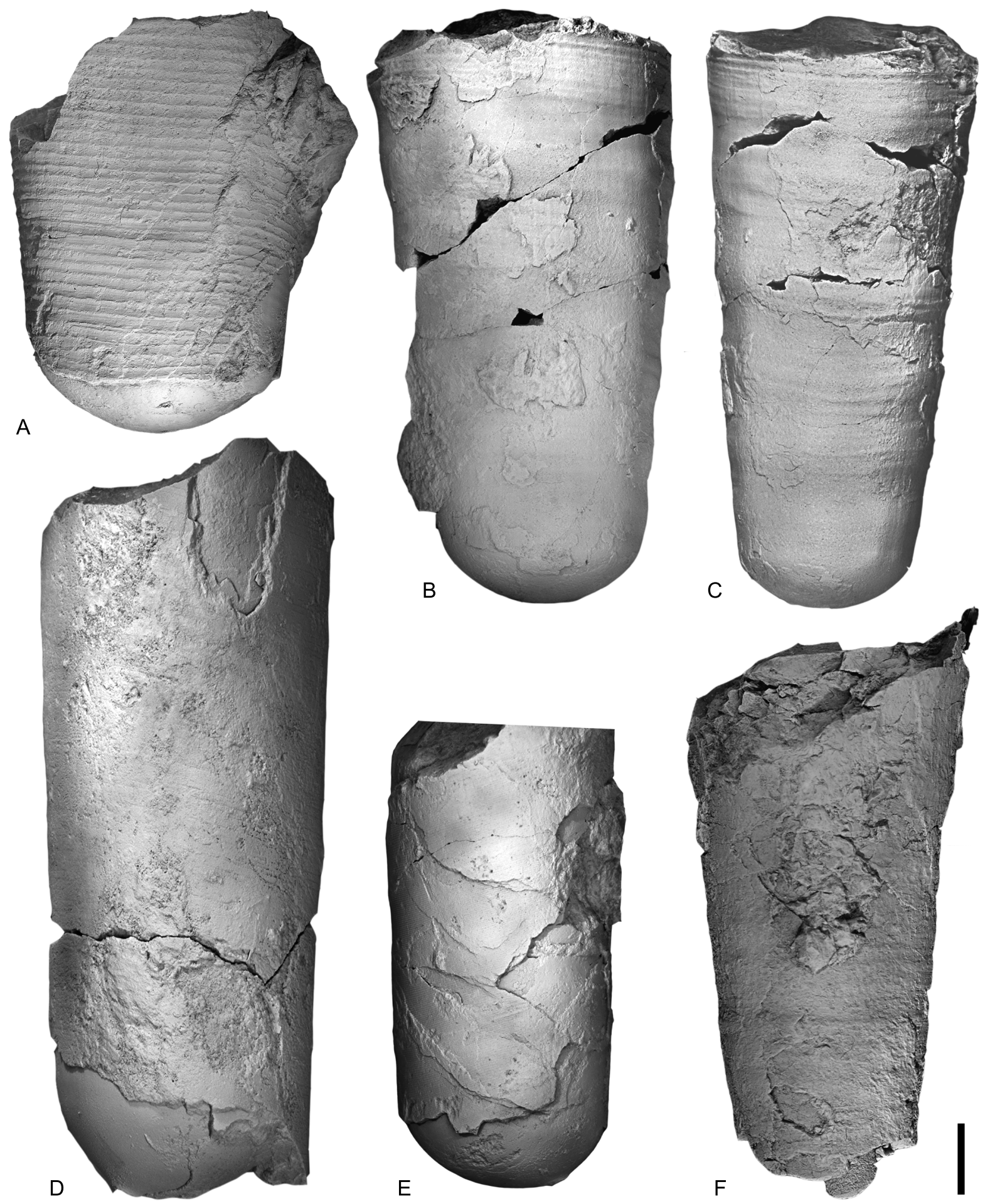

Fig. 19. Orthocerida of the Boda Limestone. A. Nathorstoceras adnatum sp. nov., PMU d1440, holotype, Kallholn, lateral view. B-C. Nathorstoceras kallholnense sp. nov., PMU 26730, Kallholn, complete body chamber. B. Lateral view. C. view from prosiphuncular side. D. Geisonoceras wegelini (Angelin in Angelin \& Lindström, 1880) comb. nov., PMU 26747, Unskarsheden, lateral view. E. Ordogeisonoceras foerstei (Strand, 1934) comb. nov., PMU 26762, Kallholn, lateral view. F. Nathorstoceras kallholnense sp. nov., PMU 26729, holotype, lateral view, note siphuncle on left side. Scale bar $=10 \mathrm{~mm}$ for all figures. 


\section{Nathorstoceras kallholnense sp. nov. urn:lsid:zoobank.org:act:5393FB9D-6642-4D8D-9F4B-C2C741B7CC57}

Figs 10D, 13E, 19B-C, F, 20B, 21A

\section{Diagnosis}

Nathorstoceras gen. nov. with slightly curved annulated conch; angle of expansion of $10-13^{\circ}$; annulations more pronounced in late growth stages; shell sculpture of irregularly spaced, pronounced transverse growth lines, less than one millimeter apart; distance between annulations ca. 0.3 of corresponding conch height; annuli and growth lines with shallow sinus on prosiphuncular side; conch cross section compressed; width/height ratio ca. 0.87 ; septal distance ca. 0.3 of corresponding conch height; siphuncle eccentric (SPR ca. 0.3); septal perforation ca. 0.07 of corresponding conch height; siphuncular segments abruptly expanded at septal foramen with maximum diameter ca. 0.14 of conch diameter; epi- and hyposeptal deposits present; endosiphuncular deposits not known.

\section{Etymology}

Refers to the type locality.

\section{Type material}

\section{Holotype}

PMU 26729.

\section{Paratypes}

Four paratypes: PMU d1376, 26730-26732, from Kallholn, Siljan District, Sweden; all Boda Limestone, Boda Core Member, late Katian.

\section{Type locality and horizon}

Kallholn, Siljan District, Sweden, Boda Limestone, Boda Core Member, late Katian, Ordovician.

\section{Description}

The holotype is a piece of phragmocone ca. $60 \mathrm{~mm}$ long, a height of $27-33 \mathrm{~mm}$ and a width at the adoral end of $33 \mathrm{~mm}$ (width/height ratio 0.87 , angle of expansion $10.4^{\circ}$ ) (Figs $10 \mathrm{D}, 19 \mathrm{~F}$ ). The conch is weakly annulated with a distance between two successive annuli ca. 0.3 that of the corresponding conch cross section, and ornamented with pronounced, irregularly spaced growth lines or raised bands, each with a width of less than a millimeter. The conch is slightly crushed, and nearly straight, with an eccentrically positioned siphuncle. Because of the fragmented shell the siphuncle appears to be positioned on the convex side of the shell curvature. A reconstruction of the shell indicates that the siphuncle is on the convex side of a very slightly curved phragmocone. At the apical end of the specimen the distance of the siphuncle from the conch margin is $9 \mathrm{~mm}$ (SPR 0.33). The siphuncle is much wider than the septal perforation, and at the adapical end of the specimen the septal perforation is ca. $1.8 \mathrm{~mm}$, and the maximum diameter of the siphuncle is $3.5 \mathrm{~mm}(0.07$ and 0.13 of the corresponding conch cross section, respectively) (Figs 20B, 21A). The septa are $9 \mathrm{~mm}$ apart where the corresponding conch height is 30 $\mathrm{mm}$. The septal necks are achoanitic and siphuncular segments (connecting rings) are abruptly expanded at the septal foramen. At the adapical end of the specimen epi- and hyposeptal deposits occur.

Specimen PMU 26730 is a fragment of a body chamber with a length of $72 \mathrm{~mm}$, a height of 29-44 $\mathrm{mm}$, and a width of 26-38 mm (width/height ratio 0.86-0.89, angle of expansion $11.8^{\circ}$ ) (Fig. 19B-C). The conch cross section is elliptical, with the antisiphuncular side slightly more sharply rounded. The conch is annulated with rounded, shallow annuli $12 \mathrm{~mm}$ apart at a corresponding conch height of 40 $\mathrm{mm}$. In addition, pronounced, irregularly spaced growth lines run parallel to the annuli, both of which are slightly oblique and form a shallow sinus on the prosiphuncular side of the conch. The siphuncle is 

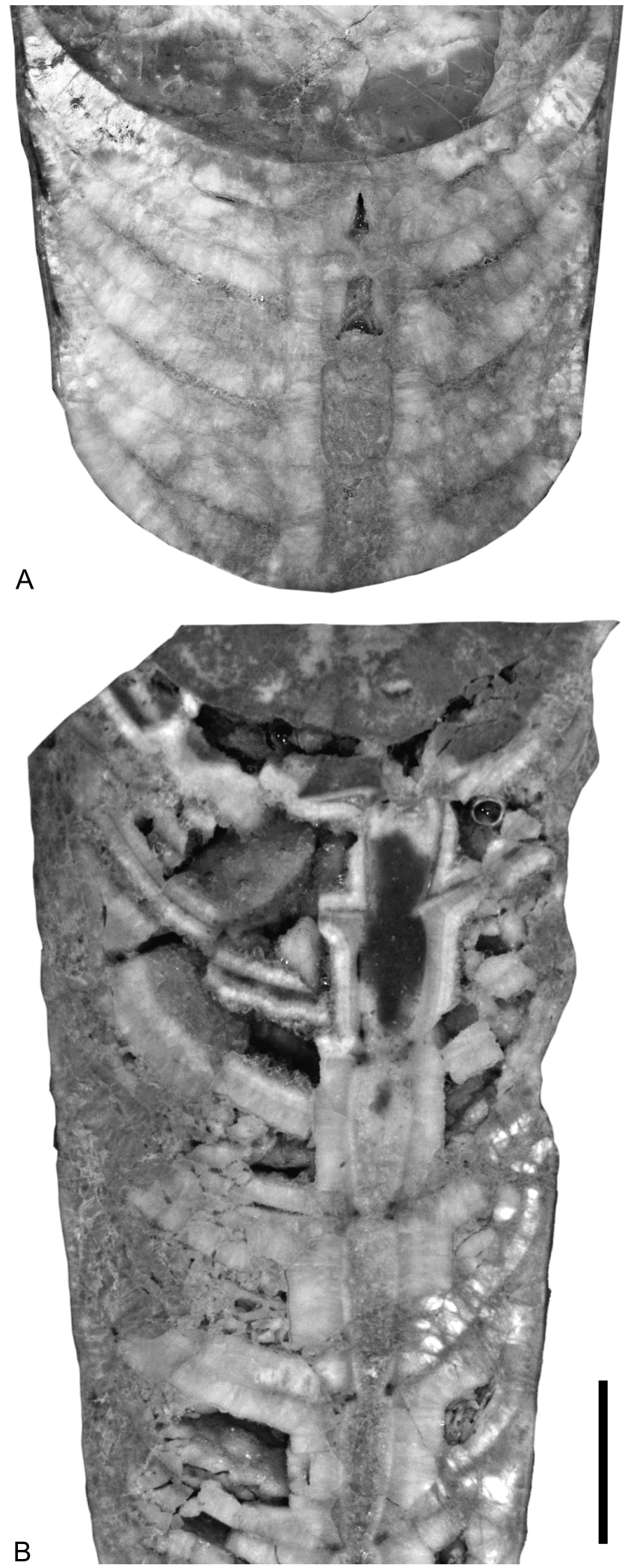

Fig. 20. Polished median sections of Nathorstoceras sp. nov., Kallholn, Boda Limestone. A. Nathorstoceras adnatum sp. nov., PMU 26733, holotype, Kallholn. B. Nathorstoceras kallholnense sp. nov., PMU 26729, holotype, Kallholn. Scale bar $=10 \mathrm{~mm}$ for both figures. 
eccentric (SPR 0.28), lying on the convex side of the conch curvature. Specimen PMU 26731, which is a part of a phragmocone and body chamber, is the largest specimen of this species with a maximum conch height of ca. $60 \mathrm{~mm}$.

\section{Comparison}

Nathorstoceras kallholnense sp. nov. differs from $N$. adnatum sp. nov. in having a more pronounced annulated conch and a less compressed conch cross section.

\section{Stratigraphic and geographic range}

Boda Limestone, Dalarna, Sweden, late Katian, Late Ordovician.

Nathorstoceras adnatum sp. nov. urn:1sid:zoobank.org:act:58064C88-D4A3-4CA4-B6EA-DE719EE0F724

Figs 10C, 13F, 19A, 20A, 21B

\section{Diagnosis}

Nathorstoceras with nearly straight and very weakly annulated conch with angle of expansion of $8^{\circ}$; annulations more pronounced in late growth stages; shell ornamented with regularly spaced transverse lirae and distance between annulations ca. 0.2 of corresponding conch height; annuli and lirae form shallow sinus on prosiphuncular side; conch cross section compressed with width/height ratio of ca. 0.8; septal distance ca. 0.24 of corresponding conch height; siphuncle subcentral with SPR 0.41; septal perforation with diameter of ca. 0.05 of corresponding conch height; siphuncular segments abruptly expanded at septal foramen with maximum diameter of ca. 0.14 of corresponding conch cross section; endosiphuncular deposits unknown.

\section{Etymology}

Refers to the strongly expanded, adnate siphuncular segments of this species.

\section{Holotype}

PMU 26733.

\section{Type locality and horizon}

Kallholn, Siljan District, Sweden, Boda Limestone, Boda Core Member, late Katian, Ordovician.

\section{Description}

The specimen is a portion of phragmocone ca. $50 \mathrm{~mm}$ long, with a height of $37-44 \mathrm{~mm}$ and a width at the adoral end of $30 \mathrm{~mm}$ (width/height ratio 0.81, angle of expansion $8^{\circ}$ ) (Fig. 10C, 19A). The conch is faintly annulated with a distance between two successive annuli of ca. 0.2 of the corresponding conch cross section, and ornamented with pronounced, regularly spaced lirae, with a distance between two subsequent lirae of ca. $1.5 \mathrm{~mm}$. The conch is is nearly straight, with a subcentrally positioned siphuncle; at the apical end of the specimen its distance from the conch margin is $15 \mathrm{~mm}$ (SPR 0.41). The connecting ring is much wider than the septal perforation (Figs 20A, 21B). At the adapical end of the specimen the septal perforation is ca. $2 \mathrm{~mm}$ and the maximum diameter of the siphuncle is $5 \mathrm{~mm}(0.05$ and 0.14 of the corresponding conch cross section, respectively). The sutures are directly transverse and form shallow lateral lobes. At the adapical end of the specimen the distance between two septa is $9 \mathrm{~mm}(0.24$ of corresponding conch cross section). The septal necks are achoanitic and the siphuncular segments are adnate, abruptly expanded at septal foramen. No cameral and endosiphuncular deposits occur. 


\section{Comparison}

See comparison with Nathorstoceras kallholnense sp. nov. (above).

Family Geisonoceratidae Zhuravleva, 1959

Genus Geisonoceras Hyatt, 1884

\section{Type species}

Orthoceras rivale Barrande, 1866, Prague Basin, Czech Republic, Ludlovian, Silurian; by original designation.

\section{Diagnosis}

Slender longiconic orthocones or slightly cyrtoconic longicones with circular to subcircular cross section; ornamented with broad transverse bands between which are fine growth lines; transverse bands are slightly oblique forming shallow hyponomic sinus; sutures directly transverse or slightly
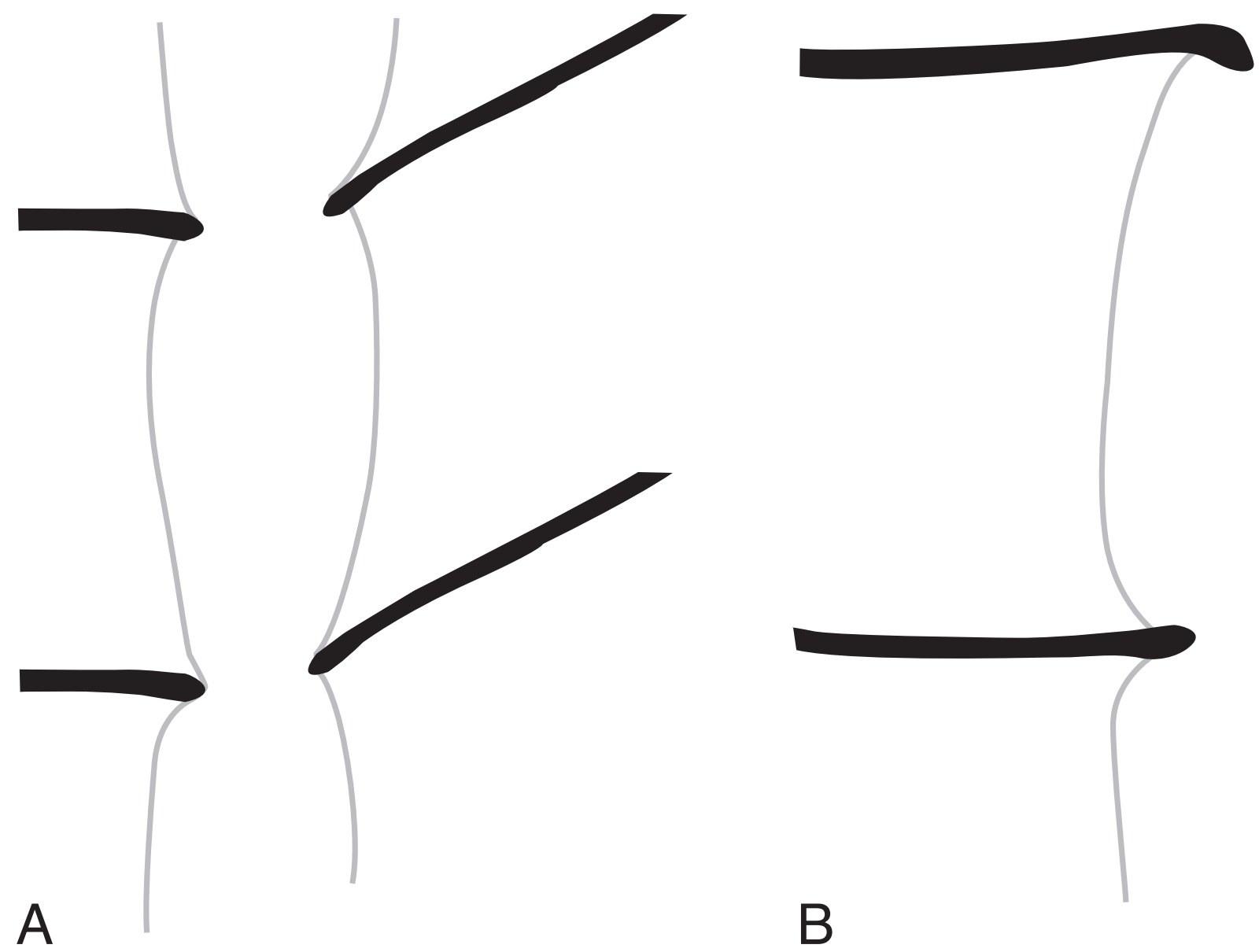

Fig. 21. Reconstruction of the details of the septal necks and connecting ring of Nathorstoceras sp. nov., Kallholn, Boda Limestone. A. Nathorstoceras kallholnense sp. nov., PMU 26729, holotype. B. Nathorstoceras adnatum sp. nov., PMU 26733, holotype. 
oblique; siphuncle subcentral; septal necks short orthochoanitic; connecting rings slightly expanding within chambers; weak annulosiphonate deposits concentrated at septal foramen in adapical siphuncular segments; camerae with episeptal and hyposeptal deposits. (Adopted from Sweet 1964c).

Geisonoceras wegelini (Angelin in Angelin \& Lindström, 1880) comb. nov.

Figs 2, 13I, 18D, 19D, 22

Orthoceras wegelini Angelin in Angelin \& Lindström, 1880: 5, pl. 6, fig. 6.

Orthoceras saksbyense Teichert, 1930: 277, pl. 5, fig. 2.

\section{Diagnosis}

Slender orthocones with angle of expansion of ca. $5^{\circ}$ or less, circular or slightly compressed conch cross section; chamber height of ca. $0.3-0.5$ of distance similar to corresponding cross section diameter; ornamented with obliquely transverse, irregularly spaced growth bands; distance between growth bands $0.3-3 \mathrm{~mm}$; siphuncular position eccentric (SPR ca. 0.2); siphuncular segments tubular, short orthochoanitic to suborthochoanitic septal necks; weakly developed annulosiphuncular deposits are restricted to the position of the septal necks; hypo- and episeptal deposits occur.

\section{Type material}

\section{Lectotype}

NRM Mo 152346 (designated herein).
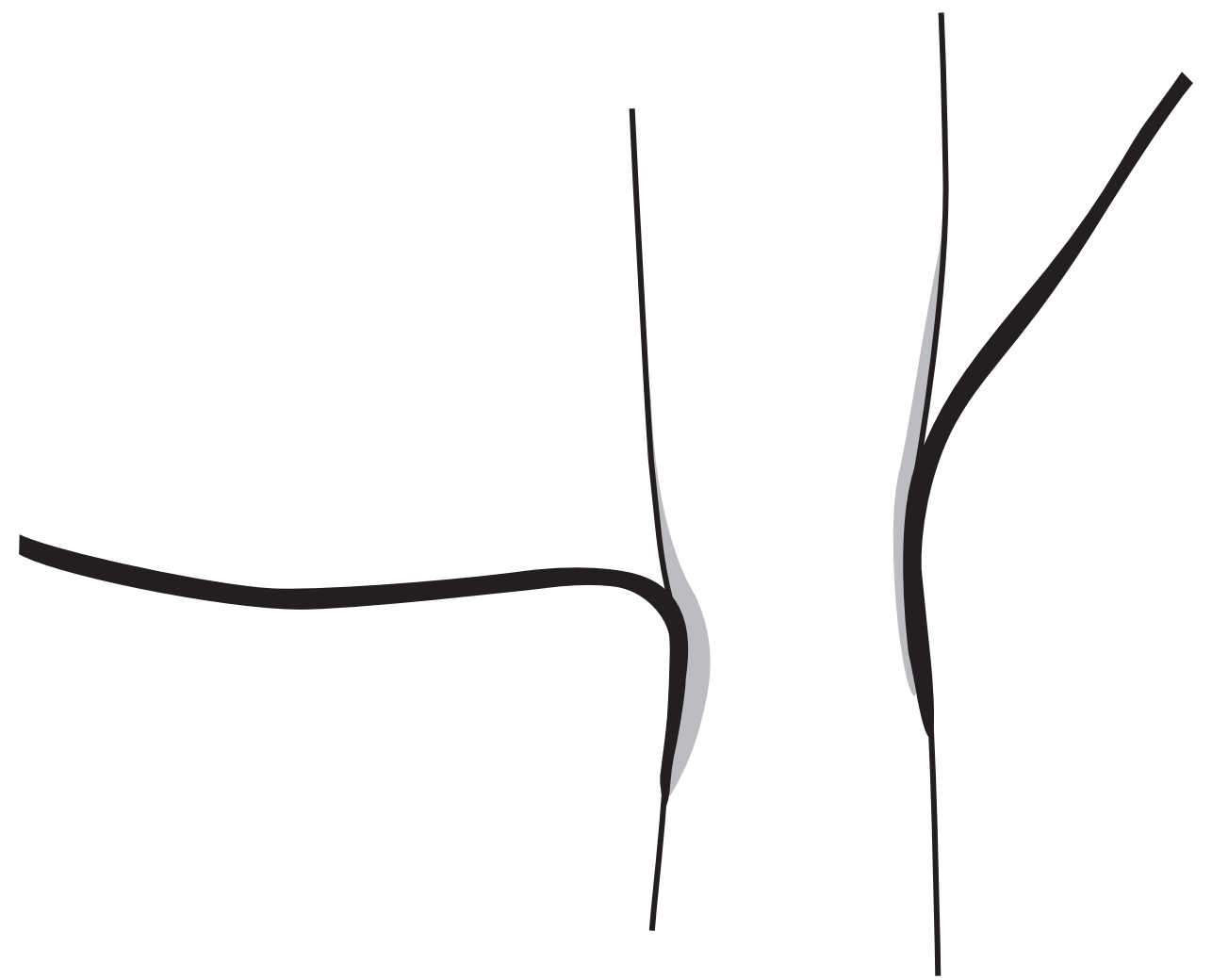

Fig. 22. Geisonoceras wegelini (Angelin in Angelin \& Lindström, 1880) comb. nov., PMU 26740, from Unskarsheden, Boda Limestone. Same specimen as in Fig. 13I. 
KRÖGER B., Cephalopods of the Boda Limestone

\section{Paralectotypes}

Two paralectotypes (NRM Mo 152347, 152348) from Östbjörka, Boda Limestone, latest Katian.

\section{Type locality and horizon}

Östbjörka, Siljan district, Dalarna, Sweden; Boda Limestone, Boda Core Member, late Katian, Ordovician.

\section{Other material examined}

Five specimens (PMU 26734-26738) from Kallholn; 19 specimens (PMU 26739-26757) from Unskarsheden, Siljan District; all Boda Limestone, latest Katian.

\section{Description}

The lectotype is a relatively poorly preserved fragment of a phragmocone with an angle of expansion which cannot be measured exactly because of this fragmentary status. It agrees with respect to conch ornamentation, general conch shape and position of the siphuncle with the specimen PMU 26747.

Specimen PMU 26747 is a well preserved portion of phragmocone $83 \mathrm{~mm}$ long, with a slightly compressed section (ratio width/height 0.93 ), and a conch height of 43-49 $\mathrm{mm}$ (angle of expansion $4.1^{\circ}$ ) (Figs 2, 19D). The conch surface is ornamented with irregularly spaced bands with fine deep grooves in between. Bands and grooves are parallel to each other. The distance between the grooves varies between 0.2 and $0.3 \mathrm{~mm}$ in this specimen (Fig. 18D). The bands are oblique, forming a shallow sinus on the prosiphuncular side. At the apical end of the specimen, the siphuncle is positioned at ca. $9 \mathrm{~mm}$ from the conch margin (SPR 0.21). There the siphuncular perforation is $4 \mathrm{~mm}$ wide (ca. 0.09 of corresponding conch height). The most adapical septum is moderately convex with a height of curvature of ca. $10 \mathrm{~mm}$ ( 0.23 of corresponding conch height).

The mean of the angle of expansion of eight measured specimen is ca. $4.2^{\circ}$ (minimum $2.19^{\circ}$, maximum $\left.5.19^{\circ}\right)$. The eccentricity of the siphuncle is relatively constant; in three measured specimens it varies between a SPR of 0.17 to 0.22 .

The largest specimen, PMU 26752, with a cross section diameter of $92 \mathrm{~mm}$, possesses a pronounced constriction on the cast of the body chamber at ca. $35 \mathrm{~mm}$ adapically of the adoral end of the fragment.

The shape of the siphuncle and septal neck is preserved in specimens PMU 26745 (Fig. 18D), 26740 (Figs 13I, 22), 26741 and 26746. These fragments have conch diameters between 24 and $58 \mathrm{~mm}$. In all five specimens the siphuncle is nearly tubular, very slightly constricted at the position of the septal perforation and the septal necks are short orthochoanitic to suborthochoanitic, with a length of ca. 0.14 of the length of the siphuncular segment (= chamber height). At the position of the septal neck, shallow annulosiphuncular deposits are developed at parts of the septal necks which are directed toward the conch center. Hyposetal, episeptal and mural deposits occur (see, e.g., Fig. 2).

\section{Remarks}

The transverse ornamentation is subdued and visible only in well preserved specimens. In slightly weathered specimens, the conch surface appears perfectly smooth and in steinkerns with high probability it is not preserved. Therefore, poorly preserved specimens could be mistakenly assigned to the smooth Pleurorthoceras. Teichert (1930) described a smooth longicone under the name of Orthoceras saksbyense with exactly the same conch dimensions, shape and distance of septa, position and dimension of siphuncle and septal necks which have no signs of ornamentation. Therefore, with a very high probability this species is conspecific with Geisonoceras wegelini Angelin in Angelin \& Lindström, 1880 comb. nov. and is synonymised with the latter, herein. 


\section{Comparison}

Geisonoceras is a genus which has been widely used as a wastebasket taxon for a variety of straight longicones with a transverse ornamentation. Currently it comprises more than fifty species. Probably, most of them are not closely related to the genotype. G. wegelini comb. nov. is very similar to the genotype with respect to its ornamentation and internal characters; it differs in having a strictly orthoconic shell and only poorly developed annulosiphuncular deposits. The latter may be an artifact, as only relatively large fragments with internal structures preserved are known from $G$. wegelini comb. nov.

\section{Stratigraphic and geographic range}

Vormsi Regional Stages, Estonia (Teichert 1930); Boda Limestone, Siljan District, Sweden; late Katian, Ordovician.

\section{Geisonoceras? sp.}

Fig. $23 \mathrm{H}$

\section{Material}

PMU 26758, from Kallholn, Siljan District, Sweden, Boda Limestone, Boda Core Member, late Katian, Ordovician.

\section{Description}

The specimen represents the juvenile part of a phragmocone $45 \mathrm{~mm}$ long, having a diameter of 5-8.3 $\mathrm{mm}$ (angle of expansion $4.4^{\circ}$ ), and a circular conch cross section. The shell is ornamented with obliquely transverse adorally imbricated striae (Fig. $23 \mathrm{H}$ ). Adorally the conch widens at each stria, which results in an annulated pattern with a sharp ridge at the adoral end of each of them. The distance between two successive striae varies widely from 0.3 to $1.5 \mathrm{~mm}$. At the adoral end a trace of a healed predation additionally causes irregularities in the distance of the transverse elements.

\section{Remarks}

This small specimen might represent the juvenile stage of Geisonoceras wegelini (Angelin in Angelin \& Lindström, 1880) comb. nov. Only relatively large fragments of G. wegelini are known. These fragments are ornamented with obliquely transverse bands with highly irregular spacing. The pattern of ornamentation of G. wegelini comb. nov. resembles that of specimen PMU 26758, but is shallower and not imbricated. Both forms are interpreted as separate species, because intermediate growth stages are not available for further study.

\section{Comparison}

The specimen PMU 26758 differs from known juvenile specimen of Tyrioceras subannulare (Portlock, 1843) (see Evans 1993) and from Imbricatoceras ascendens (Blake, 1882) (see Holland 1993) in having a strongly irregularly spaced transverse ornamentation. Known species of Thyriocerias differ in having a curved and more regularly spaced transverse ornamentation.

Genus Ordogeisonoceras Frey, 1995

\section{Type species}

Orthoceras amplicameratum Hall, 1847 from the Trenton Formation, latest Katian, Middleville, New York, USA. 


\section{Diagnosis}

Slender, gradually expanding orthocones; ornamented with fine longitudinal lirae; circular in cross section with straight, transverse sutures; chamber distance ca. one-half of the corresponding conch
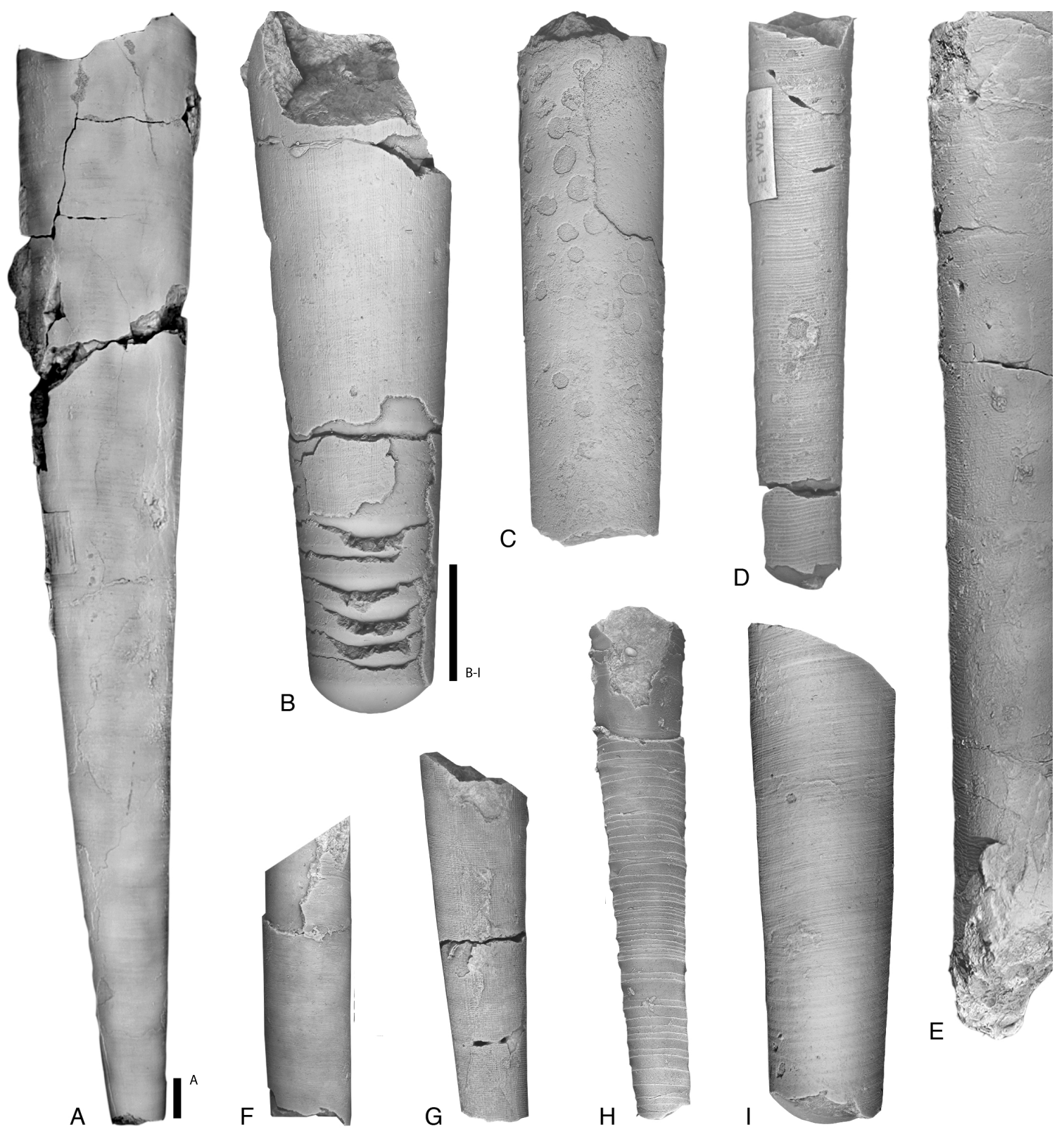

Fig. 23. Orthocerida of the Boda Limestone. A. Pleurorthoceras osmundsbergense sp. nov., NRM-PZ Mo 150126, holotype, Osmundsberget. B. Isorthoceras suave (Angelin in Angelin \& Lindström, 1880) comb. nov.,PMU26835, Kallholn.C.Isorthocerasjunceum(Hall,1847),PMU26833,Kallholn.D-E.Isorthoceras cf. elongatocinctum (Portlock, 1843), Kallholn. D. PMU 26814, juvenile growth stage. E. PMU 26825, larger specimen with irregularly spaced transverse ornamentation. F. Isorthoceras curvilineatum sp. nov., PMU26787, holotype, Osmundsberget. G. Isorthoceras angelini sp. nov., PMU26774, holotype, Kallholn. H. Geisonoceras? sp., PMU 26758, Kallholn. I. Isorthoceras heroyense (Strand, 1934) comb. nov., PMU 26831, Kallholn. Scale bars: A $=10 \mathrm{~mm}$; B-I $=10 \mathrm{~mm}$. 
diameter; siphuncle eccentric; siphuncular segments subtubular, slightly expanded within chambers; siphuncular diameter $0.14-0.2$ of corresponding conch cross section; septal necks moderately long, suborthochoanitic; endosiphuncular deposits consisting of small annuli, restricted to the apical portions of the phragmocone; cameral deposits well developed. (Adopted from Frey 1995.)

\section{Remarks}

In the original diagnosis, the septal necks were described as "orthochoanitic", but this is imprecise; the figures of the type species in Frey (1995: pl. 3, figs 4, 5, 8) indicate suborthochoanitic septal necks.

Ordogeisonoceras foerstei (Strand, 1934) comb. nov. Figs $13 \mathrm{H}, 19 \mathrm{E}$

Geisonoceras foerstei Strand, 1934: 13, pl. 3, fig. 9.

\section{Diagnosis}

Slender orthocones with apical angle less than $5^{\circ}$, slightly compressed to circular conch cross section; ornamented with slightly oblique transverse striae, which are slightly imbricated in direction of growth, distance between lirae variable, but generally less than one millimeter; siphuncle eccentric with SPR of ca. 0.21 ; siphuncle diameter ca. 0.1 of corresponding conch cross section. (Adopted from Strand 1934.)

\section{Type locality and horizon}

Frognøya Island, Ringerike, Norway; exact stratigraphic horizon unknown, Late Ordovician.

\section{Material examined}

One specimen from Unskarsheden, Dalarna (PMU 26759); eight specimens from Kallholn, Dalarna (PMU 26760-26767); all from Boda Limestone, late Katian.

\section{Description}

Specimen PMU 26763 is a portion of phragmocone ca. $50 \mathrm{~mm}$ long, with a conch height of $34-37 \mathrm{~mm}$ (angle of expansion $2.9^{\circ}$ ). The conch surface is ornamented with slightly oblique (angle of ca. $15^{\circ}$ to the normal of the conch axis) transverse lirae with a frequency of ca. 4 per millimeter (Fig. 19E). The lirae slope in adapical direction toward the prosiphuncular side, forming a shallow sinus on the prosiphuncular side. The lirae are rounded and slightly imbricate in an adoral direction. The septa are directly transverse and ca. $20 \mathrm{~mm}$ apart ( 0.54 of corresponding chamber height) with a convexity of $13 \mathrm{~mm}$ (ca. 0.35 of corresponding conch height). The septal necks are orthochoanitic to suborthochoanitic, ca. $3 \mathrm{~mm}$ long (Fig. 13H). The siphuncular diameter is ca. $3.5 \mathrm{~mm}$ at the septal foramen and the connecting rings are nearly tubular. No endosiphuncular or cameral deposits occur.

Amongst the specimens from the Boda Limestone, several are of a relatively large size. The largest fragment, PMU 26760, is a nearly complete fragment of a body chamber with a diameter increasing from 115 to $145 \mathrm{~mm}$ and a length of $444 \mathrm{~mm}$.

The shape of the conch cross section varies slightly between the specimens from circular to slightly compressed (minimum width/height ratio 0.97 ). The position of the siphuncle is highly eccentric in all specimens, but varies between SPRs of 0.13 and 0.25 , with a tendency to shift toward the center during growth. 
The total length of the body chamber of $150 \mathrm{~mm}$ is preserved in specimen PMU 26761, which is $40 \mathrm{~mm}$ in diameter at the last septum and $48 \mathrm{~mm}$ at the aperture (angle of expansion $3.1^{\circ}$ ). In this specimen the distance of the transverse lirae is relatively wide, varying from 0.5 to ca. $0.8 \mathrm{~mm}$.

Details of the siphuncle and septal necks are preserved in specimen PMU 26763 (Fig. 13H); a portion of phragmocone is 35 to $37 \mathrm{~mm}$ in diameter. The septa of this specimen are crushed and only parts of the siphuncle and septal necks are preserved. The septal necks are orthochoanitic at the side directed toward the conch margin and suborthochoanitic at the side directed toward the conch centre and very short (ca. 0.1 of the length of the corresponding siphuncular segment $=$ chamber height). Weak episeptal deposits occur.

\section{Remarks}

The type specimen consists of a body chamber only. The specimens from the Boda Limestone are similar to the type specimen in possessing a slightly oblique, imbricated transverse ornamentation, a similar conch cross section, as well as a similar siphuncle diameter and position. Consequently, they are here assigned to $O$. foerstei comb. nov. The Boda specimens reveal a suborthochoanitic septal neck and a nearly tubular shape of the siphuncle, which are diagnostic characters of Ordogeisonoceras.

\section{Comparison}

The type of the genus differs from $O$. foerstei comb. nov. in having periodically alternating distances between the transverse lirae.

Michelinoceras? expansum Blake, 1882 from the late Katian Killey Bridge of Ireland (Evans 1993) is similar in having a slightly oblique transverse ornamentation with ca. four lirae per one millimeter. It is probably conspecific with $O$. foerstei comb. nov. But the internal characters are too poorly known in order to synonymize $O$. foerste $i$ with this species.

Geisonoceras fustis Barskov, 1980 from the latest Ordovician of Kazakhstan, which is similar in general conch shape and ornamentation, differs in having a centrally positioned siphuncle and shorter, more curved septal necks.

\section{Stratigraphic and geographic range}

Late Ordovician, Ringerike District, Norway (Strand 1934); Boda Limestone, Siljan District, Sweden; late Katian, Ordovician.

\section{Genus Pleurorthoceras Flower, 1962}

\section{Type species}

Orthoceras clarksvillense Foerste, 1924 from the Waynesville Formation, latest Katian of Clarksville, Ohio, USA.

\section{Diagnosis}

Slender, gradually expanding, smooth orthocones; circular in cross section with straight, transverse sutures; chamber distance between one-third to one half of the corresponding conch diameter, siphuncle subcentral to central; siphuncular segments subtubular, slightly expanded within chambers; septal necks short, suborthochoanitic; endosiphuncular deposits unknown; mural cameral deposits well developed. (Adopted from Flower 1962.) 
Pleurorthoceras osmundsbergense sp. nov. urn:1sid:zoobank.org:act:C6C26456-C557-45FD-BBB8-E2BFC1C0300C

Figs 13G, 14C, 18E, 23A, 24

\section{Diagnosis}

Pleurorthoceras with very slightly curved shell, with angle of expansion of ca. $7^{\circ}$, circular conch cross section, and adult diameters of ca. $50 \mathrm{~mm}$; ornamented with fine, inconspicuous, irregularly spaced, slightly oblique growth lines or rounded striae; siphuncle subcentral (SPR ca. 0.46) on convex side of conch curvature. Heavy mural deposits.

\section{Etymology}

Refers to the type locality.

\section{Type material}

\section{Holotype}

NRM Mo 150126.

\section{Paratypes}

Two paratypes: NRM Mo 150102 from Osmundsberget, Dalarna; PMU 26768 from Kallholn, Dalarna, Sweden; all Boda Limestone, Boda Core Member, late Katian.

\section{Type locality and horizon}

Osmundsberget, Siljan District, Sweden, Boda Limestone, Boda Core Member, late Katian, Ordovician.
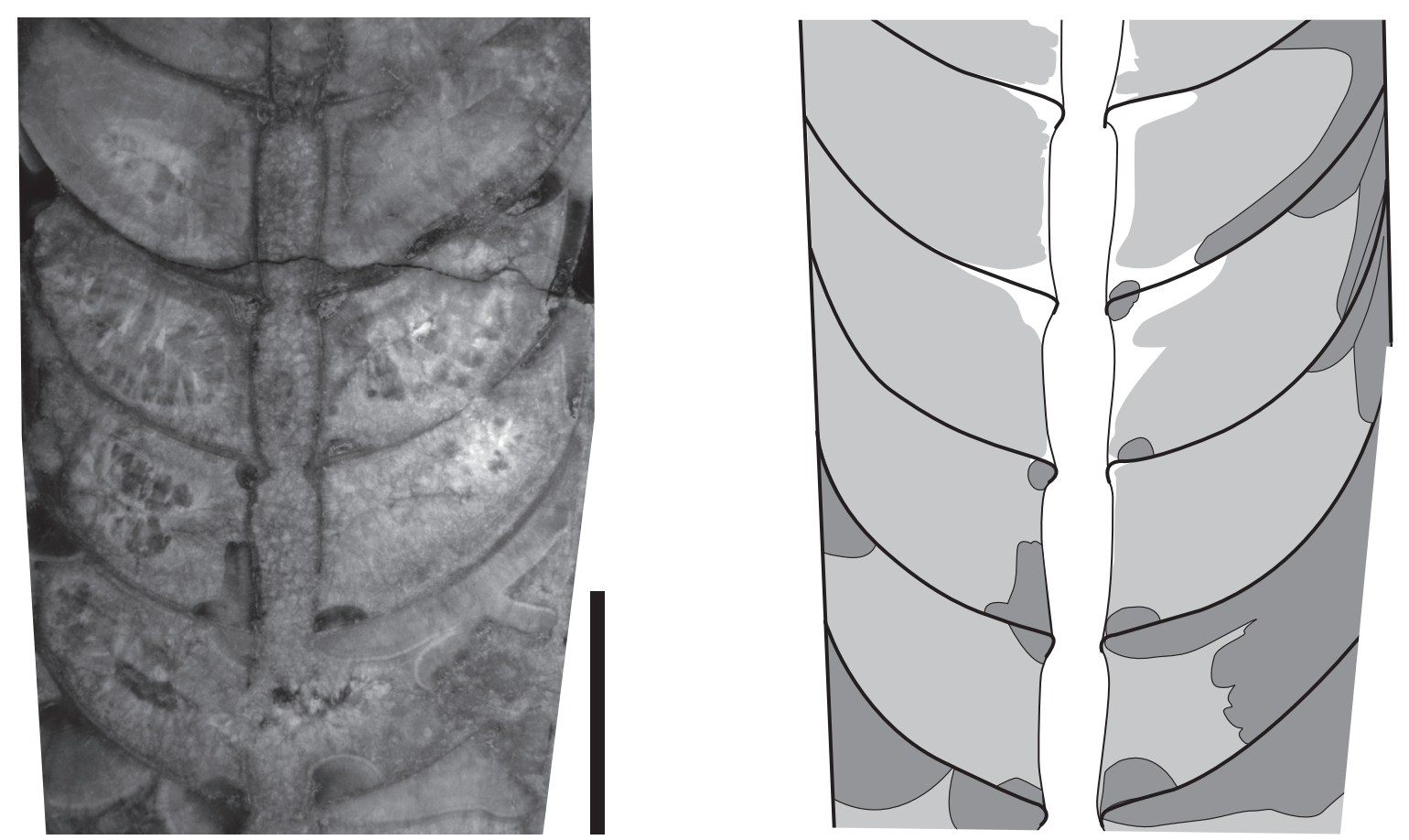

Fig. 24. Polished median section (left) and interpretation (right) of Pleurorthoceras osmundsbergense sp. nov., NRM-PZ Mo 190102c, Osmundsberget, Boda Limestone. Dark grey = episeptal and hyposeptal (primary?) deposits; light grey $=$ mural (secondary?) deposits. Scale bar $=10 \mathrm{~mm}$. 


\section{Other material examined}

An additional 43 non-type specimens from Osmundsberget are in the collections of the NRM.

\section{Description}

The holotype is a nearly complete specimen with a length of $280 \mathrm{~mm}$, with a diameter of $15-48 \mathrm{~mm}$ (angle of expansion $6.7^{\circ}$ ) and a very slightly curved conch (Figs 18E, 23A). The angle of expansion decreases with size to form a nearly tubular adult body chamber. The shell surface is nearly smooth, but fine, irregularly spaced, rounded striae run obliquely transverse, forming a shallow sinus on the concave side of the conch curvature.

In specimen NRM Mo 150102, which is a fragment of a juvenile phragmocone with a length of 105 $\mathrm{mm}$ and a diameter of $22-37 \mathrm{~mm}$ (angle of expansion $8.1^{\circ}$ ), the distance between septa is $0.24-0.36$ of the corresponding conch cross section. The siphuncle is nearly central in apical parts, becoming more eccentric at adoral parts (SPR 0.46). The siphuncular segments are barrel-shaped, slightly expanded within the chambers, with a maximum siphuncle diameter of $3 \mathrm{~mm}$ at septal foramen at a conch cross section diameter of $22 \mathrm{~mm}$ ( 0.14 of conch cross section). The septal necks are suborthochoanitic (Figs $13 \mathrm{G}, 14 \mathrm{C}$ ). No endiphuncular deposits occur, and remains of heavy mural cameral deposits are preserved in the apical parts of the fragment (Fig. 24).

\section{Comparison}

Pleurorthoceras osmundbergense sp. nov. differs from the genotype and the second North American species, P. selkirkense (Whiteaves, 1892) in having a significantly higher angle of expansion and a slightly curved growth axis. P. subcostatum (Portlock, 1843) from Killey Bridge Formation, latest Katian (Evans 1993), differs in having a distinct reticulate ornamentation.

\section{Stratigraphic and geographic range}

Boda Limestone, Siljan District, Sweden; late Katian, Ordovician.

Family Proteoceratidae Flower, 1962

Genus Gorbyoceras Shimizu \& Obata, 1935

\section{Type species}

Orthoceras gorbyi Miller in Miller \& Faber, 1894, probably from the Saluda Formation, latest Katian, Franklin County, Indiana, USA; by original designation.

\section{Diagnosis}

Slender, circular or slightly compressed orthocones with symmetrically curved septa and straight transverse sutures; sutures parallel to annulations in each groove of the annulations; annulations with fine transverse ornament or growth lines; annulations more distinctive in adult growth stages; distinctive irregularly spaced longitudinal ridges that may form nodes at the ridges of the annulations; siphuncle subcentral, expanded in early growth stages, with short cyrtochoanitic septal necks, nearly tubular in later growth stages, with suborthochoanitic septal necks; mural cameral deposits developed much farther anteriorly than endosiphuncular deposits. (Adopted from Sweet 1964c; Kröger \& Isakar 2006.)

\section{Remarks}

A large number of species of Gorbyoceras exist, which are in need of a revision. Potentially most of the Late Ordovician North American species of Spyroceras Hyatt, 1884 belong to Gorbyoceras, but their 
internal characters are not yet described. Additionally, often the ontogenetic variability in ornamentation is poorly known. Evans (1993) synonymized a number of Late Ordovician species with the aspect of Gorbyoceras from Ireland within G. gracile (Portlock, 1843) and suggested that the number and strength of the longitudinal lirae are ontogenetically highly variable. Among the material assigned within G. gracile by Evans (1993) and listed in Evans (his table 5), not a single specimen shows any similarity with the material from the Boda Limestone. The specimens described by Evans (1993) may represent different species, but none of them can by synonymized with the Boda species of Gorbyoceras or Dawsonoceras.

Gorbyoceras alternestriatum (Strand, 1934) comb. nov. Figs 16F, 17F

Spyroceras alternestriatum Strand, 1934: 19, pl. 3, figs 5, 6.

Gorbyoceras sp. - Dzik 1984: 122, text-fig. 48d, pl. 35, fig. 1.

\section{Emended diagnosis}

Gorbyoceras with slightly cyrtoconic adult body chamber, shell slightly compressed, relatively large adult size of more than $50 \mathrm{~mm}$ in conch height; slightly irregularly spaced, pronounced rounded annulations, approximately five to six in a length equal to conch diameter; approximately 30 regularly spaced longitudinal lirae around the entire circumference; in interspaces between primary lirae one or two less pronounced secondary lirae occur, approximately 12-15 fine transverse angular lirae between two successive ridges of annulations; sutures straight, nearly transverse, one suture at each groove of the annulations. Siphuncle eccentric in juvenile, subcentral in more adult growth stages, septal perforation approximately one tenth of the diameter of the shell.

\section{Type locality and horizon}

Stavnestangen, Ringerike District, Norway, Bønsnes Formation, latest Katian, Late Ordovician.

\section{Material examined}

Two specimens (PMU 26769, 26770), Kallholn; one specimen (PMU 26771), Unskarsheden, Siljan District, Sweden; Boda Limestone, Boda Core Member, late Katian, Ordovician.

\section{Description}

Specimen PMU 26771 is a nearly complete body chamber of a mature individual with a length of $90 \mathrm{~mm}$ and an adoral conch height of $51 \mathrm{~mm}$ and $47 \mathrm{~mm}$ at the apical end of the specimen (angle of expansion $2.5^{\circ}$ ) (Fig. 16F). The conch cross section is slightly compressed with ratio of the width to height of 0.91 . The conch is slightly curved with the siphuncle, eccentric (SPR 0.34) on the convex side of the conch curvature. The septal perforation is $3 \mathrm{~mm}$ wide ( 0.06 of conch height). The septum at the base of the body chamber is shallow, with a depth of $10 \mathrm{~mm}$ ( 0.21 of conch height). The shell is annulated with slightly irregularly spaced and irregularly elevated rounded elevations; ca. six occur in a length equal to conch diameter. Around the circumference ca. 32 regularly spaced, distinctly raised primary lirae occur. In the interspaces one slightly less pronounced longitudinal raised line occurs. Additionally the conch is ornamented with fine, angular transverse lirae, 12-15 occurring between two successive ridges of the annulations, generating a fine reticulate pattern (Fig. 17F).

The two other specimens consist of portions of phragmocone with diameters from 18 to $22 \mathrm{~mm}$, and from 22 to $23 \mathrm{~mm}$ respectively, with angles of expansion of ca. $8^{\circ}$. The distance between two successive 
annuli is ca. 0.18 of the corresponding conch cross section. The cross section is nearly circular. In specimen PMU 26769 the distance between the chambers is 0.18 , and the suture lies in the groove of the annulation. The surface of this specimen is ornamented with 32 and 28 primary lirae, respectively. Between the primary lirae, one or two less pronounced secondary lirae occur.

\section{Remarks}

The specimens described above are assigned to Gorbyoceras alternestriatum (Strand, 1934) comb. nov., because they agree in detail with the specimens described by Strand (1934) from the Bønsnes Formation of Norway. The new data, available from the adult body chamber PMU 26771, and additional data regarding the internal characters permit a more detailed species diagnosis and emendation.

\section{Comparison}

This species is very similar to G. textumaraneum (Roemer, 1861) comb. nov. Both species have relatively large (more than $40 \mathrm{~mm}$ in conch diameter), curved adult body chambers, combined with a relatively widely spaced reticulate ornamentation. G. alternestriatum comb. nov. differs from the latter mainly in having a primary and secondary longitudinal ornamentation.

G. tetreauense Wilson, 1961 from the late Katian, Ottawa Formation, Canada is similar with respect to the angle of expansion and general aspects of ornamentation, but differs in having a more curved, stronger expanding conch with less pronounced annulations.

\section{Stratigraphic and geographic range}

Bønsnes Formation, latest Katian, Stavnestangen, Ringerike District, Norway (Strand 1934); latest Katian, erratic boulder, Międzyzdroje, Poland (Dzik 1984); Boda Limestone, Boda Core Member, late Katian, Siljan District, Sweden.

\section{Gorbyoceras sp. A \\ Figs 16C, 17C}

\section{Material examined}

Specimen PMU 26772 from Osmundsberget, Siljan District, Sweden; Boda Limestone, Boda Core Member, late Katian.

\section{Description}

A fragment of a conch ca. $22 \mathrm{~mm}$ long, with a diameter increasing from 22 to $25 \mathrm{~mm}$ (angle of expansion ca. $6^{\circ}$ ). No internal structures are preserved (Fig. 16C). The shell is strongly annulated and exhibits four annuli that show varying amplitudes (maximum amplitude of $1.5 \mathrm{~mm}$ ). About 16 pronounced primary lirae are present around the circumference; between each pair, three to four less pronounced, irregularly spaced secondary striae occur (Fig. 17C). About ten transverse lirae are present in a length equal to one cycle of annulation.

\section{Remarks}

This small annulated fragment with its 16 primary and more than 48 secondary longitudinal lirae is uniquely ornamented; no Ordovician orthocerid with a similar ornamentation is known. The ornamentation is most similar to species of Gorbyoceras and the specimen is interpreted as a new species of Gorbyoceras. However, this poorly preserved specimen does not provide sufficient data to justify the erection of a new species. 


\section{Gorbyoceras sp. B.}

Fig. 16D

\section{Material examined}

One specimen (PMU 26773), Kallholn, Siljan District, Sweden; Boda Limestone, Boda Core Member, late Katian.

\section{Description}

Specimen PMU 26773 is a diagenetically deformed and fragmented part of a body chamber and phragmocone $52 \mathrm{~mm}$ long and $43 \mathrm{~mm}$ in diameter (Fig. 16D). Apically a relatively deep septum is preserved (depth of curvature $8 \mathrm{~mm}, 0.19$ of conch height). The position and size of the siphuncle cannot be determined.

The shell is annulated, with distance between annuli of ca. $11 \mathrm{~mm}(0.26$ of conch cross section, ca. five annuli per distance equal to conch diameter). The shell is $2.1 \mathrm{~mm}$ thick at the culminations of the annuli, and $0.5 \mathrm{~mm}$ thick on the floors in between. As a consequence of the zones with thickened shell, the surface of the shell is strongly annulated with sharply rounded ridges, while the internal mould is only weakly annulated with much shallower ridges. The shell surface is ornamented with longitudinal lirae, but the preservation of the shell is too poor to conserve the details of the pattern of the ornamentation.

\section{Remarks}

This strongly annulated fragment displays a longitudinal ornamentation which is characteristic of Gorbyoceras. However, because details of the ornamentation, such as the number of primary and secondary lirae, are not preserved a species level determination is impossible. This specimen differs from known late Ordovician species of Baltoscandia in the exceptionally high amplitude of the annulations combined with the large diameter of the conch.

Genus Isorthoceras Flower, 1962

\section{Type species}

Orthoceras sociale Hall in Miller, 1877, from the Elgin Member, Maquoketa Formation, latest Katian, Graf, Iowa, USA; by original designation.

\section{Diagnosis}

Orthoconic longicones with subcircular cross section and subdued ornamentation, smooth or with fine transverse and/or longitudinal lirae. Siphuncle subcentral, with barrel-shaped early segments and subcylindrical later segments. Septal necks suborthochoanitic-cyrtochoanitic. Endosiphuncular annuli grow forward and backward, joining those of adjacentsegments to form continuous parietal lining ofuniform thickness throughout segments. Mural to episeptal cameral deposits. (Adopted from Flower 1962 and Frey 1995.)

$$
\begin{aligned}
& \text { Isorthoceras angelini sp. nov. } \\
& \text { urn:1sid:zoobank.org:act:D60B4D34-B324-4F4B-817D-2EBE1F0F09BA }
\end{aligned}
$$

Figs 13D, 14D, 17H, 23G, 25

\section{Diagnosis}

Isorthoceras with weakly curved conch with circular or slightly compressed cross section; angle of expansion decreases with conch size, ca. $7-9^{\circ}$ in premature growth stages; ornamented with fine longitudinal raised lirae and irregularly spaced transverse lirae; transverse lirae form shallow sinus on 
concave side of conch curvature; conch very weakly, irregularly undulated; mature size ca. $15 \mathrm{~mm}$; position of siphuncle subcentral in early growth stages and eccentric at convex side of conch curvature in late growth stages, septal necks are suborthochoanitic-cyrtochoanitic.

\section{Etymology}

In honour of Nils Peter Angelin (1805-1876), a Swedish geologist and paleontologist, for his pioneering work on the Swedish palaeozoic fossils (e.g., Angelin \& Lindström 1880).

\section{Type material}

\section{Holotype}

PMU 26774

\section{Paratypes}

Twelve paratypes: PMU 26775-26786, Kallholn, Dalarna, Boda Limestone, latest Katian.

\section{Type locality and horizon}

Kallholn, Siljan district, Dalarna, Sweden; Boda Limestone, Boda Core Member, late Katian, Ordovician.

\section{Description}

The holotype, PMU 26774, is a $40 \mathrm{~mm}$ long fragment of a phragmocone with a circular cross section and a diameter which is $5.8-9 \mathrm{~mm}$ of a length of $30 \mathrm{~mm}$ (angle of expansion 9.1) (Fig. 23G). The

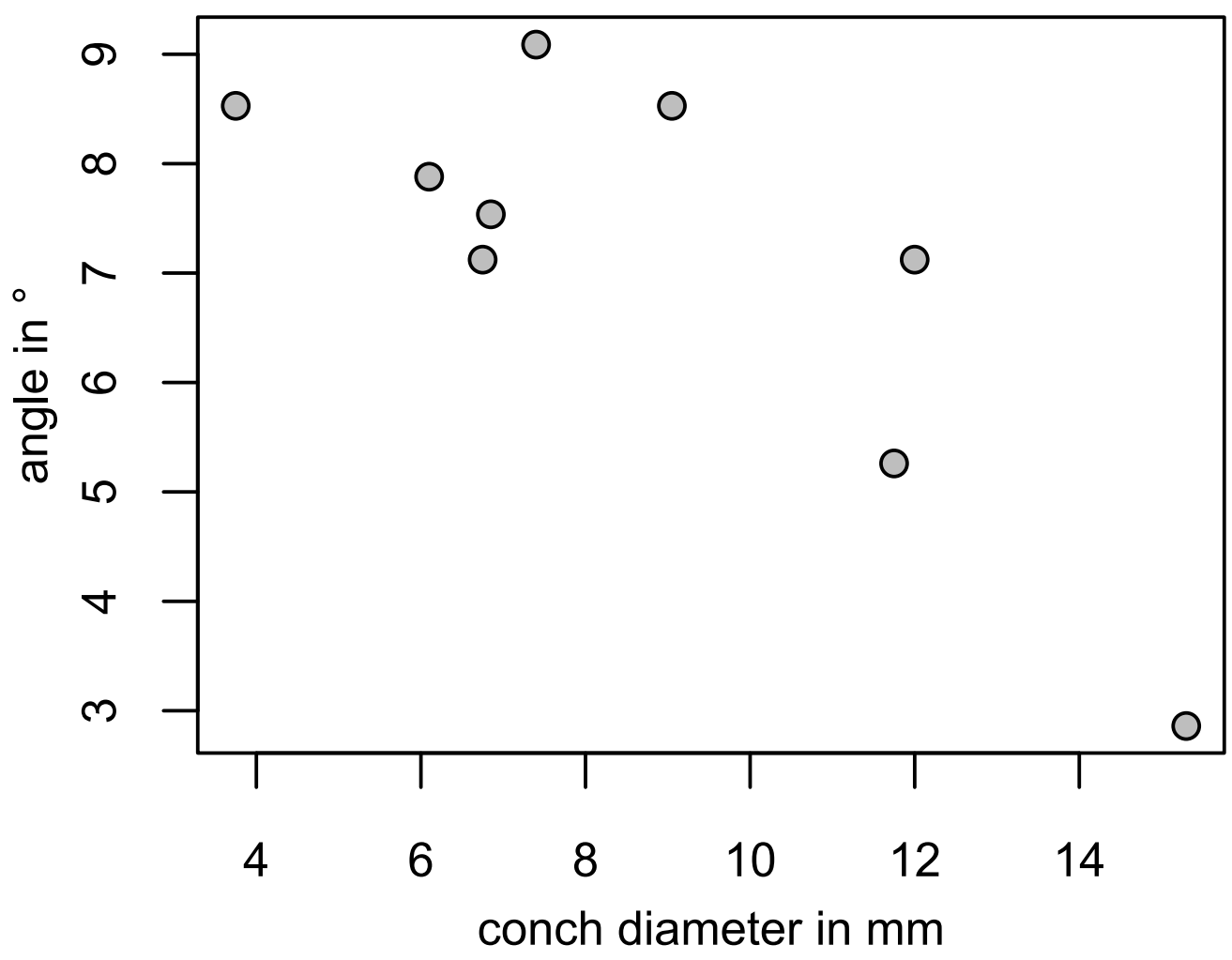

Fig. 25. Variability of the angle of expansion in fragments of different diameters of Isorthoceras angelini sp. nov. Note the tendency of decreasing angle of expansion with diameter. The adult diameter is reached at ca. $15 \mathrm{~mm}$. 
conch is ornamented with fine raised longitudinal lirae, which have a distance of ca. $0.2 \mathrm{~mm}$, and with transverse lirae, which have a distance of $0.1 \mathrm{~mm}$. The spacing of both the longitudinal and transverse lirae is slightly variable. Additionally, the surface of the shell undulates slightly, with a varying distance of ca. $2 \mathrm{~mm}$. The transverse ornamentation forms a very shallow sinus on the concave side of the conch curvature. The conch is very slightly curved with the siphuncle eccentric to subcentral in position. It shifts slightly to the convex side of the conch curvature during the growth of the organism. At the apical end of the fragment, the smallest distance of the siphuncle from the conch margin is $2.7 \mathrm{~mm}$ (SPR 0.46) and the chamber height is $3 \mathrm{~mm}$ (ca. 0.5 of corresponding conch height).

The details of the siphuncle and septal necks are seen in PMU 26784, a portion of phragmocone, increasing in diameter from ca. 6.8 to $8.7 \mathrm{~mm}$ (Figs 13D, 14C). At the adapical end of the specimen the siphuncle is $1.9 \mathrm{~mm}$ from the conch margin (SPR 0.28) and the distance between septa is $2.9 \mathrm{~mm}$ ( 0.43 of corresponding conch cross section). The siphuncle is nearly tubular, with very slightly inflated connecting rings. It has a diameter of 0.15 of the corresponding conch cross section. The septal necks are very short, poorly preserved, and appear to be suborthochoanitic or cyrtochoanitic. Episeptal and mural deposits occur (Figs 13D).

The nine available measurements of angles of expansion reveal a clear tendency of decreasing angle of expansion with increasing conch size. The maximum values are reached by the fragment of the lectotype, the average is $7.1^{\circ}$ and the smallest measurements are on the specimen with a maximum diameter of $15 \mathrm{~mm}$ (PMU 26786, Fig. 25).

PMU 26785 and 26786 are the largest fragments, both consisting of parts of body chambers that are nearly tubular. The ornamentation of these fragments is characterized by longitudinal and transverse lirae and a very shallow, irregular undulation. Pronounced, irregularly spaced growth lines also occur.

\section{Comparison}

This species of Isorthoceras is unique because of its combination of a relatively small adult size of only $15 \mathrm{~mm}$, its angle of expansion of $7-9^{\circ}$ and its eccentrically positioned siphuncle.

A very similar, yet undescribed species occurs in the Kullsberg Limestone, early-mid Katian of Dalarna, Sweden. This species differs from I. angelini sp. nov. in having a more pronounced transverse ornamentation.

A reticulate ornamentation occurs also in Orthoceras lepteanarum Angelin in Angelin \& Lindström, 1880 , a species which is known from a single specimen (NRM Mo 152344) from the Boda Limestone of Ostbjörka. This specimen is a poorly preserved small fragment of a phragmocone with a diameter of $38 \mathrm{~mm}$. It is very likely to represent a species of Isorthoceras and may be closely related or conspecific with Isorthoceras tenuitextum (Hall, 1847). The ornamentation in NRM Mo 152344 is partly preserved and consists of elevated, irregularly spaced, longitudinal and transverse lirae. The distance between the longitudinal striae (ca. $1.5 \mathrm{~mm}$ ) is considerably larger than that of the transverse elements, resulting in a surface pattern of minute transverse rectangles. Compared with I. angelini sp. nov., the longitudinal striae are significantly more widely spaced, both in absolute dimensions (more than $1 \mathrm{~mm}$ in O. lepteanarum against ca. $0.1-0.2 \mathrm{~mm}$ in I. angelini sp. nov.) and in relative dimensions (more than 5 transverse lirae occur per distance similar to the distance of two longitudinal striae in I. (?) lepteanarum comb. nov. against ca. 1.5-2 in I. angelini sp. nov.).

Isorthoceras tenuitextum (Hall, 1847), which is common in late Katian sediments of Eastern Laurentia, is similar in ornamentation, but differs in having an adult size of more than $25 \mathrm{~mm}$ and a less, but more consistently expanding conch with an angle of expansion of ca. $6^{\circ}$. 
Isorthoceras albersi (Miller \& Faber, 1894), which is the most common species within the Lexington Limestone, Kentucky, USA (see Frey 1995: 60), has a similar ornamentation and angle of expansion, but differs in having a larger adult size.

\section{Stratigraphic and geographic range}

Boda Limestone, late Katian, Dalarna, Sweden.

Isorthoceras curvilineatum sp. nov. urn:1sid:zoobank.org:act:7B1F09EA-8B80-44EC-8F80-7E0EDD3F4E3D

Figs $17 \mathrm{G}, 23 \mathrm{~F}$

\section{Diagnosis}

Transversally ornamented, straight Isorthoceras with circular cross section and low angle of expansion of less than $2^{\circ}$. Ornamented with ca. ten rounded transverse striae per millimetre, which form characteristic shallow hyponomic sinus with two directly adjacent shallow salients. Adult size clearly less than ca. 10 $\mathrm{mm}$ in cross section. Siphuncle central with diameter ca. 0.1 of conch cross section.

\section{Etymology}

Refers to the conspicuously curved transverse ornamentation of this species.

\section{Type material}

\section{Holotype}

PMU 26787.

\section{Paratypes}

Two paratypes: PMU 26788 and 26789, Osmundsberget, Siljan District, Sweden; Boda Limestone, Boda Core Member, late Katian, Ordovician.

\section{Type locality and horizon}

Osmundsberget, Siljan District, Sweden, Boda Limestone, Boda Core Member, late Katian, Ordovician.

\section{Description}

Three specimen from Osmundsberget (PMU 26787-26789) are very similar to each other, with a very low angle of expansion of less than $2^{\circ}$, conch diameters between 6 and $8 \mathrm{~mm}$ and a very fine transverse ornamentation, with ca. ten rounded striae per millimetre (Fig. 17G). The striae are laterally slightly oblique, and form a shallow hyponomic sinus with two directly adjacent shallow projections on the left and right side.

The holotype is a fragment of parts of a phragmocone and body chamber with a length of $35 \mathrm{~mm}$ and a diameter of 6.2-7.2 $\mathrm{mm}$ (angle of expansion 1.6 $6^{\circ}$ (Fig. 23F). The siphuncle is central, with a diameter of the septal perforation of $0.6 \mathrm{~mm}$ at the apical end of the fragment. The length of the body chamber cannot be measured, because no traces of septa are visible in the middle parts of the holotype.

\section{Remarks}

A very small adult size of less than $10 \mathrm{~mm}$ is assumed for this species, based on the very low angle of expansion, which is only $0.7^{\circ}$ in the largest specimen, with a maximum diameter of $7.5 \mathrm{~mm}$.

This species is assigned within Isorthoceras because the general conch shape is very similar to other small species of Isorthoceras, such I. angelini sp. nov. However, some uncertainty remains in the generic assignment, because the internal characters are not known. A similar narrow, transverse ornamentation 
is known from Isorthoceras elongatocinctum (Portlock, 1843) comb. nov., which differs in having a directly transverse striation.

\section{Stratigraphic and geographic range}

Boda Limestone, late Katian, Dalarna, Sweden.

Isorthoceras dalecarlense Kröger et al., 2011

Figs 4B, 26

Isorthoceras dalecarlense Kröger et al., 2011: 45, fig. 9c, g.

\section{Diagnosis}

Smooth, nearly straight Isorthoceras with circular cross section and comparatively low angle of expansion of $6^{\circ}$, chamber distance 0.3 of corresponding cross section, depth of septal curvature ca. 0.26 of corresponding cross section. Adult size $>35 \mathrm{~mm}$ in cross section. Siphuncle eccentric in early, subcentral

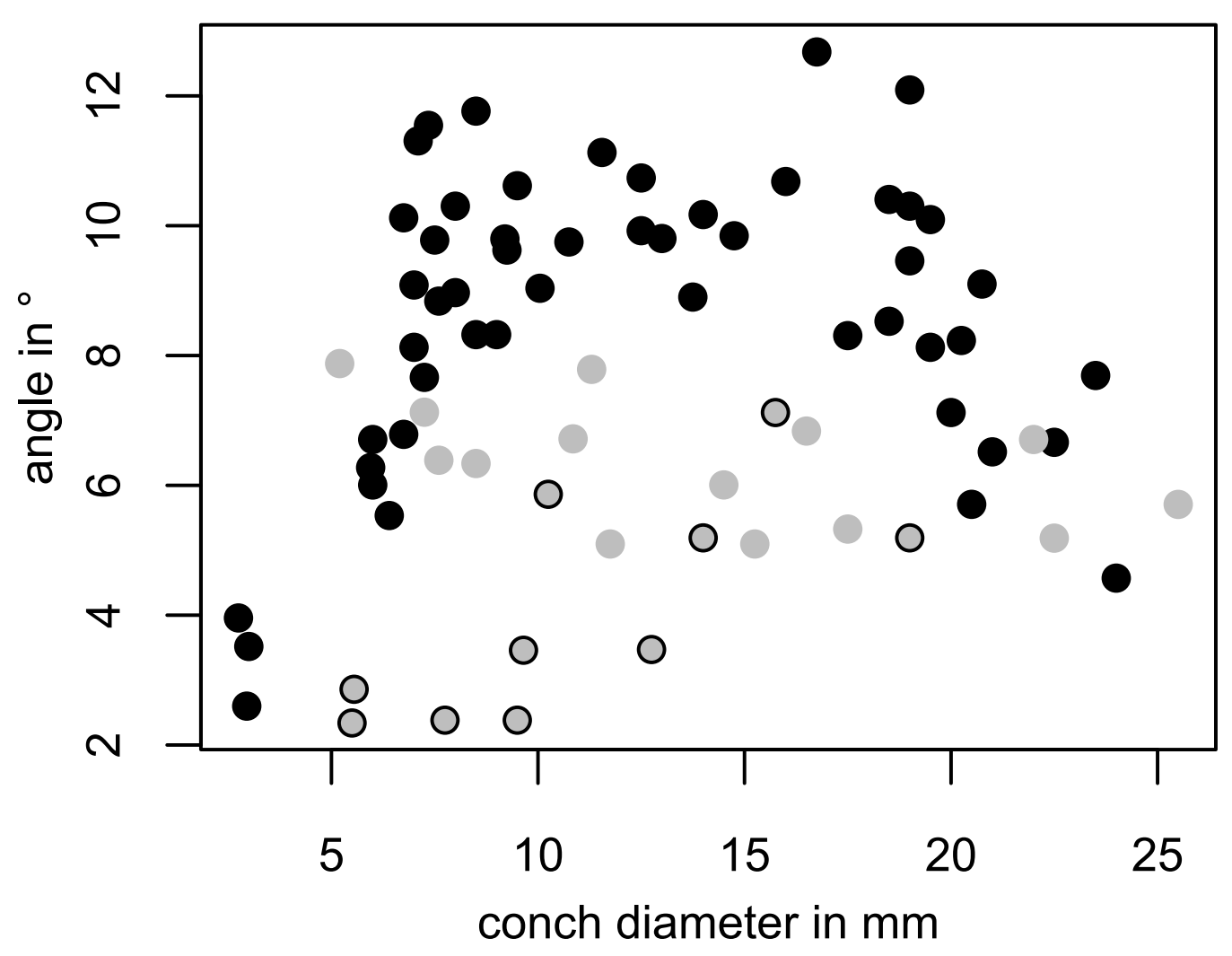

Fig. 26. Variability of the angle of expansion in fragments of different diameters of Isorthoceras wahlenbergi Niko, 2008 (black points) and Isorthoceras dalecarlense Kröger et al., 2010 (grey points). The black circles refer to specimens figured in Kröger et al. (2011: fig. 11) and identified as I. dalecarlense, therein. The complete dataset, presented herein, demonstrates that a definite species distinction by angle of expansion and size alone is impossible in fragmentary specimens with angles of expansion between $6^{\circ}$ and $8^{\circ}$. Additionally, the complete dataset reveals that specimens with conch diameter $>7 \mathrm{~mm}$ and angle of expansion $>8^{\circ}$ in Kröger et al. (2011: fig. 11) must correctly be interpreted as fragments of I. wahlenbergi. 
in later growth stages, siphuncular segments slightly expanded within chambers with diameter ca. 0.1 of conch cross section. Septal necks short, on border-line between cyrtochoanitic and suborthochoanitic. In apical parts of siphuncle thin parietal deposits that ventrally fuse to irregular endosiphuncular lining at extreme apical part of conch. Cameral deposits not known.

\section{Type locality and horizon}

Osmundsberget quarry, Rättvik Municipality, Siljan District, Sweden (locality Osmundsberget 1 of Ebbestad \& Högström 2007); nautiloid bed, top of Glisstjärn Formation, Hirnantian, Late Ordovician.

\section{Material examined}

Nineteen specimens (PMU 26790-26808) from Kallholn, Siljan District, Sweden; Boda Limestone, latest Katian, Ordovician.

\section{Comparison}

The species was described in detail by Kröger et al. (2011). Here, details of the variability of the external conch features can be added. Fourteen specimens are assigned to this species. They are similar in all aspects to I. wahlenbergi Niko, 2008, but differ from the type of I. wahlenbergi in having a significantly lower angle of expansion.

The angle of expansion varies strongly within the smooth Boda Limestone specimen of Isorthoceras (Fig. 26). A slender form (I. dalecarlense) and a wide angled variety (I. wahlenbergi) can be distinguished (compare Fig. 4B, and 4C). But the distinction is complicated by the ontogenetic change of angle of expansion in both varieties. In both varieties the angle of expansion is initially low, reaches maximum values in premature growth stages and declines in fragments of the mature body chamber.

Nevertheless, in the conch size/angle of expansion-plot (Fig. 26) two groups can be distinguished in each individual growth section, but not in juveniles and mature specimens. This overlapping in the plot is an effect of the method of measurement, which does not distinguish between long and short fragments (the angle of expansion is measured in fragments with different lengths). Thus, in smaller fragments of juvenile and mature conchs a distinction between the two species is impossible, but longer conch fragments will always reveal a strong difference in intermediate growth stages.

As a result of these measurements it is clear that some of the specimens measured by Kröger et al. (2011: fig. 10) represent I. wahlenbergi. Consequently, I. wahlenbergi also occurs within the Hirnantian Glisstjärn Formation (see Fig. 26).

Balashov (1975) described smooth, slender orthocerids from the Molodov Horizon of Podolia as Michelinoceras dnestrovense. The shape of the septal necks and the siphuncular segments, as well as the chamber spacing indicate that these specimens are better assigned to Isorthoceras. The chamber spacing of the figured specimen of $I$. dnestrovense (Balashov, 1975) comb. nov. varies from 0.17 to 0.2 and thus is considerably narrower than in I. dalecarlense.

\section{Stratigraphic and geographic range}

Boda Limestone, Glisstjärn Formation, late Katian-Hirnantian, Dalarna, Sweden (see discussion of I. dalecarlense, above).

Isorthoceras cf. elongatocinctum (Portlock, 1843) comb. nov. Figs 17A, D, 23D-E, 27

Orthoceras elongato-cinctum Portlock, 1843: 372, pl. 27, fig. 2a-b. 
Orthoceras elongato cinctum - Baily 1875: pl. 12, fig. 10 (non pl. 13, fig. 8; see discussion below).

Orthoceras elongatocinctum - Blake 1882: 119, pl. 13, figs 7, 8, 8a. - Evans 1996: 118, pl. 21, figs 1, 2, text-fig. 21f.

Geisonocerina elongatocinctum - Holland 1993: 39, text-fig. 1g, i; 2000: 181, text-fig. $1 \mathrm{~m}$.

Orthoceras aff. elongatocinctum - Evans 2002: 81, pl. 1, figs 1-3.

\section{Diagnosis}

Transversally ornamented, straight Isorthoceras with circular cross section and comparatively low angle of expansion of ca. $4^{\circ}$, chamber distance $0.3-0.4$ of corresponding diameter; transverse ornamentation consists of distinctly elevated, sharp, sometimes imbricate lirae, with distance of ca. six to ten per millimetre; siphuncle nearly central with diameter ca. 0.1 of corresponding conch diameter. (Adopted from Holland 1993; Evans 1993.)

\section{Type locality and horizon}

Killey Bridge Formation, County Tyrone, Northern Ireland. Katian Stage.

\section{Material examined}

Twenty-two specimens, one (PMU 26809) from Osmundsberget; 20 from Kallholn, Siljan district, Sweden (PMU 26810-26829); all Boda Limestone, Boda Core Member, late Katian, Late Ordovician. One additional specimen (PMU 26830) from mid Katian Kullsberg Limestone, Kullsberg, Siljan district, Sweden.

\section{Description}

Specimen PMU 26825 is a portion of the phragmocone and a nearly complete mature body chamber, with a diameter increasing from 8 to $13 \mathrm{~mm}$ and a length of $75 \mathrm{~mm}$ (angle of expansion $3.8^{\circ}$ ). It is ornamented

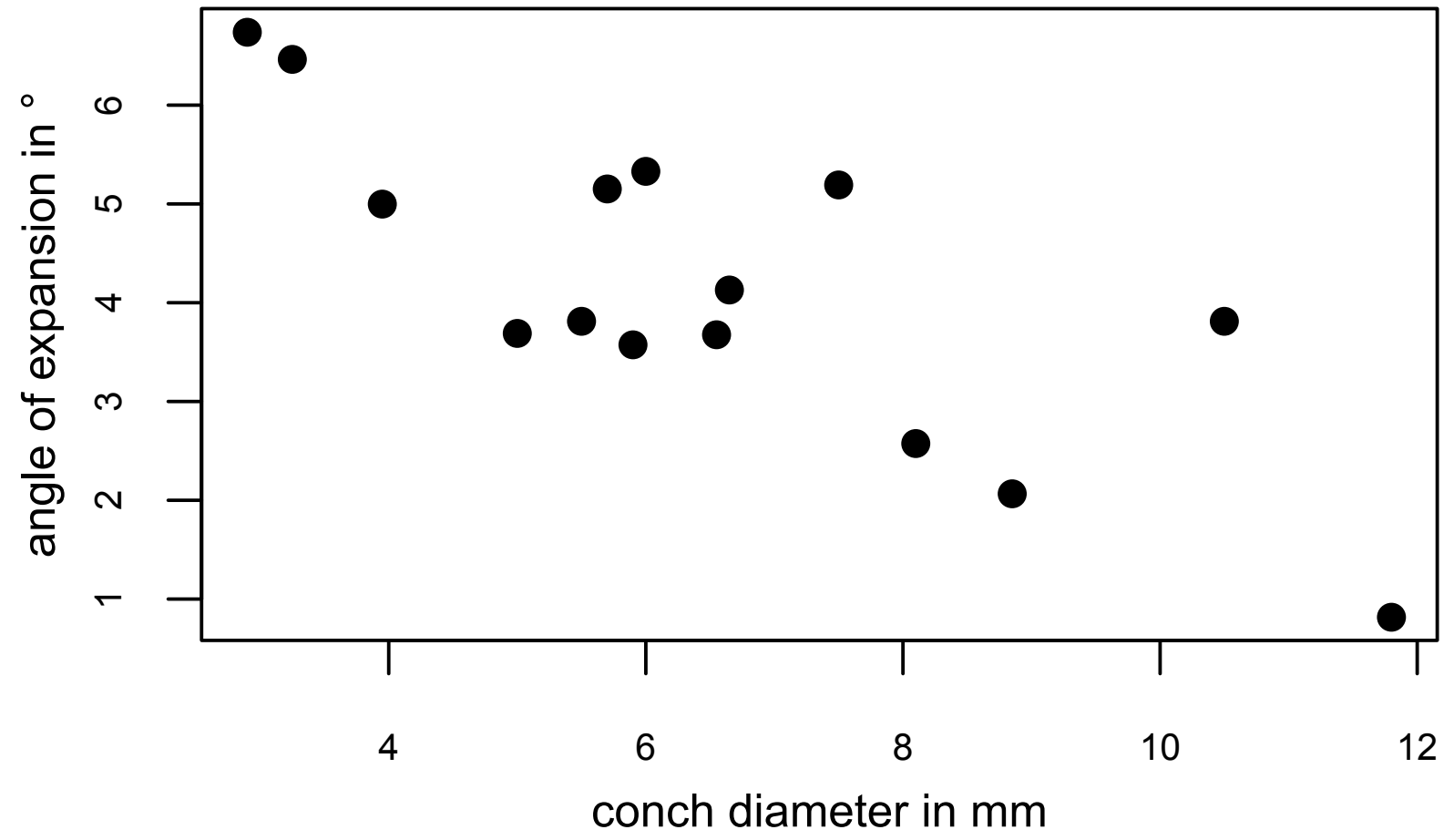

Fig. 27. Angle of expansion of 15 measured specimen of Isorthoceras cf. elongatocinctum (Portlock, 1843), Boda Limestone, Late Katian, Dalarna, Sweden. 
with sharp, distinctly raised lirae; apically with ca. four to five lirae per millimetre. Adorally the lirae are increasingly more crowded and irregularly spaced, with ca. ten per millimetre near the aperture. The lirae are slightly oblique and form a distinct, but shallow hyponomic sinus on the antisiphuncular side of the conch. An apertural shell thickening and the low apical angle indicate maturity.

When comparing the seventeen measured specimens, a clear trend of decreasing angle of expansion becomes apparent (Fig. 27). In early growth stages the angle is as high as $7^{\circ}$, but it continuously decreases with increasing conch diameter. The position of the siphuncle is preserved in specimens PMU 26814-26815 (SPR 0.49, 0.46), 26810 (SPR 0.4), 26823 (SPR 0.43) and 26826 (SPR 0.44). In smaller specimens the siphuncle is more eccentric, but in all other specimens it is nearly centrally positioned. The septal spacing varies between 0.3 (PMU 26815) and 0.44 (PMU 26826) of the corresponding conch height.

\section{Remarks}

This species was previously known only from the latest Katian sediments of Northern Ireland and Wales. Details of the internal characters were described by Evans (1993: fig. 8), who revised the species based on more than one hundred specimens. Evans (1993: 167) described the septal necks as orthoconic, but his fig. 8 shows septal necks which must be termed "suborthochoanitic" in the strict sense (see Material and Methods, above). The shape of the septal necks, the constricted siphuncle, the general conch shape and the ornamentation are similar to other species of Isorthoceras. Based on this similarity, this species is here assigned to Isorthoceras.

The largest specimen in the Irish material has a diameter of $25 \mathrm{~mm}$. The specimens from the Boda Limestone and the diagram in Evans (1993: fig. 9) suggest a maximum size of less than $15 \mathrm{~mm}$, which is the reason why the Boda specimens are assigned with the addendum "cf." to this species.

These specimens are identical in external characters to the specimens described by Evans (1993). Additional information on the variability of the apical angle and the ornamentation are provided by the specimens from the Boda Limestone. Specimen PMU 26825 is the most completely preserved fragment and demonstrates the ontogenetic variation of the transverse ornamentation and angle of expansion (Figs $17 \mathrm{~A}, \mathrm{D} ; 23 \mathrm{D}-\mathrm{E})$. The angle of expansion of mature parts of the shell is very small, and the spacing of the transverse lirae is narrower and more irregular in later growth stages.

\section{Comparison}

This species differs from other species of Isorthoceras in having an ornamentation of fine, but distinctly elevated, acute transverse lirae, ca. 0.2 to $0.1 \mathrm{~mm}$ distant.

Geisonoceras heintzi Strand, 1934, from the Sørbakken formation in the Ringerike Distict, Norway, probably represents a species of Isorthoceras and is a small, slender transversally ornamented form that differs from I. elongatocinctum comb. nov. in having transverse lirae which are more distantly spaced (distance ca. $0.4 \mathrm{~mm}$ ). Isorthoceras heroyense (Strand, 1934) comb. nov. is similar an ornamentation, but differs in having a more eccentric siphuncle (SPR 0.31) and a larger angle of expansion $\left(5-9^{\circ}\right)$.

\section{Stratigraphic and geographic range}

Kildare Limestone, Killey Bridge Formation, Portrane Limestone, late Katian, Ireland, Keisley Limestone, late Katian, Cumbria, UK (Holland 1993; Evans 1996, 2002); Sholeshook Limestone, late Katian, South Wales, UK (Evans 1996); lower Wether Law Linn Formation, Telychian, Ireland (Holland 2002); Boda Limestone, late Katian, Siljan District, Sweden. 
Isorthoceras heroyense (Strand, 1934) comb. nov.

Figs 23I, 28A

Geisonoceras herøyense Strand, 1934: 15, pl. 3; fig. 16.

\section{Diagnosis}

Transversally ornamented, straight Isorthoceras with circular cross section and comparatively low angle of expansion of ca. $5^{\circ}$, chamber distance 0.5 of corresponding cross section; transverse ornamentation consists of rounded, sharp, raised lirae, with distance of ca. six per millimetre; siphuncle eccentric with diameter ca. 0.13 of conch cross section. (Adopted from Strand 1934.)
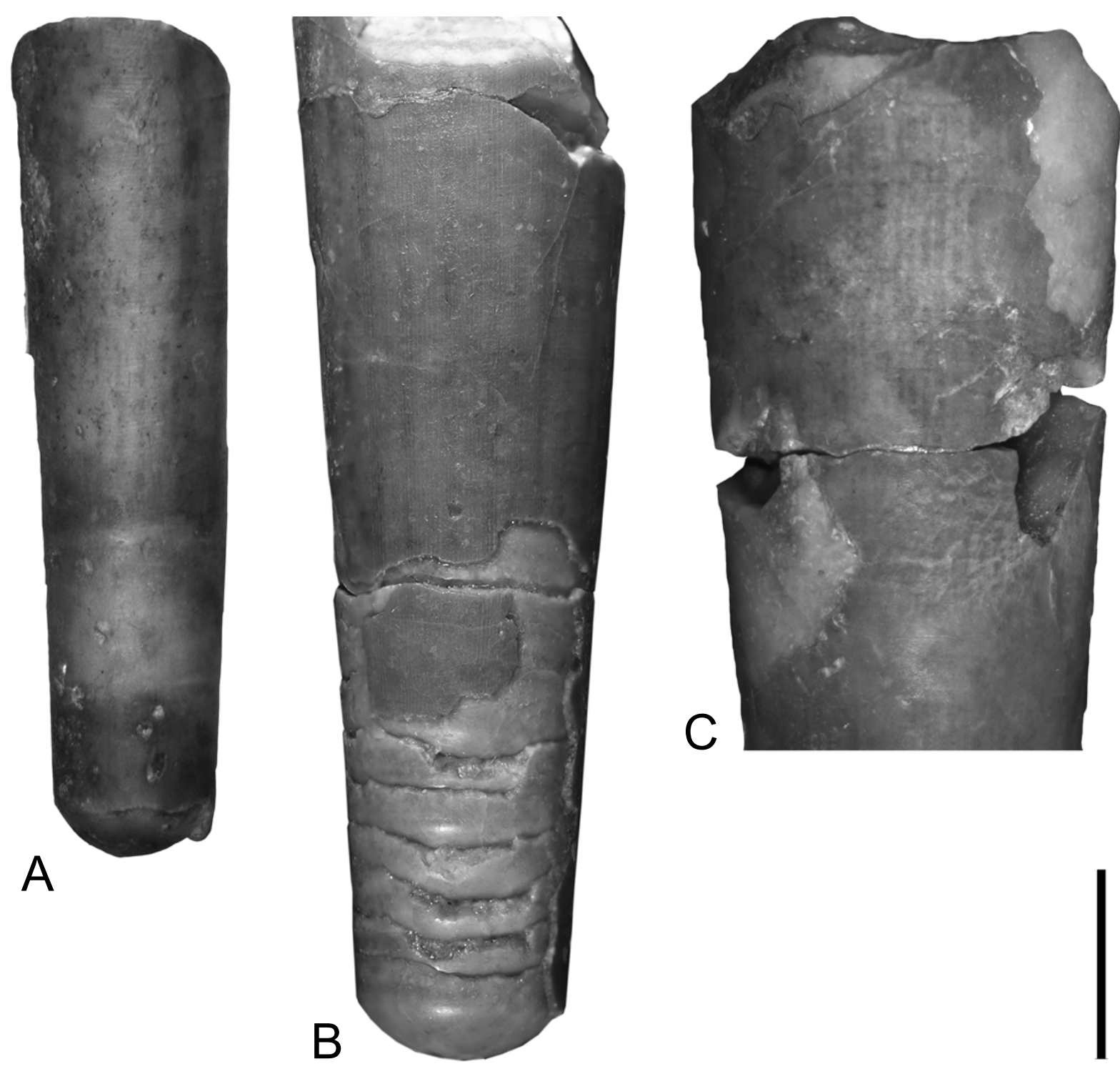

Fig. 28. Color marks in Isorthoceras Flower, 1962, Boda Limestone. Longitudinal striae of varying width occur in several specimen of Isorthoceras; see text for discussion. A. Isorthoceras heroyense (Strand, 1934) comb. nov., PMU 26831, Kallholn. B. Isorthoceras suave (Angelin in Angelin \& Lindström, 1880) comb. nov., PMU 26835, Osmundsberget. C. Isorthoceras wahlenbergi Niko, 2008, PMU 26862, Kallholn. Scale bar $=10 \mathrm{~mm}$ for all figures. 


\section{Type locality and horizon}

Herøya near Porsgrunn, Norway; Herøya Formation ("Gastropod Limestone"), late Katian, Late Ordovician.

\section{Material}

Two specimens (PMU 26831, 26832) from Kallholn, Siljan District, Sweden; Boda Limestone, Boda Core Member, late Katian, Ordovician.

\section{Description}

Specimen PMU 26831 is a fragment of a body chamber with a length of $35 \mathrm{~mm}$ and a diameter of 9.2-12 $\mathrm{mm}$ (angle of expansion $4.5^{\circ}$ ) (Figs 23I, 28A). The basal septum of the body chamber is preserved, with a convexity of ca. $3 \mathrm{~mm}$ and a septal perforation with a diameter of $1.5 \mathrm{~mm}$ ( 0.16 of conch cross section). The siphuncle is positioned $2.3 \mathrm{~mm}$ from the conch margin (SPR 0.25). The conch is ornamented with fine transverse lirae, ca. six in a distance of one millimetre, which are slightly oblique, projecting adorally on the prosiphuncular side of the conch and forming shallow and wide sinus on the antisiphuncular side. Around the circumference several brown bands are preserved (Fig. 28A). The bands are ca. $0.5 \mathrm{~mm}$ wide; a number of 28 would occur around the total circumference.

\section{Remarks}

This species is assigned to Isorthoceras on the basis of the general similarity of the external conch characters to those of other species of this genus. Nothing is known about the adult size of this species, but the decreased angle of expansion of the two specimens from the Boda Limestone suggest an adult size of no more than $15 \mathrm{~mm}$.

\section{Comparison}

This species is most similar to I. junceum (Hall, 1847) with respect to the transverse ornamentation, but differs in having more widely spaced transverse striae (six per millimetre in I. heroyense comb. nov.; ten per millimetre in I. junceum) and a higher angle of expansion at similar conch diameters. The strongly eccentric siphuncle is unique amongst known species of Isorthoceras.

\section{Stratigraphic and geographic range}

Herøya near Porsgrunn, Norway, Herøya Formation ("Gastropod Limestone"), Frognøya Island, Ringerike, Norway, Bønsnes Formation (Strand 1934); Boda Limestone, Siljan District, Sweden; all late Katian, Late Ordovician.

Isorthoceras junceum (Hall, 1847)

Figs 17E, 23C

Orthoceras junceum Hall, 1847: 204, pl. 47; fig. 3a-f.

Geisonoceras junceum - Balashov 1956: 199, pl. 4, fig. 4a-b.

Isorthoceras? junceum - Kröger et al. 2011: 46, figs 4a, 9h-i (with synonymy).

\section{Diagnosis}

Transversally ornamented, straight Isorthoceras with circular cross section and comparatively low angle of expansion of $5^{\circ}$, chamber distance $0.2-0.3$ of corresponding cross section; adult size ca. $10-11 \mathrm{~mm}$ in cross section; siphuncle subcentral-central with diameter ca. 0.1 of corresponding conch cross section. (Compiled from Hall 1847.) 


\section{Type locality and horizon}

Watertown, New York, USA; Trenton Formation, early Katian, Late Ordovician.

\section{Material}

Two specimens (PMU 26833, 26834) from Kallholn, Siljan District, Sweden; Boda Limestone, late Katian, Ordovician.

\section{Description}

Specimen PMU 26833 is a fragment of a body chamber $40 \mathrm{~mm}$ long, with a diameter increasing from 11 to $12.8 \mathrm{~mm}$ (angle of expansion $2.6^{\circ}$ ). At the adoral end of the specimen, the cast possesses a ca. 3 mm wide apertural constriction, which indicates a mature apertural shell thickening. The shell surface is ornamented with ca. ten fine rounded transverse striae per millimetre.

The second specimen is a $44 \mathrm{~mm}$ long portion of a phragmocone, with a diameter increasing from 6.2 to $8.8 \mathrm{~mm}$ (angle of expansion $3.4^{\circ}$ ) and a central thin siphuncle (Figs 17E, 23C).

\section{Remarks}

The two specimens are assigned to I. junceum based on the general similarity of the conch dimensions, the low angle of expansion, and the characteristic narrow transverse ornamentation. The adult conch diameter of specimen PMU 26833 is slightly larger than in other specimens of this species, which is interpreted as intraspecific variation.

The species was discussed in detail by Kröger et al. (2011). Herein the question mark that was positioned after the genus name by Kröger et al. (2011) is omitted, because a comparison of known species of Isorthoceras clearly indicates that this genus is characterized by the typical conch features that are listed above. The internal characters of the type of this species are still not known, but the external features are so similar to those of other species of the genus, that it justifies assigning O. junceum to Isorthoceras.

\section{Comparison}

Isorthoceras romingeri (Foerste, 1932) is a finely transversely striated Isorthoceras from the Black River Formation of Minnesota, USA, which differs in having a larger adult size (more than $17 \mathrm{~mm}$ in cross section) and a narrower chamber spacing (seven chambers occur per distance similar to corresponding cross section).

\section{Stratigraphic and geographic range}

Trenton Limestone, early Katian, from New York, USA (Hall 1847); Rocklandian-Edenian, mid Katian, from north central USA (Catalani 1987); Martinsburg Shale, late Katian (Bassler 1919); Utica Shale, late Katian (Flower 1946); Anderskyi bed, southern Kazakhstan, late Katian (Balashov 1956); Boda Limestone, late Katian-Glisstjärn Formation, Hirnantian, Siljan District, Sweden.

Isorthoceras suave (Angelin in Angelin \& Lindström, 1880) comb. nov.

Figs 17I, 23B, 28B

Orthoceras suave Angelin in Angelin \& Lindström, 1880: 3, pl. 7, figs 13-17.

\section{Diagnosis}

Isorthoceras with weakly curved conch and circular or slightly compressed cross section; angle of expansion ca. $9^{\circ}$ in premature growth stages; ornamented with fine longitudinal raised lirae and faint 
transverse irregularly spaced growth lines; mature size more than $20 \mathrm{~mm}$; siphuncle eccentric to subcentral at convex side of conch curvature.

\section{Type material}

\section{Lectotype}

NRM-Mo 151187 (Angelin \& Lindström 1880: pl. 7, figs 16-17) (designated herein).

Paralectotype

NRM-Mo 151186 (Angelin \& Lindström 1880: pl. 7, fig. 14).

\section{Type locality and horizon}

Ostbjörka, Siljan district, Dalarna, Sweden; Boda Limestone, Boda Core Member, late Katian, Ordovician.

\section{Other material examined}

Eight specimens: three specimens (PMU 26835-26837), Osmundberget, Dalarna; four specimens (PMU 26838- 26841), Kallholn, Dalarna; all from the Boda Limestone, Boda Core Member, late Katian.

\section{Decription}

The lectotype is a fragment of a very slightly curved phragmocone, $42 \mathrm{~mm}$ long, with a diameter that increases from 8 to $14 \mathrm{~mm}$ (angle of expansion $8.1^{\circ}$ ). It is ornamented with fine longitudinal raised striae.

Specimen PMU 26835 is a nearly straight portion of phragmocone $43 \mathrm{~mm}$ long, increasing in diameter from 10 to $17 \mathrm{~mm}$ (angle of expansion $9.2^{\circ}$ ) (Fig. 23B) and a circular conch cross section. The siphuncle is nearly central, $5.5 \mathrm{~mm}$ from the conch margin at a corresponding conch diameter of $12.5 \mathrm{~mm}$ (SPR $0.44)$. The chamber height is $3 \mathrm{~mm}$ at a diameter of 14.5 ( 0.21 of conch diameter). The diameter of the septal perforation is $1 \mathrm{~mm}$ at a conch diameter of $12.5 \mathrm{~mm}$ ( 0.08 of conch diameter). The specimen is ornamented with fine raised lirae, ca. five per millimeter, and very faint, irregularly spaced growth lines ca. $1 \mathrm{~mm}$ apart (Fig. 17I). Approximately $34 \mathrm{ca} .0 .7 \mathrm{~mm}$ wide dark bands run longitudinally around the entire circumference (Fig. 28B).

In another specimen (PMU 26836) the siphuncle is more eccentrically positioned. At a conch diameter of $21 \mathrm{~mm}$, the siphuncle is positioned $8 \mathrm{~mm}$ from conch margin (SPR 0.38).

The angle of expansion of the six available specimens varies between 5.7 and $9.9^{\circ}$, with no size trend. The chamber height varies between 0.2 and 0.3 of the corresponding conch height.

\section{Remarks}

The adult size of this species must be clearly more than $20 \mathrm{~mm}$. The largest specimen (PMU 26836) in the collection is a fragment of a phragmocone with a diameter of $21 \mathrm{~mm}$ and the septal spacing shows no signs of septal crowding. The longitudinal ornamentation is crossed only by faint, irregularly spaced growth lines. A total of 34 longitudinal color bands are preserved around the entire circumference of the specimen PMU 26835. This occurrence of longitudinal color bands is known from other species of Isorthoceras (see Kröger et al. 2009; Fig. 28), but their significance for taxonomy is not known, because of the rarity of this type of preservation.

\section{Comparison}

This species is unique amongst species considered to belong to Isorthoceras in having exclusively longitudinal lirae. 


\section{Stratigraphic and geographic range}

Boda Limestone, late Katian, Dalarna, Sweden.

Isorthoceras wahlenbergi Niko, 2008

Figs 4C, 26, 28C

Isorthoceras wahlenbergi Niko, 2008: 195, pl. 6, fig. 1.1-6.

\section{Diagnosis}

Isorthoceras with circular conch cross section; smooth shell surface; weakly curved growth axis with siphuncle slightly eccentric on concave side of curvature; angle of expansion ca. $9^{\circ}$; mature body chamber with maximum diameter of $31 \mathrm{~mm}$ and two constrictions on body chamber cast; position of siphuncle shifting sightly toward the center during ontogeny; siphuncular segments pyriform to fusiform; with weakly developed endosiphuncular deposits; septal necks short, cyrtochoanitic. (Adopted from Niko 2008.)

\section{Type locality and horizon}

Jutjärn Quarry, Siljan district, Dalarna, Sweden; Boda Limestone, Boda Core Member, late Katian, Ordovician.

\section{Material examined}

Fifty-five specimens in the collections of the PMU: two specimens (PMU 26842, 26843), Unskarsheden, Dalarna; 53 specimens (PMU 26844-26896), Kallholn, Dalarna; all from Boda Limestone, late Katian.

\section{Description}

The species was described in detail by Niko (2008). Because I. wahlenbergi is one of the most common cephalopods in the Boda Limestone. Fifty-three specimens are available for study in the collections of the PMU. This material provides valuable additional data relating to the variability of some of the characters. Measurements of the angle of expansion reveal an increase in the expansion rate up to diameters of ca. $10 \mathrm{~mm}$, when an a mean angle of ca. $10^{\circ}$ is reached (Fig. 26). The nearly mature conch expands more slowly and reaches its adult diameter at ca. $30 \mathrm{~mm}$. The mean of all 47 measurements is $9.0^{\circ}\left(1^{\text {st }}\right.$ quantile $8.1^{\circ}, 3^{\text {rd }}$ quantile $\left.10.2^{\circ}, \mathrm{n}=47\right)$.

The chamber distance was measured in ten specimens. The chamber height is relatively small, with a mean height 0.23 of the corresponding conch height $\left(1^{\text {st }}\right.$ quantile $0.22,3^{\text {rd }}$ quantile $\left.0.26, n=10\right)$.

\section{Remarks}

Three fragments of I. wahlenbergi are preserved with a longitudinal color pattern. In specimen PMU 26862 the shell is perfectly smooth; at a conch cross section of ca. 18-22 mm dark reddish, irregularly spaced longitudinal bands occur with a distance of ca. 1-2 mm (ca. 100 would occur around circumference, Fig. 28C). In PMU 26850, a portion of the phragmocone with a diameter increasing from 17 to $13 \mathrm{~mm}$, the smooth shell is partly ornamented with striae with a width of ca. $0.2 \mathrm{~mm}$ and a distance of ca. $2 \mathrm{~mm}$ (ca. 50 would occur around circumference). The bands are irregularly carved within the surface of the shell, which is otherwise smooth, and are interpreted as diagenetically altered traces of a color pattern (Fig. 4C). A similar longitudinal color pattern is known from other species of Isorthoceras, such as I. tenuitextum (Hall, 1847), I. romingeri (Foerste, 1932) (see Ruedemann 1919; Foerste 1932: pl. 10; Kröger et al. 2009), I. heroyense comb. nov. and I. suave comb. nov. (see above, 
Fig. 28). Because color pattern is relatively rarely preserved, its relevance for species differentiation is not known at the present.

\title{
Comparison
}

This species constitutes a large Isorthoceras. It is similar in size to I. dalecarliense Kröger et al., 2011, from which it differs in having a smaller angle of expansion of ca. $6^{\circ}$ (Fig. 26). I. sociale from the Maquoketa Formation, late Katian of the north-central USA is similar in dimension and general outline, but differs in having a less expanded siphuncle and a smaller adult size of only $25 \mathrm{~mm}$.

Holland (1993) described and figured a number of specimens from the late Katian Kildare Limestone of Ireland under the name 'Orthoceras' gregarium J. De C. Sowerb, 1839. These specimens are similar to $I$. wahlenbergi in general conch shape, in septal spacing and siphuncle position, as well as in having a smooth surface, and probably must be synonymized with the latter. However, because the internal characters are not known from the Kildare Limestone cephalopods, a synonymization is impossible at this point.

\section{Stratigraphic and geographic range}

Boda Limestone-Glisstjärn Formation, late Katian-Hirnantian, Dalarna, Sweden (see discussion of I. dalecarlense, above).

\author{
Suborder Lituitina Dzik, 1984 \\ Family Sinoceratidae Shimizu \& Obata, 1935
}

Genus Tyrioceras Strand, 1934

\section{Type species}

Tyrioceras kjaerulfi Strand, 1934, Furuholmen, Asker District, Norway, Grimsøy Formation, late Katian, Late Ordovician; by original designation.

\section{Emended diagnosis}

Large straight, compressed to depressed conch cross section; ornamented with broad bands or narrower raised transverse lines, which form broad and well marked, but not very deep ventral sinus with ventrolateral and dorso-lateral salients, siphuncle eccentric; septal necks orthochoanitic, relatively long, siphuncular segments tubular.

\section{Remarks}

The external characters of this genus where described in detail by Strand (1934) and Frye (1982). Originally the diagnosis of the genus was based only on the type species. In order to include T. warburgae Frye, 1982, which is similar to the type in many aspects, but differs in having a depressed, more rapidly expanding conch, the diagnosis is emended.

The placement of Tyrioceras within the Lituitina, was formerly based on the characteristically curved ornamentation alone, and therefore was somewhat questionable. The details of the internal characters, now known from $T$. warburgae, support these earlier assumptions. The shape and extent of the cameral deposits in $T$. warburgae are very similar to those of other lituitins. A syn-vivo dissolution of the connecting ring, which is typical of lituitins, is indicated by epichoanitic deposits (Figs 29, 30). Additionally, voluminous epi-, hyposeptal and mural deposits, and relatively long septal necks are very characteristic for Lituitina. The assignment within the family of Sinoceratidae is after Dzik (1984). 
Tyrioceras cf. kjaerulfi Strand, 1934

Figs $8 \mathrm{~A}, 10 \mathrm{~B}, 29 \mathrm{~A}, \mathrm{C}, 30$

Tyrioceras kjaerulfi Strand, 1934: 50, pl. 6.

Tyrioceras kjerulfi - Dzik 1984: 133, 138, text-fig. 55.5.

\section{Diagnosis}

Tyrioceras with angle of expansion of $11^{\circ}$; compressed conch cross section; ornamented with marked sinuous transverse growth lines that form ventral, lateral, and dorsal sinuses, and relatively deep ventrolateral and dorsolateral salients. (Adopted from Strand 1934.)

\section{Type locality and horizon}

Furuholmen, Asker District, Norway, Grimsøy Formation (questionable), late Katian, Late Ordovician.

\section{Material}

One specimen from Kallholn, PMU 26897, Siljan district, Dalarna, Sweden; Boda Limestone, Boda Core Member, late Katian, Ordovician.

\section{Description}

Specimen PMU 26897 is a portion of a phragmocone $56 \mathrm{~mm}$ long with conch height and width increasing from 27 to $41 \mathrm{~mm}$ and 25 to $34 \mathrm{~mm}$, respectively. The angles of expansion are $14^{\circ}$ and ca. $9^{\circ}$, respectively, whereas the width/height ratio decreases from 0.93 apically to 0.83 adorally (Figs $8 \mathrm{~A}$, $10 \mathrm{~B})$. The relative chamber height is 0.4 , and the septal convexity is 0.25 of the corresponding conch height. The siphuncle is subcentrally positioned with a diameter of ca. 0.13 of the conch cross section. The connecting ring is not preserved, but the septal necks are orthochoanitic and relatively long with ca. 0.45 of the chamber height (Fig. 29A, C). Heavy epi-, hyposeptal and mural deposits are developed. Adapically, the deposits cover the apical septal necks, forming epichoanitic deposits (Fig. 30).

The conch surface is ornamented with transverse lirae, ca. 4-5 in a distance of $1 \mathrm{~mm}$. The spacing of the lirae varies periodically, forming bands with widths of ca. $4 \mathrm{~mm}$. The lirae form a shallow sinus on the prosiphuncular, and a more pronounced sinus on the antisiphuncular side of the conch.

\section{Remarks}

This species is based on a single, probably mature body chamber fragment only. Nothing is known about the ontogenetic and intraspecific variability of characters such as angle of expansion, conch cross section or ornamentation. The specimen PMU 26897, described above, is similar to Tyrioceras kjaerulfi with respect to the compressed conch cross section and the irregularly spaced transverse ornamentation. However, the type of the species differs in having a comparatively low angle of expansion $\left(11^{\circ}\right)$ and a lower width/height ratio $(0.79)$. The specimens are provisionally interpreted as conspecific.

\section{Stratigraphic and geographic range}

Grimsøy Formation (questionable), Asker District, Norway; Boda Limestone, Dalarna, Sweden, all late Katian, Late Ordovician.

Tyrioceras warburgae Frye, 1982

Fig. 29B

Tyrioceras warburgae Frye, 1982: 1282, pl. 2, figs 5-7, text-fig.5. 


\section{Emended diagnosis}

Tyrioceras with angle of expansion of $12-15^{\circ}$, with slightly depressed to slightly compressed conch cross section; ornamented with marked sinuous transverse growth lines that form ventral, lateral and dorsal sinuses, and relatively deep ventrolateral and dorsolateral salients.

\section{Type locality and horizon}

Kallholn, Siljan district, Dalarna, Sweden; Boda Limestone, late Katian, Ordovician.

\section{Material examined}

Eleven specimens in total: three specimens (PMU 26898-26900), the holotype (PMU 24747) and five paratypes (PMU 24748-24752), all from Kallholn; two specimens from Unskarsheden (PMU 26901, 26902), Siljan district, Dalarna, Sweden; Boda Limestone, latest Katian, Ordovician.
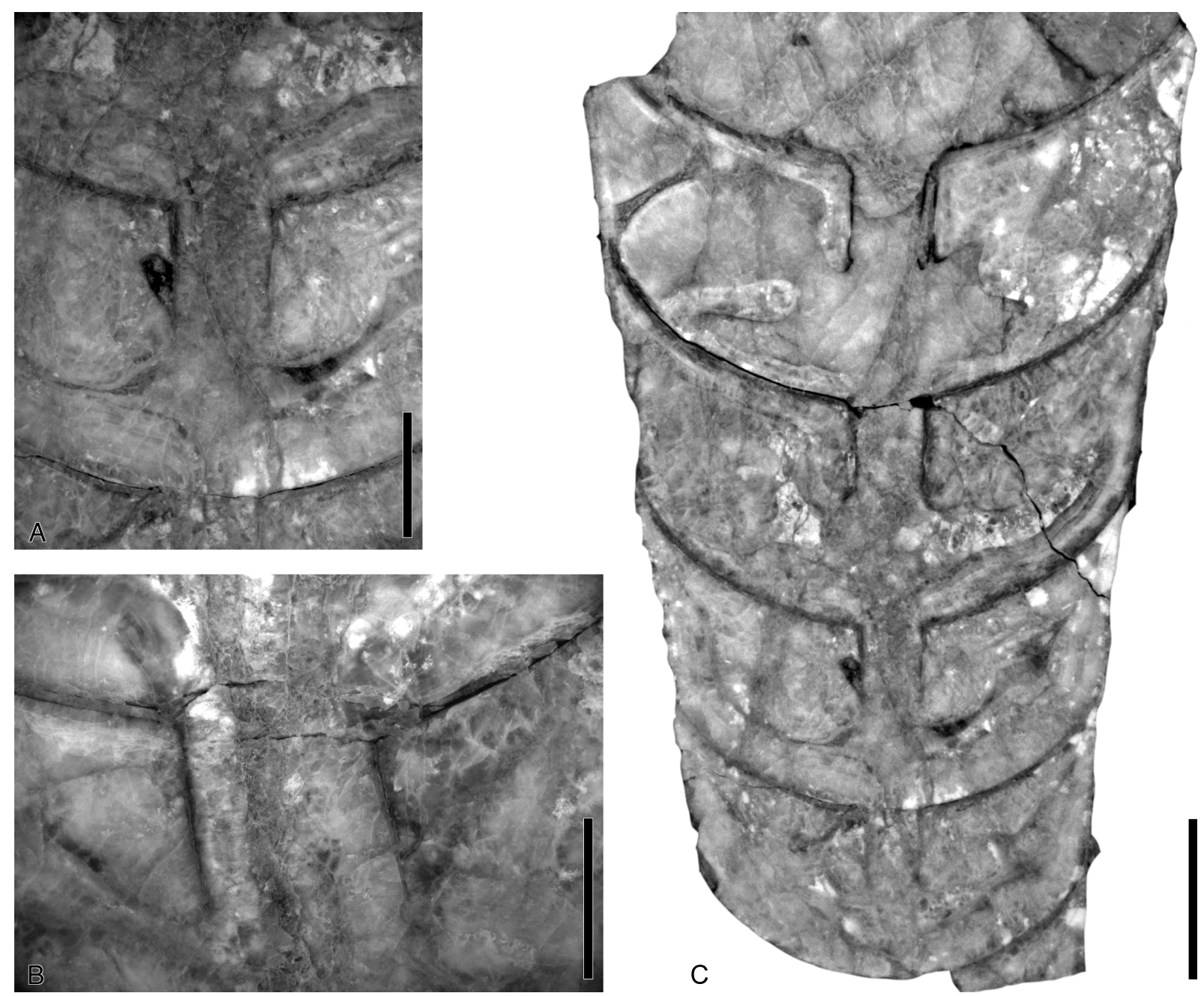

Fig. 29. Polished median sections of Tyrioceras Strand, 1934, Boda Limestone. A. Tyrioceras cf. kjaerulfi Strand, 1934, PMU 26897, Kallholn, detail of septal neck with massive endocameral and epichoanitic deposits and long orthochoanitic septal necks. B. Tyrioceras warburgae Frye, 1982, PMU 26900, Kallholn, detail of septal neck with epichoanitic deposits. C. Same specimen as in A, total fragment. Scale bars: A-B $=5 \mathrm{~mm} ; \mathrm{C}=10 \mathrm{~mm}$. 


\section{Description}

Frye (1982) described the ornamentation of this species in detail. Additional new details of the conch shape and internal characters are described herein.

The holotype is a $67 \mathrm{~mm}$ long portion of phragmocone with a circular diameter at conch cross sections increasing from 28 to $46 \mathrm{~mm}$, with an angle of expansion of $15^{\circ}$. In two of the paratypes (PMU 24748, 24750), width/height ratios are 0.94 (at width $32 \mathrm{~mm}$ ), 0.93 (at width $25 \mathrm{~mm}$ ) and 0.94 (at width 75 $\mathrm{mm})$, respectively.

Specimen PMU 26900 is a $65 \mathrm{~mm}$ long portion of a phragmocone with a conch height increasing from 34 to $47 \mathrm{~mm}$ (angle of expansion $11.3^{\circ}$ ). The conch cross section is slightly elliptically depressed, with

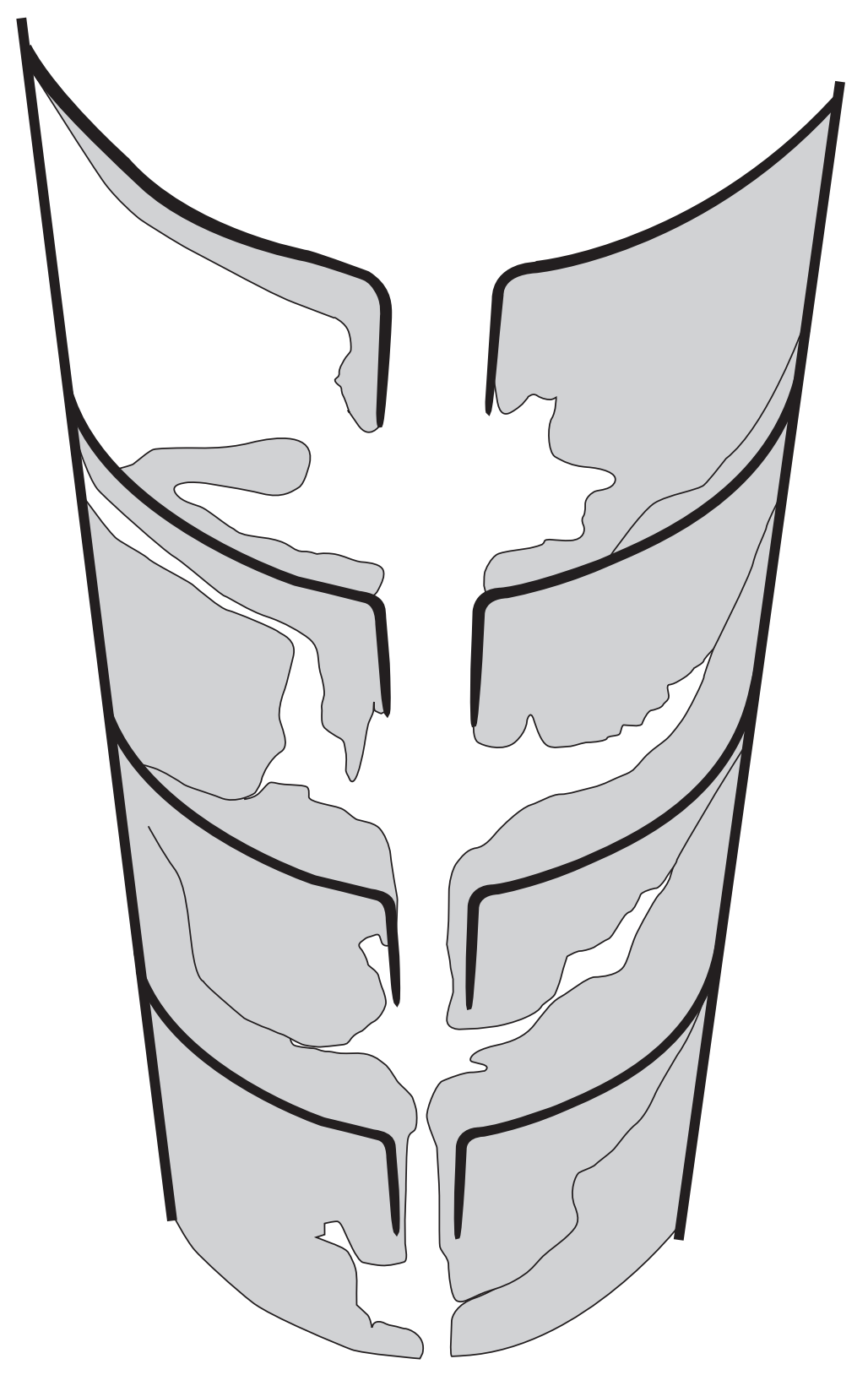

Fig. 30. Reconstruction of median section of Tyrioceras cf. kjaerulfi Strand, 1934, PMU 26897, Boda Limestone, Kallholn. Black = outer shell and septa; grey $=$ cameral deposits. 
a width/height ratio of 1.10 . The sutures are directly transverse, with a distance between two septa equal to ca. 0.4 of the conch height. The siphuncle is slightly eccentric, with a SPR of 0.43 and a diameter of 0.17 of the conch cross section. The connecting ring is not preserved. The septal necks are $6 \mathrm{~mm}$ long and orthochoanitic to suborthochoanitic. On the prosiphuncular side, the chambers are filled with heavy epi-, and hyposeptal and mural deposits, which are partially fused. The hyposeptal deposits cover the entire adapical/external surface of the septal neck (Fig. 29B).

\section{Remarks}

Frye (1982) did not include the shape of the cross section in the original diagnosis of this species. The conch cross section of the holotype is circular. Additionally, there are specimens with slightly compressed to slightly depressed conch cross section, which are identical to the type in all other features. The relatively low number of specimens in the collection does not allow for a proper evaluation of this character for classification purposes. Here, the variability in conch cross section is interpreted as intraspecific and the species diagnosis is emended accordingly.

\section{Comparison}

Tyrioceras kiaerulfi differs from $T$. warburgae in having a compressed conch cross section for its known length and generally in having a lower angle of expansion.

\section{Stratigraphic and geographic range}

Boda Limestone, late Katian, Dalarna, Sweden.

Order Tarphycerida Flower in Flower \& Kummel, 1950

Family Discoceratidae Dzik, 1984

Genus Discoceras Barrande, 1867

\section{Type species}

Clymenia antiquissima Eichwald, 1842, Kärdla, Hiiumaa Island, Estonia, presumably Vormsi/Pirgu Regional Stage ("Lyckholm stage" of Teichert 1930); by secondary designation (Schröder 1891).

\section{Diagnosis}

Gradually expanded tarphycerids with smooth to strongly annulated conch; impression zone slightly developed; subquadrate conch cross section; siphuncle central in initial half-volution, gradually shifting toward dorsal conch margin during later growth stages; thick connecting rings. (Adopted from Furnish \& Glenister 1964b.)

\section{Remarks}

The genus Schroederoceras Hyatt, 1894 was regarded as synonymous with Discoceras Barrande, 1867 by Sweet (1958) and Furnish \& Glenister (1964b). In the opinion of these authors, Discoceras included strongly annulated forms such as the type of Discoceras, Clymenia antiquissima Eichwald, 1842, as well as smooth conchs such as Lituites angulatus Saemann, 1852, the type of Schroederoceras. Because several species show transitional morphologies from weakly ornamented to strongly annulate, Schroederoceras and Discoceras are often difficult to distinguish and the position advocated by Sweet (1958), who discussed this issue in detail, is followed herein. Stumbur (1962) distinguished groups of discoceratids by their conch cross section and erected new generic names. However, Dzik (1984) already pointed out that the variation between the different shapes is continuous and sometimes changes within single specimens. Based on the known variability of the material from the Boda Limestone, it is impossible to distinguish different genera by conch cross section alone. 
Discoceras antiquissimum (Eichwald, 1842)

Fig. 31B

Clymenia antiquissima Eichwald, 1842: 33, pl. 3, figs 16, 17.

Lituites trapezoidalis Lossen, 1860: 25, pl. 1, fig. 2.

Clymenia antiquissima - Eichwald 1840: 15 (nomen nudum).

Lituites (Trocholites) antiquissimus - Schmidt 1861: 62, pl. 6, fig. 2a-g.

Lituites antiquissimus - Roemer 1861: 62, pl. 6, fig. 2f-g (non pl. 6, figs 2a-e = Discoceras roemeri Strand, 1934, see below). — Karsten 1869: 53, pl.19, fig. 7a-c. — Roemer 1885: 68, pl. 4, fig. 12.

Discoceras antiquissimum - Foerste 1925: 17, 58, pl. 18, fig. 1. - Strand 1934: 32, pl. 2, figs 4, 11, pl. 4, figs 2, 3, pl. 13, fig. 9. - Thorslund 1936: pl. 2, fig. 11. - Balashov 1953: 265, pl. 12, fig. 1a, b. Sweet 1958: 99, text-fig. 13q. — Neben \& Krueger 1973: pl. 77, figs 24, 25. — Dzik 1984: 42, text-figs 9c-d, 12.39, pl.7, fig. 1.

Discoceras antiquissima - Hucke \& Voigt 1967: 58, pl. 15, fig. 1.

\section{Diagnosis}

Discoceras with adult sizes more than $130 \mathrm{~mm}$, WER of ca. 1.9 decreasing with increasing conch size; whorl cross section slightly depressed with WWI 1.2-1.5 becoming less depressed in maturity, broadly reniform in juvenile stages, rounded trapezoidal with venter wider than dorsum in later groth stages; free mature body chamber with constriction near aperture; ornamented with prominent ribs, one to two ribs per distance between two septa; siphuncle close to dorsal conch margin, ca. 0.15-0.17 of whorl height, septal necks orthochoanitic. (Adopted from Strand 1934.)

\section{Type locality and horizon}

Kärdla, Hiiumaa Island, Estonia, presumably Vormsi/Pirgu Regional Stage ("Lyckholm stage" of Teichert 1930).

\section{Material}

Two specimens, PMU 24739 and NRM-PZ Mo 8745, Kallholn, late Katian, Late Ordovician.

\section{Description}

This species was described in detail by Strand (1934). The specimen from the Boda Limestone is documented in order to add detail regarding the morphological variability of the species. The specimen with a maximum conch diameter of $92 \mathrm{~mm}$ is a fragment with three whorls, lacking the free part representing the mature stage. The maximum whorl height is ca. $22 \mathrm{~mm}$ and the maximum width $25 \mathrm{~mm}$ (WWI 1.14), the whorl expands with a WER of 1.89 . The conch is prominently annulated, with ca. 30 sharply crested ribs per $360^{\circ}$ revolution. The ribs slope slightly adapically toward the venter and form an angular v-shaped sinus on the venter. In addition to the conch annulation, the shell is ornamented with fine, irregularly spaced, transverse growth lines parallel to the annulations.

\section{Remarks}

It is very probable that the specimen NRM-PZMo 8745 is thatreferred to by Strand(1934:36) from the Boda Limestone.

\section{Comparison}

This species, with its prominent juvenile to adult annulation, is unique within Discoceras. 


\section{Stratigraphic and geographic range}

Bønsnes Formation, Ringerike district, "Gastropod Limestone", Oslo-Asker, and Skien-Langesund district, Norway (Strand 1934); erratic limestone boulders from northern Germany (Hucke \& Voigt 1967), and erratic limestone boulders from Vormsi/Pirgu Regional Stage ("Lyckholm stage"), Zawidowice, Poland (Dzik 1984); Vormsi/Pirgu Regional Stage ("Lyckholm stage"), Estonia (Teichert 1930; Balasov 1953); Boda Limestone, Dalarna, Sweden; all late Katian.

\section{Discoceras roemeri Strand, 1934}

Figs $31 \mathrm{~A}, 32,33$

Discoceras roemeri Strand, 1934: 38, 42-43, pl. 2, figs 6a-b, 7, pl. 5, figs 1, 2.

Schroederoceras balaschovi Stumbur, 1956: 181, pl. 1, figs 5, 6.

Lituites antiquissimus - Roemer 1861: 62, pl. 6, fig. 2a-e (non Discoceras antiquissimum (Eichwald, 1840)).

Discoceras angulatum - Mutvei 1957: text-fig. 12, pl. 8.

Discoceras roemeri - Sweet 1958: 99, 102, text-fig. 13p. — Dzik 1984: 41, 44, text-figs 10, 12.43, pl. 6 , figs 5,6 .

Schroederoceras roemeri - Stumbur 1962: 136, text-fig. 2.4.

Rectanguloceras balaschovi-Stumbur 1962: 142, text-fig. 2.9.

Rectanguloceras (Discoceras) cf. roemeri - Neben \& Krueger 1973: pl. 65, figs 1, 2.

\section{Diagnosis}

Discoceras with large adult sizes of up to $150 \mathrm{~mm}$, WER of 1.9-2.5, decreasing with increasing conch size; whorl cross section slightly depressed with WWI 1.1-1.3, rounded subquadratic with venter not wider than dorsum; body chamber nearly $180^{\circ}$ long, free in mature growth stages and becoming
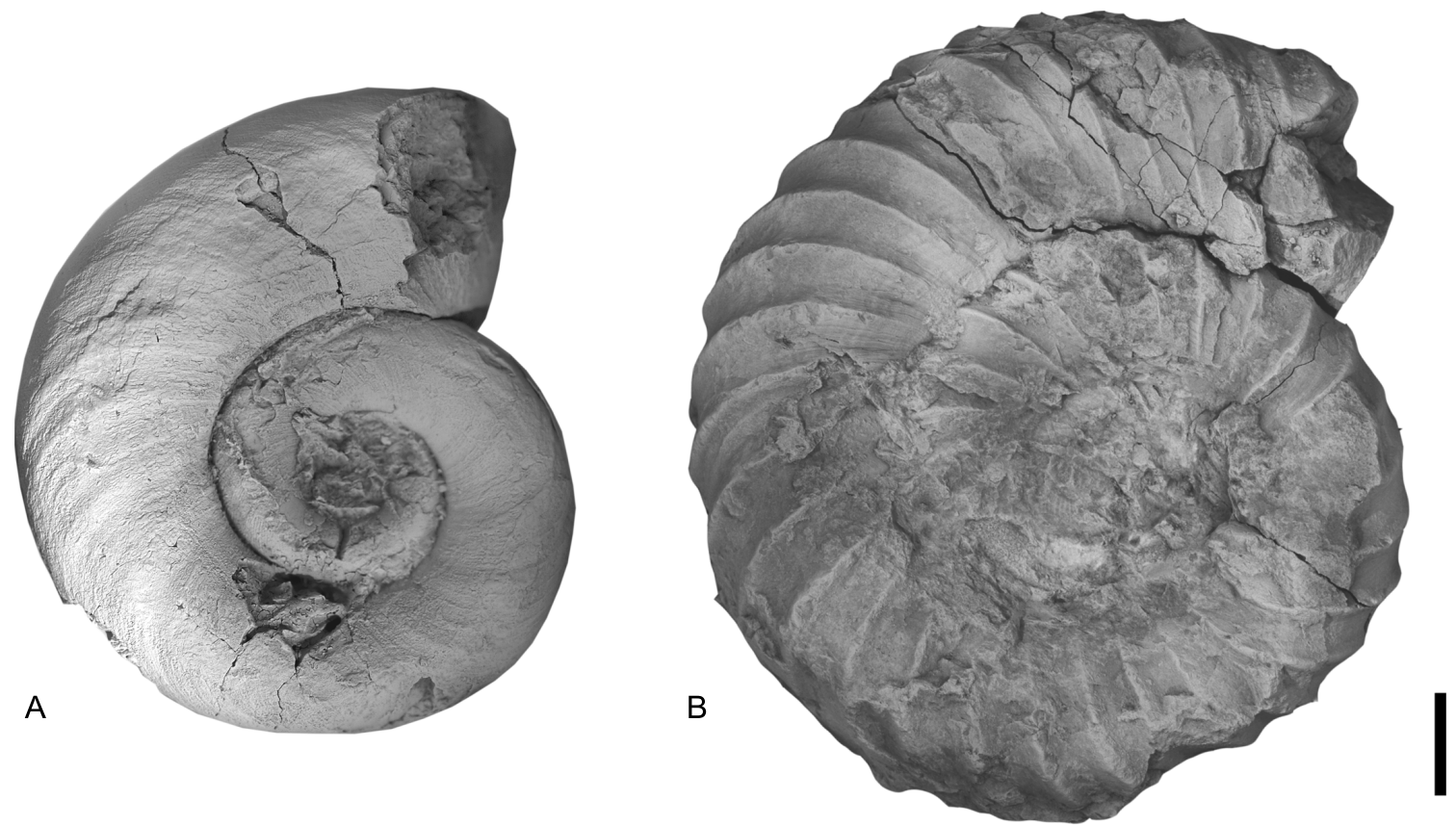

Fig. 31. Discoceratids of the Boda Limestone of Kallholn. A. Discoceras roemeri Strand, 1934, PMU 26903. B. Discoceras antiquissimum (Eichwald, 1842), NRM-PZ Mo 8745. Scale bar $=10 \mathrm{~mm}$ for both figures. 
markedly higher during matures stages; ornamented with irregularly spaced costae and shallow ribs. (Adopted from Strand 1934.)

\section{Type locality and horizon}

Frognøya, Tyrifjorden, Norway, Sørbakken Formation (Stage 4cß), late Katian, Ordovician.

\section{Material}

Four specimens (PMU 26903-26906), Kallholn; one specimen (PMU 26907), Skålberget, Dalarna, Boda Limestone; one specimen (PMU 26908), Amtjärn, Dalarna, Johnstorp Formation; all late Katian, Late Ordovician.
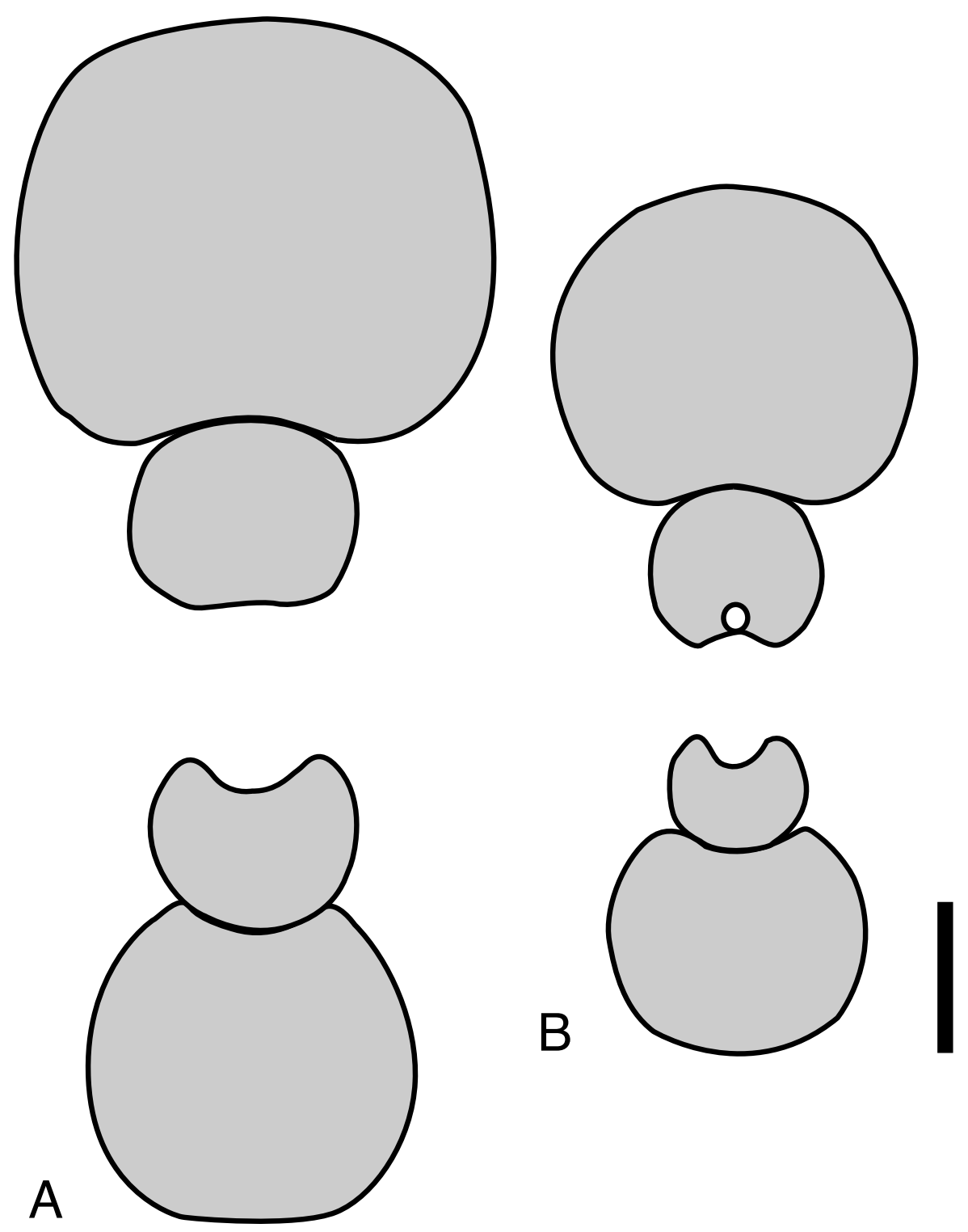

Fig. 32. Median cross sections of Discoceras roemeri Strand, 1934, Boda Limestone, Kallholn. A. PMU 26903. B. PMU 26904. Scale bar $=10 \mathrm{~mm}$ for both figures. 


\section{Description}

This species was described in detail by Strand (1934). The specimens from the Boda Limestone provide additional data regarding the ornamentation and the variability of the general conch shape. In specimen PMU 26903 the conch surface is well preserved (Fig. 31A). The maximum diameter of this specimen is $72 \mathrm{~mm}$ with a maximum whorl height of $24 \mathrm{~mm}$ and width of $29 \mathrm{~mm}$ (WWI 1.21); the WER of the specimen is 2.16 . The whorl cross section is subquadratic with a ca. $12 \mathrm{~mm}$ wide, slightly rounded flattened venter, rounded umbilical shoulders and a shallow impression zone. The specimen is ornamented with ca. 17 shallow, slightly irregularly marginally spaced ribs on the outer whorl. The ribs occur only on the umbilical shoulders, not on the venter, which is almost flat. Narrowly spaced, pronounced growth lines or costae run parallel to the ribs and form a pronounced u-shaped hyponomic sinus.

The whorl expansion rate varies comparatively strongly amongst the five specimens from the Boda Limestone, with a maximum of 2.56 in specimen PMU 26904 (Fig. 32B), a specimen which agrees in all features with other specimens assigned to $D$. roemeri.

\section{Remarks}

Strand (1934: 46) described some variation in his specimen of D. roemeri. Within this material, the type, which is from the Sørbakken Formation, differs from younger specimens of the "Gastropod Limestone" in having a narrower venter. The Boda Limestone specimens are most similar to the specimen of the Gastropod Limestone and to the specimen figured by Roemer (1861: pl. 6, fig 2a). This is also apparent in the diagrammatic representation of the whorl expansion in Fig. 33, where the variation of the specimens from the Boda Limestone is closer to the variation of the specimen figured by Roemer (1861).

\section{Comparison}

Several species of Discoceras, described from the Gastropod Limestone of the Oslo area (Strand 1934), are very similar to the specimens assigned to $D$. roemeri herein. Generally, these species differ in having a lower expansion rate of ca. 1.8-1.9. Among them, $D$. angulatum is most similar to $D$. roemeri with respect to the conch cross section. $D$. angulatum also has similarly rounded umbilical shoulders, but in
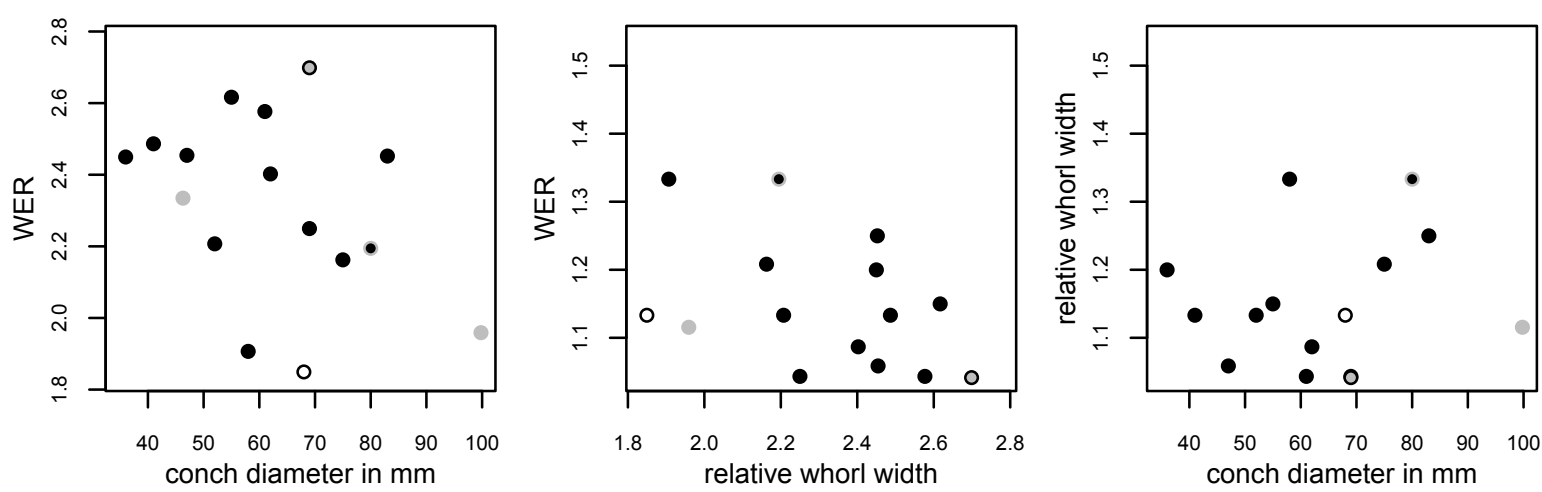

Fig. 33. Morphological variation in Discoceras roemeri Strand, 1934. Black dots $=$ specimens of the Boda Limestone. Black dot with grey margin $=$ Rectanguloceras balaschovi Stumbur, 1962. Grey dots $=$ Lituites antiquissimus of Roemer (1861: pl. 6, figs 2a-e). Grey dot with black margin $=$ Discoceras roemeri of Dzik (1984: pl. 6, figs 5,6). White dot with black circle $=$ Discoceras roemeri of Strand (1934: pl. 5, fig. 1). WER = whorl expansion rate. 
contrast to $D$. roemeri the width of the ventral side of the whorl is always less than that of the dorsal side, and appears to be flatter.

The diagrammatic representation of the morphological variation of different specimens assigned to D. roemeri and the comparison of cross sections reveal that Schroederoceras balaschovi Stumbur, 1956 from the Pirgu Stage of Estonia and Discoceras vasegaardense Rasmussen \& Surlyk, 2012 from the late Katian Lindegård Formation of Bornholm, Denmark are well within the range of variation of D. roemeri and must be synonymized with the latter (Fig. 33). However, because details of the cross section of $D$. vasegaardense are not known and the ribbing in this species appears to be stronger than in specimens assigned to $D$. roemeri it cannot be synonymised with the latter. On the other hand, Schroederoceras balaschovi is interpreted as a junior synonym of $D$. roemeri, herein.

\section{Stratigraphic and geographic range}

Venstøp and Sørbakken formations, Ringerike district, and Venstøp and Grimsøy formations, Oslo-Asker district, upper Herøya Formation ("Gastropod Limestone"), Skien-Langesund district, Norway (Strand 1934); erratic limestone boulders from Vormsi/Pirgu Regional Stage ("Lyckholm stage"), Zawidowice, Poland (Dzik 1984); Vormsi/Pirgu Regional Stage ("Lyckholm stage"), Estonia (Teichert 1930; Stumbur 1956, 1962); Boda Limestone, Dalarna, Sweden; all late Katian.

Order Barrandeocerida Flower in Flower \& Kummel, 1950

\section{Remarks}

The order Barrandeocerida was not accepted by Dzik (1984: 46), who placed the genus Barrandeoceras Hyatt, 1884 within the Tarphyceratidae, or by Flower (1984: 1377), who placed the family Barrandeoceratidae within the Tarphycerida. However, Barrandeoceras and similar forms, which were assigned to the Barrandeocerida by Flower \& Kummel (1950) and Sweet (1964a) are clearly distinguished from Tarphycerida in having a thin-walled orthocerid-like siphuncle with achoanitic to cyrtochoanitic septal necks. The differences between the connecting ring structure and morphology in tarphycerids and barrandeocerids were examined and discussed by Mutvei \& Dunca (2011), renewing earlier hypotheses (see Flower 1984) of an orthocerid ancestry for the Barrandeocerida (see discussion below).

Family Uranoceratidae Hyatt in Zittel, 1900

Genus Siljanoceras gen. nov.

urn:Isid:zoobank.org:act:71F25FD0-6E8D-4753-9CA2-B0137EC6D22B

\section{Type species}

Siljanoceras varians gen. et sp. nov., Kallholn, Dalarna, Sweden, Boda Limestone, Boda Core Member, late Katian, Ordovician.

\section{Diagnosis}

Rapidly expanding curved conchs with circular to slightly depressed conch cross section; mature body chamber with clearly depressed cross section; nearly straight in late growth stages, more strongly curved in early growth stages, continuously expanding in height, slightly bulbous in width, with decreasing width near aperture; cross section more rounded on dorsal side and slightly flattened on venter; ornamented with fine longitudinal striae and irregularly spaced faint growth lines, which form shallow sinus on venter; siphuncle eccentrically positioned at convex side of conch curvature; siphuncular segments barrel-shaped, widely expanded; septal necks achoanitic. 


\section{Etymology}

From Lake Siljan, Dalarna, Sweden.

\section{Remarks}

The decreasing conch curvature during maturity, the position and shape of the siphuncle, the ventromyarian periphract (Fig. 34) and the longitudinal ornamentation are characters that are typical of the Uranoceratidae and justify an assignment of this new genus within this family.

An apical fragment, PMU 26918, questionably is from a Siljanoceras gen. nov. (Fig. 35E-F). It can be described as following: The tip of the fragment is cup-shaped, at ca. $2 \mathrm{~mm}$ from the tip the conch height is $4.5 \mathrm{~mm}$, the width $4.3 \mathrm{~mm}$. The conch surface is ornamented with a shallow rounded annulation (ca. 3 annuli per millimetre) and faint longitudinal striae. The annuli have a shallow hyponomic sinus on the concave side of the shell curvature. The conch is very slightly curved and expands with an angle of ca. $33^{\circ}$ and is nearly circular in conch cross section at a conch diameter of ca. $9 \mathrm{~mm}$. The siphuncle is positioned close to the conch margin and is ca. 0.08 of the conch diameter.

\section{Comparison}

Among other openly coiled Barrandeocerida, this genus is unique in its combination of a siphuncle that lies toward the conch wall on the convex side of the conch curvature and the conch cross section being more rounded on the dorsum (concave side of conch curvature). In its non-annulated, longitudinally striated shell surface, it is most similar to Uranoceras Hyatt, 1884, but differs from this genus in being more openly coiled and more rapidly expanding.

\section{Stratigraphic and geographic range}

Boda Limestone, late Katian, Dalarna, Sweden.

\section{Species included}

Siljanoceras varians sp. nov., Siljanoceras sp. A.

Siljanoceras varians $\mathrm{sp}$. nov.

urn:1sid:zoobank.org:act:E4162038-CB02-4BDC-B8B3-EDE3417D2980

Figs 34, 35A-D, G-I, 36C-D, 37, 38

\section{Diagnosis}

Siljanoceras gen. nov. with angle of expansion of ca. $25^{\circ}$, with circular to slightly depressed conch cross section; siphuncle eccentrically positioned with distance of ca. 0.3 of corresponding conch diameter from conch margin at convex side of conch curvature; siphuncular segments barrel-shaped, widely expanded within chambers with diameters of $0.16-0.2$ of corresponding conch cross section; septal necks achoanitic.

\section{Etymology}

Refers to the relatively high morphological variability, Latin variabilis, of this species.

\section{Type material}

\section{Holotype}

PMU 26909. 


\section{Paratypes}

Seven paratypes (PMU 26910-26916), Kallholn, Dalarna, Sweden, Boda Limestone, Boda Core Member, late Katian, Ordovician.

\section{Type locality and horizon}

Kallholn, Dalarna, Sweden, Boda Limestone, Boda Core Member, late Katian, Ordovician.

\section{Description}

The holotype is a fragment of a slightly curved mature body chamber (Figs 34, 35A-B, G). The elliptically compressed body chamber has an apical height of $58 \mathrm{~mm}$ and width of $67 \mathrm{~mm}$ (width height ratio = 1.16), an adoral height of $92 \mathrm{~mm}$ against a width of $105 \mathrm{~mm}$. The conch margin is flattened at the convex side of the conch curvature and more rounded at the concave side. In lateral view the conch continuously expands with an angle of $23^{\circ}$ and its width expansion decreases over the entire length of the specimen with an overall angle for the preserved portion of expansion of $25^{\circ}$. In the adoral $10 \mathrm{~mm}$ of the fragment the conch width decreases slightly, giving the body chamber a slightly bulbous shape.

The siphuncle is eccentrically positioned with diameter of the septal perforation of $3 \mathrm{~mm}(0.05$ of corresponding conch height). The siphuncle is situated at a distance of ca. $18 \mathrm{~mm}$ from the conch margin at the convex side of the conch curvature, where the conch height is $58 \mathrm{~mm}$ (SPR 0.31).

The shell surface is nearly smooth. Fine, irregularly spaced, rounded growth lines or striae form a very shallow salient on the lateral sides and faint traces of longitudinal striae are preserved. The suture of the last chamber is transverse. The septum is shallow and cap-shaped.

At the base of the body chamber the periphract is preserved as an impression on the internal mould (Fig. 34). The periphractic imprint forms a narrow ca. $5 \mathrm{~mm}$ wide band with an irregular margin on the lateral and dorsal (antisiphuncular) sides. Ventrally, a pair of adjacent impressions, each ca. $13 \mathrm{~mm}$ wide, occur.

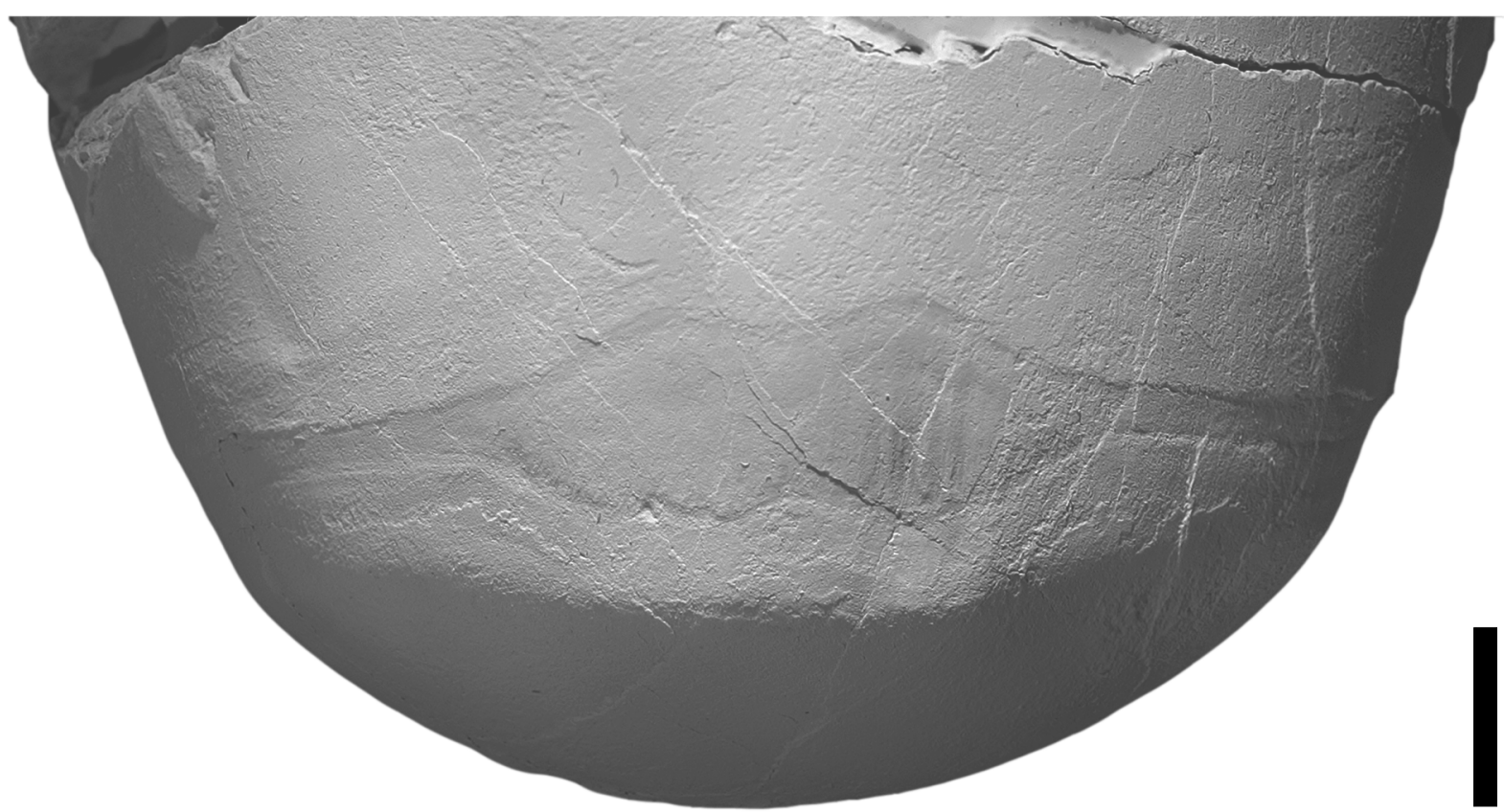

Fig. 34. Muscle attachment scars from ventromyarian periphract in Siljanoceras varians sp. nov., PMU 26909, holotype, Kallholn. Scale bar $=10 \mathrm{~mm}$. 
The fine, longitudinally and transversely striated ornamentation is best preserved in specimen PMU 26913 (Fig. 37). In this specimen the longitudinal elements are preserved as fine, raised striae with a distance of ca. $0.2 \mathrm{~mm}$ at a conch height of ca. $30 \mathrm{~mm}$.

The chamber height is ca. 0.16 of the corresponding conch height (based on measurements on specimens PMU 26913 and 26915). The sutures are straight and directly transverse.

Details of the internal morphology are preserved in specimen PMU 26915, which is a fragment consisting of five chambers and part of a body chamber, with conch height increasing from 19 to $35 \mathrm{~mm}$ (Fig. 36C). The septa are directly transverse and ca. 0.17 of the conch height in distance. The septal perforation is eccentrically positioned at a distance of $5 \mathrm{~mm}$ apically, and $7 \mathrm{~mm}$ adorally (SPR ca. 0.25-0.26). The septal necks are achoanitic. The siphunclular segments are barrel-shaped, widely expanded. In the adapical-most chamber the siphuncle is significantly less expanded ( 0.16 of corresponding conch cross section) than in the adoralmost chamber (relative siphuncular diameter 0.2).

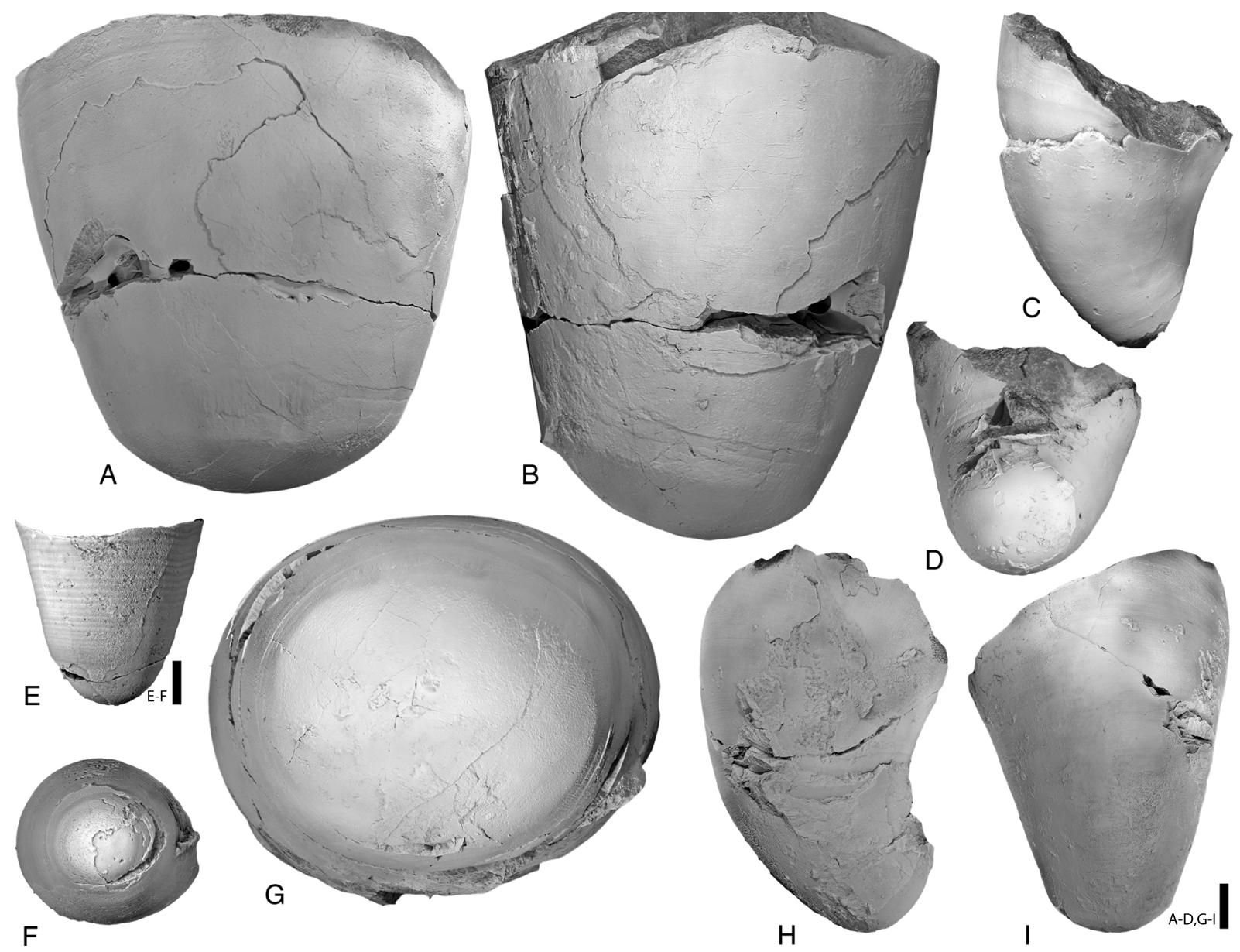

Fig. 35. Siljanoceras gen. nov., Kallholn, Boda Limestone. A-D. Siljanoceras varians sp. nov. A. PMU 26909, holotype, mature body chamber, view from prosiphuncular side. B. Same specimen, lateral view. C. PMU 26913, lateral view. D. Same specimen, adapical view. E-F. Apical fragment of Siljanoceras? sp., PMU 26918. E. Lateral view. F. Adapical view. G-I. Siljanoceras varians sp. nov. G. Same specimen as in A-B, adapical view. H. PMU 26914, lateral view. I. Same specimen view from prosiphuncular side. Scale bars: A-D, G-I $=10 \mathrm{~mm}$; E-F $=2 \mathrm{~mm}$. 


\section{Remarks}

Some of the specimens assigned to this species were slightly crushed during deposition and as a consequence show aberrant conch cross sections. Therefore, the variability in conch cross section shape and angle of expansion is difficult to evaluate. Generally, a trend of increasing compression of the conch cross section can be ascertained (Fig. 35). Based on the limited material available it seems reasonable
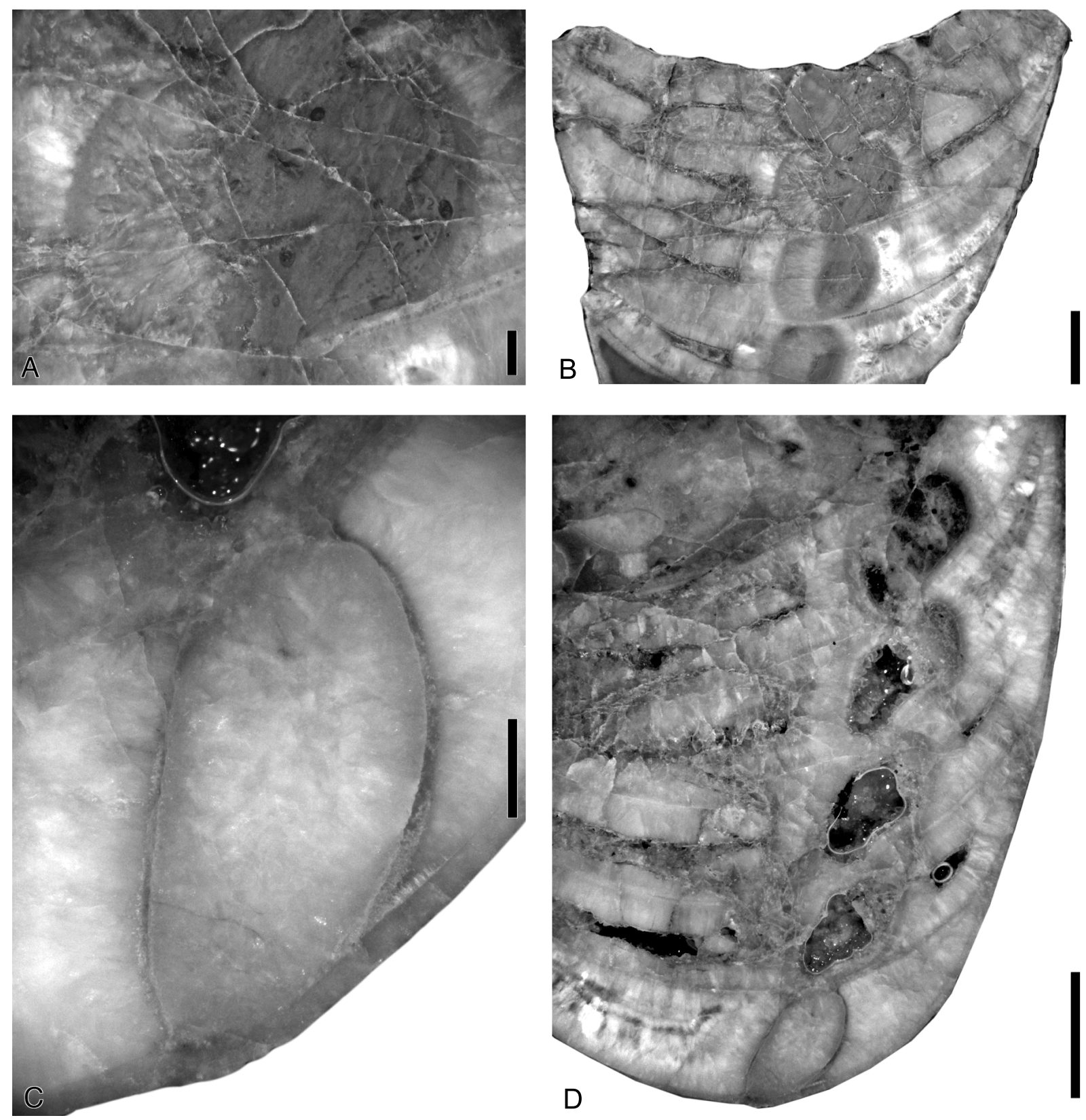

Fig. 36. Polished median sections of Siljanoceras gen. nov., Boda Limestone. A. Detail of siphuncular segment of Siljanoceras sp. A, PMU 26917, Kallholn. B. Same specimen, total view. C. Siljanoceras varians sp. nov., PMU 26915, Kallholn; detail of apical-most siphuncular segment, section not perfectly in median plane, with adapical septal perforation not preserved. D. Same specimen, total view. Scale bars: $\mathrm{A}, \mathrm{C}=1 \mathrm{~mm}$; $\mathrm{B}, \mathrm{D}=5 \mathrm{~mm}$. 
to assume that the conch cross section varies from nearly circular to slightly depressed (Fig. 38) and the angle of expansion varies across the sample between 23 and $31^{\circ}$ (Fig. 38).

\section{Stratigraphic and geographic range}

Boda Limestone, late Katian, Dalarna, Sweden.

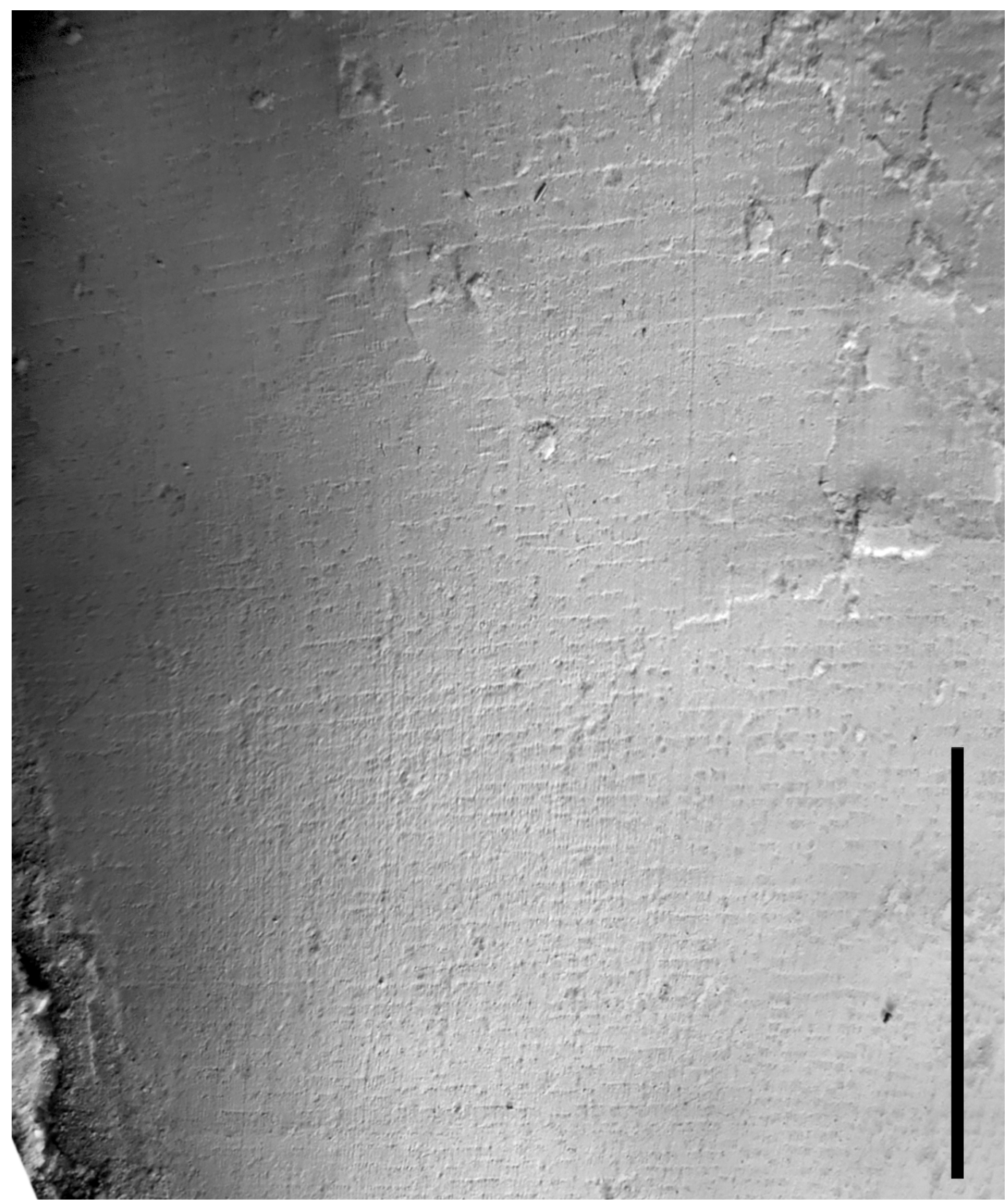

Fig. 37. Detail of ornamentation of Siljanoceras varians sp. nov., PMU 26913, Kallholn, Boda Limestone; position of apex down. Scale bar $=10 \mathrm{~mm}$. 


\section{Siljanoceras sp. A.}

Figs 36A-B, 38

\section{Material}

One specimen (PMU 26917), Kallholn, Siljan District, Sweden; Boda Limestone, Boda Core Member, late Katian.

\section{Description}

Specimen PMU 26917 is a mildly deformed portion of a slightly curved phragmocone, $23 \mathrm{~mm}$ long with a conch height of ca. 22-40 mm and a conch width of ca. 20-40 mm (angle of expansion ca. $38^{\circ}$ ) (Fig. $36 \mathrm{~A}, \mathrm{~B})$. The original shape of the conch cross section is difficult to evaluate, but was probably slightly depressed. The conch surface is poorly preserved and no signs of ornamentation are visible. The sutures are nearly transverse and have a distance of ca. 0.17 of the corresponding conch cross section.

The position of the septal perforation is eccentric (SPR 0.4). The siphuncular segments are barrel-shaped and widely expanded with maximum diameter of ca. 0.18 of the corresponding conch cross section. The septal necks are achoanitic.

\section{Remarks}

This fragmentarily preserved specimen differs from Siljanoceras varians gen. et sp. nov. in having a less curved, more expanded conch with a less eccentric siphuncle, that appears slightly more expanded within the shell. The general conch form is similar to that of Siljanoceras gen. nov. and it is therefore assigned to this genus. However, a species determination is impossible based on this imperfectly known specimen.

Genus Warburgoceras gen. nov.

\section{urn:1sid:zoobank.org:act:7BD9C0A9-AFD0-4AD8-B910-BFC3E32AD603}

\section{Type species}

Cyrtoceras longitudinale Angelin in Angelin \& Lindström, 1880, Kallholn, Dalarna, Sweden, Boda Limestone, Boda Core Member, late Katian, Ordovician; by montotypy.
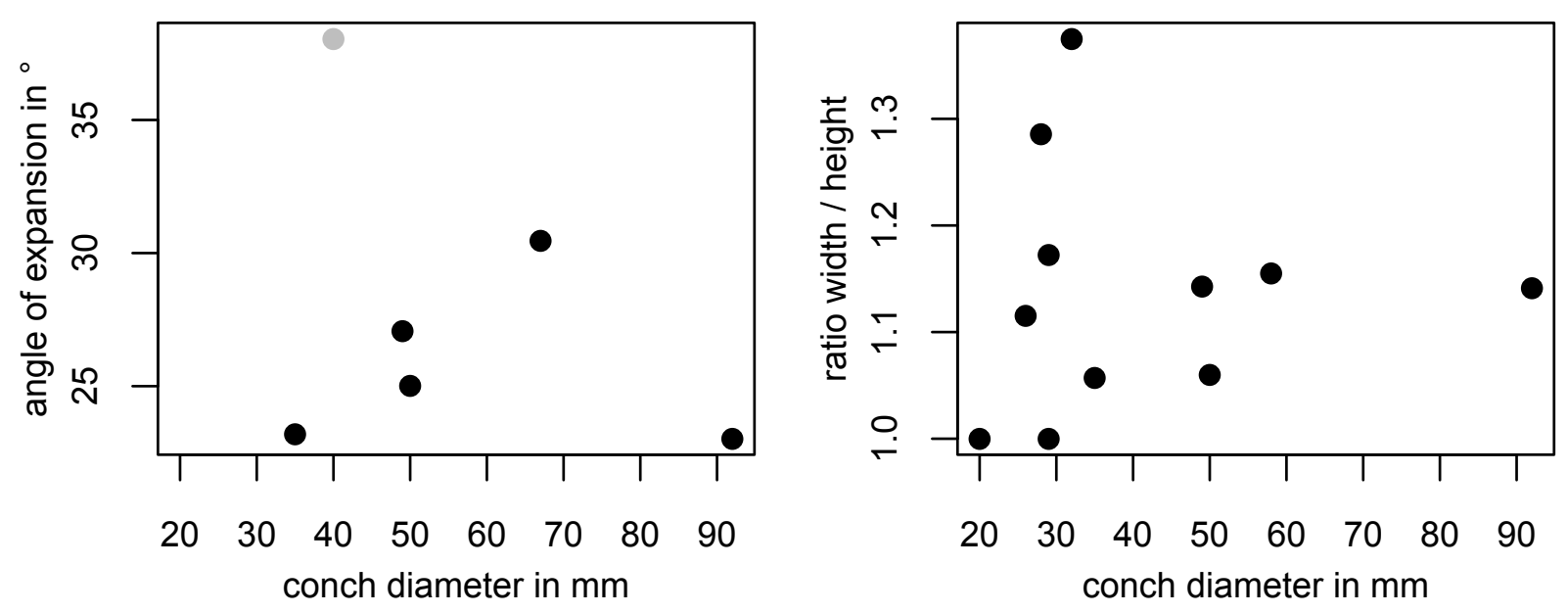

Fig. 38. Morphological variation of Siljanoceras gen. nov. Black dots = Siljanoceras varians sp. nov.; grey dot $=$ Siljanoceras $\mathrm{sp}$. A. 


\section{Diagnosis}

Continuously expanding gyrocones with circular, slightly compressed or slightly depressed cross section; angle of expansion in premature stages ca. $13^{\circ}$, decreasing during growth; ornamented with fine, irregularly spaced growth lines that form broad, shallow sinus on convex side of conch and with fine irregularly spaced longitudinal striae; mature body chamber with only weak terminal constriction; sutures straight and nearly directly transverse, with shallow lobe on prosiphuncular side of conch; ca. 4-5 chambers per distance similar to corresponding conch height; siphuncle eccentrically positioned, with SPR of ca. 0.1 at convex side of conch curvature; siphuncular segments slightly expanded within chamber, siphuncle diameter ca. 0.09 of corresponding conch cross section; connecting ring thin; septal necks short, loxochonoanitic-suborthochoanitic.

\section{Etymology}

In honor of Elsa Warburg (1886-1953), a Swedish paleontologist who published her doctoral thesis on the trilobites of the Boda Limestone (Warburg 1925) and collected most of the cephalopods of the Boda Limestone during the first decades of the $20^{\text {th }}$ Century.

\section{Remarks}

The position and shape of the siphuncle and the longitudinal ornamentation are characters that are typical of the Uranoceratidae and justify an assignment of this new genus within this family.

\section{Comparison}

Deckeroceras Foerste, 1935 from the late Katian Fernvale Formation of Oklahoma is most similar to Warburgoceras gen. nov. in general conch shape, but the body chamber is more inflated in the former, the siphuncle is more expanded and less eccentric, and the features of the external shell are not known. It is possible that Warburgoceras gen. nov. is a subjective junior synonym of Deckeroceras. However, since no details of the external shell are known from the latter and the types of both genera differ in some details, Warburgoceras gen. nov. is erected herein.

Warburgoceras gen. nov. differs from Uranoceras Hyatt, 1884 in having a nearly circular conch cross section, non-lobate, directly transverse sutures and in beeing more openly curved.

\section{Stratigraphic and geographic range}

Boda Limestone, late Katian, Dalarna, Sweden.

\section{Species included}

Type species only.

Warburgoceras longitudinale (Angelin in Angelin \& Lindström, 1880) comb. nov. Figs 18F, 39C

Cyrtoceras longitudinale Angelin in Angelin \& Lindström, 1880: 11, pl. 16, fig. 5.

Uranoceras (?) longitudinale - Mutvei 1957: 245, text-figs 6c, 7b, 10, 11, 20, 21, pl. 4, fig. 3, pls 6, 7, 17, 18. — Dzik \& Korn 1992: 84, 85, text-fig. 1.

Uranoceras longitudinale - Dzik 1984: 150, 154, text-fig. 59.2.

\section{Diagnosis}

Same as for genus by monotypy. 


\section{Type locality and horizon}

Osmundsberget, Dalarna, Sweden, Boda Limestone, Boda Core Member, late Katian, Ordovician.

\section{Material}

Four specimens, two from Kallholn (PMU 26919, 26921), one from Osmundsberget (NRM Mo 154065) and one from Unskarsheden (PMU 26920); Boda Limestone, late Katian, Dalarna, Sweden.

\section{Remarks}

This species was extensively described by Mutvei (1957). Additionally, the ventromyarian periphract was figured in three specimens with the mature body chamber preserved (Mutvei 1957: pl. 4.3, fig. 4; pls $6,7)$. Two more specimens with complete mature body chambers are in the collections of the NMR and PMU. Both body chambers are nearly identical in maximum conch height $(58 \mathrm{~mm})$, which is reached at the peristome. The body chamber contracts only very slightly close to the peristome and has a length of 90-100 mm (NRM Mo 154065, PMU 26919) (height/length ratio of body chamber ca. 0.6).

\section{Comparison}

Warburgoceras longitudinale comb. nov. is very similar to Redpathoceras bullatum sp. nov. with respect to ornamentation (both species have a similar distinctively longitudinally lirate surface; Fig. 18F), and are identical in angle of expansion, conch curvature, conch cross section and mature size (Fig. 39C). They differ, however, in two main aspects: (1) the mature body chamber of $R$. bullatum sp. nov. is inflated, with a maximum height at the mid-length, whereas the body chamber of $W$. longitudinale comb. nov. opens gradually, (2) the conch of $R$. bullatum sp. nov. displays deeply concave septa of truncation at regular distances. This similarity strongly suggests a close phylogenetic relationship between the two species, genera and higher taxa to which they belong (see discussion above).

\section{Stratigraphic and geographic range}

Boda Limestone, late Katian, Dalarna, Sweden.

Order Ascocerida Kuhn, 1940

Family Ascoceratidae Barrande, 1867

Genus Schuchertoceras Miller, 1932

\section{Type species}

Ascoceras anticostiensis Billings, 1866. Junction cliff, Anticosti Island, Canada. Probably the Ellis Bay Formation, Hirnantian, Late Ordovician; by original designation.

\section{Diagnosis}

Ascoceratid cephalopods with basal non-ascoceroid septum between septum of truncation and the first ascoceroid septum in mature conch. (Adopted from Frye 1982.)

Schuchertoceras fryi sp. nov. urn:lsid:zoobank.org:act:BA02C2EE-982A-483B-90DF-46E5E5F80FD4 Figs $10 \mathrm{~F}, 39 \mathrm{~F}$

Schuchertoceras troedssoni - Frye 1982: 1280, pl. 1, fig. 3 (non pl. 1, figs 1, 2, 5). 


\section{Diagnosis}

Schuchertoceras with gibbous mature conch with slightly depressed cross section, a basal septum and one ascocerid septum, a highly convex septum of truncation and a mature body chamber height of ca. $40 \mathrm{~mm}$.
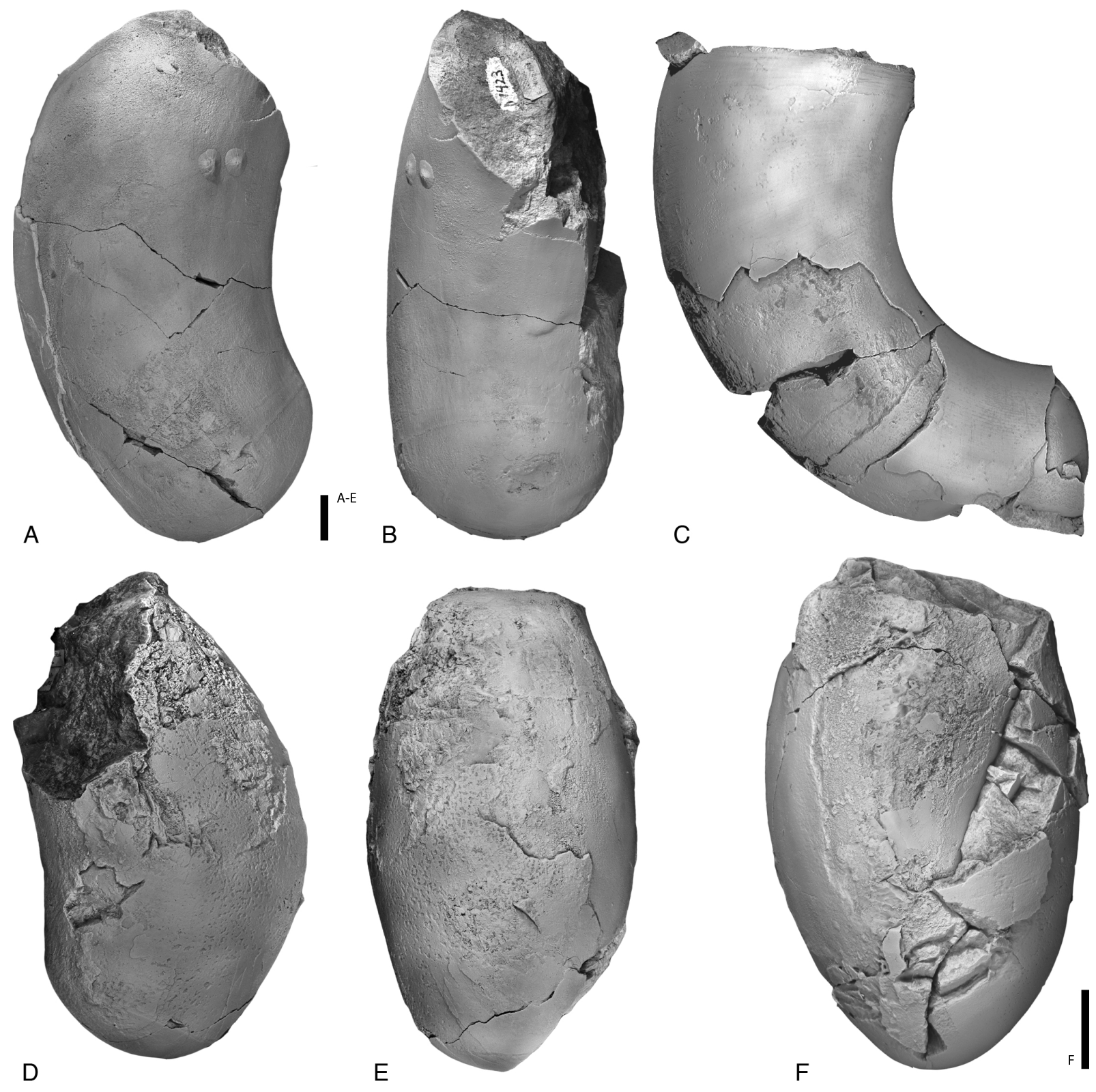

Fig. 39. Ascocerida and Uranoceratidae of the Boda Limestone. A-B. Redpathoceras bullatum sp. nov. A. PMU 26923, holotype, Kallholn; mature truncated body chamber, lateral view. B. Same specimen, view from antispihuncular side. C. Warburgoceras longitudinale (Angelin in Angelin \& Lindström, 1880) comb. nov., NRM-PZ Mo 154065, Unskarsheden; mature body chamber and part of phragmocone in lateral view. D-E. Probillingsites scandinavicum sp. nov., PMU 26922, holotype, Kallholn. D. Mature truncated body chamber, lateral view. E. Same specimen, view from prosiphuncular side. F. Schuchertoceras fryi sp. nov., PMU 24744, holotype, Kalllholn, lateral view. Scale bars: A-E =10 mm; $\mathrm{F}=10 \mathrm{~mm}$. 


\section{Etymology}

Refers to Mark W. Frye, who first described some of the ascocerids of the Boda Limestone (Frye 1982).

\section{Holotype}

PMU 24744.

\section{Type locality and horizon}

Kallholn, Dalarna, Sweden, Boda Limestone, Boda Core Member, late Katian, Ordovician.

\section{Description}

The specimen is a complete fragment of a mature conch. The outer shell is partially preserved and nearly smooth with fine, irregularly spaced growth lines. The total conch length is $65 \mathrm{~mm}$ and the maximum height of $40 \mathrm{~mm}$ and width of $44 \mathrm{~mm}$ (ratio width/height 1.1) are reached at approximately mid-length of the mature body chamber (Fig. 39F). The length/height ratio of the mature conch is 0.61 . The aperture is depressed, elliptical in cross section, with a height of $32 \mathrm{~mm}$ and a width of ca. $36 \mathrm{~mm}$. The septum of truncation is highly convex and dome-shaped, with a height of ca. $14 \mathrm{~mm}$ and oblique. The septal perforation is close to the conch margin (ca. $5 \mathrm{~mm}$ ). The ascocerid septum forms a short and pointed lobe and a wide and shallow sinus and almost reaches the aperture on the antisiphuncular side of the conch. The prosiphuncular side is slightly flattened in cross section (Fig. 10F).

\section{Remarks}

This specimen was assigned to Schuchertoceras troedssoni Frye, 1982 by Frye (1982: 1280) and described as an "unusually gibbous, and nearly egg-like" specimen. A reinvestigation of the specimens described by Frye (1982) reveals that PMU d727 is not only significantly larger than the other specimens assigned to $S$. troedssoni, which have a mature length of 40-50 $\mathrm{mm}$ only, but differs in having a highly convex septum of truncation. This is in strong contrast to the type of $S$. troedssoni, which possesses a relatively shallow and flat septum of truncation and which is clearly less gibbous in general conch form. These differences are considered to be significant here and justify the erection of a new species for this specimen.

\section{Stratigraphic and geographic range}

Boda Limestone, late Katian, Dalarna, Sweden.

Family Probillingsitidae Flower, 1941

Genus Probillingsites Foerste, 1928

\section{Type species}

Probillingsites welleri Foerste, 1928, Wisconsin, USA; probably Galena Dolomite, early-mid Katian, Ordovician; by original designation.

\section{Emended diagnosis}

Cyrtocones with truncated conch; mature conch inflated, higher than long or height similar to length; conch cross section circular to depressed; mature sutures generally oblique and slightly sinuous or sigmoid, but not lacunose; septal necks in latest septa strongly recumbent, cyrtochoanitic, in earlier septa suborthocoanitic; siphuncular segments expanded. 


\section{Remarks}

The morphology of Probillingsites scandinavicum sp. nov. indicates that the concept of Probillingsites requires adjustment as it is transitional between Redpathoceras and typical Probillingsites. In fact, the distinction between Redpathoceras and Probillingsites must be drawn relatively arbitrarily at the tenuous border between a mature body chamber characterized as "strongly inflated" (Probillingsites) or "inflated" (Redpathoceras), or between a mature truncated conch that is "obese" (Probillingsites) or breviconic (Redpathoceras). The ratio of the height/length of the mature conch may be used as a quantitative measure to distinguish between the two genera. In Redpathoceras clarki Flower, 1963, the type of Redpathoceras, this ratio is 0.48 and in $R$. magum sp. nov. and R. bullatum it is 0.46 ; in typical Probillingsites the height is greater than or equal to the length. In P. scandinavicum sp. nov. this ratio is 0.52 . Consequently, here Probillingsites is restricted to Probillingsitidae with conch heights that are greater than or equal to the mature conch length.

\section{Probillingsites scandinavicum sp. nov. urn:1sid:zoobank.org:act:42510E86-B2FE-40F7-8ED5-319BD939BDD4}

Fig. 39D-E

\section{Diagnosis}

Probillingsites with a smooth mature conch with depressed conch cross section; conch margins in longitudinal view convex on prosiphuncular side and concave on antisiphuncular side; maximum conch height of ca. $55 \mathrm{~mm}$ at mid-length of body chamber; septa of mature conch slightly oblique; sutures nearly straight.

\section{Etymology}

Refers to the larger type area; this is only the second species of Probillingsites known from the region.

\section{Holotype}

PMU 26922.

\section{Type locality and horizon}

Kallholn, Dalarna, Sweden, Boda Limestone, Boda Core Member, late Katian, Ordovician.

\section{Description}

The specimen is a nearly complete fragment of a mature conch, with a length of ca. $105 \mathrm{~mm}$. The height of the septum of truncation is $39 \mathrm{~mm}$ and the apertural height is ca. $40 \mathrm{~mm}$. The maximum height of $55 \mathrm{~mm}$ of the conch is approximately at mid-length of the body chamber, where the width is 59 $\mathrm{mm}$ (width/height ratio 1.07) (Fig. 39D, F). In cross-section the prosiphuncular side is more rounded, the prosiphuncular side slightly flattened. The aperture is constricted and depressed with an elliptical cross-section. The conch surface is poorly preserved but appears to be ornamented with fine, irregularly spaced growth lines.

The phragmocone is ca. $35 \mathrm{~mm}$ long and consists of four chambers. The septa are simple convex and slightly oblique, projecting toward the aperture on the antisiphuncular side. The septum of truncation is relatively shallow with a depth of ca. $6 \mathrm{~mm}$.

\section{Comparison}

This species is unique amongst the known species of Probillingsites in having only simple straight septa in the mature conch, a relatively long body chamber and a shallow convex septum of truncation. 


\section{Stratigraphic and geographic range}

Boda Limestone, late Katian, Dalarna, Sweden.

Genus Redpathoceras Flower, 1963

\section{Type species}

Redpathoceras clarki Flower, 1963, northeast of Joliette, Quebec, Canada; Leray Limestone, early-mid Katian, Ordovician; by original designation.

\section{Diagnosis}

Gyrocones with circular to depressed mature conch cross section; mature body chamber inflated with greatest diameter at approximate mid-length; broad shallow hyponomic sinus; septum of truncation deeply rounded; suture of septa in mature specimen slightly oblique, sloping in adoral direction on concave side of conch curvature; siphuncle eccentric, close to conch margin at convex side of conch curvature. (Adopted from Flower 1963.)

\section{Remarks}

Redpathoceras was assigned to the Probillingsitidae by Flower (1963) because of its deeply rounded septum of truncation and its inflated mature body chamber. The type species, Redpathoceras clarki, is characterized by a mature shell with only two chambers adoral of the terminal truncation; this is similar to Probillingsites. Some specimens of Redpathoceras from the Boda Limestone have mature truncated shells with five chambers (Redpathoceras magnus sp. nov.); this is very similar to Montyoceras Flower, 1941, and supports Flower's (1963) hypothesis of an ancestry of Billingsites and other ascocerids from a Montyoceras-like form. (The truncated parts of premature Redpathoceras phragmocones consist of ca. seven to eight chambers.)

On the other hand, the strongly curved conch portions of Redpathoceras are very similar to some uranoceratids, such as Deckeroceras Foerste, 1935, Siljanoceras gen. nov. and Warburgoceras gen. nov., from which it mainly differs in having a deeply convex septum of truncation. This suggests a relationship of Uranoceratidae with ascocerids (see discussion below).

The shape of the septal necks and connecting ring of the species of Redpathoceras known from the Boda Limestone are similar to those of Probillingsites (compare with Furnish \& Glenister 1964a: fig. 189.4; Fig. 40A-C). The connecting ring is slightly expanded in juvenile chambers and nummoidal and strongly expanded in the latest chambers. The septal necks are suborthochoanitic in juvenile stages and distally thickened and achoanitic in the latest stages.

\section{Stratigraphic and geographic range}

Leray Limestone, early-mid Katian, Quebec, Canada; Boda Limestone, late Katian, Dalarna, Sweden.

$$
\begin{aligned}
& \text { Redpathoceras bullatum sp. nov. } \\
& \text { urn:1sid:zoobank.org:act:B2601C0D-00FD-4084-B303-E0A0CB27E4A3 }
\end{aligned}
$$

Figs 10G, 39A-B, 40, 41, 42

\section{Diagnosis}

Redpathoceras with curved mature body chamber, inflated in lateral view with maximum height of ca. $60 \mathrm{~mm}$ at mid-length of body chamber; in longitudinal section mature body chamber conch margin at concave side of growth axis concave throughout total length; conch cross section compressed to circular in earlier growth stages; premature conch expands at $15^{\circ}$; diameter of terminal septum of truncation ca. 
$45 \mathrm{~mm}$; ornamented with fine longitudinal striae and irregularly spaced transverse growth lines, which form a wide hyponomic sinus.

\section{Etymology}

From Latin bullatus, sausage, referring to the form of the mature conch of this species.

\section{Type material}

\section{Holotype}

\section{PMU 26923.}

\section{Paratypes}

Three paratypes (PMU 26924-26926), Kallholn, Dalarna, Sweden, Boda Limestone, Boda Core Member, late Katian.

\section{Type locality and horizon}

Kallholn, Dalarna, Sweden, Boda Limestone, Boda Core Member, late Katian, Ordovician.

\section{Description}

The holotype is an incomplete internal mould of a mature body chamber with partly recrystallised shell fragments attached (Figs 10G, 39A-B). The septum of truncation and parts of the phragmocone are not preserved in the holotype. The base of the body chamber is $51 \mathrm{~mm}$ high and $49 \mathrm{~mm}$ wide (height/width ratio 1.04). The dimensions of the aperture are not preserved, but its total length is estimated at ca. 105 $\mathrm{mm}$. The body chamber reaches its greatest height of $60 \mathrm{~mm}$ at mid-length. The conch margin at the concave side of the conch curvature is curved throughout the total length of the body chamber.

The shell surface is nearly smooth with irregularly spaced growth lines, which form a broad shallow sinus on the convex side of the conch curvature. Traces of longitudinal striae are visible in parts of the surface.
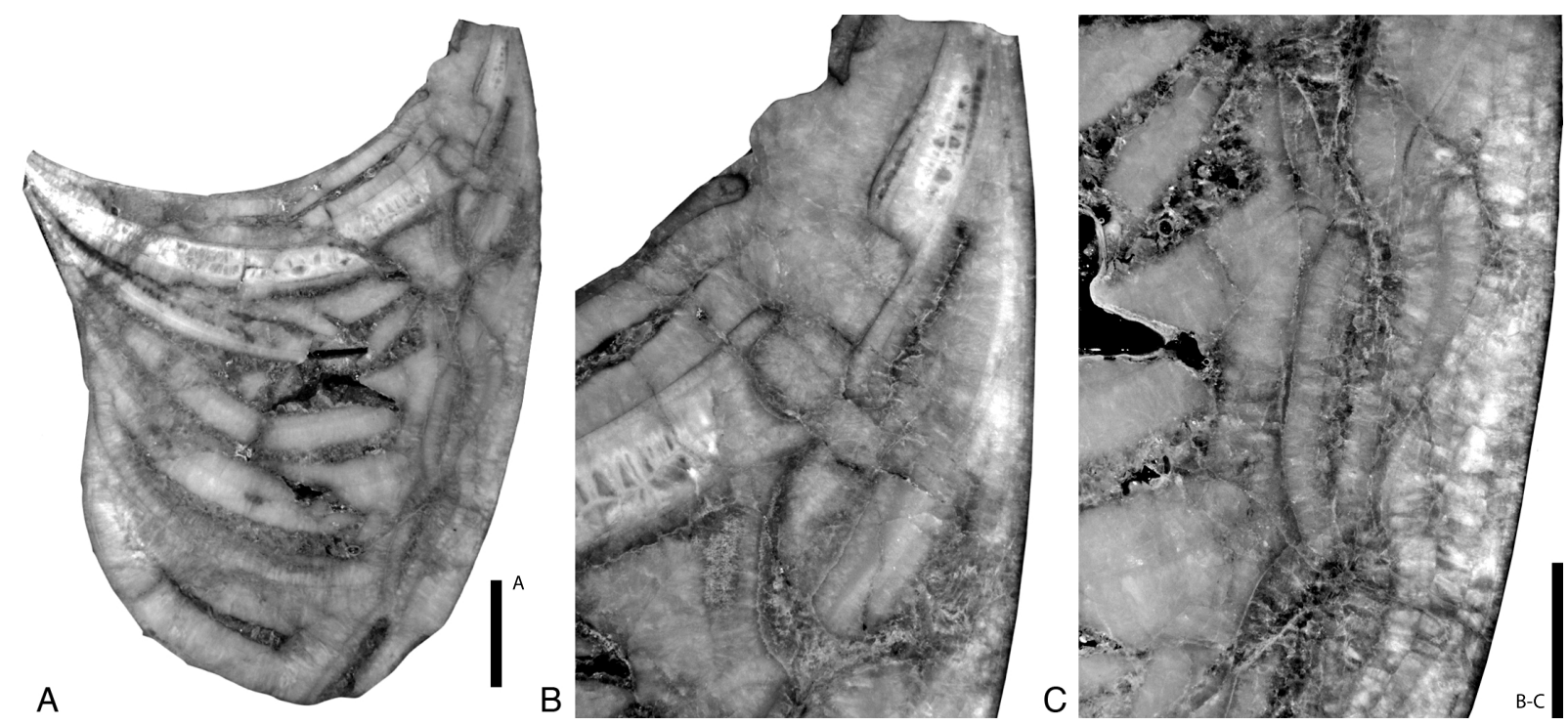

Fig. 40. Polished median section of Redpathoceras bullatum sp. nov., PMU 26926, Kallholn, Boda Limestone. A. Complete truncated phragmocone fragment. B. Adoral part with crowded septa and expanded siphuncular segments. C. Adapical part with wide septald distance and elongated siphuncular segments. Scale bars: A $=10 \mathrm{~mm}$; B-C $=5 \mathrm{~mm}$. 
The siphuncular perforation measures $5 \mathrm{~mm}$ (ca. 0.1 of conch height) and is positioned ca. $7 \mathrm{~mm}$ from the conch margin on the convex side of the conch curvature. The shell is ca. $1 \mathrm{~mm}$ thick at mid-length of the body chamber.

Specimen PMU 26926 is a complete, truncated portion of the phragmocone with a length at growth axis of ca. $40 \mathrm{~mm}$ and a conch height increasing from 33 to $44 \mathrm{~mm}$ (angle of expansion $15.4^{\circ}$ ) (Figs $40,41)$. The shell surface is well preserved and exhibits a fine longitudinal striation. The distance of the longitudinal striae varies between 0.5 and $1 \mathrm{~mm}$. Another specimen, representing the truncated part of a phragmocone (NRM Mo 152774), is $60 \mathrm{~mm}$ long and increases from 31 to $45 \mathrm{~mm}$ in height, and consists of eight chambers.

PMU 26926 (Fig. 40) comprises seven chambers with successively decreasing depth and convexity in the direction of growth. The depth of the apical-most chamber is $8 \mathrm{~mm}$, and its septa are deeply convex. By contrast, the adoral-most chamber is only $4 \mathrm{~mm}$ deep, with only a very shallow, convex septa. The septal perforation is positioned ca. $7 \mathrm{~mm}$ from the conch margin at the adoral-most septum. The septal necks are very unusual in being distally thickened, with the connecting rings forming an adnate attachment in the three crowded adoral-most septa. The septal necks associated with the remaining septa are suborthochoanitic. The connecting ring is thin and expanded between the chambers. The expansion of the siphuncular segments is highest in the adoral-most chambers.
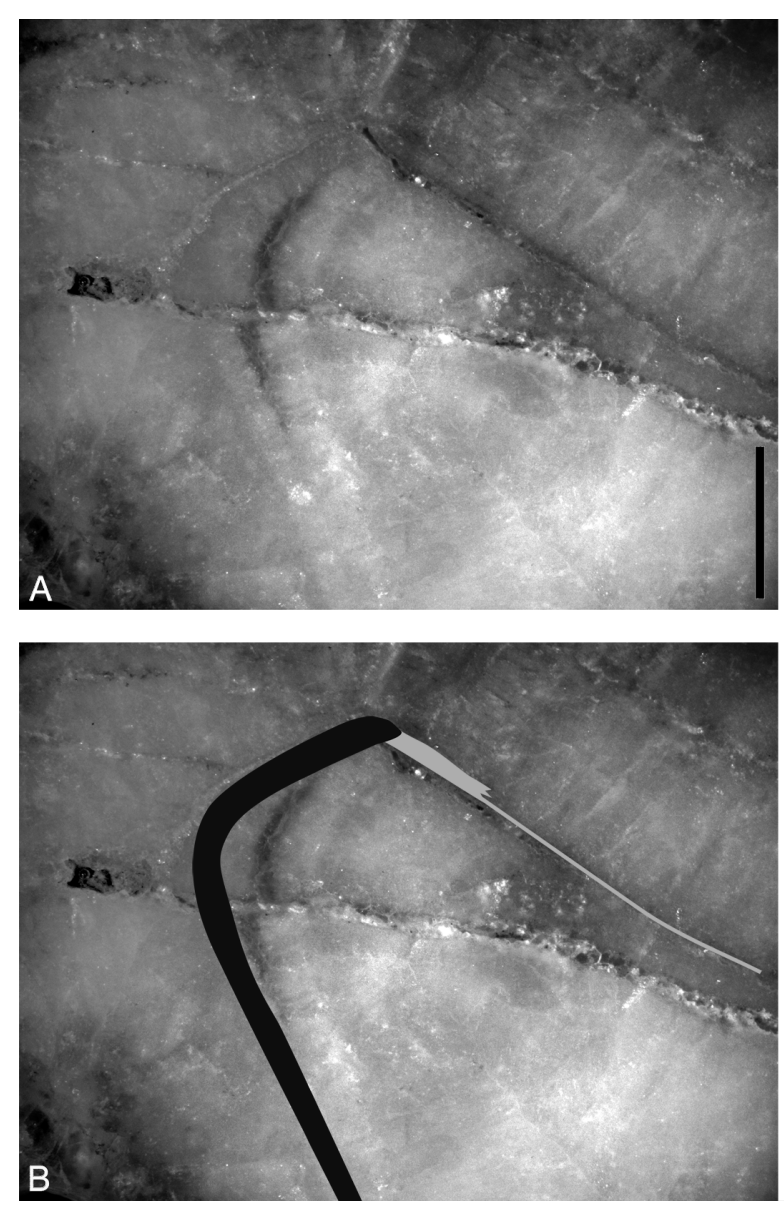

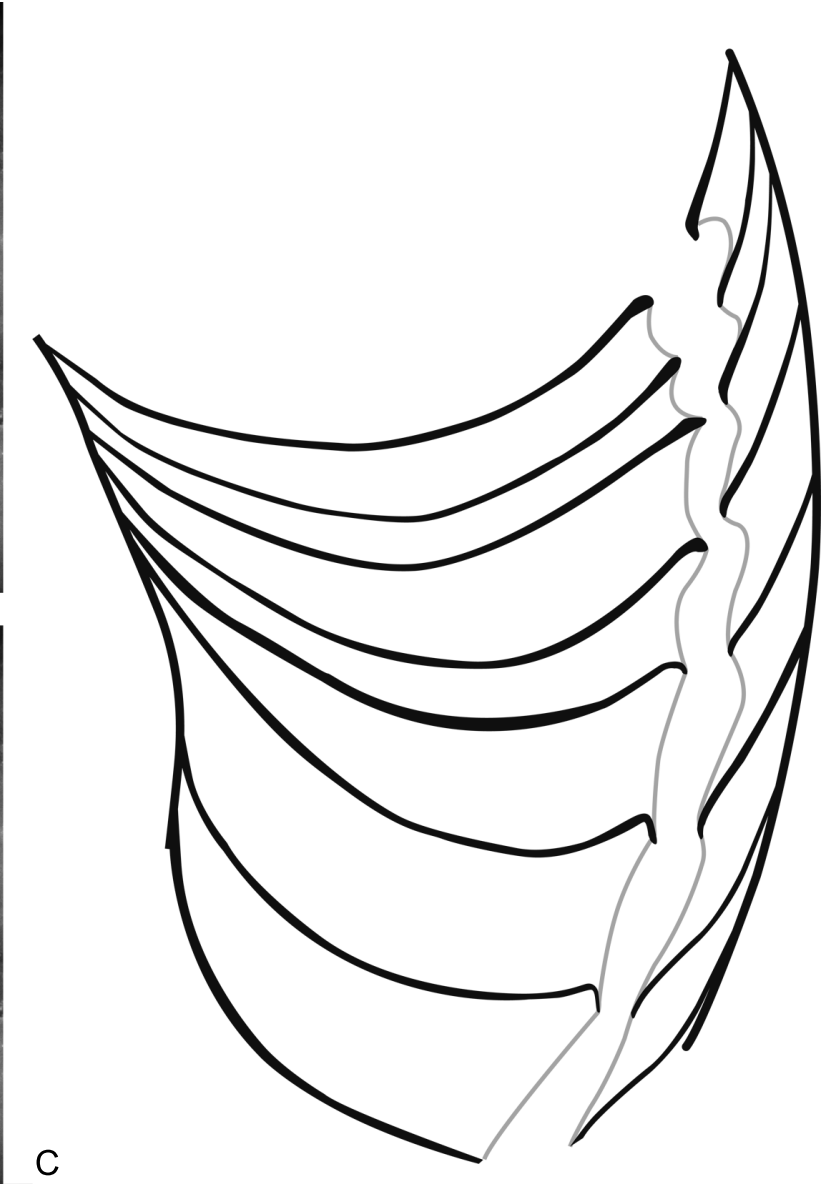

C

Fig. 41. Redpathoceras bullatum sp. nov., PMU 26926, Kallholn, Boda Limestone. A. Polished median section of detail of the septal neck and connecting ring. B. Reconstruction of A. C. Reconstruction of the total truncated fragment. Scale bar: A-B $=1 \mathrm{~mm}$. 


\section{Comparison}

This species of Redpathoceras differs from R. magnum sp. nov. in having a smaller mature conch of maximum height of $60 \mathrm{~mm}$ (Fig. 42), and in being entirely curved in lateral view on both the convex and concave side of the conch curvature. $R$. bullatum sp. nov. is larger than the type of the genus and has a less compressed conch cross section.

\section{Stratigraphic and geographic range}

Boda Limestone, late Katian, Dalarna, Sweden.

Redpathoceras depressum sp. nov.

urn:lsid:zoobank.org:act:C6767BCC-4FD2-4A7E-BE5C-F4738889A43E

Figs 10E, 18G, 42, 43D-F

\section{Diagnosis}

Redpathoceras with curved mature body chamber; inflated in lateral view with maximum height of ca. $55 \mathrm{~mm}$ at mid-length of body chamber; mature body chamber margin at concave side of conch curvature concave throughout total length; conch cross section depressed; premature conch expands with angle of expansion less than $10^{\circ}$; diameter of terminal septum of truncation ca. $45 \mathrm{~mm}$; ornamented with fine longitudinal striae and irregularly spaced transverse growth lines, which form a wide hyponomic sinus.

\section{Etymology}

Refers to the distinctively depressed conch cross section of this species.

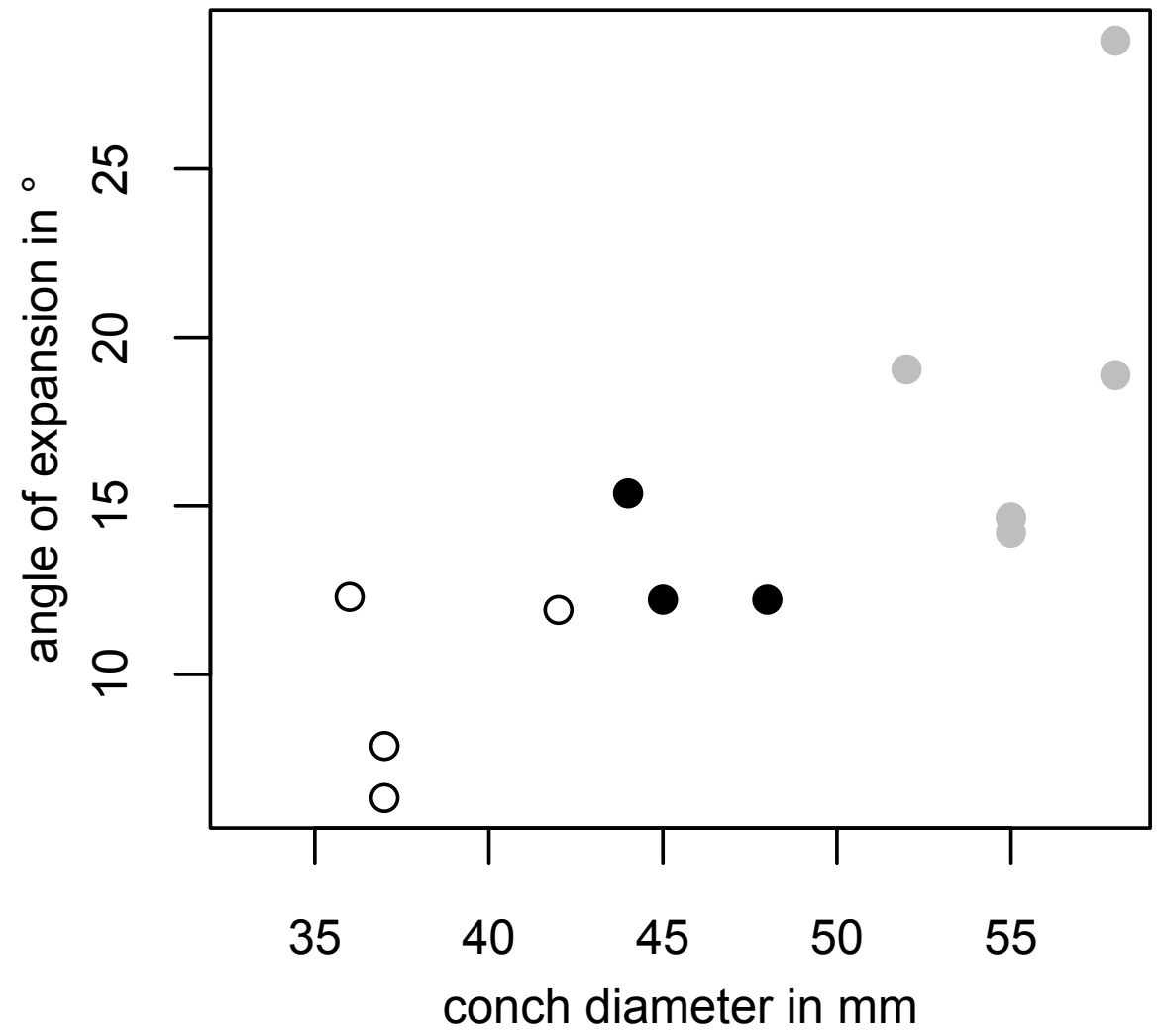

Fig. 42. Variation in angle of expansion in Redpathoceras Flower, 1963, Boda Limestone. R. magnum sp. nov. (grey dots); R. bullatum sp. nov. (black dots); R. depressum sp. nov. (black circles). 


\section{Type material}

Holotype

PMU 26927.

Paratypes

Seven paratypes (PMU 26928-26934), Kallholn, Dalarna, Sweden, Boda Limestone, late Katian.

\section{Type locality and horizon}

Kallholn, Dalarna, Sweden, Boda Limestone, Boda Core Member, late Katian, Ordovician.

\section{Description}

The holotype is a nearly complete mature conch, $120 \mathrm{~mm}$ long. The conch is depressed with a height of $41 \mathrm{~mm}$ and width of $48 \mathrm{~mm}$ at the septum of truncation (width/height ratio 1.2). At the aperture, these measurements are $50 \mathrm{~mm}$ and ca. $65 \mathrm{~mm}$, respectively (width/height ratio 1.3; Figs 10E, 43D, F). The mature conch is moderately curved. The convex side of the conch curvature is more strongly curved than the concave side, resulting in a maximum conch height at approximately the mid-length of the mature body chamber of $55 \mathrm{~mm}$. Immediately adoral to the septum of truncation the conch appears to be a slighty constricted. The length of the phragmocone and the numbers of chambers of the phragmocone are not known, as the conch wall obscures details of the septa. The outermost layer of the shell is poorly preserved, with no traces of the ornamentation remaining (Fig. 18G).

Four specimens (PMU 26930-26933) represent truncated portions of the phragmocone. All four specimens possess at their apical end a deeply curved septum of truncation. The conch height at the septum of truncation varies between 23 and $28 \mathrm{~mm}$ and the adoral-most diameters lie between 36 and $38 \mathrm{~mm}$, giving angles of expansion ranging from 6 to $8^{\circ}$ (Fig. 42). The conch cross section in these specimens is depressed (width/heigh ratio 1.03-1.16) and they are more curved than the mature fragment (holotype). In specimen NRM Mo 152301 the entire length comprises seven chambers. The suture is nearly directly transverse, but forms a shallow, wide lobe on the convex side of the conch curvature. All four specimens are distinctively ornamented with fine longitudinal striae and fine, irregularly spaced growth lines, forming a wide sinus on the convex side of the conch curvature.

\section{Comparison}

This species of Redpathoceras is similar to the type of the genus in having a depressed conch cross section, but differs in having a larger adult size. The adult size is similar to that seen in $R$. bullatum sp. nov., which in turn differs in having a circular-compressed conch cross section in premature growth stages.

\section{Stratigraphic and geographic range}

Boda Limestone, late Katian, Dalarna, Sweden.

Redpathoceras magnum sp. nov. urn:1sid:zoobank.org:act:5B495FBE-A8DE-4886-ABF4-FB22AC2D588F Figs 42, 43A-C

\section{Diagnosis}

Mature body chamber with slightly depressed cross section, moderately curved with maximum curvature close to aperture; inflated in lateral view with maximum height of ca. $70-80 \mathrm{~mm}$ at mid-length of body chamber; mature body chamber margin at concave side of conch curvature nearly straight on adapical two-thirds; conch cross section compressed to circular in earlier growth stages; premature conch expands with angle of expansion $15^{\circ}$; mature conch with ca. five phragmocone chambers adoral of the 

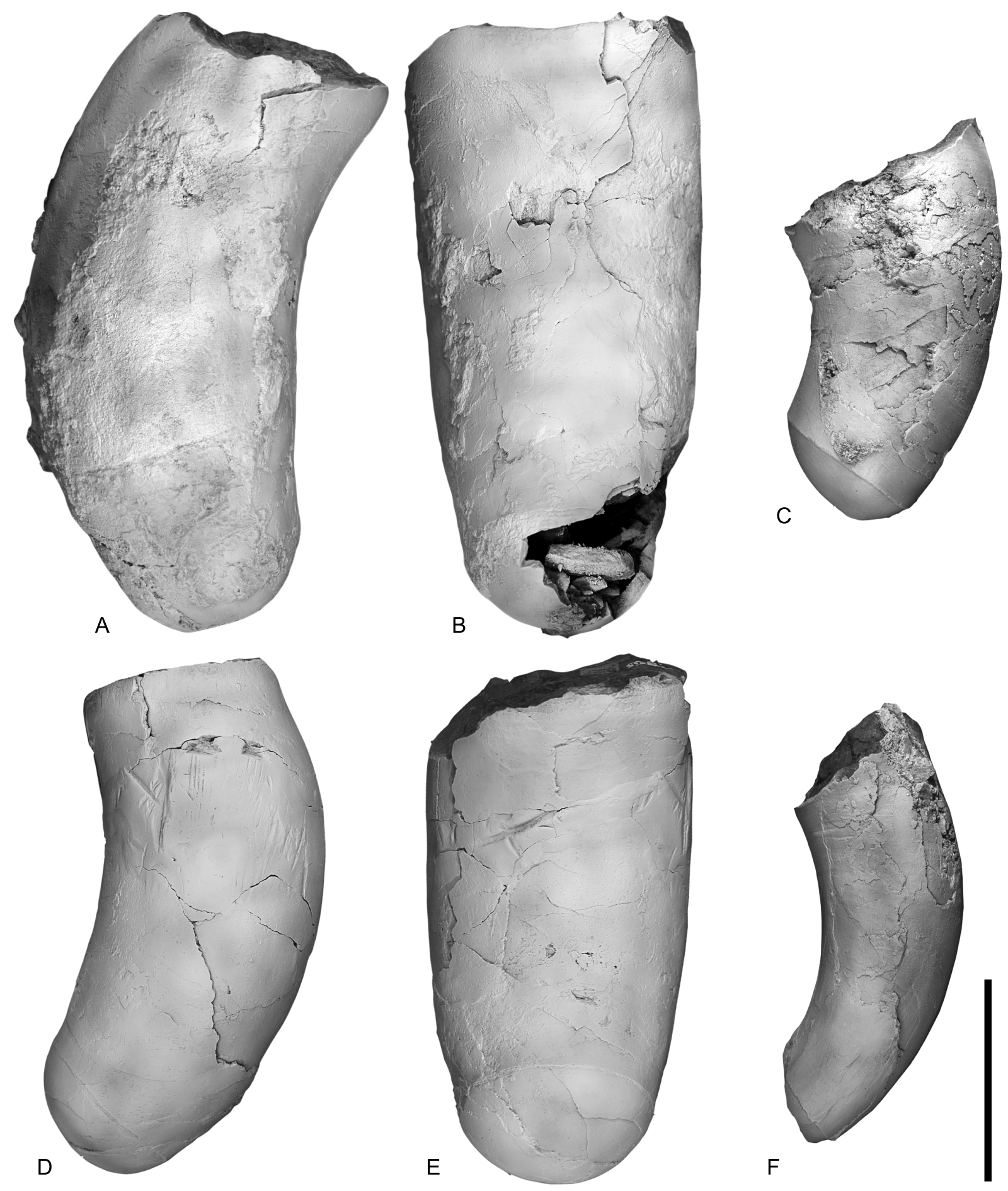

Fig. 43. Redpathoceras Flower, 1963, Kallholn, Boda Limestone. A-C. Redpathoceras magnum sp. nov. A. PMU 26935, holotype; mature truncated body chamber, lateral view. B. Same specimen, view from antispihuncular side. C. PMU 26946, premature truncated phragmocone, lateral view. D-F. Redpathoceras depressum sp. nov. D. PMU 26927, holotype; mature truncated body chamber, lateral view. E. Same specimen, view from antispihuncular side. F. PMU 26931, premature truncated phragmocone, lateral view. Scale bar $=50 \mathrm{~mm}$ for all figures. 
terminal septum of truncation; diameter of terminal septum of truncation ca. $55 \mathrm{~mm}$; ornamented with fine longitudinal striae and irregularly spaced transverse growth lines, which form a wide hyponomic sinus.

\section{Etymology}

Latin magnus refers to the large adult size of this species.

\section{Type material}

\section{Holotype}

\section{PMU 26935.}

\section{Paratypes}

Fourteen paratypes (PMU 26936-26948), Kallholn, Dalarna, Sweden, Boda Limestone, late Katian.

\section{Type locality and horizon}

Kallholn, Dalarna, Sweden, Boda Limestone, Boda Core Member, late Katian, Ordovician.

\section{Description}

The holotype is a fragment of a mature shell with a nearly complete body chamber combined with a phragocone consisting of five chambers (Fig. 43A-B). The maximum width of the body chamber is ca. $70 \mathrm{~mm}$, the maximum height $68 \mathrm{~mm}$ at a position approximately at body chamber mid-length (width/ height ratio 1.03). The complete length of the body chamber is ca. $100 \mathrm{~mm}$. The width of the bodychamber at the aperture is $70 \mathrm{~mm}$ and its height $63 \mathrm{~mm}$ (width/height ratio 1.11), at the base of the body chamber the width is $58 \mathrm{~mm}$ and the height $60 \mathrm{~mm}$ (width/height ratio 0.97). The body chamber is moderately curved, with a narrower curvature in adapertural sections.

The cross section of the aperture is slightly depressed with a more rounded margin on the convex side of conch curvature. The shell is thickened at the aperture with a thickness of ca. $2.5 \mathrm{~mm}$, compared with a thickness of $1.3 \mathrm{~mm}$ at body chamber mid-length. The surface of the shell is poorly preserved but apparently smooth.

The phragmocone has a length of $40 \mathrm{~mm}$ and expands with an angle of $19^{\circ}$. The four adoral chambers are shallow with a depth 0.15 that of the corresponding conch height; their septa are simple and cap shaped, with a shallow convexity, whilst the sutures are directly transverse, but slightly oblique and projecting toward the aperture on the concave side of the shell.

The septum of truncation is deeply convex, its depth is such that it is almost equal to the depth of the next two chambers. The siphuncular perforation is narrow, with a diameter of ca. $3 \mathrm{~mm}$ (ca. 0.07 of corresponding conch height) and positioned eccentrically at a distance of $8 \mathrm{~mm}$ from conch margin on convex side of conch curvature (SPR 0.18).

PMU 26942 is the largest fragment assigned to this species. It is a fragment of a body chamber with a maximum width of $78 \mathrm{~mm}$ and a maximum height of $70 \mathrm{~mm}$ (width/height ratio 1.11). The length of the body chamber is $100 \mathrm{~mm}$. The shell surface is ornamented with faint, irregularly spaced rounded striae or growth lines which form a broad, shallow hyponomic sinus on the convex side of the shell curvature.

In well preserved fragments of earlier growth stages with conch heights of less than $50 \mathrm{~mm}$, the shell surface is ornamented with irregularly, ca. $0.5-1 \mathrm{~mm}$ distant longitudinal striae and irregularly spaced growth lines that form a wide u-shaped hyponomic sinus on the convex margin of the shell (Fig. 43C). 


\section{Remarks}

Five specimens (PMU 26945-26947; NRM Mo 8795, 152300) are interpreted as truncated parts of the phragmocone (see, e.g., Fig. 43C). All five specimens possess at their apical end a deeply curved septum of truncation. Specimens NRM Mo 8795 and 152300 possess seven and eight chambers, respectively. The conch height at the septum of truncation varies between 36 and $45 \mathrm{~mm}$ and the adoralmost diameters are $55 \mathrm{~mm}$, resulting in angles of expansion of $14-15^{\circ}$ (Fig. 42). The conch cross section in these specimens is slightly compressed to circular and they are more curved longitudinally than the mature fragments. The suture is nearly directly transverse, but forms a shallow, wide lobe on the convex side of the conch curvature. The assignment of these fragments to R. magnum sp. nov. is justified by their similar conch cross section and by the sizes of their adoral-most septa, which agree well with the size of the septum of truncation of the mature stage of the holotype.

Based on the fragments of different growth stages a conch can be reconstructed, that, if it had not been truncated at several stages, would possess an angle of expansion of ca. $15^{\circ}$ in juvenile growth stages, a rate of expansion of more than $20^{\circ}$ at the adoral end of the phragmocone and a decreasing height during its final growth stages. The inflation of the body chamber is a result of a nearly straight outline of the shell margin at the antisiphuncular side of the conch during the initial stages of growth of the mature body chamber.

\section{Comparison}

This is a large species of Redpathoceras, its mature conch width being more than twice that of the type species. It differs from the type species in having a conch cross section which changes during growth from compressed to depressed. $R$. bullatum sp. nov. differs in having a smaller adult size and a less inflated mature body chamber, with a concave outline of the conch margin on the concave side of the conch curvature. In $R$. magnum sp. nov. the outline of the mature body chamber at the antisiphuncular side is nearly straight in the apical two-thirds.

\section{Stratigraphic and geographic range}

Boda Limestone, late Katian, Dalarna, Sweden.

Family Hebetoceratidae Flower, 1941

Genus Parvihebetoceras Kröger, 2007

\section{Type species}

Parvihebetoceras wahli Kröger, 2007, from the Porkuni Formation, Hirnantian, Porkuni, Estonia, by monotypy.

\section{Diagnosis}

Small longiconic orthocones with slightly depressed or circular cross section; truncated adult shell nearly tubular with few, closely spaced, shallow concave septa possessing straight, directly transverse sutures; conch surface smooth or ornamented with faint growth lines; septum of truncation occurs at a conch diameter of about four to five millimeters; adult cross section diameter approximately seven millimeters; siphuncular diameter approximately one-tenth of conch diameter; siphuncle positioned between centre of conch and conch margin; siphuncular diaphragm present slightly adorally of the septum of truncation; septal necks are asymmetric, more elongated at ventral side, achoanitic and suborthochoanitic in juvenile growth stages, suborthochoanitic in adult growth stages; apex bullet-shaped, slightly cyrtoconic, cicatrix present, with diameter at first septum approximately $1.4 \mathrm{~mm}$; no endosiphuncular deposits are known. (Adopted from Kröger 2007.) 
Parvihebetoceras wahli Kröger, 2007

Fig. 44

Parvihebetoceras wahli Kröger, 2007: 599, figs 4c, 7c, 9.

\section{Diagnosis}

Same as for genus, by monotypy.

\section{Type locality and horizon}

Porkuni, Estonia, Porkuni Formation, Hirnantian, Ordovician.
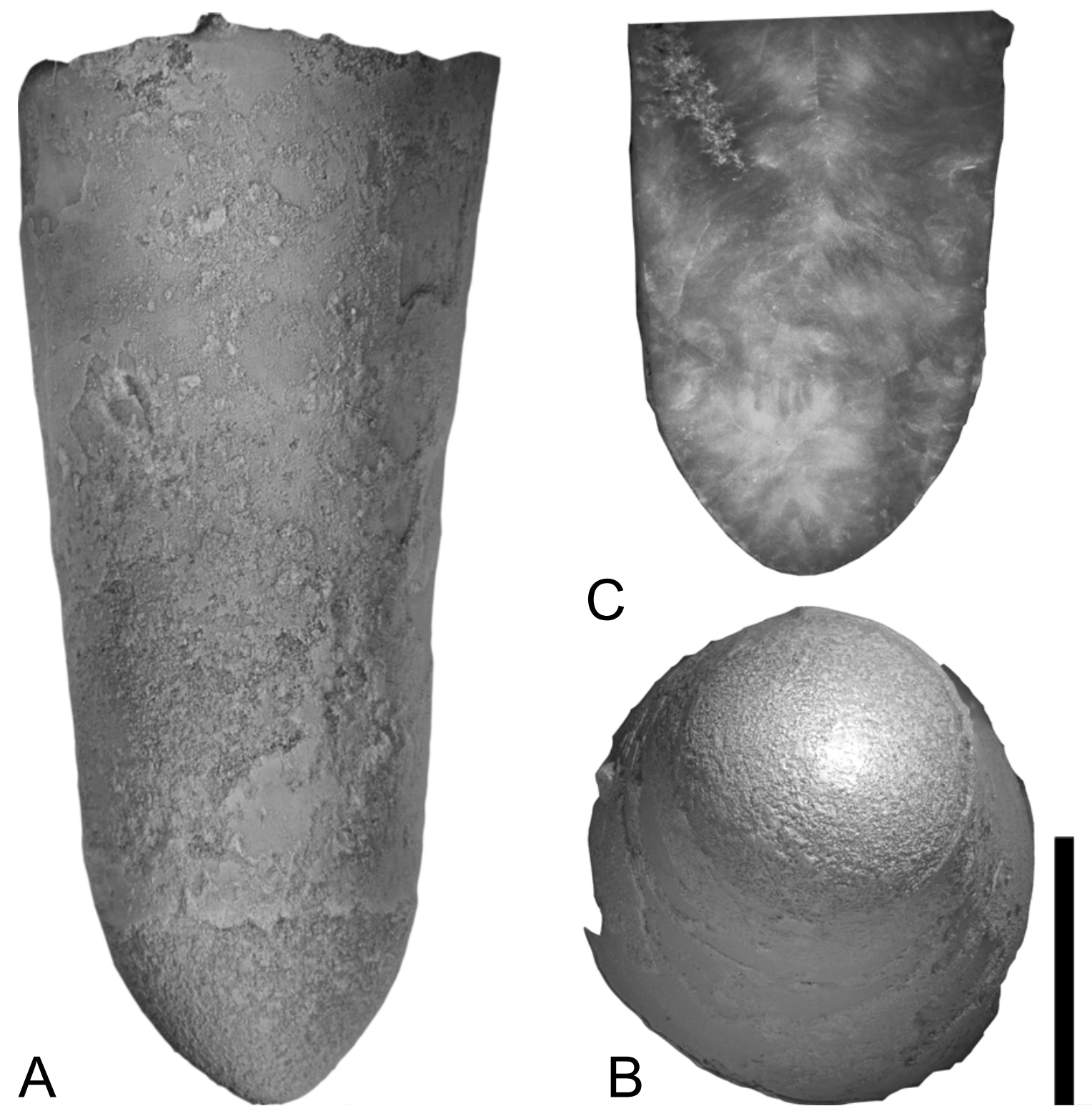

Fig. 44. Parvihebetoceras wahli Kröger, 2007, PMU 26949, Kallholn, Boda Limestone. A. Lateral view. B. Adapical view. C. Median section with one septum preserved. Scale bar $=5 \mathrm{~mm}$ for all figures. 


\section{Material}

One specimen (PMU 26949), Kallholn, Dalarna, Sweden, Boda Limestone, Boda Core Member, late Katian, Ordovician.

\section{Description}

The specimen is a fragment of a body chamber with one apical chamber of the phragmocone (Fig. 44). The conch is slightly curved, the cross section circular, 5.4-8.3 $\mathrm{mm}$ in diameter and $16 \mathrm{~mm}$ long (angle of expansion $10^{\circ}$ ). The shell surface is partly preserved and smooth. Apically the conch is truncated with a dome-shaped, deeply convex septum of truncation. The adapical surface of the septum of truncation is rugged. The convexity of the septum is $3.5 \mathrm{~mm}$. The tip of the septal dome is slightly subcentral, off the center of the conch in direction toward the convex side of the conch curvature. A second septum is preserved, ca. $4 \mathrm{~mm}$ adorally of the septum of truncation, which is less convex and with a subcentral septal perforation (Fig. 44C). The shape of the septal neck is poorly preserved, but probably was achoanitic or very short suborthochoanitic; it appears longer on the prosiphuncular side of the conch. Parts of the connecting ring are preserved, which indicate a slightly expanded siphuncular segment. Because of the poor preservation of the internal details, the presence or absence of cameral deposits is difficult to evaluate, but thin hyposeptal deposits appear to be present at the adoral septum (Fig. 44C) and the rugged surface of the septum of truncation may be interpreted as the surface of episeptal deposits.

\section{Remarks}

The deeply convex, dome-shaped septum of truncation, the shape of the septal necks and the position and shape of the siphuncle are diagnostic characters of Parvihebetoceras. The conch size of the Boda specimen is identical to that of Parvihebetoceras wahli Kröger, 2007 from the Porkuni Formation of northern Estonia. P. wahli reaches its adult size with a diameter of ca. $7 \mathrm{~mm}$ and has a septum of truncation at diameters of ca. $5 \mathrm{~mm}$. Because of the general similarity of the Boda specimen with the Estonian specimens described in Kröger (2007), it is regarded as conspecific with P. wahli. However, the Estonian specimens of $P$. wahli appear slightly more brevidomic and have slightly smaller adult sizes.

The specimen described herein shows features that can be interpreted as hyposeptal deposits on the adoral septum. However, because of the poor preservation of the internal characters, it is impossible to evaluate if these are primary or secondary deposits. Therefore, they are not included within the diagnosis of the species.

The rough, poorly preserved surface of the septum of truncation is similar to that in the middle Silurian Sphooceras Flower, 1962, but in Sphooceras the shape of the septal necks and siphuncle differ and heavy cameral deposits are developed, which are absent in Parvihebetoceras.

Order, family, genus and species indet. A

Figs 4D, 18A

\section{Material}

Specimen PMU 26950, Kallholn, Siljan District, Sweden; Boda Limestone, Boda Core Member, late Katian, Late Ordovician.

\section{Description}

The specimen is a nearly complete fragment of a body chamber $110 \mathrm{~mm}$ long; parts of the basal septum are preserved, as are parts of the aperture (Fig. 4D). The conch is slightly curved and increases from ca. 55 to $75 \mathrm{~mm}$ in height and is $50 \mathrm{~mm}$ wide at the base (angle of expansion 13 ${ }^{\circ}$, width/height ratio 
0.91). The conch opens gradually. The conch cross section is subrectangular with lateral flanks and antiand prosiphuncular surfaces. The position and shape of the siphuncle cannot be determined. The shell is ornamented with distinctive transverse annuli, which are slightly irregularly spaced (distance ca. 3-5 $\mathrm{mm}$ ) and form a broad shallow sinus on the convex side of the conch curvature (Fig. 18A). Additionally, a number of 8-10 crenulated and frilled lirae run parallel to the annulations within the distance of one cycle of annulations. On the inner surface of the shell a distinctive wrinkle layer is preseverved

\section{Remarks}

Because no closely similar cephalopod conch is known from the Late Ordovician and no details of the position and the shape of the siphuncle is preserved, no determination, even at the ordinal level, is possible. The ornamentation and slight curvature of the shell might indicate an affinity with a member of the Dawsonoceratidae or Barrandeoceridae.

\section{Discussion}

\section{Remarks the evolution of the Ascocerida}

Several cephalopod species with truncated conchs occur in the Boda Limestone. These are morphologically transitional between typical ascocerids such as Billingsites Hyatt, 1884 and large gyroconic nontruncated forms such as Warburgoceras gen. nov., traditionally assigned to the Uranoceratidae. Within the Boda Limestone a nearly continuous morphological transition may be drawn between the untruncated curved Warburgoceras gen. nov., possessing a nearly tubular mature body chamber and the truncated Redpathoceras with its inflated mature body chamber. The strongly inflated body chamber of Probillingsites Foerste, 1928 and of Schuchertoceras Miller, 1932 has adventitious septa (Fig. 44). When comparing the Boda Limestone cephalopods, exclusively, an unambiguous reconstruction of the origin of the ascocerids may be hypothesised such that ascocerids originated from strongly curved forms related to Uranoceras Hyatt, 1884 and Warburgoceras gen. nov. (Fig. 44).

This contrasts with earlier hypotheses. Previously, only the juvenile conchs of Ascoceras Barrande, 1847 were known (e.g., Lindström 1890). In Ascoceras the juvenile conch is slender, orthocerid-like, and only slightly curved. Based probably on the detailed reconstructions of the Mid Silurian Ascoceras, Kesling (1961) reconstructed an orthocerid-like, slender and widely curved juvenile shell in Billingsites and Probillingsites. Generally, a slender, nearly orthoconic shell was considered to be a synapomorphy of the lineage Probillingsites-Ascoceras lineage (Flower 1941: fig. 1). The Mid Ordovician truncated orthocone Hebetoceras Flower, 1941 was considered central in this reconstruction.

Hebetoceras in turn was regarded as the hypothetical descendent of another Mid Ordovician truncated form described by Flower (1941), the relatively large and curved Montyoceras Flower, 1941. Montyoceras was considered the ancestral ascocerid (Flower 1941, 1963). In Flower's phylogenetic reconstructions, Montyoceras-like cyrtocones evolved into Hebetoceras-like orthoceracones that finally evolved into the highly specialized Ascoceras-like forms.

The occurrence of curved truncated forms in the Late Ordovician Boda Limestone suggests that Hebetoceras did not lie in the direct ancestry of the Ascoceras lineage. Instead, an early divergence must be assumed between slender orthoconic truncated forms and cyrtoconic truncated forms. The large and considerably curved Montyoceras titaniforme Flower, 1941 is much more similar to the Boda ascocerids than any orthocone.

Flower (1941: 543) had already emphasized that several Mid-Late Ordovician depressed cyrtocones existed, which were probably closely related to Montycoceras. The internal characters of most of these cyrtocones are poorly known. Within this group the truncated Katian Redpathoceras Flower, 1963, now 
known in greater detail from the Boda Limestone, represents one such genus. It is highly probable that the late Katian non-truncated Deckeroceras Foerste, 1935 from the Fernvale Formation of Oklahoma and Warburgoceras gen. nov. from the Boda Limestone are closely related to Redpathoecras and Montycoceras. This group of four genera is characterized by relatively large curved shells and, most likely, a fine longitudinal ornament (compare Figs $18 \mathrm{~F}$ and $18 \mathrm{G}$ ), as well as a ventrally, eccentrically positioned siphuncle with expanded siphuncular segments and achoanitic to suborthochoanitic septal necks with very thin connecting rings.

Warburgoceras longitudinale (Angelin in Angelin \& Lindström, 1880) comb. nov., the type of Warburgoceras gen. nov., is very similar to the truncated Redpathoceras. The curved shell, the ornamentation, the position and form of the siphuncle, and the short septal necks are nearly identical in both genera (compare Fig. 40 and Mutvei 1957: fig. 17.1). Earlier this species, which was described in great detail by Mutvei (1957), was assigned to Uranoceras Barrande, 1866 (Mutvei 1957; Dzik 1984). Here it is regarded as a distinct genus, mainly because of moderate differences in the shell outline (see below). Without doubt, both species are closely related and represent a relatively long ranging evolutionary lineage, the Uranoceratidae.

The affinities of this lineage were disputed. The Uranoceratidae were assigned to the Barrandeocerida by Sweet (1964a) and to the Centroceratina by Dzik (1984), but a close affinity with ascocerids was never proposed. The similarity between Warburgoceras gen. nov., Uranoceras, Redpathoceras, Probillingsites and Billingsites may be a coincidence, but a more parsimonious solution would be to assume a close phylogenetic relationship between these genera. Here, it is assumed that a group of non-truncated Uranoceras-like cyrtocones gave rise to the truncated Montycoceras/Redpathoceras-like forms, and the typical ascoceratids subsequently evolved from these forms. The uranoceratids and the ascocerids originated from the same group of Mid Ordovician non-truncated cyrtocones. The entire group of truncated and un-truncated cyrtocones is characterized by a ventrally, eccentrically positioned siphuncle, which is slightly expanded within the chambers and has a very thin connecting ring. The fine longitudinal ornamentation is probably also a synapomorphy for this group. Moreover, a similar very characteristic ventromyarian periphract is present in the uranoceratids Warburgoceras gen. nov., Siljanoceras gen. nov. and in the ascoceratid Billingsites (compare Mutvei 1957; Sweet 1959).

This assumption opens a new perspective, not only on the origin of the Ascoceratida, but also on the phylogenetic relationships of the Barrandeoceratidae. Formerly, the origin of the Ascoceratida was sought for in orthoconic forms such as Sactorthoceras (Flower 1941). The cyrtoconic and coiled Mid Ordovician Barrandeoceratidae and Aspidoceratidae were not even considered as potential ancestors or as being closely related to the Ascocerida. These two families were placed in the Barrandeocerida by Sweet (1964a), and in the Tarphycerida by Dzik (1984) and Flower (1984). Neither Dzik (1984) or Flower (1984) accepted the order Barrandeocerida, regarding the differences in the thickness of the connecting ring between typical Tarphyceratida and Barrandeocerida as insufficiently significant for the distinction of an order.

By contrast, Mutvei (2002) placed emphasis on the importance of the structure of the connecting ring for reconstructing the phylogenetic relationships of higher groups and distinguished between an Orthocerastype connecting ring and a Nautilus-type connecting ring. The Tarphycerida are characterized by a Nautilus-type connecting ring (Mutvei 2002; Mutvei \& Dunca 2011). The connecting ring of the the Late Silurian uranoceratid Cumingsoceras complanatus (Hisinger, 1831) was interpreted by Mutvei \& Dunca (2011) as being of the Orthoceras-type, which may be taken to indicate an affinity with the Orthocerida. Mutvei \& Dunca (2011) argued for an assignment of Cumingsoceras complanatus and the Uranoceratidae within the Barrandeocerida and considered the Orthoceras-type connecting ring as a diagnostic character of that order. The connecting ring of Redpathoceras in the Boda Limestone is 
only poorly preserved, but a median section (Fig. 40) reveals that it is thin, simple and resembles that of Cumingsoceras complanatus and Warburgoceras longitudinale comb. nov. At present, however, there is no positive evidence for a calcified perforated layer in Redpathoceras.

In the context of the phylogenetic scheme presented here (Fig. 45), the nature of the connecting ring might suggest that Ascocerida and Uranoceratidae were both descendants of the Orthocerida. This concurs with the earlier hypothesis of Flower (1941) of an orthocerid ancestor of the Ascocerida.

It is, however, in conflict with the observations of Mutvei (2012) regarding the structure of the connecting ring of Choanoceras Lindström, 1890. Choanoceras is a Mid Silurian ascocerid, which is considered as representing an early offshoot of the Montyoceras-Hebetoceras-Billingsites lineage by Furnish \& Glenister (1964a) and Dzik (1984). Mutvei (2012) interpreted the structure of the siphuncle of Choanoceras as being of the Nautilus-type and questioned the idea of an orthocerid origin of the Ascocerida. Instead, he found a greater similaritiy of Choanoceras to the Discosorida in terms of the structure of the connecting ring and suggested a close ascocerid-discosorid relationship.

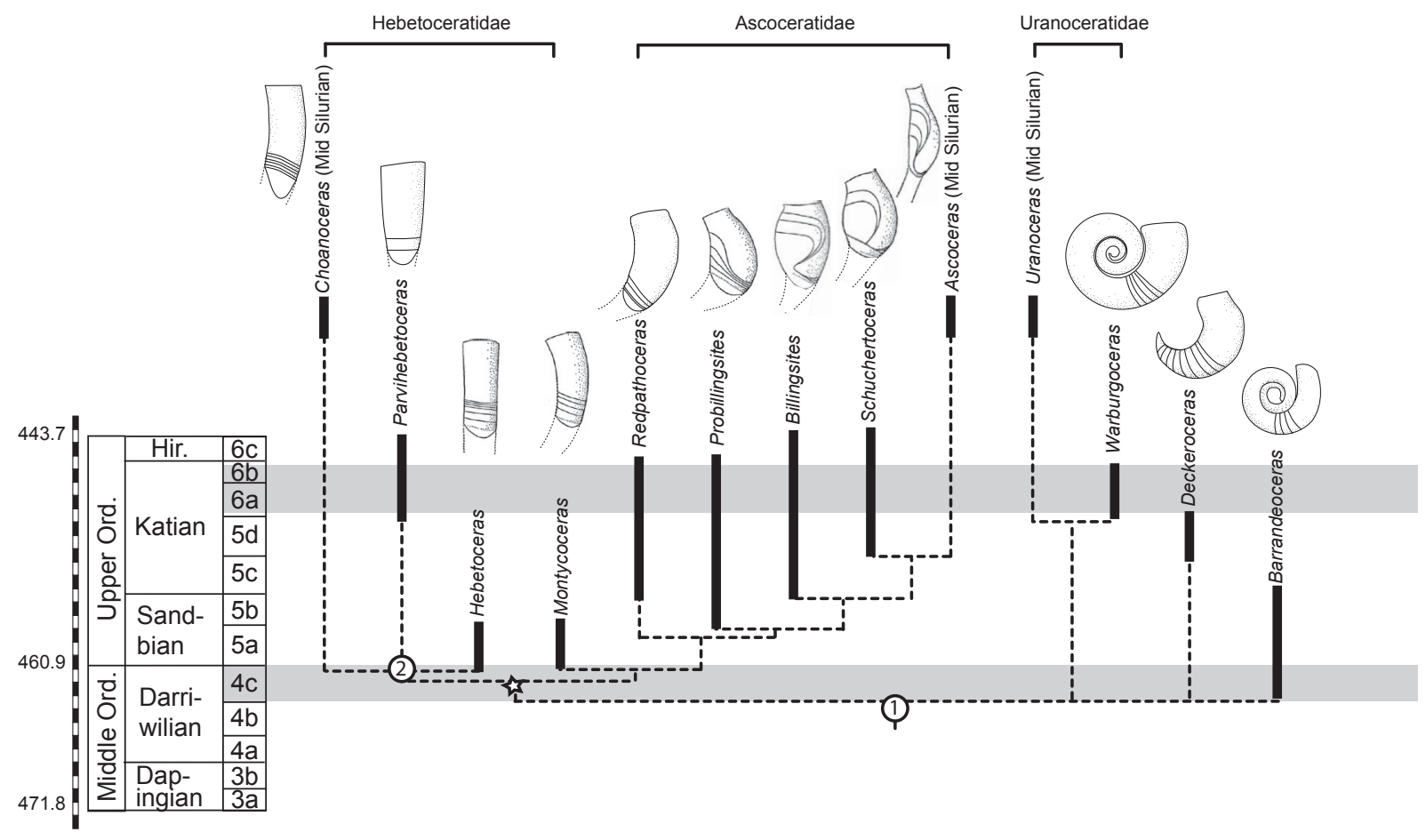

Fig. 45. Hypothesis about the phylogenetic relationship of selected Ascocerida and Barrandeocerida. Note the phylogenetic trend of decoiling in ascocerids. The diversification of ascocerids occurred during the late Mid Ordovician. Star = truncation; $1=$ thin subcentral siphuncle with orthocerid-like thin connecting ring; 2 = uncoiling. The close phylogenetic relationship between the uranoceratid Warburgoceras gen. nov. and ascocerids is based on the general similarity of shell shape, ornamentation, sipho-position and connecting ring shape of Redpathoceras Flower, 1963. Note also that Montyoceras titaniforme Flower, 1941 is larger, more rapidly expanding and more strongly coiled than the type of the genus, and thus much more similar to Redpathoceras. Figures of Hebetoceras Flower, 1941; Montycoceras Flower, 1941; Probillingsites Flower, 1941; Billingsites Hyatt, 1884; Schuchertoceras Miller, 1932; and Ascoceras Barrande, 1847 are modified from Kesling (1961). Figures of Choanoceras Lindström, 1890 are based on Furnish \& Glenister (1964a); those of Deckeroceras Foerste, 1935 and Barrandeoceras Flower, 1950 are based on Sweet (1964a). 
If Mutvei's (2012) and Mutvei \& Dunca's (2011) conclusions are correct and the connecting ring of Choanoceras is of the Nautilus-type and Redpathoceras and Cumingsoceras are of the Orthocerastype, the Ascocerida and the evolution of truncation must be regarded as polyphyletic. This seems very improbable, as all other characters suggest a close affinity between the straight and curved ascocerids and the Uranoceratidae.

Specifically, the position of the siphuncle (near convex conch margin in ascocerids/uranoceratids, near concave margin in discosorids), the shape of the periphract (ventromyarian in ascocerids/uranoceratids, with multiple attachment scars in discosorids/oncocerids, see Sweet 1959) and the features of the connecting ring (thin and simple, probably of Orthoceras-type, and empty in premature ascocerids/ uranoceratids, thick and often with endosiphuncular deposits in discosorids and oncocerids) speak against a close ascocerid-discosorid relationship.

The preservation of the Silurian forms described by Mutvei \& Dunca (2011) is rather imperfect and the illustrated structures could also be interpreted as very thin connecting rings of the Nautilus-type (this is especially the case for the figures 1a-c, and 1f of Mutvei \& Dunca 2011) with a non-preserved inner organic fibrous layer. There is no positive evidence for a calcified perforated layer in the figured specimen and the black layer of Mutvei \& Dunca (2011) could be interpreted as a diagenetically altered and expanded spherulitic prismatic layer. Similarily, the connecting ring structures of Choanoceras figured in Mutvei (2012) are imperfectly preserved, and the bulletes, figured in Mutvei (2012: fig. 8a, b) could alternatively be interpreted as an effect of the plane in which the specimen was cut, which appears to be oblique to the axis of the siphuncle.

In conclusion, the new data from the Boda Limestone indicates that ascocerid ancestors were cyrtocones possessing eccentric, slightly expanded siphuncles with thin connecting rings and short septal necks. These ancestors most probably belong to the Mid Ordovician Barrandeoceratidae or Aspidoceratidae. The structure of the connecting ring of the Ascocerida is still poorly known and largely subject to interpretation. Inconsistencies in current hypotheses of the evolution of the Ascocerida result from incomplete knowledge of the connecting ring structure of the group of coiled and curved Mid-Late Ordovician cephalopods that were assigned within the Barrandeocerida by Sweet (1964a). Future research needs to focus on the analysis of the structure of the connecting ring of these forms.

\section{Conclusions}

The taxonomic revision of the cephalopods in the museum collections of the NRM and the PMU reveals the presence of 62 species, across 32 genera, comprising cephalopods of the orders Ascocerida, Barrandeocerida, Discosorida, Endocerida, Oncocerida, Orthocerida and Tarphycerida (Tables 2, 3). Of these, three genera and 16 species are new. Additionally, the revision led to a number of new combinations (Table 4).

The number of cephalopod genera known from the Boda Limestone is almost equal to that of the bivalves (34, see Isberg 1934) and is larger than the number of strophomenid brachiopod genera (25, see Cocks 2005). Bearing in mind that cephalopods were among the top predators of the Boda reef ecosystem, their high diversity indicates an extremely rich fauna of organisms lower in the food chain. Indeed, extremely high Boda trilobite diversities were reported, and very high gastropod diversities have been estimated by Ebbestad \& Högström (2007). However, the main food resources of the Boda cephalopods are probably not preserved. Crustaceans, which have a poor preservation potential (Plotnick 1986), are the main component in the diet of modern cephalopods (Glynn \& Enochs 2011). The most common and the most diverse Boda cephalopods are orthocerids (Table 3), which are interpreted as vertical migrants in the water column (Westermann 1998; Kröger et al. 2009). Therefore, a cephalopod feeding within the water column is likely (Kröger et al. 2009). This could be interpreted as indirect evidence for a high 
Table 2. Number of specimens in the collections of the NRM and PMU from the most important Boda Limestone localities. Note that sample sizes are not always identical with number of specimens examined and described in the text, because not all specimens in the collections of the NRM have been examined in detail. (A\&L = Angelin \& Lindström)

\begin{tabular}{|c|c|c|c|c|c|c|c|}
\hline & $\begin{array}{c}\text { species } \\
\text { nr }\end{array}$ & Kallholn & $\begin{array}{c}\text { Osmunds- } \\
\text { berget }\end{array}$ & $\begin{array}{c}\text { Unskars- } \\
\text { heden }\end{array}$ & Rättvik & $\begin{array}{c}\text { Skål- } \\
\text { berget }\end{array}$ & $\begin{array}{r}\text { Ost- } \\
\text { björka }\end{array}$ \\
\hline Beloitoceras siljanense Frye, 1987 & 1 & 14 & 1 & 0 & 0 & 0 & 0 \\
\hline Beloitoceras sinuososeptatum (Roemer, 1861) & 2 & 13 & 0 & 0 & 0 & 1 & 0 \\
\hline Beloitoceras sp. & - & 2 & 0 & 0 & 0 & 0 & 0 \\
\hline Bodoceras torticoni Frye, 1982 & 3 & 6 & 0 & 0 & 0 & 0 & 0 \\
\hline Cameroceras regulus (Eichwald, 1860) & 4 & 0 & 0 & 0 & 0 & 0 & 1 \\
\hline Cameroceras hasta (Eichwald, 1857) & 5 & 4 & 0 & 0 & 0 & 0 & 0 \\
\hline Cameroceras turrisoides sp. nov. & 6 & 8 & 3 & 5 & 0 & 0 & 0 \\
\hline Charactoceras kallholnense Frye, 1982 & 7 & 21 & 0 & 1 & 0 & 0 & 0 \\
\hline Charactoceras raettvikense Frye, 1982 & 8 & 1 & 0 & 0 & 1 & 0 & 0 \\
\hline Charactoceras suecicum Frye, 1982 & 9 & 1 & 0 & 0 & 0 & 0 & 0 \\
\hline Charactoceras triangulum Frye, 1982 & 10 & 2 & 1 & 0 & 0 & 0 & 0 \\
\hline Cyrtorizoceras thorslundi sp. nov. & 11 & 10 & 1 & 0 & 0 & 0 & 0 \\
\hline Dalecarlioceras bodense Frye, 1987 & 12 & 1 & 0 & 0 & 0 & 0 & 0 \\
\hline Dalecarlioceras constrictum Frye, 1987 & 13 & 1 & 0 & 0 & 0 & 0 & 0 \\
\hline Dalecarlioceras dalecarlicum (Frye, 1987) & 14 & 3 & 0 & 0 & 1 & 0 & 0 \\
\hline Danoceras broeggeri (Strand, 1934) & 15 & 1 & 0 & 0 & 0 & 0 & 0 \\
\hline Danoceras scandinavicum (Strand, 1934) & 16 & 3 & 0 & 0 & 0 & 0 & 0 \\
\hline Dawsonoceras fenestratum (Eichwald, 1860) & 17 & 15 & 2 & 0 & 0 & 0 & 0 \\
\hline Dawsonoceras stumburi sp. nov. & 18 & 2 & 0 & 0 & 0 & 0 & 0 \\
\hline Dowlingoceras kallholnense Frye, 1987 & 19 & 3 & 0 & 0 & 0 & 0 & 0 \\
\hline Diestoceras parallelum Frye, 1987 & 20 & 2 & 0 & 0 & 0 & 0 & 0 \\
\hline Discoceras antiquissimum (Eichwald, 1842) & 21 & 1 & 0 & 0 & 0 & 0 & 0 \\
\hline Discoceras roemeri Strand, 1934 & 22 & 4 & 0 & 0 & 0 & 1 & 0 \\
\hline Geisonoceras wegelini (Angelin in A\&L, 1880) & 23 & 5 & 0 & 19 & 0 & 0 & 3 \\
\hline Geisonoceras sp. A & 24 & 1 & 0 & 0 & 0 & 0 & 0 \\
\hline Gorbyoceras alternestriatum (Strand, 1934) & 25 & 3 & 0 & 1 & 0 & 0 & 0 \\
\hline Gorbyoceras sp. A & 26 & 0 & 1 & 0 & 0 & 0 & 0 \\
\hline Gorbyoceras sp. B & 27 & 1 & 0 & 0 & 0 & 0 & 0 \\
\hline Parvihebetoceras wahli Kröger, 2007 & 28 & 1 & 0 & 0 & 0 & 0 & 0 \\
\hline Isorthoceras angelini sp. nov. & 29 & 13 & 0 & 0 & 0 & 0 & 0 \\
\hline Isorthoceras curvilineatum sp. nov. & 30 & 0 & 3 & 0 & 0 & 0 & 0 \\
\hline Isorthoceras dalecarlense Kröger et al., 2011 & 31 & 19 & 0 & 0 & 0 & 0 & 0 \\
\hline Isorthoceras cf. elongatocinctum (Portlock, 1843) & 32 & 20 & 1 & 0 & 0 & 0 & 0 \\
\hline Isorthoceras heroyense (Strand, 1934) & 33 & 4 & 0 & 0 & 0 & 0 & 0 \\
\hline Isorthoceras junceum (Hall, 1847) & 34 & 3 & 0 & 0 & 0 & 0 & 0 \\
\hline Isorthoceras leptaenarum (Angelin in A\&L, 1880) & 35 & 0 & 0 & 0 & 0 & 0 & 1 \\
\hline Isorthoceras suave (Angelin in $\mathrm{A} \& \mathrm{~L}, \mathbf{1 8 8 0}$ ) & 36 & 4 & 3 & 1 & 0 & 0 & 2 \\
\hline Isorthoceras wahlenbergi Niko, 2008 & 37 & 79 & 1 & 4 & 0 & 0 & 0 \\
\hline Kallholnoceras cornutum Frye, 1987 & 38 & 3 & 0 & 0 & 0 & 0 & 0 \\
\hline Kiaeroceras heroyense Strand, 1934 & 39 & 1 & 0 & 0 & 0 & 0 & 0 \\
\hline
\end{tabular}


Table 2, continued.

\begin{tabular}{|c|c|c|c|c|c|c|c|}
\hline Nathorstoceras kallholnense sp. nov. & 40 & 5 & 0 & 0 & 0 & 0 & 0 \\
\hline Nathorstoceras adnatum sp. nov. & 41 & 1 & 0 & 0 & 0 & 0 & 0 \\
\hline Ordogeisonoceras foerstei (Strand, 1934) & 42 & 8 & 0 & 1 & 0 & 0 & 0 \\
\hline Palaeodawsonocerina senckenbergi (Teichert, 1930) & 43 & 7 & 2 & 0 & 0 & 0 & 0 \\
\hline Palaeodawsonocerina sp. A & 44 & 2 & 0 & 0 & 0 & 0 & 0 \\
\hline Palaeodawsonocerina? nicolletoides sp. nov. & 45 & 2 & 0 & 0 & 0 & 0 & 0 \\
\hline Pleurorthoceras osmundsbergense sp. nov. & 46 & 1 & 45 & 0 & 0 & 0 & 0 \\
\hline Probillingsites scandinavicum sp. nov. & 47 & 1 & 0 & 0 & 0 & 0 & 0 \\
\hline Redpathoceras bullatum sp. nov. & 48 & 5 & 0 & 0 & 0 & 0 & 0 \\
\hline Redpathoceras depressum sp. nov. & 49 & 7 & 0 & 0 & 0 & 0 & 0 \\
\hline Redpathoceras magnum sp. nov. & 50 & 19 & 0 & 0 & 0 & 0 & 0 \\
\hline Redpathoceras sp. & - & 1 & 0 & 0 & 0 & 0 & 0 \\
\hline Schuchertoceras bodense Frye, 1982 & 51 & 6 & 0 & 0 & 0 & 0 & 0 \\
\hline Schuchertoceras fryi sp. nov. & 52 & 1 & 0 & 0 & 0 & 0 & 0 \\
\hline Schuchertoceras troedssoni (Foerste, 1929) & 53 & 4 & 0 & 1 & 0 & 0 & 0 \\
\hline Siljanoceras varians sp. nov. & 54 & 10 & 0 & 0 & 0 & 0 & 0 \\
\hline Siljanoceras sp. A & 55 & 1 & 0 & 0 & 0 & 0 & 0 \\
\hline Strandoceras sphinx (Schmidt, 1858) & 56 & 3 & 0 & 0 & 0 & 0 & 0 \\
\hline Striatocycloceras isbergi sp. nov. & 57 & 36 & 1 & 0 & 0 & 0 & 0 \\
\hline Striatocycloceras sp. & - & 1 & 0 & 0 & 0 & 0 & 0 \\
\hline Tyrioceras warburgae Frye, 1982 & 58 & 12 & 0 & 2 & 0 & 0 & 0 \\
\hline Tyrioceras kjaerulfi Strand, 1934 & 59 & 1 & 0 & 0 & 0 & 0 & 0 \\
\hline Warburgoceras longitudinale (Ang. in A\&L, 1880) & 60 & 17 & 4 & 2 & 0 & 0 & 0 \\
\hline Order, gen. et sp. indet 1 & 61 & 1 & 0 & 0 & 0 & 0 & 0 \\
\hline
\end{tabular}

abundance and diversity of nektonic and planktonic crustaceans in the Boda reef waters. High nutrient levels of the Boda reef waters are probably also indicated by the high abundance of suspension feeders, such as brachiopods (which is expressed in the old name "Leptaena Limestone" for the Boda Limestone; see, e.g., Cocks 2005), and byssate bivalves (Isberg 1934).

Despite the extraordinarily high cephalopod diversity (a detailed diversity analysis and comparison with contemporary assemblages is in preparation and will be published in a forthcoming paper by the author) and the relatively large number of observed specimens (more than 500), not a single actinocerid cephalopod has been recorded in the Boda Limestone. Actinocerids are abundant in contemporaneous cephalopod assemblages of low palaeolatitudes and in Late Ordovician reef settings and are present in contemporaneous assemblages of Norway and Estonia (Teichert 1930; Strand 1934; Kröger et al. 2009). This absence or extraordinary rarity is provisionally interpreted as evidence for a depositional environment in relatively deep waters or in relatively cold waters. However, a detailed faunal analysis which includes absolute depth measurements based on hydrostatic strength estimates of the cephalopod shells is required for a more substantiated interpretation, which is in preparation and will be published in a forthcoming paper. Moreover, a reliable diversity analysis can only be based on subsampled diversity estimates.

The taxonomic revision presented here clearly demonstrates the importance of cephalopods in the Boda reef ecosystem and their potential to contribute to a better understanding of the processes that led to the formation of the Boda reefs. 
Table 3. Systematic classification of cephalopods from the Boda Limestone, late Katian-Hirnantian, Dalarna, Sweden and sample size.

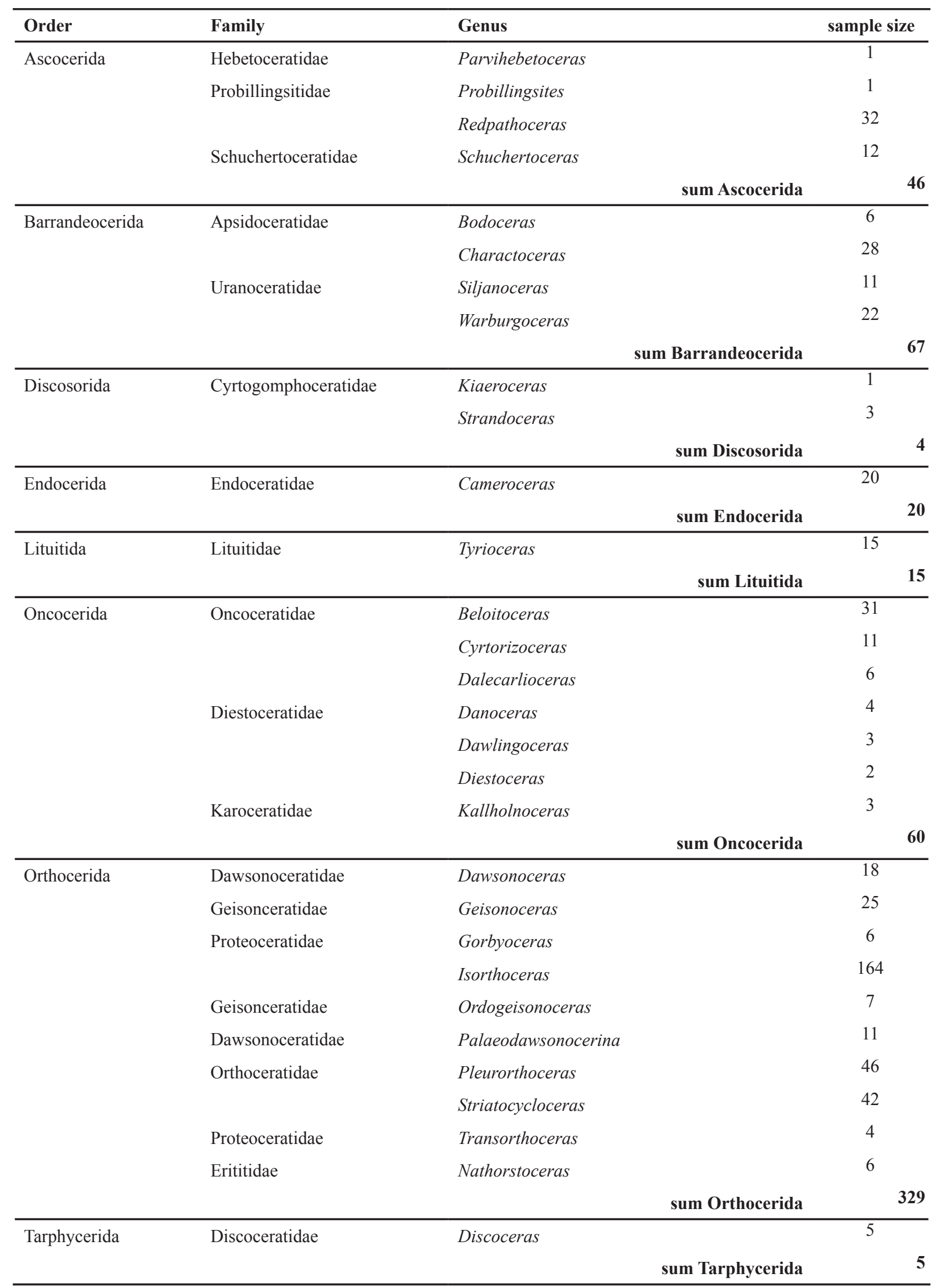


KRÖGER B., Cephalopods of the Boda Limestone

Table 4. List of new name combinations proposed in this paper. (A\&L = Angelin \& Lindström)

\begin{tabular}{ll}
\hline Original name & New combination, herein \\
\hline Cyrtorizoceras dalecarlicum Frye, 1987 & Dalacarlioceras dalecarlicum (Frye, 1987) \\
Cyrtoceras longitudinale Angelin in A\&L, 1880 & Warburgoceras longitudinale (Angelin in A\&L, 1880) \\
Endoceras akpatokense Foerste \& Cox, 1936 & Cameroceras akpatokense (Foerste \& Cox, 1936) \\
Endoceras coxi Foerste \& Cox, 1936 & Cameroceras coxi (Foerste \& Cox, 1936) \\
Endoceras windriverense Miller, 1932 & Cameroceras windriverense (Miller, 1932) \\
Geisonoceras foerstei Strand, 1934 & Ordogeisonoceras foerstei (Strand, 1934) \\
Geisonoceras heroyense Strand, 1934 & Isorthoceras heroyense (Strand, 1934) \\
Michelinoceras dnestrovense Balashov, 1975 & Isorthoceras dnestrovense (Balashov, 1975) \\
Monomuchites bacotense Balashov, 1975 & Nathorstoceras bacotense (Balashov, 1975) \\
Orthoceras elongato-cinctum Portlock, 1843 & Isorthoceras elongatocinctum (Portlock, 1843) \\
Orthoceras leptaenarum Angelin, in A\&L, 1880 & Isorthoceras? leptaenarum (Angelin in A\&L, 1880) \\
Orthoceras suave Angelin in A\&L, 1880 & Isorthoceras suave (Angelin in A\&L, 1880) \\
Orthoceras textumaraneum Roemer, 1861 & Gorbyoceras textumaraneum (Roemer, 1861) \\
Orthoceras wegelini Angelin, in A\&L, 1880 & Geisonoceras wegelini (Angelin in A\&L, 1880) \\
Spyroceras alternestriatum Strand, 1934 & Gorbyoceras alternestriatum (Strand, 1934) \\
\hline
\end{tabular}

\section{Acknowledgments}

This paper could not have been realised without the ongoing support and help of Jan Ove Ebbestad, Uppsala, Sweden. His engagement offered me the possibility to work several months at the PMU and to use and install the equipment needed for this work. Many thanks also to Stefan Bengtson of the NRM who granted me access to the paleozoological collections, and to Jonas Hagström of the NRM for his support during my visits in Stockholm. The discussions with Harry Mutvei, Stockholm inspired me to develop hypotheses about the origin of the Ascocerida. David Evans, Peterborough, UK and Kathleen Histon, Varese, Italy thoroughly reviewed an earlier draft of the manuscript, improved the English and with their comments helped to increase the quality of this work. I am grateful for their support.

\section{References}

Ainsaar L., Kaljo D., Martma T., Meidla T., Männik P., Nõlvak J. \& Tinn O. 2010. Middle and Upper Ordovician carbon isotope chemostratigraphy in Baltoscandia: A correlation standard and clues to environmental history. Palaeogeography, Palaeoclimatology, Palaeoecology 294 (3-4): 189-201. http:// dx.doi.org/10.1016/j.palaeo.2010.01.003

Angelin N.P. \& Lindström G. 1880. Fragmenta Silurica. Samson and Wallin, Stockholm.

Baily W.H. 1875. Figures of Characteristic British Fossils, Volume 1, Palaeozoic. Van Voorst, London.

Balashov E.G. 1953. Svernutye i polivernutye nautiloidei ordovika pribaltiki. Trudy Vsesoyuznogo Neftyanogo Nauchno-Issledovatel'skogo Geologo-Razvednoknogo Instituta 78: 217-268.

Balashov E.G. 1956. Nautiloidei ordovika Chu-Iliiskich gor i Vet-Chak-Daly. Trudy Geologicheskogo Instituta, Akademia Nauk SSSR 1: 196-200.

Balashov E.G. 1962. Nautiloidei Ordovika Sibirskoi Platformy. Izdatel'stvo Leningradskogo Universiteta, Leningrad.

Balashov E.G. 1968. Endoceratoidei Ordovika SSSR. IIzdatel'stvo Leningradskogo Universiteta, Leningrad.

Balashov E.G. 1974. Endoceratida. In: Ruzhentsev V.E. (ed.) Fundamentals of Paleontology, Vol. V, Mollusca - Cephalopoda I, Vol. V: 74-81. Smithsonian Institution Libraries Translations Program, Jerusalem. 
Balashov E.G. 1975. Cefalopody molodovskogo i kitayogorodskogo gorizontov Podolii. Voprosy Paleontologii 7: 63-101.

Bassler R.S. 1919. The Cambrian and Ordovician Deposits of Maryland. In: Bassler R.S. (ed.) Systematic Paleontology. Mollusca: 277-331. Maryland Geological Survey, Baltimore.

Bergström S.M. 2007. The Ordovician conodont biostratigraphy in the Siljan region, south-central Sweden: a brief review of an international reference standard. In: Ebbestad J-O.R., Wickström L.M. \& Högström E.S. (eds) 9th Meeting of the Working Group on Ordovician Geology of Baltoscandia, Field Guide and Abstracts. Sveriges Geologiska Undersökning, Rapporter och Meddelanden 128:26-41.

Bergström S.M., Chen X., Gutiérrez-Marco J.C. \& Dronov A. 2009. The new chronostratigraphic classification of the Ordovician System and its relation to major regional series and stages and to $\partial^{13} \mathrm{C}$ chemostratigraphy. Lethaia 42: 97-107. http://dx.doi.org/10.1111/j.1502-3931.2008.00136.x

Blake J.F.A. 1882. Monograph of the British Fossil Cephalopoda, Part 1, Introduction and Silurian species. John Van Voorst, London.

Catalani J.A. 1987. Biostratigraphy of the Middle and Upper Ordovician cephalopods of the Upper Mississippi Valley area. Minnesota Geological Survey Report of Investigations 35: 187-189.

Chen, J-Y. \& Zou X-P. 1984. Ordovician cephalopods from the Ordos area, China. Memoirs of the Nanjing Institute of Geology and Palaeontology 20: 33-111.

Cherns L. \& Wheeley J.R. 2007. A pre-Hirnantian (Late Ordovician) interval of global cooling - The Boda event re-assessed. Palaeogeography, Palaeoclimatology, Palaeoecology 251 (3-4): 449-460. http://dx.doi.org/10.1016/j.palaeo.2007.04.010

Cherns L. \& Wheeley J.R. 2009. Early Palaeozoic cooling events: peri-Gondwana and beyond. Geological Society, London, Special Publications 325 (1): 257-278. http://dx.doi.org/10.1144/SP325.13

Cocks L.R.M. 2005. Strophomenate brachiopods from the late Ordovician Boda Limestone of Sweden: Their systematics and implications for palaeogeography. Journal of Systematic Palaeontology J 3(3): 243-282. http://dx.doi.org/10.1017/S1477201905001616

Dzik J. 1984. Phylogeny of the Nautiloidea. Palaeontologia Polonica, Vol. 45, 203 pp.

Dzik J. \& Korn D. 1992. Devonian ancestors of Nautilus. Paläontologische Zeitschrift 66 (1): 81-98.

Ebbestad J-O.R. \& Högström A.E.S. 2007. Ordovician of the Siljan District, Sweden. WOGOGOB, 2007, 9th meeting of the Working Group on Ordovician Geology of Baltoscandia, Field Guide and Abstracts 128: 52-58.

Eichwald E. von. 1840. Über das silurische Schichtensystem in Esthland. Zeitschrift für Naturwissenschaften und Heilkunde der Akademie St. Petersburg 8: 1-327.

Eichwald E. de. 1842. Die Urwelt Russlands durch Abbildungen erlaeutert. 2. Heft. Neuer Beitrag zur Geognosie Esthlands und Finlands. Akademie der Wissenschaften, St. Petersburg.

Eichwald E. de. 1857. Beitrag zur geographischen Verbreitung der fossilen Thiere Russlands. Alte Periode. Bulletin de la Societé impériale des Naturalistes d'Histoire de Moscou 30: 192-212.

Eichwald E. de. 1860. Lethaea Rossica ou Paléontologie de la Russie. Schweizerbart, Stuttgart.

Evans D.H. 1993. The cephalopod fauna of the Killey Bridge Formation (Ordovician, Ashgill), Pomeroy, County Tyrone. Irish Journal of Earth Sciences 12: 155-189.

Evans D.H. 1994. The cephalopod fauna of the Bardahessaigh Formation (Caradoc Series) of Pomeroy, County Tyrone. Irish Journal of Earth Sciences 13: 11-29.

Evans D.H. 1996. Cephalopods. Palaeontological Association Field Guides to Fossils 7: 116-127. 
Evans D.H. 2002. Some additional Ordovician and Silurian cephalopods from Ireland. Special Papers in Palaeontology 67: 77-96.

Flower R.H. 1941. Development of the mixochoanites. Journal of Paleontology 15 (5): 523-548.

Flower R.H. 1946. Ordovician cephalopods from the Cincinnati region. Part 1. Bulletins of American Paleontology 26 (116): 3-547.

Flower R.H. 1962. Part 1, Revision of Buttsoceras. Part 2, Notes on the Michelinoceratida. State Bureau of Mines and Mineral Resources, New Mexico Institute of Mining and Technology, Memoir 10: 1-58.

Flower R.H. 1963. New Ordovician Ascoceratida. Journal of Paleontology 37 (1): 69-85.

Flower R.H. 1984. Bodeiceras, a New Mohawkian Oxycone, with Revision of the Older Barrandeoceratida and Discussion of the Status of the Order. Journal of Paleontology 58 (6): 1372-1379.

Flower R.H. \& Kummel B. 1950. A classification of the Nautiloidea. Journal of Paleontology 24: 604616.

Flower R.H. \& Teichert C. 1957. The cephalopod order Discosorida. University of Kansas Paleontological Contributions, Art. 21 (Mollusca, Art. 6): 1-144.

Foerste A.F. 1925. Notes on Cephalopod genera, chiefly coiled Silurian forms. Journal of the Scientific Laboratories of Denison University 21: 1-69.

Foerste A.F. 1928. A restudy of American orthoconic Silurian cephalopods. Journal of the Scientific Laboratories of Denison University 23: 236-320.

Foerste A.F. 1932. Black River and other cephalopods from Minnesota, Wisconsin, Michigan, and Ontario (Part 1). Journal of the Scientific Laboratories of Denison University 27: 47-136.

Frey R.C. 1995. Middle and Upper Ordovician Cephalopods of the Cincinnati Region of Kentucky, Indiana, and Ohio. United States Geological Survey Professional Paper 1066P: 1-119.

Frye M.W. 1982. Upper Ordovician (Harjuan) nautiloid cephalopods from the Boda Limestone of Sweden. Journal of Paleontology 56: 1274-1292.

Frye M.W. 1987. Upper Ordovocian (Harjuan) oncoceratid nautiloids from Boda Limestone, Siljan District, Sweden. Geologiska Föreningens i Stockholm Förhandlingar 109: 83-99. http://dx.doi. org/10.1080/11035898709454748

Furnish W.M. \& Glenister B.F. 1964a. Nautiloidea-Ascocerida. In: Teichert C. (ed.) Treatise on Invertebrate Paleontology, Part K, Mollusca 3. K261-K277. Geological Society of America and the University of Kansas Press, Boulder, Colorado.

Furnish W.M. \& Glenister B.F. 1964b. Nautiloidea-Tarphycerida. In: Teichert C. (ed.) Treatise on Invertebrate Paleontology, Part K, Mollusca 3. K343-K368. Geological Society of America and the University of Kansas Press, Boulder, Colorado.

Glynn P.W. \& Enochs I.C. 2011. Invertebrates and their roles in coral reef ecosystems. In: Dubinsky Z. \& Stambler N. (eds) Coral Reefs: An Ecosystem in Transition: 273-325. Springer, New York.

Hall J. 1847. Natural History of New York, Paleontology, Volume 1, containing Descriptions of the Organic Remains of the Lower Division of the New-York System (Equivalent of the Lower Silurian Rocks of Europe). Van Benthuysen, Albany, New York.

Holland C.H. 1993. Nautiloid Cephalopods of the Kildare Limestone (Ashgill), Ireland. Geological Journal 28: 37-44. http://dx.doi.org/10.1002/gj.3350280104

Holland C.H. 2000. Silurian cephalopods from the Pentland Hills. Scottish Journal of Geology 36: 177186. 
Holland C.H. 2002. Cephalopods from a borehole in the type Wenlock area. Proceedings of the Geologists Association 113: 207-215.

Hucke K. \& Voigt E. 1967. Einführung in die Geschiebeforschung (Sedimentärgeschiebe). Nederlandse Geologische Vereniging, Oldenzaal.

Isberg O. 1934. Studien über die Lamellibranchiaten des Leptaenakalkes in Dalarna. Håkan Ohlssons Buchdruckerei, Lund.

Jaanusson V. 1982. Introduction to the Ordovician of Sweden. IV ${ }^{\text {th }}$ International Symposium on the Ordovician System, Field Excursion Guide: 1-9.

Karsten G. 1869. Die Versteinerungen des Uebergangsgebirges in den Geröllen der Herzogthümer Schleswig und Holstein. Beiträge zur Landeskunde der Herzogthümer Schleswig und Holstein, Reihe 1, 1: 1-85.

Kesling R.V. 1961. A new species of Billingsites, an ascoceratid cephalopod, from the Upper Ordovician Ogontz Formation of Michigan. Contributions from the Museum of Paleontology, the University of Michigan 17 (3): 77-121.

Korn D. \& Klug C. 2003. Morphological pathways in the evolution of Early and Middle Devonian ammonoids. Paleobiology 29: 329-348.

Kröger B. 2007. Concentrations of juvenile and small adult cephalopods in the Hirnantian cherts (Late Ordovician) of Porkuni, Estonia. Acta Palaeontologica Polonica 52: 591-608.

Kröger B. \& Isakar M. 2006. Revision of annulated orthoceridan cephalopods of the Baltoscandic Ordovician. Fossil Record 9: 139-165. http://dx.doi.org/10.1002/mmng.200600005

Kröger B., Servais T. \& Zhang Y. 2009. The origin and initial rise of pelagic cephalopods in the Ordovician. PLoS ONE 4 (9): e7262. http://dx.doi.org/10.1371/journal.pone.0007262

Kröger B., Ebbestad J.O.R., Högström A.E.S. \& Frisk Å.M. 2011. Mass concentration of Hirnantian cephalopods from the Siljan District, Sweden; taxonomy, palaeoecology and palaeobiogeographic relationship. Fossil Record 14: 35-53. http://dx.doi.org/10.1002/mmng.201000014

Lindström G. 1890. The Ascoceratidae and the Lituitidae of the Upper Silurian formation of Gotland. Kungliga Svenska Vetenskaps-Akademiens Handlingar 23: 1-54.

Lossen C. 1860. Über einige Lituiten. Zeitschrift der deutschen geologischen Gesellschaft 12: 15-28.

Mutvei H. 1957. On the relations of the principal muscles to the shell in Nautilus and some fossil nautiloids. Arkiv för Mineralogi och Geologi 2: 219-254.

Mutvei H. 2002. Connecting ring structure and its significance for classification of the orthoceratid cephalopods. Acta Palaeontologica Polonica 47 (1): 157-168.

Mutvei H. 2012. Siphuncular structure in Silurian discosorid and ascosorid nautiloids (Cephalopoda) from Gotland, Sweden: implications for interpretation of mode of life and phylogeny. GFF 134: 27-37. http://dx.doi.org/10.1080/11035897.2012.654507

Mutvei H. \& Dunca E. 2011. Siphuncular structure in the orders Tarphycerida and Barrandeocerida (Cephalopoda: Nautiloidea). Palaeontology 54: 705-710. http://dx.doi.org/10.1111/j.1475$\underline{4983.2011 .01041 . x}$

Nathorst A.G. 1885. Några ord om slipsandstenen i Dalarne. Sveriges Geologiska Undersökning, Afhandlingar och Uppsater C 71: 1-26.

Neben W. \& Krueger H.H. 1973. Fossilien ordovizischer und silurischer Geschiebe. Staringia 2: 51-109. 
KRÖGER B., Cephalopods of the Boda Limestone

Niko S. 2008. Isorthoceras wahlenbergi, a new Late Ordovician cephalopod from the Boda Limestone of Dalarna, Sweden. Paleontological Research 12: 195-198. http://dx.doi.org/10.2517/1342$\underline{\text { 8144(2008)12[195:IWANLO]2.0.CO;2 }}$

Plotnick R.E. 1986. Taphonomy of a modern shrimp: Implications for the arthropod fossil record. Palaios 1 (3): 286-293.

Portlock J.E. 1843. Report on the Geology of the County of Londonderry and of parts of Tyrone and Fermanagh. Andrew Milliken, Dublin.

Rasmussen C.M., Ebbestad J.O.R. \& Harper D.A.T. 2010. Unravelling a Late Ordovician pentameride (Brachiopoda) hotspot from the Boda Limestone, Siljan district, central Sweden. GFF 132 (3): 133-152. http://dx.doi.org/10.1080/11035897.2010.506008

Reimold U., Kelley S.P., Sherlock S.C., Henkel H. \& Koeberl C. 2005. Laser argon dating of melt breccias from the Siljan impact structure, Sweden: Implications for a possible relationship to late Devonian extinction events. Meteoritics \& Planetary Science 40: 1-17.

Riding R. 2002. Structure and composition of organic reefs and carbonate mud mounds: concepts and categories. Earth-Science Reviews 58: 163-231. http://dx.doi.org/10.1016/S0012-8252(01)00089-7

Roemer C.F. 1861. Die fossile Fauna der silurischen Diluvial-Geschiebe von Sadewitz bei Oels in Nieder-Schlsien. Breslau.

Roemer C.F. 1885. Lethaea erratica oder Aufzählung und Beschreibung der in der norddeutschen Ebene vorkommenden Diluvialgeschiebe nordischer Sedimentär-Gesteine. Paläontologische Abhandlungen 2: 248-420.

Ruedemann R. 1919. On colour bands in Orthoceras. New York State Museum Bulletin 227-228: 79-88.

Saladzius V. 1966. Mollusc fauna of the Silurian deposits of the South of the East Baltic territory. Paleontology and Stratigraphy of the Baltic and Byelorussia 1: 31-73.

Schmidt F. 1858. Untersuchungen über die Silurische Formation von Ehstland, Nord-Livland und Ösel. Archiv für die Naturkunde Liv-, Ehst- und Kurlands, 1. Serie (Mineralogische Wissenschaften, nebst Chemie, Physik und Erdbeschreibung) 2: 1-248.

Schmidt F. 1861. Nachträge und Berichtigungen zu den Untersuchungen über die Silurische Formation von Ehstland, Nord-Livland und Ösel. Archiv für die Naturkunde Liv-, Ehst- und Kurlands, 1. Serie (Mineralogische Wissenschaften, nebst Chemie, Physik und Erdbeschreibung) 2: 465-474.

Schröder H. 1891. Untersuchungen über silurische Cephalopoden. Palaeontologische Abhandlungen, Neue Folge 1 (4): 1-48.

Strand T. 1934. The Upper Ordovician Cephalopods of the Oslo Area. Norsk Geologiske Tidsskrift 14: $1-117$.

Stumbur H. 1955. Eestin NSV ülem-ordoviitsiumi nautiloiididest. PhD thesis. Tartu Riikliku Ülikooli Matemaatika-loodusteaduskonna geoloogia oskonna üliõpilase 156. Estonia.

Stumbur H. 1956. O nautiloidea Kohilaskogo jarusa (Verhnij Ordovik Pribaltiki). Tartu Riikliku Ülikooli Toimetised 42: 176-185.

Stumbur H. 1962. Rasprostranenie nautiloidei v ordovike Estonii (s opisaniem nekotorykh novykh rodov). ENSV Teaduste Akadeemia Geoloogia Instituudi Uurimused 10: 131-147.

Suzuki Y. 2002. Systematic position and palaeoecology of a cavity-dwelling trilobite, Ityophorus undulatus Warburg, 1925, from the Upper Ordovician Boda Limestone, Sweden. Paleontological Research 6 (1): 73-83. 
Suzuki Y. \& Bergström J. 1999. Trilobite taphonomy and ecology in Upper Ordovician carbonate buildups in Dalarna, Sweden. Lethaia 32: 195-172. http://dx.doi.org/10.1111/j.1502-3931.1999.tb00536.x

Suzuki Y., Shiino Y. \& Bergström J. 2009. Stratigraphy, carbonate facies and trilobite associations in the Hirnantian part of the Boda Limestone, Sweden. GFF 131: 299-310. http://dx.doi. org $/ 10.1080 / 11035890903452670$

Sweet W.C. 1958. The Middle Ordovician of the Oslo region of Norway. 10. Nautiloid cephalopods. Norsk Geologiske Tidsskrift 31: 1-178.

Sweet W.C. 1959. Muscle-Attachment Impressions in Some Paleozoic Nautiloid Cephalopods. Journal of Paleontology 33 (2): 293-304.

Sweet W.C. 1964a. Barrandeocerida. In: Moore R.C. (ed.) Treatise on Invertebrate Paleontology, Part K, Mollusca 3. K368-K382. University of Kansas Press, Boulder, Colorado.

Sweet W.C. 1964b. Oncocerida. In: Moore R.C. (ed.) Treatise on Invertebrate Paleontology, Part K, Mollusca 3. K277-K319. University of Kansas Press, Boulder, Colorado.

Sweet W.C. 1964c. Orthocerida. In: R. C. Moore (ed.) Treatise on Invertebrate Paleontology, Part K, Mollusca 3. K216-K261. University of Kansas Press, Boulder, Colorado.

Teichert C. 1930. Die Cephalopoden-Fauna der Lyckholm-Stufe des Ostbaltikums. Paläontologische Zeitschrift 12: 264-312.

Teichert C. 1964. Endoceratoidea. In: R. C. Moore (ed.) Treatise on Invertebrate Palaeontology, Part K, Mollusca 3. K160-K189. Geological Society of America and the University of Kansas Press, Boulder, Colorado.

Thorslund P. 1935. Über den Brachiopodenschiefer und den jüngeren Riffkalk in Dalarne. Nova Acta Regio Societas Scientiarum Upsaliensis 4: 1-50.

Thorslund P. 1936. Siljanområdets brännkalkstenar och kalkindustri. Sveriges Geologiska Undersökning, Afhandlingar och Uppsater, C 398: 1-57.

Warburg E. 1910. Geological description of Nittsjö and its environs in Dalarne. GFF 32: 425-450.

Warburg E. 1925. The trilobites of the Leptaena limestone in Dalarne with a discussion of the zoological position and the classification of the Trilobita. Bulletin of the Geological Institutions of the University of Uppsala 17: 1-446.

Westermann G.E.G. 1998. Life habits of nautiloids. In: Savazzi E. (ed.) Functional Morphology of the Invertebrate Skeleton: 263-298. John Wiley \& Sons, Chichester, New York.

Manuscript received: 10 May 2012

Manuscript accepted: 21 December 2012

Published on: 27 March 2013

Topic editor: Christian de Muizon

Desk editor: Danny Eibye-Jacobsen

Printed versions of all papers are also deposited in the libraries of the institutes that are members of the EJT consortium: Muséum National d'Histoire Naturelle, Paris, France; National Botanic Garden of Belgium, Meise, Belgium; Royal Museum for Central Africa, Tervuren, Belgium; Natural History Museum, London, United Kingdom; Royal Belgian Institute of Natural Sciences, Brussels, Belgium; Natural History Museum of Denmark, Copenhagen, Denmark. 